Thales Cavalcanti Coelho

\title{
LIVRE-ARBÍTRIO E CULPABILIDADE: A RESPONSABILIZAÇÃO PENAL EM FACE DAS CONTRIBUIÇÕES DA NEUROCIÊNCIA
}

\author{
DisSERTAÇÃO DE MESTRAdO
}

ORIENTADOR: Prof. Dr. Víctor GABRIEL DE OlIVEIRA RodRÍGUEZ

UNIVERSIDADE DE SÃo PAULO

FACULDADE DE DIREITO

SÃo PAULO/SP

2015 
Thales Cavalcanti CoElHo

\title{
LIVRE-ARBÍTRIO E CULPABILIDADE: A RESPONSABILIZAÇÃO PENAL EM FACE DAS CONTRIBUIÇÕES DA NEUROCIÊNCIA
}

\author{
Dissertação apresentada à Banca \\ Examinadora do Programa de Pós- \\ Graduação Stricto Sensu da Faculdade de \\ Direito da Universidade de São Paulo, \\ como requisito parcial para a obtenção do \\ título de Mestre em Direito na área de \\ concentração Direito Penal, Medicina \\ Forense e Criminologia, sob orientação do \\ Prof. Dr. Víctor Gabriel de Oliveira \\ Rodríguez.
}

UNIVERSIDADE DE SÃo PAULO

FACULDADE DE DIREITO

SÃO PAULO/SP 
Thales CAVAlCANTi CoElHo

\title{
LIVRE-ARBÍTRIO E CULPABILIDADE: A RESPONSABILIZAÇÃO PENAL EM FACE DAS CONTRIBUIÇÕES DA NEUROCIÊNCIA
}

\author{
Dissertação apresentada à Banca \\ Examinadora do Programa de Pós- \\ Graduação Stricto Sensu da Faculdade de \\ Direito da Universidade de São Paulo, \\ como requisito parcial para a obtenção do \\ título de Mestre em Direito na área de \\ concentração Direito Penal, Medicina \\ Forense e Criminologia, sob orientação do \\ Prof. Dr. Víctor Gabriel de Oliveira \\ Rodríguez.
}

BANCA EXAMINADORA:

Prof. Dr. VÍCTOR GABRIEL DE OlIVEIRA RODRÍGUEZ PROF. DR.

PROF. DR. 


\section{Catalogação da Publicação}

Serviço de Biblioteca e Documentação

Faculdade de Direito da Universidade de São Paulo

Coelho, Thales Cavalcanti

Livre-arbítrio e culpabilidade: a responsabilização penal em face das contribuições da neurociência / Thales Cavalcanti Coelho ; orientador Víctor Gabriel de Oliveira Rodríguez - - São Paulo, 2015.

$232 \mathrm{f}$.

Dissertação (Mestrado - Programa de Pós-Graduação em Direito Penal, Medicina Forense e Criminologia) - Faculdade de Direito, Universidade de São Paulo, 2015.

1. Culpabilidade. 2. Livre-arbítrio. 3. Neurociência. 4. Neurodireito. 5. Punição. I. Rodríguez, Víctor Gabriel de Oliveira, orient. II. Título. 
Aos meus pais Jonas e Cida, com gratidão.

Aos meus irmãos Thomas e Sophia, com carinho.

À Bárbara, com amor. 


\section{AgradeCimentos}

A presente dissertação, resultado de dois anos e meio de intenso trabalho de pesquisa, não existiria sem a generosidade e a paciência de algumas pessoas, de quem guardo profunda gratidão e a quem dirijo singelos agradecimentos.

Ao orientador desta monografia, Professor Doutor Víctor Gabriel Rodríguez, mentor acadêmico deste autor desde a graduação, por, mais do que depositar em mim a confiança de ser um de seus primeiros orientados de pós-graduação, dispensar algo de sua inesgotável prestatividade para analisar e corrigir cada linha deste trabalho em meio à elaboração e à defesa de sua tese de livre-docência.

Ao Professor Doutor Jonas Gonçalves Coelho, pai, pela instigante sugestão do tema de pesquisa e pelo desvelo com que me guiou no percurso de investigação em torno das questões atinentes à filosofia da mente e às neurociências, disciplinas de conteúdo desafiador frente à minha formação de Bacharel em Direito.

Ao querido amigo Gustavo de Carvalho Marin, parceiro de inúmeras empreitadas acadêmicas na seara penal, por ter compartilhado comigo não apenas seu extraordinário acervo bibliográfico (que se revelou como imprescindível material de pesquisa para o presente estudo), como seu escasso tempo de dedicado advogado e incansável pesquisador para sempre proveitosas trocas de ideia.

Ao Doutor César Augusto Moreira, por permitir, mais uma vez, com inexaurível compreensão e abnegação, que eu recorrentemente me ausentasse do escritório de advocacia para me voltar, com a dedicação necessária, à elaboração desta dissertação.

Aos professores do programa de pós-graduação da Faculdade de Direito da Universidade de São Paulo, por me proporcionarem, com criticidade, uma visão global do sistema jurídico-penal, imprescindível às pretensões científicas de um penalista iniciante.

Aos mantenedores, colaboradores e funcionários da Biblioteca do Instituto Brasileiro de Ciências Criminais, pela qualidade do serviço de disponibilização de suas obras, sem as quais a produção deste trabalho seria inviável.

À Bárbara Bittar Teixeira pelo apoio incondicional e incentivo diário, e pela paciência com que suporta as alterações de humor decorrentes das (não tão raras) frustrações de um recém-graduado. À sua família, por me terem como um dos seus.

Aos meus pais e meus irmãos, por tornarem mais esta empreitada possível, e por suportarem minha persistente ausência com a compreensividade de quem só quer o bem. 
"If our brains were simple enough for us to understand them, we'd be so simple that we couldn't."

("Se nosso cérebro fosse simples o bastante para ser compreendido, não seríamos inteligentes o bastante para compreendê-lo.")

Jack Cohen e Ian Stewart (The collapse of chaos: discovering simplicity in a complex world, p. 8). 


\section{RESUMO}

CoelHo, Thales Cavalcanti. Livre-arbítrio e culpabilidade: a responsabilização penal em face das contribuições da neurociência. Junho de 2015. 232 p. Dissertação de Mestrado. Faculdade de Direito, Universidade de São Paulo. São Paulo, 2015.

O presente estudo tem por objetivo analisar as implicações, na estrutura de imputação penal, das recentes pesquisas em neurociência voltadas a investigar os processos de formação da vontade no cérebro humano. Considerando-se que, dos resultados de experimentos acerca do funcionamento do sistema nervoso central, alguns pesquisadores têm interpretado que as condutas humanas são desencadeadas a partir de processos determinísticos, e não originadas da vontade livre do indivíduo, busca-se verificar de que maneira tais conclusões impactam a responsabilidade penal, notadamente no que diz respeito à culpabilidade, uma vez que sua concepção tradicional e consolidada está fundamentada fortemente na ideia de livre-arbítrio. Com esse escopo, valendo-se do método teórico-bibliográfico, o trabalho se desenvolve em três grandes etapas. Assim, primeiramente, visa-se compreender a relação entre culpabilidade e livre-arbítrio, inicialmente expondo-se de que maneira o primeiro conceito arrogou o segundo como pressuposto no decorrer de seu desenvolvimento epistemológico, para tornar possível, depois de realizada uma análise das razões da consolidação - e da posterior crise - de sua concepção normativa no pensamento penal, examinar quais são (e se são firmes e coerentes) as alternativas teóricas a esse conceito apresentadas pela doutrina contemporânea. Em seguida, volta-se ao estudo da relação entre livre-arbítrio e neurociências. Nessa etapa, investiga-se a natureza dos argumentos utilizados pelos penalistas tanto para sustentar, quanto para refutar a ancoragem da responsabilização penal no livre-arbítrio, examinando-se, ainda, eventuais fragilidades e inconsistências, além dos possíveis aportes que as pesquisas em neurociência podem lhes proporcionar. Tudo isso, com o intuito de se verificar se o advento da neurociência representa uma mudança de paradigma na polêmica em torno da liberdade de vontade. Na fase final do trabalho, o estudo é orientado a traçar um esboço do futuro da responsabilização penal em face dos aportes da neurociência, analisando-se se representam (ou não) o fim da culpabilidade na estrutura de imputação e, além disso, qual o modelo de punição mais adequado - tendo-se como parâmetro as finalidades da pena - aos postulados neurocientíficos.

Palavras-chave: culpabilidade; livre-arbítrio; neurociência; neurodireito; punição. 


\begin{abstract}
Coelho, Thales Cavalcanti. Free will and culpability: the criminal liability in light of the contributions of neuroscience. June of 2015. 232 p. Master's thesis. Faculty of Law, University of São Paulo. São Paulo, 2015.

The goal of this study is to analyze the implications on criminal liability of the recent researches in the field of neuroscience that relates to will-formation in human brains. Taking into account that some researchers have interpreted, based on experiments about the functioning of the central nervous system, that human behavior become from deterministic processes, instead of the free will of the person, we aim to verify in what ways those conclusions affects the criminal liability. The focus of the review is on criminal culpability, whose traditional concept is based on the idea of free will. With three major portions, the thesis is developed by the bibliographic method. At first, the target is to understand the relationship between criminal culpability and free will and how that one is grounded on this one. Then, after the analysis of the reasons of the consolidation, and subsequent crisis, of the normative concept of culpability among the criminal authors, the purpose is to assay the theoretic alternatives to this notion that are provide by the contemporary doctrine. After that, the work follows with the study of the relationship between free will and neuroscience. At this stage, we investigate the nature of the arguments used by criminalists both to support and to refute the anchor of the criminal liability in free will. We also examine possible weaknesses and inconsistencies, as well as likely contributions that research in neuroscience can provide them. All this in order to verify if the advent of neuroscience represents a paradigm shift in the controversy surrounding free will. In the final phase of the work, there is the attempt to draw a sketch of the future of criminal responsibility in light of the contributions of neuroscience. Thus, we analyze whether these represent (or not) the end of culpability in the structure of criminal liability and what is the most appropriate punishment model to neuroscientific postulates, taking as parameter the purposes of the penalty.
\end{abstract}

Keywords: culpability; free will; neuroscience; neurolaw; punishment. 


\section{SUMÁRIO}

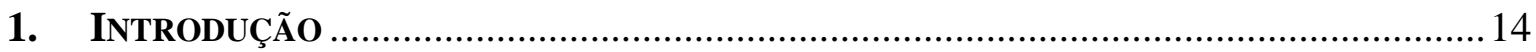

2. Prólogo: a Abertura do Sistema de direito penal aOS APORTes da

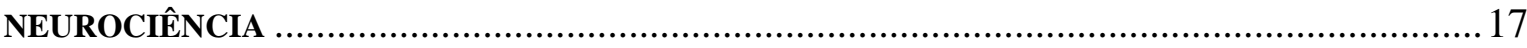

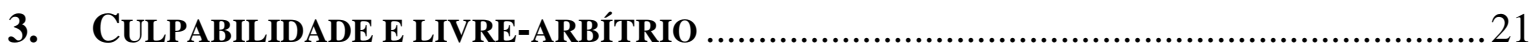

3.1. Considerações introdutórias: a culpabilidade como elemento do crime e sua

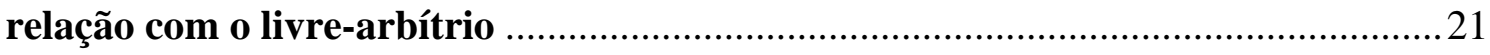

3.2. Antecedentes das modernas teorias da culpabilidade................................... 22

3.3. Desenvolvimento epistemológico da culpabilidade .....................................25

3.3.1. O positivismo naturalista e a concepção psicológica da culpabilidade ..........25

3.3.2. O positivismo normativista e a concepção psicológico-normativa da

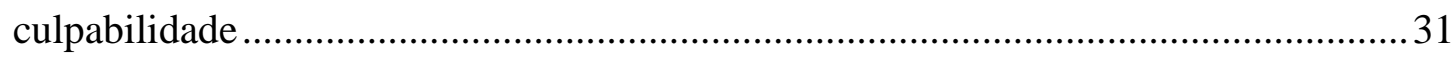

3.3.3. O finalismo e a concepção normativa pura da culpabilidade ........................ 41

3.4. A crise do conceito de culpabilidade normativa ...........................................50

3.5. Panorama atual: alternativas teóricas à culpabilidade normativa.................55

3.5.1. Responsabilização penal sem culpabilidade: posições negacionistas.............55

3.5.1.1. Determinismo e a responsabilização penal fundada na defesa social por meio da pena: os percussores Enrico FERRI e Pedro LESSA .......................................56

3.5.1.2. Afastamento do debate acerca do livre-arbítrio e a responsabilização penal fundada na prevenção por meio da pena: Enrique GIMBERNAT ORDEIG.

3.5.2. Responsabilização penal com culpabilidade: propostas de um novo substrato material determinado a partir de critérios extrínsecos

3.5.2.1. Culpabilidade como um déficit de fidelidade ao ordenamento jurídico em Günther JAKOBS

3.5.2.2. Culpabilidade como um déficit de fidelidade ao ordenamento jurídico em Urs KINDHÄUSER 
3.5.3. Responsabilização penal com culpabilidade: propostas de uma determinação revisada da culpabilidade a partir de critérios intrínsecos

3.5.3.1. SCHÜNEMANN e a concepção indeterminista da culpabilidade em um Direito como realidade socialmente criada

3.5.3.2. HASSEMER e a culpabilidade sem reprovação 75

3.5.3.3. MUÑOZ CONDE e a concepção dialética da culpabilidade 77

3.5.3.4. ZAFFARONI e a culpabilidade por vulnerabilidade. 78

3.5.4. Responsabilização penal com culpabilidade: a posição integradora de RoXIN 81

3.6. Considerações finais: indefinição a respeito do conteúdo da culpabilidade (dependência ou independência da ideia de livre-arbítrio). 84

4. LIVRE-ARBÍTRIO E NEUROCIÊNCIAS 89

4.1. Considerações introdutórias: o livre-arbítrio como problema filosófico e a contribuição das ciências naturais.

4.2. Fundamentos filosóficos e científicos do pensamento penal baseado na afirmação do livre-arbítrio

4.2.1. Possibilidade de liberação causal dos impulsos (autocontrole): WELZEL ......91

4.2.1.1. Aportes da neurociência à questão do autocontrole ................................. 103

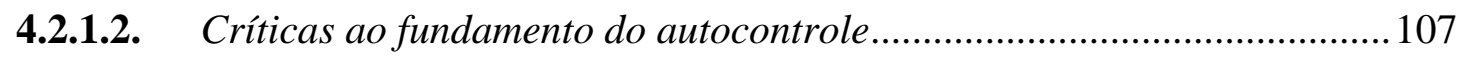

4.2.2. Experiência subjetiva de possibilidade de eleição de condutas: SCHÜNEMANN 113

4.2.2.1. Aportes da neurociência à questão da experiência subjetiva 115

4.2.2.2. Críticas ao fundamento da experiência subjetiva.

4.3. Fundamentos filosóficos e científicos do pensamento penal não baseado na afirmação do livre-arbítrio

4.3.1. Indemonstrabilidade empírica do livre-arbítrio: ROXIN, KINDHÄUSER e outros 124

4.3.1.1. Aportes da neurociência à questão da indemonstrabilidade empírica.... 125 
4.3.1.2. Críticas ao fundamento da indemonstrabilidade empírica

4.3.2. Comportamento criminoso, normalidade cognitiva e motivação pela norma: JAKOBS 131

4.3.2.1. Aportes da neurociência à questão da motivação normal do agente ....... 132

4.3.2.2. Críticas ao fundamento da motivação normal do agente 135

4.4. A contribuição da neurociência ao problema do livre-arbítrio: uma mudança de paradigma?

4.5. Considerações finais: uma certeza e muitas dúvidas pelo caminho 144

5. NEUROCIÊNCIAS E CULPABILIDADE 148

5.1. Considerações introdutórias: a neurociência como realidade nos tribunais (investigação do cérebro e aferição da imputabilidade do agente) 148

5.2. A hipótese da transgressão penal enquanto indício de anormalidade cerebral: discussões acerca da posição da imputabilidade na estrutura de imputação e da intervenção cerebral como resposta estatal ao delito 151

5.3. O futuro da atribuição de responsabilidade penal ante os aportes da neurociência.

5.3.1. O fim da culpabilidade?

5.3.2. Comportamento violento e perigosidade: fiéis da balança na emergência de um modelo preventivo de responsabilização penal?

5.4. Análise da adequação entre as propostas alternativas à culpabilidade normativa e os postulados neurocientíficos 188

5.4.1. A proposta de Bernd SCHÜNEMANN 190

5.4.2. A proposta de Claus RoxIN 193

5.4.3. A proposta de Günther JАKOBS 195

5.4.4. A proposta de Winfried HASSEMER 198

5.5. Considerações finais: conhecimentos consolidados da neurociência no presente e perspectivas teóricas para o futuro da culpabilidade. 200

6. EPÍlOGO: O ESTUDO DO CÉREBRO E O FUTURO DO DIREITO PENAL 205 


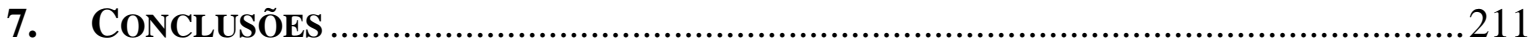

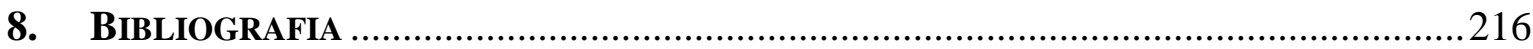




\section{INTRODUÇÃo}

O vertiginoso desenvolvimento dos campos da tecnologia e das ciências médicas tem contribuído sobremaneira, especialmente nos últimos trinta anos, para a compreensão dos mecanismos de funcionamento do cérebro humano. Com efeito, a evolução das técnicas de leitura da atividade cerebral tem permitido aos pesquisadores não só observar a estrutura anatômica do sistema nervoso central, como também examinar os processos que ali se realizam. Assim, a partir de experimentos levados a efeito com a utilização de procedimentos de escaneamento encefálico, por exemplo, muitas vezes registrando as atividades neuronais em tempo real, os neurocientistas têm logrado vasculhar os mecanismos cerebrais subjacentes às funções cognitivas, vale dizer, às atividades mentais relacionadas ao tratamento das informações (percepção, memória, raciocínio etc.).

Nesse contexto, por sua relevância nas mais diversas áreas do conhecimento filosofia, psicologia, economia, direito etc. -, têm recebido particular destaque na comunidade científica os estudos voltados à investigação dos processos de tomada de decisão e de formação da vontade no cérebro humano. A atenção despendida pelos neurocientistas nesse assunto se deve, em grande medida, à busca de quais são - e como agem - os fatores responsáveis pela constituição do comportamento do indivíduo. Expressamente, partindo da assunção de que a atividade cerebral se realiza por meio de processos determinísticos - vale dizer, por relações de causa e efeito -, os pesquisadores têm procurado identificar quais os componentes por detrás das mais variadas condutas humanas.

$\mathrm{Na}$ esteira da investigação das origens e das causas do comportamento, uma parcela significativa de neurocientistas tem proposto, com base tanto no conhecimento sistêmico do funcionamento do cérebro humano, quanto no resultado de experimentos voltados a testar diretamente o livre-arbítrio, que a formação da vontade em cada indivíduo não se dá de forma livre, e que ocorre precipuamente de modo inconsciente. A ideia defendida por esses pesquisadores é a de que, conquanto complexo e difícil de prever, o processo de tomada de decisão é desencadeado a partir de uma interação calculável entre fatores determináveis, a qual apenas emerge à consciência, proporcionando a experiência subjetiva de liberdade de vontade, quando, em verdade, as escolhas já teriam sido realizadas pelo cérebro - de maneira "automática" e "pré-determinada". 
Essa tese, apesar de não ser consenso (nem majoritária, quiçá) na comunidade científica, por sua pretensão revolucionária e seu aparente respaldo empírico, depois de ganhar força no âmbito da neurociência, passou a impactar outros campos do saber, notadamente a filosofia, que há séculos tem cuidado da questão do livre-arbítrio e da responsabilidade moral, sem lograr, contudo, atingir uma conclusão representativa de um entendimento assente. Nessa linha, um respeitado grupo de pesquisadores de todo o mundo tem propalado que advento das modernas pesquisas em neurociência apontam para mudanças significativas no que diz respeito à percepção subjetiva, socialmente consolidada, de que a liberdade de vontade é inerente ao ser humano. Assim, a título de exemplo, segundo manifesto publicado na Alemanha, em 2004, por onze neurocientistas dos mais importantes centros de pesquisa daquele país, a investigação cerebral, em um período de tempo previsível - no próximos vinte ou trinta anos - poderá alcançar a conexão entre processos neuroelétricos e neuroquímicos, assim como funções perceptivas, cognoscitivas, psíquicas e motoras, até o ponto em que será possível fazer predições bastante certeiras sobre estas conexões - tornando viável, verbi gratia, prognósticos de comportamento (MONYER; RÖSLER; ROTH; SCHEICH et al., 2004). Para esses autores, isso significa que devemos contemplar a mente, a consciência, os sentimentos, os atos voluntários e a liberdade de ação como processos naturais, por todos basearem-se em mecanismos biológicos.

As repercussões dessa presciência no campo do direito penal parecem evidentes, já que as conclusões da neurociência, uma vez confirmadas, fariam ruir em grande medida o arcabouço teórico que sustenta a ciência do direito penal contemporâneo. E, naturalmente, o elemento mais sensível a aportes neurocientíficos daquele jaez é a culpabilidade, posto que, ao menos em sua concepção tradicional e consolidada - a normativa, com os aportes finalistas de Hans WELZEL -, adotada em vários sistemas jurídicos ocidentais, dentre os quais o brasileiro, somente tem sentido a partir da ideia de existência do livre-arbítrio. Caracterizada formalmente pela "reprovabilidade" do fato ao sujeito, vale dizer, pela possibilidade de se dirigir a um indivíduo uma reprovação individual por sua ação, a partir de valorações e critérios normativos, a culpabilidade welzeliana tem como conteúdo material o "poder atuar de outro modo", noção largamente ancorada na premissa de que o ser humano tem como uma de suas aptidões a liberdade de vontade.

Diante desse quadro, a proposta do trabalho é a de analisar como os aportes dos recentes estudos em neurociência impactam a noção de culpabilidade. Especificamente, 
examinar se em face do atual estágio de desenvolvimento das investigações sobre o cérebro, bem como dos prognósticos dos neurocientistas, ainda se justifica a manutenção do conceito atual de culpabilidade - ou, até mesmo, se faz sentido a própria conservação da culpabilidade na estrutura do delito. Para tanto, trabalhar-se-á, em um primeiro momento, a relação entre responsabilidade penal e livre-arbítrio, investigando como, de um modo geral, os doutrinadores penais trataram a questão no contexto do desenvolvimento epistemológico da culpabilidade, e em seus antecedentes históricos. Em uma etapa posterior, pretende-se desenvolver um panorama crítico de como os fundamentos filosóficos e científicos de sustentação e de refutação da liberdade de vontade na estrutura de responsabilização penal foram trabalhados pelo pensamento penal, o que será feito a partir da perspectiva das principais correntes teóricas acerca do livre-arbítrio (determinismo, libertarismo e compatibilismo), verificando-se, ainda, as repercussões da abordagem contemporânea da neurociência na discussão. E, por fim, com base nas conclusões da etapa anterior, buscar-se-á analisar, de um modo geral, os reflexos, na ciência penal, das contribuições neurocientíficas à discussão em torno do livre-arbítrio.

A hipótese de partida da pesquisa é a de que, mesmo que não seja possível aferir cabalmente, em um futuro próximo, a existência da liberdade de vontade, os subsídios trazidos pela neurociência do comportamento agregam novos elementos para a compreensão da ação humana, apontando para a substituição da noção tradicional de culpabilidade (que, aliás, há tempos já é criticada) por uma nova proposta, mais estreitamente ligada às finalidades preventivas da pena - inclusive as de prevenção especial, voltadas à recuperação do autor do injusto penal (via, até mesmo, intervenção cerebral direta e indireta). Sustentada a hipótese ao longo do trabalho - isto é, da necessidade de um aperfeiçoamento do conceito de culpabilidade ou, até mesmo, de seu afastamento da estrutura de imputação -, estudar-se-á se as teses funcionalistas alternativas à culpabilidade finalista se mostram adequadas a essa nova realidade, bem ainda se as propostas formuladas pelos neurocientistas podem ser aproveitadas, em algum grau, na edificação desse novo modelo. 


\section{Prólogo: a Abertura do Sistema de direito Penal aOS APORTES da NEUROCIÊNCIA}

A história da ciência é, segundo Thomas S. KuHn (1978, pp. 125 a 144), o retrato documentado do progresso dos conhecimentos que o ser humano tem sobre a natureza que o cerca e da qual faz parte, e que não provém de uma acumulação linear de descobertas, mas de uma série de revoluções científicas, isto é, de episódios de desenvolvimento não cumulativo do saber, nos quais, em um contexto de crise, um paradigma ${ }^{1}$ mais antigo é total ou parcialmente substituído por um novo, incompatível com o anterior. Considerando que um dos objetivos da teoria científica é encontrar modelos que compreendam a maior quantidade de observações dentro de um marco coerente, e tendo em conta que ainda não foi desenvolvida uma teoria de tudo - vale dizer, capaz de explicar, de maneira íntegra e unificada, todos os fenômenos presentes no universo -, nada mais natural que o processo de evolução do conhecimento científico, ainda em curso, continue proporcionando revoluções, notadamente na quadra histórica atual, em que a tecnologia disponível é aprimorada em ritmo exponencial.

Nesse contexto, em que as ciências da natureza experimentam seguidas alterações de paradigma e que as ciências humanas e sociais, por consequência, passam por indefectíveis revisões de seus conceitos, princípios e proposições, o direito penal, conforme observa Cláudio do Prado AMARAL (2007, p. 23), enquanto ramo do conhecimento jurídico, parece por vezes alijado desse movimento. Como consequência notável desta postura em grande medida hermética e autopoiética, observa-se um afastamento daquilo que é seu referencial por excelência: a sociedade de sua época. E, ao distanciar-se da realidade natural e social à qual é referenciado, o direito penal perde sua força enquanto instrumento de controle e de pacificação social, pois deixa de ter legitimidade, já que o poder legítimo depende do consenso dos governados, por fluir da capacidade humana de agir em conjunto.

Para que, contrariamente a essa trilha, o direito penal seja algo aceito e absorvido socialmente, revestindo de legitimidade sua intervenção na esfera de garantias individuais especialmente a liberdade de locomoção -, deve estar em consonância com a realidade da qual faz parte. Isso implica a compreensão de sua dogmática como um processo vivo,

\footnotetext{
${ }^{1}$ Na definição de KUHN (1978, p. 13), paradigmas são as realizações científicas universalmente reconhecidas que, durante algum tempo, fornecem problemas e soluções modelares para uma comunidade de praticantes de uma ciência.
} 
suscetível a adequações demandadas pela sociedade à qual é voltada. Todavia, para que represente um traço democrático, e não arbitrário, da dogmática penal, tal possibilidade de receber aportes de outros componentes da realidade social deve estar criteriosamente estruturada. E, nesse sentido, a delimitação dessa necessária abertura do direito penal passa, inicialmente, por compreendê-lo como um sistema científico.

Conforme assinala Antonio Luís Chaves CAMARgo (2001, pp. 17 a 21), o direito penal, como instrumento de controle social, exige uma base sistemática, a fim de que não se limite a uma exposição pura e simples da legislação penal e de suas consequências para a sociedade. A solução dos conflitos sociais pelo direito penal, segundo o autor, só é possível por meio de uma construção sistemática de seus postulados, apta a promover uma orientação das contradições e um encaminhamento dos problemas ao contexto social.

A análise do professor de São Paulo tem como ponto de partida a definição de sistema apresentada por Claus-Wilhelm CANARIS (1989, pp. 9 a 23), quem conceitua tal noção como a ordenação lógica dos conhecimentos alcançados em uma determinada ciência e considerados conjuntamente. Desde tal concepção, aparecem como traços característicos da ideia de sistema a ordenação e a unidade de conhecimentos. Por meio da primeira, segundo o autor, objetiva-se exprimir um estado de coisas fundado na realidade, vale dizer, intrínseco àquelas e apreensível dessa; com relação à segunda, representa o fator que modifica o próprio resultado da ordenação, ao evitar a dispersão de uma pluralidade de singularidades desconexas, conduzindo os elementos a certos princípios fundamentais.

A construção sistemática, na proposição de CANARIS, revela-se como fator imprescindível para a caracterização de um conjunto de conhecimentos singulares como ciência. Assim, essa só se constitui quando aqueles, cotejados entre si, apresentam coerência e compatibilidade lógica. Nessa linha, o Direito, ao pretender uma aplicação ordenada e unificada de seus preceitos, demanda uma construção sistemática. E, uma vez orientada por certos princípios gerais, como a igualdade e a justiça, tal formulação coloca o Direito como um sistema de caráter teleológico ou axiológico. Na visão do jurista alemão, sendo o ordenamento do sistema jurídico uma entidade conforme a sua derivação da regra de justiça - de natureza valorativa, portanto -, assim também será o sistema correspondente a essa derivação; ou seja, deverá ser uma ordenação axiológica ou teleológica, na qual o teleológico não é compreendido como mera vinculação de meios aos fins, mas em sentido mais amplo, isto é, da realização de valores e de finalidades (CANARIS, 1989, pp. 66 a 76). 
A mera compreensão do Direito - e do direito penal, por consequência - como um sistema, entretanto, não basta para que esteja em consonância com a realidade em constante movimento ao seu redor, fértil em oferecer novas descobertas sobre a natureza e em proporcionar frequentes alterações de usos e costumes. Para alcançar suas finalidades pragmáticas - como a realização da justiça, de um modo geral, e a proteção de bens jurídicos e a estabilização das expectativas normativas, especificamente - o sistema jurídico-penal deve estar em harmonia com a dinâmica social à qual é referido, o que só é possível se houver uma abertura a atualizações epistemológicas. Do contrário, haveria um indesejável engessamento do direito penal, que o tornaria incompatível com a realidade à qual é voltado, perdendo legitimidade perante a sociedade, e tornando-se, assim, incapaz de atingir seus fins.

Essa necessária afirmação do direito penal como um sistema aberto se dá, então, a partir de duas perspectivas: a científica e a objetiva. Objetivamente, a abertura do sistema resulta da essência do objeto do direito penal positivado, vale dizer, da compreensão do direito penal como um fenômeno histórico e, portanto, mutável. Dessa característica substancial se extrai uma particularidade do direito (e do direito penal) em relação às demais ciências: enquanto uma unidade de sentido duradouramente modificável, a ciência penal jamais é capaz de alcançar um desfecho, por se tratar, no âmago, de um processo infindável, na medida em que a história está em permanente construção. Desde o ponto de vista científico, por sua vez, o sistema aberto de direito penal reconhece a incompletude e a provisoriedade do conhecimento ofertado pela ciência. Dessa maneira, o penalista - assim como todo jurista - deve estar preparado para lidar com o sistema até então elaborado de modo a alargá-lo e modificá-lo, desenvolvendo-o, sempre que necessário. Como todo sistema, o direito penal é tão somente um projeto, uma vez que é capaz de exprimir apenas o estado dos conhecimentos de seu tempo. Dessa compreensão resulta que o sistema jurídico-penal não será definitivo - e, tampouco, fechado - enquanto ainda for possível uma reelaboração científica e um progresso do domínio em causa (CANARIS, 1989, pp. 103 a 112; CAmargo, 2001, pp. 25 a 28; Amaral, 2007, pp. 40 a 42).

A tarefa de um direito penal enquanto sistema aberto é a de exprimir o quadro geral de todos os conhecimentos disponíveis até o presente, garantindo uma concatenação lógica e coerente entre eles. Sua função, portanto, não é a de modificar a ciência, mas de adaptarse a ela, conformando uma unidade de sentido dinâmica, própria de sua característica de construção histórica. A abertura como reconhecimento da incompletude do conhecimento 
científico do direito penal significa, ademais, uma possibilidade de modificação e de revisão da própria ordem jurídica, na medida em que a realidade social demandar - o que pode ocorrer, por exemplo, quando uma revolução científica fizer ruir determinados fundamentos da dogmática jurídico-penal. E é uma ameaça dessa natureza que têm propagado alguns autores em relação ao advento da neurociência.

Com efeito, o rápido e intenso crescimento do campo da neurociência cognitiva sustenta a promessa de explicar as operações da mente no nível físico do funcionamento cerebral. Nesse âmbito, conforme se analisará pormenorizadamente no desenvolvimento do trabalho, já há proposições lastreadas em resultados de experimentos neurocientíficos que colocam em xeque a ideia de livre-arbítrio, sob o argumento de que a tomada de decisão no cérebro humano se dá a partir de processos determinísticos e que a liberdade de vontade constituiria mera ilusão dos sentidos, fabricada pela mente consciente. Se tal tese tem respaldo empírico suficiente para ser compreendida como um conhecimento científico "definitivo" (ou pelo menos seguro) e se representa (ou não) um novo paradigma da ciência, são questões que serão examinadas na sequência da monografia. Todavia, desde já convém assentar que as respostas a tais questionamentos serão buscadas - e toda a investigação objeto desta obra será realizada - a partir do marco teórico adotado, vale dizer, da concepção do direito penal enquanto sistema aberto. Somente desde essa perspectiva se torna viável, e faz sentido, analisar o impacto, na estrutura de responsabilização penal especialmente, na culpabilidade -, dos aportes fornecido pela neurociência ao problema do livre-arbítrio. 


\section{CulPabilidade e LiVRe-ARbítrio}

\subsection{Considerações introdutórias: a culpabilidade como elemento do crime e sua relação com o livre-arbítrio}

Desde que o pensamento sistemático se consolidou na dogmática jurídico-penal, a atribuição de responsabilidade penal é entendida como um processo valorativo escalonado de imputação. Assim, partindo de uma classificação que se firmou como tradicional na teoria do delito, reputa-se criminoso um comportamento humano quando esse reunir determinadas características (degraus de valoração), a saber: a tipicidade, a antijuridicidade e a culpabilidade.

A culpabilidade, enquanto categoria sistemática do delito, é fruto da evolução da dogmática jurídico-penal, tendo experimentado notável desenvolvimento em seu conceito, conteúdo e caracterização a partir do século XIX (LuZÓN PEÑA, 2012, p. 5). Dessa evolução, logrou-se alcançar uma definição corrente na doutrina penal, brasileira e estrangeira, que pode ser resumida da seguinte maneira: a culpabilidade é um juízo de reprovação pessoal, feito a um autor de um fato típico e antijurídico, porque, podendo se comportar conforme o direito, optou por afrontá-lo² (BRANDÃO, 2004, p. 171).

A particular diferença entre a culpabilidade e os demais elementos do delito é que aquela é a única que é voltada à pessoa: enquanto a tipicidade e a antijuridicidade são juízos acerca da conduta, a culpabilidade é um juízo sobre seu autor (BRANDÃO, 2004, pp. 171 e 172). E com o estabelecimento do sujeito como figura central do processo de atribuição de responsabilidade penal, revelou-se necessário, paralelamente ao delineamento de uma estrutura própria da culpabilidade, buscar uma conceituação de pessoa que lhe fosse compatível; ou, de maneira mais precisa, identificar traços comuns que, de um lado, permitissem que os indivíduos se reconhecessem entre si como tal, e de outro, pudessem justificar um juízo de reprovação sobre aqueles que praticam ilícitos penais.

É nesse contexto que aparece a estreita relação entre a culpabilidade e o livrearbítrio: a consideração da culpabilidade como a censura dirigida ao autor de um injusto por não ter se comportado conforme o direito, quando podia ter agido com respeito ao ordenamento jurídico, pressupõe uma liberdade de vontade e de ação desse indivíduo,

\footnotetext{
${ }^{2}$ A origem desta noção encontra-se na dogmática penal alemã, cujas formulações influenciaram - e ainda influenciam - grande parte dos sistemas normativos do mundo ocidental.
} 
ainda que mínima, anterior e simultânea ao fato. O livre-arbítrio apresenta-se, pois, como premissa da culpabilidade e, mais do que isso, como fundamento da pena - ao menos desde a perspectiva de algumas de suas finalidades, vale dizer, a retribuição e a prevenção geral (negativa e positiva).

Em outras palavras, verifica-se que a culpabilidade, ao menos tal qual estruturada atualmente, tem como pressuposto lógico a liberdade de decisão da pessoa, pois apenas quando existe verdadeiramente a capacidade de determinação conforme as normas jurídicas o autor pode ser considerado responsável por ter praticado o fato típico e antijurídico, em vez de reprimir seus impulsos criminais (JESCHECK, 2002, p. 437).

A despeito da prevalência, no atual estágio de desenvolvimento da dogmática penal, da concepção ora apresentada acerca do que se convencionou denominar culpabilidade, sua definição, seus fundamentos e sua missão no âmbito da teoria do crime não são consenso na doutrina. Com efeito, a discussão iniciada com a edificação dessa noção e sua elevação à condição de elemento do delito ainda se mantém viva, com reflexos não apenas na delimitação de responsabilidade penal individual e subjetiva, como também na própria investigação sobre os fundamentos e finalidades da pena.

Motivadora, em grande medida, de mencionada divergência de concepções é a polêmica que envolve a liberdade de decisão e atuação como fundamento da culpabilidade, de modo que tem acompanhado o desenvolvimento histórico das distintas noções acerca desse elemento do delito a discussão sobre a existência de livre-arbítrio no agir humano.

\subsection{Antecedentes das modernas teorias da culpabilidade}

O desenvolvimento epistemológico da culpabilidade, e a consequente discussão acerca seu fundamento material, tem início com a ascensão da construção liberal de Cesare BECCARIA $^{3}$, a partir da qual a própria dogmática jurídico-penal começou a ser delineada.

\footnotetext{
${ }^{3}$ Juan Bustos RAMíREZ (2005, pp. 119 a 122) anota que a despeito de o direito penal, as leis penais e os trabalhos monográficos sobre o delito e a pena serem, inquestionavelmente, antigos, as origens reais do pensamento jurídico-penal atual, com suas pretensões científicas e de sistema, remontam ao Iluminismo, e em especial a BECCARIA. Para o autor espanhol, apesar de não se poder considerar BECCARIA o "pai" da ciência penal - a maior incidência de sua obra estaria na política criminal e na criminologia -, não há dúvidas que o iluminista italiano estabelece as bases que serviriam posteriormente ao delineamento de uma ciência penal voltada à construção de um sistema de garantias ao sujeito e de um marco legitimante à intervenção repressiva do Estado. Nesse sentido, a importância do autor de "Dos delitos e das penas" residiria, notadamente, em firmar os alicerces para o direito penal em um Estado de Direito, por meio da edificação de princípios como os da necessidade e da legalidade das penas, até hoje vigentes.
} 
Todavia, as bases das ideias atualmente atribuídas ao conceito de culpabilidade remontam a momentos históricos pretéritos.

$\mathrm{Na}$ antiga Grécia, a responsabilidade penal era objetiva e a culpabilidade não existia. A despeito de terem sido os grandes pensadores filosóficos da antiguidade e os primeiros a elaborarem uma ciência política, os gregos não foram grandes juristas: não lograram construir uma ciência do direito, nem sequer sistematizar suas instituições de direito privado (GILISSEN, 2007, p. 73).

Esse parco grau de evolução das instituições jurídicas gregas está refletido no direito penal. Conquanto não tenha havido propriamente um direito grego - mas sim vários direitos gregos -, em razão da falta de unidade política e jurídica na Grécia antiga, onde cada cidade tinha seu próprio direito, tanto público, quanto privado, com caracteres específicos e evolução própria, de um modo geral nota-se com relação aos ilícitos penais o desprezo à personalidade (MACHADO, 2010, p. 35). Assim, o crime se perfazia somente com a transgressão à norma objetivamente considerada, desprezando a finalidade ou a intenção do agente.

Apenas com a edificação da civilização romana antiga é que os conceitos de dolo e culpa começam a ser formulados, ainda que primitivamente, para o fim de interpretação das leis. Inicialmente, nos primórdios do sistema jurídico-penal romano, predominava a responsabilidade objetiva, vez que a mera transgressão a preceitos morais então vigentes convertidos em normas políticas - era suficiente para a caracterização do delito (MOMMSEN, 1905, p. 94).

A orientação subjetiva, que passa a diferenciar, no conceito de responsabilidade, o dano produzido intencionalmente daquele ocasionado por falta de cuidado, surge somente na época republicana. Nesse contexto é formulada a ideia de vontade antijurídica, necessária para a punição, de maneira que o erro sobre a contrariedade de determinado fato à lei passa a afastar a imputação, deixando tal evento de caracterizar um delito e de ensejar a imposição de pena (MOMMSEN, 1905, p. 94). Os ainda rudimentares conceitos de dolo e culpa $^{4}$, nessa quadra histórica, não estavam descritos na legislação, de modo que sua

\footnotetext{
${ }^{4}$ Teodoro Mommsen (1905,pp. 95 a 97) explica que o fundamento ético da vontade antijurídica - sem a qual não se caracterizava o delito, nem se legitimava a imposição de pena - poderia aparecer ora sob a forma de ofensa intencional à lei moral e à lei do Estado (dolus), ora sob a forma de falta de cuidado ou negligência culpável (culpa) na observância daquelas normas. A ofensa intencional à lei moral e à lei do Estado se individualizava a partir de cada fato concreto, analisando-se o propósito (animus) de cada ação (de matar, de roubar, etc.) conforme a identificação de determinados elementos constitutivos de cada classe de fatos. Essa vontade delituosa - aplicada a todo o campo do direito -, se designava, em linguagem jurídica, "astúcia", dolus, reforçada a maior parte das vezes pelo adjetivo "má" - "astúcia má", dolus malus -, nos casos em que
} 
análise derivava da interpretação normativa a partir de um caso concreto (MOMMSEN, 1905, p. 98).

Ademais, é também fruto do direito penal romano - de caráter fundamentalmente ético - a presunção jurídica de conhecimento da lei, que surge amparada na ideia de que o homem que vive em sociedade está obrigado a conhecer seus deveres perante o Estado, razão pela qual, afrontando o ordenamento jurídico, pressupõe-se consciente de tal situação (MOMMSEN, 1905, pp. 100 e 101).

Apesar de considerada desde o direito penal romano como pressuposto da punição, ainda que de maneira primitiva, enquanto premissa necessária do dolus malus - isto é, a intenção dirigida a um ato criminoso (CAMARGO, 1993, p. 117) -, a vontade somente ganha relevo na formulação teórica da imputação penal com a edificação do direito canônico. Isso ocorre, notadamente, em razão de uma guinada no foco da atribuição de responsabilidade penal, na qual a avaliação das intenções do agente - desde uma perspectiva moral - passa a preponderar, em detrimento do resultado por ele produzido. Tal mudança fica clara ao observar-se que, em concepções anteriores, a obrigação de reparação do dano era forma usual de sancionar a prática delitiva, enquanto que no direito canônico o desagravo do mandamento divino se dá pela expiação por meio da pena, com o intuito de sanear e purificar a alma (MACHADO, 2010, pp. 36 e 37).

A ideia de que o pecado é a falta querida e imputável ao agente dá origem, no direito, a um problema já comum a outros sistemas - expressamente, a filosofia, as ciências naturais, e a própria religião -, e que desde então acompanha as discussões doutrinárias acerca dos fundamentos da responsabilização penal, a saber: a liberdade de vontade (existe? de que forma atua? quais são seus limites?). Conquanto aparentemente contrário a dogmas cristãos como a predestinação, o debate sobre a existência do livre-arbítrio passou a ser motivo de intensa reflexão, inclusive por parte de pensadores católicos, como Santo AgOSTINHO $^{5}$ e São TOMÁs DE AQUino ${ }^{6}$. Desde então, a polêmica em torno do livre-arbítrio

havia a consciência da injustiça. À violação da lei moral praticada sem a vontade de ação nesse sentido, por sua vez, se dava o nome de culpa, a qual encerra em seu conceito os atos que podem resultar - ou que efetivamente resultam - nocivos para uma terceira pessoa, cujo prejuízo ocasionado, fruto de descuido e de imprudência, constituem uma falta ética - que, conquanto pequena, dá ensejo à punibilidade.

${ }^{5}$ Para o bispo de Hipona, o homem é uma criatura privilegiada na ordem das coisas: feito à semelhança de Deus, desdobra-se em correspondência com os três entes que compõem a Santíssima da Trindade, representados nas três faculdades da alma humana. Assim, a memória, enquanto persistência de percepções produzidas pelos sentidos, corresponderia à essência (Deus Pai), aquilo que é e nunca deixa de ser; a inteligência, por sua vez, seria o correlato do verbo, razão ou verdade (Filho); e, finalmente, a vontade constituiria a expressão humana do amor (Espírito Santo), responsável pela criação do mundo (AGOSTINHO, 1980, pp. 25 e 26). Segundo Agostinho, de todas essas faculdades, a mais importante é a vontade, que intervém em todos os atos do espírito e constitui o centro da personalidade humana. A vontade seria 
jamais deixou de acompanhar as argumentações a respeito da construção de um modelo de responsabilização criminal.

\subsection{Desenvolvimento epistemológico da culpabilidade}

A teoria do delito, de um modo geral, e a culpabilidade, em particular, experimentaram um notável aprimoramento conceitual desde seus primórdios, em que foram delineadas as primeiras formulações abstratas da responsabilização penal de caráter pessoal, esboços das concepções atualmente em voga. Com o intuito de declarar o fundamento da culpabilidade, diversas teorias foram desenvolvidas, coexistindo hoje uma concepção majoritária da culpabilidade - a normativa, com os aportes finalistas -, com outras concepções bastante distintas. De todas elas, serão apresentadas a seguir apenas aquelas que historicamente tiveram maior destaque na doutrina e que guardam relação mais estreita com a polêmica sobre a liberdade de decisão e ação como premissa da culpabilidade.

3.3.1. O positivismo naturalista e a concepção psicológica da culpabilidade

As teorias formuladas ao longo da história do direito penal com o intuito de determinar o fundamento da culpabilidade não surgiram autonomamente, de maneira independente, mas foram desenvolvidas no contexto de cada uma das fases epistemológicas da disciplina. Nesse sentido, tem-se que a concepção psicológica da culpabilidade, a primeira das modernas construções acerca de um conteúdo pessoal da responsabilização criminal, é fruto de um momento epistemológico do direito penal que convencionou-se denominar positivismo naturalista, teoria que pode ser compreendida sob

essencialmente criadora e livre, e nela residiria a possibilidade de o homem afastar-se de Deus distanciando-se do ser e caminhando para o não-ser -, em uma aproximação ao mal. E é no livre-arbítrio da vontade, para o autor, que reside a essência do pecado, compreendido enquanto transgressão da lei divina: na medida em que a alma foi criada por Deus para reger o corpo, o homem, fazendo mau uso do livre-arbítrio, inverte essa relação, subordinando a alma ao corpo e caindo na concupiscência e na ignorância (AGOSTINHO, 1980, pp. 26 e 27).

${ }^{6}$ TOMÁS DE AQuino (2001, p. 753 a 755) entende que o homem é dotado de livre-arbítrio, por considerar que, do contrário, os conselhos, as exortações, os preceitos, as proibições, as recompensas e os castigos seriam vãos. Assim, afirma que o ser humano age com ponderação, porque, por sua potência cognoscitiva, julga se deve atuar em um ou outro sentido. Tal julgamento, segundo o teólogo italiano, não é o efeito de um instinto natural aplicado a uma ação particular, mas de uma certa reflexão comparativa da razão, da qual decorre um julgamento livre pelo homem, que pode seguir diversas direções, inclusive opostas, como visto nos silogismos dialéticos e nos argumentos da retórica. 
dois enfoques: um de caráter normativo e outro de cunho natural e social (MACHADO, 2010, p. 42).

A perspectiva normativa marca um rompimento com o direito natural, na medida em que compreendia o jus puniendi como fruto do desrespeito às normas estatais, constituindo-se, portanto, em mera expressão do direito objetivo. Para seu principal expoente, Karl BINDING (2009, pp. 5 e ss.), a ciência do direito penal deveria ser realizada a partir da norma jurídica, vale dizer, do direito posto. A partir de sua obra "Die Normen und ihre Übertretung" (ou "As normas e sua violação"), publicada em 1872, na qual o conceito de norma é convertido na base da construção do sistema penal, tem início o desenvolvimento da moderna teoria do delito (ALLER, 2009, p. XVI).

Por outro lado, o aspecto natural e sociológico do positivismo, coerente com o momento histórico de intervenção do Estado no desenvolvimento social, é delineado a partir da ideia de que a ingerência estatal na esfera de direitos do indivíduo é legitimada pela defesa social (plano sociológico), e não pelo comando normativo (plano jurídico). Na compreensão de Franz von LISZT (1899, pp. 93 a 96), o interesse juridicamente protegido pelo ente estatal, isto é, o bem jurídico, não é imanente da norma, desprendido do mundo social, mas nasce das relações sociais, fundamentando a pena e o sistema como um todo.

Com influência dessas duas linhas do pensamento positivista, é formulado o naturalismo-normativista, que busca construir no direito penal um modelo de responsabilização que considerasse os elementos naturais do delito por meio da positivação (MACHADO, 2010, p. 42). É a partir deste postulado que surge o sistema Liszt-Beling ${ }^{7}$, responsável pela divisão da ação humana em dois segmentos distintos: o "querer interno" do agente, de um lado, e o "processo causal" perceptível pelos sentidos, ou seja, a conduta corporal do agente e o resultado por ela produzido, de outro, situando-se os elementos

\footnotetext{
${ }^{7}$ Franz von LISZT e Ernst von BELING são os fundadores do primeiro sistema teórico-abstrato do delito, conhecido como sistema causal-naturalista. Os fundamentos do sistema Liszt-Beling radicam na concepção natural de ação - compreendida enquanto elemento geral e comum a qualquer espécie de crime, capaz de ser seu substantivo -, à qual se agregam os atributos legais imperativos da tipicidade, da antijuridicidade e da culpabilidade, e cujo conceito alberga os seguintes componentes: a vontade, a expressão externa dessa vontade por meio de um movimento corpóreo e o resultado. A despeito de alicerçada na noção de ação construída por LISZT, a teoria causal talvez tenha tido por mais importante contribuição a formulação, por BELING, do conceito de tipo penal, em razão da revolução que tal inovação provocou no direito penal ao tornar possível a estruturação do conceito analítico de delito. No modelo proposto por esse autor, o tipo é entendido, basicamente, como a descrição objetiva e neutra do desenrolar de uma conduta, prevista na lei penal, na qual representam papel preponderante o movimento do agente (realidade causal) e o resultado, além de, eventualmente, outras circunstâncias fundamentadoras do crime (TAVARES, 1980, pp. 17 a 22). Decorrência da ideia de tipo, a tipicidade é adequação de uma ação à descrição contida na norma penal. Apesar de não ter qualquer carga valorativa, representa o ponto de referência para as valorações realizadas nas sucessivas etapas da responsabilização penal, razão pela qual foi convertida em característica fundamental do delito (MUÑOZ CONDE, 2001, p. 259).
} 
desse no injusto e os daquele na culpabilidade (TOLEDO, 2008, p. 93). Assim, passou-se a compreender o fato delituoso como formado pela conduta humana, que alberga em seu conteúdo as noções de causa, resultado e relação de causalidade, e o crime, conceituado de maneira tripartida, isto é, constituído pela tipicidade, antijuridicidade e culpabilidade.

De acordo com essa construção doutrinária, a ação é naturalística, vale dizer, consiste na exteriorização dos movimentos do corpo causadora de uma modificação no mundo exterior. Nessa linha, a conduta humana é considerada um processo mecânico regido pelas leis da causalidade, em nítida influência do método científico-natural, coerente com a ideia positivista de tentar transplantar para as ciências humanas e sociais a metodologia das ciências naturais ${ }^{8}$ (TOLEDO, 2008, p. 93).

A tipicidade, por seu turno, consiste na descrição objetiva e formal do aspecto externo da conduta, sem carga valorativa, realizado pelo legislador em um modelo normatizado (MACHADO, 2010, p. 42). Além disso, é um indício da antijuridicidade (LISZT, 1889 , p. 222), a qual, por sua vez, caracteriza-se pela contrariedade do fato ao direito como um todo. A culpabilidade, responsável pelo estabelecimento de uma conexão subjetiva entre o autor e o fato, é psicológica, vale dizer, voltada aos elementos internos, anímicos, do agente.

Esse vínculo subjetivo da culpabilidade psicológica é próprio da orientação metodológica adotada pelo positivismo naturalista, por constituir verdadeira busca empírica de uma relação causal, de natureza psíquica, entre o comportamento humano e o crime - paralela ao vínculo objetivo do nexo de causalidade, de jaez físico, constatado a partir de circunstâncias externas ao agente (RODRÍGUEZ, 2010, p. 262).

A culpabilidade de então, consistindo na mera ligação psicológica entre o agente e o fato por ele produzido, poderia se manifestar de duas formas: o dolo e a culpa. Com relação ao primeiro, caracterizar-se-ia quando o sujeito atuasse com consciência e vontade na produção do resultado criminoso. No que atine à segunda, verificar-se-ia quando

\footnotetext{
${ }^{8}$ Von Lizst foi responsável por orientar o direito penal de acordo com uma política jurídica fundamentada em parâmetros racionais, em que a "ideia de fim" conduziria ao desenvolvimento jurídico. E, assim, partindo de questionamentos próprios da realidade da criminalidade, utilizou-se dos métodos de pesquisa empíricocausais das modernas ciências da natureza, que naquele tempo encontraram lugar na ciência jurídica, para comprovar as deficiências do Direito então vigente, por meio dos resultados de estatísticas criminais. Além disso, estabeleceu a política criminal como parte da política social (positivismo), sendo que sua concepção a respeito foi formulada no conhecido Programa da Universidade de Marburgo, posteriormente publicado com o título "Der Zweekgedanke im Strafrecht" (ou "A ideia de fim em direito penal") (JESCHECK, 2002, pp. 78 e 79).
} 
houvesse previsibilidade, ainda que sem voluntariedade, do resultado delituoso (TOLEDO, 2008, p. 219).

Além disso, a imputabilidade se apresentava como pressuposto da culpabilidade psicológica (CAMARGO, 1993, p. 117). Na formulação de Von LiSZT (1899, pp. 256 e ss.), a imputabilidade estaria caracterizada pela sanidade mental e o amadurecimento intelectual, de maneira que ausentes (ou fortemente debilitadas) essas condições no momento da prática do fato pelo agente, esse seria considerado inimputável e teria, por consequência, sua culpabilidade excluída. Expressamente, duas eram hipóteses de inimputabilidade: "quando falta o desenvolvimento mental" ou "quando falta a saúde mental".

A respeito da primeira, afirma Von LISZT (1899, pp. 262 a 267) que pode ter uma dupla causa. De um lado, a menoridade do agente, circunstância em que o processo de amadurecimento mental estaria ainda em desenvolvimento, o que levaria a um déficit de discernimento e de compreensão dos aspectos relacionados à conjuntura factual em que o sujeito estivesse inserido. Na Alemanha da época, a presunção de prejuízo cognitivo em razão da pouca idade era absoluta até os doze anos e relativa dos doze aos dezoito. De outro, o "desenvolvimento (mental) tolhido", no qual a falta do discernimento necessário para a compreensão do caráter delituoso de determinado fato seria determinado por alguma condição específica do agente - como o surdimutismo.

No que tange à segunda hipótese de exclusão da imputabilidade, a "falta de saúde mental", verificar-se-ia quando o agente, ao tempo do ação, se encontrasse em estado de inconsciência ou de "enferma perturbação da atividade mental" (LiSZT, 1899, pp. 267 a 269). Na explicação do autor, essa hipótese está relacionada não só a enfermidades mentais no sentido próprio, mas também aos "obstáculos ao desenvolvimento do espírito" ("idiotismo" ou "imbecilidade"), aos estados de degeneração mental, às enfermidades psíquicas acompanhadas de "desarranjos mentais" (como o delírio produzido pela febre) e às perturbações transitórias da atividade mental (como o estado de intoxicação). Todavia, conforme esclarece, não basta que essas condições físicas sejam constatadas no agente: para que sejam aptas a afastar a imputabilidade, devem produzir como efeito a exclusão do livre exercício da vontade do sujeito, consoante o artigo 51 do Código Penal alemão de $1871^{9}$, vigente à época.

A despeito de citar a verificação da impossibilidade de autodeterminação do sujeito como necessária ao afastamento da imputabilidade, o autor austríaco sustenta que a

\footnotetext{
9 "Não há acção punível, quando o agente, ao tempo da acção, achava-se em estado de inconsciência ou de enferma perturbação da actividade mental, que exclua o livre exercido de sua vontade." (LISZT, 1899, p. 267).
} 
expressão "livre exercício de sua vontade" não deve ser interpretada literalmente, mas à luz do causal-naturalismo, compreendida como "normal exercício da vontade". Em consonância com a concepção positivista naturalista que orientou seu trabalho, o doutrinador entende que a imputabilidade não guardaria qualquer relação com o livrearbítrio, estando fundada na motivabilidade normal da vontade do agente, isto é, em sua regular aptidão para determinar-se por meio de representações (LISZT, 1899, pp. 256 a 258).

Em verdade, o conceito de culpabilidade proposto pelo professor de Berlim almejava abstrair o problema da liberdade de vontade do processo de responsabilização penal, em razão da árdua polêmica travada na filosofia e nas ciências da natureza acerca da questão, em grande medida catalisada pelas teses deterministas influenciadas pelo positivismo e pela teoria evolucionista de Charles DARWIN ${ }^{10}$ (CEREZO MIR, 2007, p. 860), segundo a qual, sucintamente, em uma luta universal por sua existência e preservação, as espécies da natureza se aperfeiçoam pela sobrevivência de seus mais aptos representantes, que logram produzir descendentes mais adaptados ao ambiente em que estão inseridos, em um processo de seleção ao qual ser humano está sujeito - pouco podendo fazer a respeito e do qual não há fuga possível ${ }^{11}$ (RoDRíGUEZ, 2014, pp. 143 a 147).

Nesse sentido, Von LiszT (1899, pp. 122 a 124) assinala que a culpabilidade é completamente independente da verdade da hipótese do livre-arbítrio, pois essa não seria incompatível com o fato - incontrovertível e incontroverso, em seu ponto de vista - de que

\footnotetext{
${ }^{10}$ Fator determinante da aparição do positivismo naturalista no direito penal foi o apogeu das ciências da natureza, em geral, e do evolucionismo de DARWIN (1859), em particular. Naquele momento histórico, acreditava-se que o único conceito válido de ciência era o positivista, segundo o qual, com exceção da lógica e da matemática, apenas o método experimental próprio das ciências da natureza caracteriza uma atividade como científica. A ressonância que alcançou a conferência ministrada por Julius von KIRCHMANN, em 1847, em oposição ao caráter científico do direito, refletiu o ambiente cientificista que já se instalava, e que triunfaria na segunda metade do século XIX. Nesse contexto, pareceu lógico a Von LISZT que a única salvação do caráter científico do direito seria a incorporação dos métodos científico-naturais. E com essa feição foi elaborado o programa metodológico do positivismo naturalista (MIR PUIG, 2003, p. 197).

11 Na leitura de Víctor Gabriel RoDRíGUEZ (2014, pp. 143 a 147), a despeito de a teoria de DARWIN fundamentar-se na existência de uma constante evolução das espécies - vale dizer, uma regra da natureza à qual é impossível estar alheio -, sendo, por isso, expoente da orientação determinista de matriz biológica, o pesquisador inglês, em verdade, seria partidário da concepção compatibilista de universo (cf., acerca de determinismo e compatibilismo, com maior profundidade, o capítulo "4.4. $\quad$ A contribuição da neurociência ao problema do livre-arbítrio: uma mudança de paradigma?"). Nesse sentido, argumenta o penalista que a posição compatibilista de DARWIN é bastante evidenciada nas oportunidades em que responde às críticas dirigidas à sua formulação teórica, e que, ademais, o biólogo jamais afastou, em sua obra, a existência de princípios metafísicos. Expressamente, ao assinalar que existe nenhuma razão válida para que suas opiniões venham a ferir sentimentos religiosos, bem como que a força do Criador seria até mais bonita se deixasse uma lei a seguir no universo, em lugar de expressar-se por meio de milagres reiterados, DARWIN confirmaria - ainda que de modo sutil, sem maior desenvolvimento científico - uma hipótese filosófica minoritária: que Deus existe sem necessariamente intervir a todo o tempo no mundo, zelando apenas por uma regra de constante aprimoramento.
} 
toda conduta humana é determinável ou determinada por ideias e representações em geral, como, por exemplo, as oriundas da religião, da moral, do direito e do senso prático. Em outras palavras, para o autor, a culpabilidade (psicológica), conquanto compatível com a hipótese do livre-arbítrio, não depende de sua validade, na medida em que a capacidade de determinação de vontade - que seria própria a todo homem maduro e mentalmente são - só é possível de ser concebida ao lado dos vários fatores que regulam a conduta humana e que atuam na prática delituosa por meio de representações do agente.

Assim, estando todas as pessoas (maduras e sãs) submetidas a mencionadas influências - as quais, ademais, não lhes comprometeriam a compreensão das circunstâncias de um fato criminoso -, aquelas, ainda que regulem o comportamento do agente, não são aptas a excluir sua culpabilidade, pois para a concepção psicológica não interessa se o sujeito determina-se livremente, mas se determina-se normalmente. Somente nas hipóteses em que essa determinação não é normal a culpabilidade pode ser afastada, com a aferição e reconhecimento da inimputabilidade do autor do injusto penal.

À concepção psicológica da culpabilidade foi dirigida uma série de críticas, relacionadas à insuficiência da teoria para apresentar respostas adequadas a algumas questões dogmáticas, como a culpa inconsciente e o estado de necessidade exculpante.

Com relação à culpa inconsciente (ou culpa sem representação), o problema é que há impossibilidade de responsabilização penal em razão da falta de representação da possibilidade do resultado pelo agente. Isso porque na culpabilidade psicológica o vínculo subjetivo entre autor e fato é materializado, no dolo, pela intenção da produção do resultado criminoso e, na culpa, pelo conhecimento do perigo suposto, no qual não se quer a lesão, mas se prevê a possibilidade de sua ocorrência. Essa explicação da teoria psicológica da culpabilidade acerca do nexo subjetivo entre o autor e o fato nos casos de conduta culposa do indivíduo só permite a responsabilização penal por culpa nas situações em que essa for consciente, vez que se for inconsciente tal ligação psicológica não estará caracterizada $^{12}$ (MACHADO, 2010, p. 50).

\footnotetext{
${ }^{12}$ Valendo-se de um exemplo atual, fica nítida a inexistência de vínculo psicológico entre o agente e seu fato: alguém que dirige um veículo com excesso de velocidade, em uma rua deserta, e repentinamente atropela um pedestre que surge inesperadamente. Não há nexo psicológico entre autor e fato, uma vez que não houve previsão do resultado (TOLEDO, 2008, p. 223).
} 
Quanto ao estado de necessidade exculpante, a incongruência reside em que a relação psicológica entre o autor e o fato está caracterizada, na modalidade dolosa, mas a culpabilidade é excluída (CAMARGO, 1993, p. 119).

Outra crítica é apontada por Juarez TAVARES (1998, p. 145): na tentativa de conceituar o delito a partir de um significado atemporal, sociologicamente neutro e psicologicamente estéril, a concepção psicológica da culpabilidade teria fundamentado a responsabilidade não em características do agente, mas nos elementos que constituem o fato. Assim, o delito seria visto, segundo o autor, como uma conduta objetiva, cujos elementos se configuram na realidade fenomênica e são retratados de fora, enquanto que a pessoa é utilizada como mero objeto da imputação, na medida em que o dolo e a culpa elementos constitutivos da culpabilidade - funcionariam apenas como condições (a serem preenchidas ou não) para tornar o agente responsável pelo injusto praticado.

Em razão de suas inconsistências teóricas, a concepção psicológica da culpabilidade perdeu espaço na doutrina penal, sendo superada, no decorrer dos anos, por novas formulações.

3.3.2. O positivismo normativista e a concepção psicológico-normativa da culpabilidade

O final do século XIX e o início do século XX marcam o declínio da influência das ciências naturalísticas no campo do direito penal. Nesse contexto, uma grande redefinição metodológica - voltada à filosofia neokantiana em defesa da ciência dos valores - foi principiada, abrindo espaço para o surgimento do positivismo normativista e a formulação da concepção normativa da culpabilidade (MACHADO, 2010, p. 51).

Nesse ambiente, a filosofia neokantiana surge como superação do positivismo naturalista e do postulado segundo o qual a atividade jurídica, para ser considerada ciência, deveria ser concebida segundo o modelo das ciências naturais, que se utilizam de métodos como a observação e a experimentação para analisar, de um modo causal-empírico, a realidade. Tal movimento se inicia com o reconhecimento de que, para compreender a realidade em sua totalidade, o conhecimento derivado das ciências naturais é insuficiente, de maneira que, com vistas a alcançar aquele objetivo, revela-se necessário recorrer a outras fontes, representadas pelas ciências culturais ou espirituais (MUÑOZ CONDE, 2001, pp. 176 e 177). 
$\mathrm{Na}$ busca de fundamentar um conceito de ciência do espírito, em contraposição ao conceito positivista de ciência, o neokantismo não propõe uma mudança de objeto, mas uma guinada de método. Segundo essa corrente filosófica, as ciências do espírito, relacionadas à conduta humana, não poderiam ter o mesmo método das ciências positivas ou experimentais. Em termos concretos, significa dizer que se as ciências experimentais supõem a aplicação das categorias do entendimento à matéria empírica, as ciências do espírito requerem a subsunção dessa matéria empírica a outro tipo de categorias, estabelecidas a priori, específicas deste campo do conhecimento. As ciências naturais e as espirituais, portanto, não se distinguem por seu objeto - que é igual, isto é, a mesma matéria fenomênica -, mas pelas categorias a priori mediante as quais se pode tomar conhecimento daquele (MIR PUIG, 2003, pp. 210 a 214).

Três autores podem ser identificados como expoentes do neokantismo. Heinrich John RICKERT, filósofo alemão, tem por principal contribuição a introdução do conceito de valor às ciências "histórico-culturais". Para esse autor, não cabe ao historiador emitir juízos de valor subjetivos, mas é sua tarefa referir valores relacionados aos fatos que estuda, isto é, selecionar aqueles fatos ou aspectos que merecem atenção desde determinadas perspectivas valorativas (MIR PUIG, 2003, p. 216).

Emil LASK, por sua vez, tem o mérito de haver lançado as bases do específico método cultural correspondente à dogmática jurídica, incluindo a ciência do direito no rol das ciências culturais. Se RICKERT assinalou que o objeto de toda ciência cultural se refere a valores, LASK identifica o caráter teleológico dos valores referentes ao direito, ao afirmar que a formação jurídica de um conceito é feita sempre "colorida teleologicamente" (MIR PUIG, 2003, p. 218). Em outros termos, para o autor alemão, tudo o que incide no campo do direito perde seu caráter naturalístico livre de referências valorativas (MUÑOZ CONDE, 2001, p. 177).

Todavia, LASK apenas se ocupou de descobrir a referência a valores e a fins na ciência jurídica, sem especificar seu conteúdo. Isso ficou a cargo de outro pensador alemão, Gustav RADBRUCH, que parte da ideia kantiana da impossibilidade de derivar os valores da realidade e de impor o dever ser sobre o que é, para assentar que o plano dos valores e o mundo dos fatos coexistem como órbitas paralelas, que não se entrecruzam. Para RADBRUCH, essa relação entre o valor e a realidade, entre o "dever ser" e o "ser" denominada dualismo metodológico - é o que caracteriza a distinção entre ciências naturais e ciências jurídicas. Ainda segundo o autor, a separação entre ambas as esferas - valor e 
realidade - é decisiva para conceber as ciências culturais, sobretudo a jurídica, como autênticas ciências, distintas e independes das ciências naturais. $\mathrm{Na}$ compreensão do professor de Heidelberg, toda atitude racional e sistemática para explicar ou compreender a realidade é ciência, residindo a diferença entre as distintas ciências unicamente no método empregado: ontológico, nas naturais; e axiológico, nas culturais (MUÑOZ CONDE, 2001, pp. 178 e 179).

A despeito das inovações mencionadas, o positivismo jurídico não é abandonado pelo neokantismo jurídico-penal, para quem o conceito de realidade apreensível pela ciência do direito é idêntico ao positivista. Em verdade, de forma nenhuma o neokantismo representou uma superação do positivismo, mas uma complementação a essa teoria, pois o que havia nela de objetivo não foi modificado, acrescentando-se apenas o aspecto subjetivo no processo de interpretação (MIR PUIG, 2003, p. 219).

Nesse sentido, na teoria neokantiana permaneceram alguns elementos da formulação do positivismo naturalista, como o conceito causal de ação, a separação das partes objetiva e subjetiva do fato em antijuridicidade e culpabilidade, respectivamente, além da permanência do dolo e da culpa na culpabilidade. Os aportes da metodologia referida a valores do neokantismo, por outro lado, não promoveram um rompimento completo com o positivismo: a concepção de ação como referida a valor - enquanto "comportamento humano" -, por meio da qual se permitiu compreender o sentido da omissão e de algumas ações, como a de injuriar, nas quais fatores normativos são mais importantes do que a causalidade ${ }^{13}$; a noção de tipo como meio formal de expressão do juízo de desvalor da antijuridicidade, isto é, a formulação de um "tipo de injusto", em substituição à concepção do tipo como neutro de valor; e a compreensão da antijuridicidade e da culpabilidade - que passaram a ser considerados dois juízos de valor fundamentais à teoria do delito - como danosidade social e como reprovabilidade pela motivação contrária a norma, respectivamente (MIR PUIG, 2003, p. 221).

Apesar da guinada do método naturalístico para o método valorativo, subsistiu no pensamento neokantiano, junto a nova perspectiva das ciências culturais, a visão científiconatural própria do positivismo jurídico, o que originou algumas contradições na teoria. Um exemplo disso está relacionado ao conceito causal de ação: com o neokantismo, deixa de

\footnotetext{
${ }^{13}$ Com relação à omissão, não se explicava satisfatoriamente desde uma perspectiva meramente naturalística, vale dizer, enquanto "contenção dos nervos motores", uma vez que faltava referência à "ação esperada". Quanto à injúria, não consiste nas manifestações percebidas pelos sentidos, mas no significado valorativo da ofensa (MIR PUIG, 2003, pp. 221).
} 
ser compreendido como uma imposição da realidade naturalística em si mesma, passando a ser encarado a partir de um processo interpretativo amparado em categorias do conhecimento humano. Ocorre que, de acordo com tais categorias, a ação segue entendida em seu aspecto científico-natural. Ao seguir ancorado em um conceito causal de ação, o neokantismo vulneraria seu próprio ponto de partida metodológico: a independência das categorias das ciências naturais e das espirituais (MIR PUIG, 2003, pp. 222 e 223).

Essa e outras incongruências teóricas foram apontadas por alguns autores, como Hans WELZEL, abrindo espaço para que a teoria neokantiana fosse superada posteriormente por novas formulações. De todo modo, essa corrente metodológica tem o mérito, além de trazer o juízo de valoração à estrutura do delito e de estabelecer o conteúdo material do tipo e da antijuridicidade, de verificar que os elementos do crime não são constatados empiricamente, mas atribuídos pelo ser humano, passando a ter validade enquanto fenômeno jurídico, e não meramente como um fenômeno natural. Sobre essas bases a concepção normativa da culpabilidade foi formulada.

A concepção normativa da culpabilidade surge como resultado da redefinição metodológica proposta pela corrente teórica do neokantismo, alcançando relevante difusão entre os pesquisadores da época, o que levou ao delineamento de várias acepções distintas acerca da teoria. Apesar de diferentes nos detalhes, seu núcleo é comum: a profunda alteração do centro da responsabilidade penal, que passou da vinculação entre o agente e o fato (culpabilidade psicológica) para o poder agir de outro modo, com base na potencialidade do conhecimento do injusto (MACHADO, 2010, p. 54).

Com a teoria normativa da culpabilidade, é introduzido no conceito de culpa (em sentido amplo) um elemento normativo, vale dizer, um juízo de valor: a reprovabilidade do ato praticado. Assim, para que o fato seja culpável não é mais suficiente que seja doloso ou culposo, sendo necessário também que seja censurável ao autor. Nesse sentido, o dolo e a culpa (em sentido estrito) deixam de ser espécies da culpabilidade, passando a constituir alguns de seus elementos, juntamente a outros: o juízo de censura que se faz ao autor do fato e, como seu pressuposto, a exigibilidade de conduta conforme à norma (TOLEDO, 2008, p. 223).

Coerente com as contribuições do positivismo normativista, a concepção normativa da culpabilidade deixa de identificar a responsabilidade respaldando-se exclusivamente em elementos do próprio fato, passando a fundamentá-la no juízo jurídico que se faz sobre o 
agente. Essa avaliação, conquanto normativa, é feita com base em pressupostos fáticos decorrentes de outro juízo de cognição preestabelecido. Com efeito, a imputabilidade é assentada em um juízo sobre a capacidade abstrata de entender e de autodeterminar-se; o conhecimento do injusto é inferido a partir de um juízo de possibilidade; e o poder agir de outro modo - que fundamenta a reprovação - é consequência de um juízo normativo hipotético (TAVARES, 1998, pp. 145 e 148). Na análise de Juarez TAVARES (1998, p. 148), a base dessa culpabilidade é um puro juízo jurídico de sustentação normativa, alheio à realidade antropológica e sensorial humana.

A mais notável contribuição do neokantismo no que diz respeito à estrutura da culpabilidade foi nela introduzir o conteúdo material, por meio de critérios valorativos, tomando o ser humano enquanto indivíduo racional, livre e responsável. Com essa nova formulação se tornou possível questionar a intervenção penal, ao se buscar respostas à indagação de por que o Estado tem o poder de impor uma pena a determinadas pessoas, qualificadas como culpáveis (MACHADO, 2010, p. 56).

Dos vários autores adeptos da concepção normativa da culpabilidade, quatro merecem ser destacados, pela importância de seu trabalho na construção dos principais postulados da teoria: Reinhard FRANK, James GoLDSCHMIDT, Berthold FreUdENTHAL e Edmund MEZGER.

Reihard FRANK (2002, pp. 25 a 27) foi o precursor da culpabilidade normativa, em estudo publicado em 1907 ("Über den Aufbau des Schuldsbegriffs"; ou "Sobre a estrutura do conceito de culpabilidade"), no qual criticou os autores de seu tempo por considerarem as relações psíquicas - vale dizer, o dolo e a culpa -, que ligam subjetivamente o autor ao fato, a essência da culpabilidade. Para FRANK, tal concepção era limitada, pois lhe parecia claro que havia circunstâncias concomitantes ao ato, externas à psique do agente, que deveriam ser levadas em consideração na formulação do conceito de culpabilidade ${ }^{14}$.

\footnotetext{
${ }^{14}$ Para ilustrar seu argumento, isto é, de que a culpabilidade depende de fatores externos à mente do agente, o doutrinador se vale de duas situações hipotéticas: a de um operador de caixa de comércio que necessita urgentemente de dinheiro para cuidar da esposa doente e dos vários filhos que tem para criar; e a de um transportador de valores, que vive confortavelmente, com boa condição de vida. Cada qual por sua razão, ambos apropriam-se, valendo-se de seus empregos, de dinheiro alheio (FRANK, 2002, p. 28). Como bem nota Víctor Gabriel RODRÍGUEZ (2010, p. 264), revela-se evidente a diferença de culpabilidade entre um e outro ato. Todavia, o ponto que FRANK pretende destacar é outro: a desnecessidade de adentrar à relação psíquica do agente para alcançar a culpabilidade. Em outras palavras: não é preciso se perguntar o que pensava ou representava o agente no momento da ação, pois o grau de reprovabilidade da conduta é constatável a partir da observação da realidade, mesmo que desde a perspectiva de circunstâncias subjetivas. No exemplo apresentado, o operador de caixa que se apropriou de dinheiro alheio para amparar a esposa doente cometeu
} 
Assim, desde logo o autor encarou - e propôs-se a demonstrar - a culpabilidade como elemento complexo, isto é, composto não apenas por dolo e culpa, mas também por algo que lhe era até mais intrínseco: sua relação com a conjuntura do fato (FRANK, 2002, pp. 30 a 32). Disso decorre que a relação culpabilidade-dolo e culpabilidade-culpa deixa de ser compreendida como uma relação contingente-conteúdo. Na formulação de FRANK, o dolo e a culpa (ou o vínculo psicológico) perdem a condição de essência da culpabilidade, abrindo caminho para que outra característica assumisse tal condição: na concepção normativa, culpabilidade é reprovabilidade (RODRÍGUEZ, 2010, p. 264).

Partindo dessas premissas, o professor de Tübingen delineou seu pensamento acerca da culpabilidade, sustentando esse elemento em um tripé com os seguintes componentes: a aptidão normal do autor (imputabilidade) - que para FRANK não fazia sentido na condição de mero pressuposto da culpabilidade (isto é, enquanto capacidade de culpabilidade, na terminologia de então); a relação psíquica do autor com o fato, seja ela concreta (dolo), seja ela uma possibilidade abstrata (culpa); e a normalidade das circunstâncias nas quais foi praticada a conduta típica (FRANK, 2002, pp. 40 e 41).

Os fatores externos à psique, incorporados por FRANK à culpabilidade, e representados pela imputabilidade e, principalmente, pela normalidade das circunstâncias, permitiram que o juízo de culpabilidade passasse a ser feito normativamente.

Tomando por base a estrutura elaborada por FRANK, James GOLDSCHMIDT, em artigo em homenagem àquele autor, publicado em 1930 ("Normativer Schuldsbegriff"; ou "Concepção normativa da culpabilidade") ${ }^{15}$, acentua o caráter normativo da culpabilidade, ao considerar que essa supõe o descumprimento de uma norma de dever, que rege a conduta interna independentemente da norma jurídica, que regula a conduta externa e cuja infração determina a antijuridicidade (CEREZO MIR, 2007, p. 861) ${ }^{16}$.

Na formulação proposta por GOLDSCHMIDT, estabelece-se um normativismo puro, a partir da outorga de um conteúdo jurídico ao elemento normativo contrariedade ao dever. Essa norma de dever consiste em um mandado que compele o indivíduo a motivar-se pelas

um ato menos reprovável que o do transportador de valores, e para que se atinja essa conclusão não é necessário investigar a relação psicológica do agente com o ato.

${ }^{15}$ No livro "Der Notstand: ein Schuldproblem", editado em 1913, GOLDSCHMIDT esboçara as primeiras linhas do pensamento que viria a apresentar de maneira mais elaborada anos depois.

${ }^{16}$ Essa concepção parte da independência das normas: a de Direito (ou jurídica), definidora da noção de injusto, e a de dever, própria da culpabilidade. Na construção de GOLDSCHMIDT, a norma de dever diferenciase da norma jurídica na medida em que enquanto aquela se refere à conduta externa, isto é, à causalidade violada pelo ato, essa diz respeito à conduta interna, vale dizer, à motivação que, ao ser lesionada, faz surgir a culpabilidade do autor - trata-se de uma norma que determina que o particular se motive pelas representações de valor jurídico (MACHADO, 2010, p. 60). 
representações de valor jurídico dirigidas à determinação de sua vontade, independentemente de fatores morais e éticos a respeito (MACHADO, 2010, p. 60).

O professor de Berlim parte do pressuposto de que a assertiva segundo a qual "se um homem cumpre suas obrigações, não há de se perguntar quais são os motivos para tanto" não pode ser tomada como verdade absoluta. Na compreensão do doutrinador, a asserção é verdadeira em termos: há uma norma de dever, orientada ao cumprimento do dever como um todo, a qual impõe que exista uma motivação conforme o Direito. Contudo, só é exigível obediência a essa norma em situação de motivação normal. Se as normas de dever têm limitações, essas podem ser interpretadas como limitações à motivação, o que caracteriza, pois, a exigibilidade (GOLDSCHMIDT, 2002, pp. 91 e 92).

GOLDSCHMIDT (2002, pp. 104 e 105) dá à culpabilidade o contorno de um juízo de reprovação composto pela exigibilidade, definida como a obrigação de se motivar pela representação do dever indicado na norma jurídica - o que pressupõe do autor o poder ou domínio do fato. Destarte, para o autor alemão, o conteúdo material da culpabilidade está refletido na ideia do dever de observância à norma, de maneira que o crime doloso consiste na infração desse dever, enquanto que o crime culposo se fundamenta na infração de um dever de cuidado, caracterizando, também, a transgressão a um dever jurídico (GOLDSCHMIDT, 2002, pp. 98 e 99).

Além disso, GoldsCHMidT (2002, pp. 124 e ss.) sustenta a possibilidade de graduação da culpabilidade: será maior na medida do afastamento do autor da motivação justa e menor quanto mais se aproximem as circunstâncias do fato das causas de exclusão.

Seguindo a trilha normativa de FRANK e de GOLDSCHMIDT, Berthold FrEUDENTHAL lança em 1922 a obra "Schuld und Vorwurf" (ou "Culpabilidade e reprovação"), alinhandose à ideia de que a exigibilidade é o requisito geral da culpabilidade, isto é, o núcleo do juízo de reprovação, de maneira que não se pode exigir do sujeito comportamento conforme o Direito se circunstâncias relacionadas ao fato o impediram de atuar nesse sentido (FREUDENTHAL, 2003, p. 69).

A avaliação acerca da exigibilidade, na concepção do professor de Frankfurt, deve considerar as possibilidades de atuação alternativa (à conduta típica) do indivíduo, de quem se espera agir conforme resoluções provenientes do saber popular. Tal reflexão deve partir, portanto, de um raciocínio hipotético e de uma apreciação valorativa que levem em conta não uma pessoa abstratamente considerada, mas o próprio sujeito em questão, uma vez que o dever de evitar pressupõe o dever de fazê-lo, o que só pode ser examinado, para 
FREUDENTHAL, desde uma projeção individualizadora, que não ignore a conjuntura em que o autor atuou (FREUDENTHAL, 2003, p. 72).

$\mathrm{Na}$ concepção de FREUDENTHAL, a exigibilidade aparece como um elemento normativo autônomo da culpabilidade, construído sobre a premissa do livre-arbítrio, isto é, a capacidade de autodeterminação conforme o sentido. Para o autor alemão - que relaciona exigibilidade e poder atuar de outro modo - a culpabilidade seria o juízo de censura do sujeito que agiu (injustamente), enquanto podia e devia atuar de outra forma (MACHADO, 2010, p. 63).

Dentre as contribuições da teoria formulada por FREUDENTHAL, destaca-se o deslocamento da inexigibilidade penal do âmbito da justificação para a exculpação e a tese de que as causas de exclusão da culpabilidade não podem ficar limitadas àquelas estabelecidas por lei, devendo haver uma abertura no sistema (supralegalidade) para que situações concretas não previstas no diploma normativo possam ser passíveis de exculpação pela inexigibilidade. A inexigibilidade, assim, é situada como causa geral de exclusão da culpabilidade, apta a exculpar o sujeito que pratica um injusto penal, mas de quem, consideradas as circunstâncias do fato, não se possa exigir comportamento diverso daquele realizado (FREUDENTHAL, 2003, pp. 98 a 100).

A concepção normativa da culpabilidade, iniciada por FRANK, alcançou em Edmund MEZGER - responsável por firmar a teoria na condição de tratadista - seus contornos definitivos. Aproveitando as contribuições de outros autores normativistas, o professor de Munique estrutura a culpabilidade com três elementos básicos: um relacionado ao estado da personalidade do agente (imputabilidade); outro relativo à vinculação psicológica com o fato (dolo ou culpa); e um terceiro afeto à configuração de circunstâncias internas e externas da ação (que o autor aglutina genericamente em um conjunto identificado por "causas de exclusão da culpabilidade") ${ }^{17}$ (MEZGER, 1957, pp. 46 a 53).

Coerente com esse modelo, MEZGER (1957, pp. 9 e 10), reafirmando o caráter jurídico-penal da culpabilidade - isto é, construído por meio de valorações normativas -, define esse elemento do delito como o conjunto de pressupostos fáticos da pena que fundamentam, frente ao sujeito, a reprovabilidade pessoal da conduta antijurídica. Do pensamento desse penalista, firma-se que a concepção normativa da culpabilidade não se esvazia de conteúdo na relação psicológica do autor com o fato, mas que é concebida

\footnotetext{
${ }^{17}$ Com relação a essas, o autor ressalta que não constituem meras representações internas de atos externas,
} mas verdadeiras condições exteriores que podem excluir a culpabilidade (RODRÍGUEZ, 2010, p. 265). 
enquanto um juízo valorativo - o da reprovabilidade, que leva em conta uma série de fatores, e não somente o dolo e a culpa -, a ponto de a culpabilidade passar a ser conceituada como o injusto pessoalmente reprovável (MACHADO, 2010, p. 67).

Todas as contribuições teóricas acima apresentadas, ajustadas e lapidadas, foram responsáveis pelo delineamento de uma concepção normativa da culpabilidade, em contraposição ao modelo anteriormente em voga, na tentativa de superar suas limitações teóricas. De todas as mudanças estruturais propostas pelos autores citados, logrou-se construir uma formulação que se consolidou a sua época, cujos postulados podem ser sintetizados da seguinte maneira: a culpabilidade, concebida normativamente, é essencialmente um juízo de reprovação ao autor do fato, sendo composta pela imputabilidade, pelo dolo ou culpa stricto sensu (negligência, imprudência ou imperícia) e pela exigibilidade, nas circunstâncias, de um comportamento conforme ao direito (TOLEDO, 2008, p. 223).

Significa dizer que a censura da culpabilidade só pode ser feita, portanto, ao autor de um injusto penal se ele, ao praticar a ação punível, não agiu de outro modo, conformando-se às exigências do direito, quando, nas circunstâncias, podia tê-lo feito, vale dizer: tinha grau suficiente de autodeterminação e de compreensão (imputabilidade) que o tornava apto a reprimir, frear ou desviar sua vontade voltada - ou o impulso que o impelia para o fim ilícito (possibilidade de outra conduta) e que, ainda assim, consciente e voluntariamente (dolo) ou com negligência, imprudência ou imperícia (culpa stricto sensu), desencadeou o fato punível (Toledo, 2008, p. 223). Com a estruturação desse modelo e a superação da concepção anterior, deixou de ser necessário recorrer a um vínculo psicológico do agente com o fato para caracterizar a culpabilidade: essa, enquanto juízo de reprovabilidade da ação ou omissão, só pode ser perfeita a partir da análise das circunstâncias, pelo aplicador da norma (RoDRíGUEZ, 2010, p. 266).

Além disso, a partir das renovações dogmáticas apresentadas, uma característica fulcral da culpabilidade foi alterada: diferentemente da teoria psicológica, baseada na motivabilidade normal do sujeito, a concepção normativa é ancorada no livre-abítrio do agente. Aqui, nitidamente representado enquanto pressuposto da exigibilidade de conduta conforme o direito, cuja premissa é a possibilidade de o agente ter atuado de maneira diversa ao ato típico e antijurídico - ainda que, pragmaticamente, seja impossível 
demonstrar que a escolha da conduta não sofreu variações circunstanciais que modificaram (ou regularam) a vontade (CAMARGO, 1993, p. 121).

A despeito do grande avanço dogmático que representou, em vários sentidos, a concepção normativa da culpabilidade constituiu, pelo menos desde uma perspectiva, um regresso: a retomada do curso evolutivo do direito penal interrompida pela concepção psicológica. Esse retorno está identificado notadamente no conceito de dolo, que volta a ser o dolus malus construído pelos romanos e vigente também no medievo, cujo conteúdo era mais elaborado que o da formulação puramente psicológica do dolo ${ }^{18}$. O dolo da concepção normativa da culpabilidade é o dolo mau, muito próximo do dolus malus romano. Isso porque nessa teoria o elemento normativo do dolo é a consciência da ilicitude, que estando presente possibilita o juízo de reprovabilidade. Assim, para caracterizá-lo, o agente deveria agir voluntariamente, com previsão do resultado, perseguindo um fim que sabe ilícito, de sorte que, definido nesses termos, o dolo não mais seria do que o dolus malus romano, retomado (TOLEDO, 2008, pp. 224 e 225).

Esse conceito de dolo, todavia, pareceu apresentar falhas estruturais, ao permitir a exculpação do autor de um injusto penal em certas circunstâncias cuja necessidade de punição afigurara-se patente. Expressamente, o modelo de dolo normativo, constituído pela consciência da ilicitude (além da voluntariedade e da previsão) não oferecia respostas dogmáticas adequadas a situações de criminalidade habitual. Conforme explica Assis TOLEDO (2008, p. 225), o tipo criminológico do delinquente habitual é geralmente formado por sujeitos nascidos em famílias desajustadas, criados e educados em um ambiente social agressivo, muitas vezes onde a criminalidade é tônica e a conduta delituosa aparece como prática comum, normal, adequada. No caso desses indivíduos, cujos padrões de conduta são modelados segundo as regras do crime, que não tiveram a oportunidade de formar uma consciência ética, que não sabem distinguir o certo do errado, o lícito do ilícito, como exigir "consciência atual da ilicitude"? Tendo jamais sabido o que é ilícito, não estará caracterizada nesses sujeitos a consciência da ilicitude. Isso significará, de acordo com a culpabilidade normativa, que um agente nessas condições age sem dolo e, portanto, sem culpabilidade, razão pela qual não se pode responsabilizá-lo penalmente.

\footnotetext{
${ }^{18}$ Segundo Francisco de Assis Toledo (2008, p. 220), o conceito de dolo formulado pelo direito romano apresentava-se mais complexo e enriquecido do que o dolo da teoria psicológica da culpabilidade. Isso porque era distinguido em duas espécies: o dolus bonus e o dolus malus. O primeiro designava a astúcia, a sagacidade para enganar. O segundo, por sua vez, indicava essa mesma astúcia, quando utilizada para a obtenção de um proveito ilícito, e não simplesmente para enganar: tratava-se da intenção má, perversa, orientada a prática de um ato criminoso.
} 
Desse problema, nota-se que assim como a concepção psicológica da culpabilidade não satisfez às exigências do direito penal, tampouco o fez a teoria normativa, que inexoravelmente se revelou insuficiente para abranger e justificar a punição de certos tipos de transgressores da lei penal. Assim, sua superação por uma nova e mais consistente formulação doutrinária era questão de tempo.

\subsubsection{O finalismo e a concepção normativa pura da culpabilidade}

O finalismo, fase das mais importantes da evolução epistemológica do direito penal, apresenta-se com dois intentos: de um lado, reagir ao irracionalismo totalitário da Escola de $\mathrm{Kiel}^{19}$, em um momento pós segunda grande guerra; e, de outro, superar o positivismo, tarefa não realizada pelo neokantismo, que conservou em sua formulação vários conceitos daquela corrente do conhecimento, como, por exemplo, o objeto da ciência jurídica, que para ambas é apenas o direito positivo (PRADO, 2010, p. 104).

Em termos metodológicos, a orientação finalista representa uma superação do subjetivismo gnoseológico e do relativismo valorativo da filosofia neokantiana ${ }^{20}$. Essas

${ }^{19}$ A Escola de Kiel surgiu na década de 1930 fundamentalmente por motivos políticos, como pioneira do nacional-socialismo na doutrina penal e como corrente oposta à postura essencialmente liberal da época de Weimar (JESCHECK, 2002, p. 224). Naquela época, no contexto do terceiro Reich, a vontade do Führer se apresentava como fonte máxima de poder e, consequentemente, de criação jurídica. Assim, o ponto central da teoria jurídica nazista consistia na negação do caráter geral e abstrato da norma, de modo que a solução de casos submetidos ao judiciário era deixada ao arbítrio do julgador da época, o qual havia previamente jurado fidelidade ao líder supremo (JIMÉNEZ SEGADO, 2009, p. 472). De um modo geral, o direito penal nacionalsocialista partia dessas premissas, ostentando como características principais: $(i)$ o abandono da proteção dos bens jurídicos individuais como fim do direito penal, com a mudança dos paradigmas do individualismo e do racionalismo - consequências históricas do pensamento do iluminismo e do liberalismo - para o do primado incondicional da nação e de seus valores tradicionais, frente aos interesses do indivíduo; (ii) o abandono do princípio da legalidade, com a substituição do conceito formal de delito - representado pela infração do direito positivo -, por um conceito material de delito baseado na "contradição à comunidade" ("Gemeinschaftswidrigkeit") da conduta; (iii) a subjetivação dos elementos do injusto, com a culpabilidade fundamentada na não orientação da vontade, pelo sujeito, conforme os valores da comunidade, e a pena, por sua vez, na infração ao dever de fidelidade aos valores comuns; e (iv) a unidade das ordens jurídica e moral, vez que o direito penal se ocupa da proteção da comunidade mediante o isolamento de seus inimigos, isto é, daqueles que afrontam a ordem moral do povo (HOYER, 2009, pp. 42 a 45).

20 A metodologia neokantiana é considerada subjetivista por partir da premissa de que o conhecimento científico está condicionado por categorias a priori da mente do sujeito. Para o neokantismo, o conhecimento científico é uma síntese de "matéria", fornecida pela experiência, e "forma", oferecida pelas categorias mentais. A realidade fenomênica desordenada e amorfa constitui a "matéria" de todo conhecimento científico, tanto para as ciências naturais, quanto para as culturais, de maneira que a diferença entre essas residiria não em seu objeto (que é o mesmo), mas nas diferentes categorias a priori que a ele se aplicam. Nesse sentido, não é o objeto, mas o método, que diferencia as várias classes do conhecimento científico. A consequência disso é que os valores não residem no próprio objeto, mas constituem o resultado da aplicação, a ele, das categorias a priori do sujeito. Os valores, portanto, não provém do objeto, mas do método, razão pela qual são subjetivos, e não objetivos. Nessa linha, o subjetivismo epistemológico neokantiano levou a um relativismo (gnoseológico) valorativo, fortemente defendido por Gustav RADBRUCH antes da Segunda Guerra Mundial (MIR PUIG, 2003, p. 226). 
características são criticadas pelo finalismo porque, segundo essa diretriz, não é verdade que a distinção entre ciência natural e ciência espiritual está no método (integrado por valores subjetivos), e não no objeto. Para a doutrina finalista, é o objeto que determina o método (PRADO, 2010, p. 105).

A passagem do subjetivismo ao objetivismo constitui o fundamento metódico da teoria do delito desenvolvida pelo finalismo. A substituição do relativismo valorativo pela afirmação de "verdades eternas" e construção de estruturas lógico-objetivas ${ }^{21}$ é a pedra angular da filosofia jurídica de Hans WELzEL. Para o autor, a análise do objeto do direito penal vem precedida por exigências metodológicas, e não o contrário. Em concreto, isso significa, por exemplo, que o estudo welzeliano acerca da ação - como objeto do direito penal - foi consequência do ponto de partida metódico, vale dizer, da metodologia ontologista que aplicou à dogmática jurídico-penal (MIR PUIG, 2003, pp. 226 e 227).

A despeito de alicerçado no ontologismo ${ }^{22}$, não se pode caracterizar o finalismo como doutrina pura e unicamente ontológica, uma vez que nela o aspecto axiológico, ainda

${ }^{21}$ Depois da segunda grande guerra, e como consequência da crise do positivismo jurídico, foi submetido a uma revisão o princípio metodológico fundamental da escola subocidental alemã: a distinção entre o ser e o dever-ser como duas esferas independentes. Nesse contexto, houve um renascimento das concepções de direito natural, voltadas a extrair da natureza do homem o dever-ser do direito. Apesar de crítico do postulados neokantianos, tampouco WeLZEL se coaduna com as teorias jusnaturalistas, as quais criticou duramente, por crer que todas elas incorriam no mesmo vício lógico: incluir previamente na natureza humana somente aquelas características que se consideram valiosas e em seguida obter seu caráter valioso de pertencer à "natureza humana". Todavia, em sua análise crítica das diversas concepções jusnaturalistas, vislumbra o doutrinador, na periferia ontológica, a existência de algumas estruturas lógico-objetivas vinculantes para o legislador, o qual não estaria somente vinculado às leis da natureza física, mas deveria também atender a determinadas estruturas lógico-objetivas da matéria tratada, de maneira que, caso contrário, essa regulação seria necessariamente falsa. Para WELZEL, essas estruturas lógico-objetivas não podem ser ignoradas por valoração ou regulação jurídica alguma. A despeito de não formarem um sistema, subjazem-se à matéria regulada pelo direito, como pontos isolados. Entre as várias estruturas lógico-objetivas, estariam: 0 conceito ontológico da ação humana (consistente no exercício de uma atividade finalista); e a culpabilidade (que pressupõe que o autor tivesse podido atuar de acordo com a norma) (CEREZO MIR, 2004, pp. 9 e 10).

${ }_{22} \mathrm{O}$ neokantismo, como já exposto, considera a realidade como produto de um processo de transformação, cujas condições fundamentais estão inscritas na estrutura do pensamento humano. Consoante a forma categorial da síntese que é em cada caso aplicada, o mesmo "dado material" de que parte o processo de transformação surge-lhe enquanto resultado ora como "natureza", ora como "cultura" - isto é, como fenômeno social condicionado por leis causais, ou como fato dotado de significação jurídica. A muitos juristas esta doutrina afigurou-se acertada, porque o "fato" juridicamente relevante, se posto em confronto com o acontecimento total de que o extraímos, não é na realidade senão o resultado de uma transformação intelectual, a saber: a sua apreciação à luz de critérios jurídicos. Mas será verdade que os diversos modos em que se nos apresentam as coisas da natureza inanimada, a vida orgânica, as sensações e vivências anímicas, as obras do espírito ou o comportamento significativo de uma pessoa, assentam apenas numa diferente maneira de conceber do observador? Não se fundamentarão já, pelo contrário, ou não estarão já préconformados, no próprio modo de ser, na própria estrutura "objetiva" desses dados? A partir desses questionamentos, WELZEL considera que os conceitos científicos não são construções diferentes de um material idêntico, valorativamente neutro, mas reproduções de fragmentos parcelares de um ser ôntico complexo, que é em si mesmo, imanentemente, portador de uma legalidade estrutural e de valores diferenciados, e não receptor passivo dos valores e estruturas produzidos pela ciência. Para o autor, o apriorístico não deve ser interpretado como atividade informadora do entendimento, mas como a estrutura 
que de forma menos manifesta, também aparece. Em verdade, o fundamento maior do finalismo está assentado justamente em um valor: a dignidade da pessoa humana, enquanto princípio de justiça imanente ao Direito e de validade a priori, imponderável e intangível ${ }^{23}$. Dessa noção é extraída a concepção do ser humano como pessoa - capaz de agir livre e responsavelmente -, firmando as bases para a construção do conceito finalista de ação, segundo a qual as normas não podem mandar ou proibir meros processos causais, senão condutas finalisticamente dirigidas (WELZEL, 2004, p. 32).

Hans Welzel (1951, pp. 18 a 24), ao enunciar a doutrina da ação finalista, afirma retomar uma compreensão que remonta à filosofia de ARISTÓTELES (em "Ética à Nicômaco") na Grécia antiga, de São TOMÁs DE AQuINO, na Idade Média, e de Friedrich HEGEL, entre o final do século XVIII e o início do século XIX, mas que havia sido relegada a partir do final do século XIX, quando por influência das ciências naturais ("ciências mecânicas") no campo do Direito a ação passa a ser considerada um processo causal externo ao agente.

Referindo tomar por base os trabalhos do filósofo Richard HöNIGSWALD, dos psicólogos Karl BÜHLER, Theodor ERISMAnN, Erich JAENSCH, Wilhelm Peters e dos fenomenologistas P. F. Finke e Alexander Pfänger (WELZEL, 2004, pp. 27 a 40), WELZEL (1951, pp. 19 e 20) delineia um conceito de ação no qual essa não consiste em um acontecimento meramente causal, mas também finalista, vale dizer, orientado a uma finalidade. A finalidade da ação se baseia na ideia de que o ser humano, amparado em seu conhecimento causal, pode prever em determinada escala as consequências possíveis de uma conduta sua e, com base nisso, refletir sobre objetivos de distintas naturezas, e finalmente dirigir sua atividade seguindo um plano orientado à realização desses objetivos. Em outras termos, respaldado em um conhecimento causal prévio, o sujeito está em condições de conduzir os diversos atos de sua conduta, de tal maneira que governa o

essencial, imanente e material, do próprio objeto. Nessa linha, não cabe ao jurista pôr e dispor livremente dos seus conceitos: deve esforçar-se por compreender a estrutura ôntica do real cuja apreensão jurídica lhe incumbe (LARENZ, 1991, pp. 151 e 152).

${ }^{23}$ Para WelzEL, o respeito à dignidade da pessoa humana, a sua condição de pessoa autônoma, é um princípio material de justiça de validez a priori. Entende o autor que se o direito não quer ser mera força, mero terror, e se quer obrigar aos cidadãos em sua consciência, tem de respeitar a condição do homem como pessoa, como ser responsável. O direito tem já força obrigatória por sua mera positividade, por sua virtude de superar o bellum omnium contra omnes, a guerra civil. Todavia, no caso de uma infração grave do princípio material de justiça, de validez a priori, do respeito à dignidade da pessoa humana, carecerá de força obrigatória e, dada sua injustiça, será preciso negar-lhe o caráter de direito (CEREZO MIR, 2004, p. 15). 
suceder causal exterior para alcançar seu objetivo, determinando esse processo causal de modo finalista ${ }^{24}$.

Para o finalismo, a vontade, enquanto manifestação psíquica capaz de comandar o atuar do ser humano até a consecução de determinados fins, exerce um papel decisivo na conformação do conceito de ação. Essa vontade, com tal função reitora, integra, junto ao movimento muscular, a ação humana, dentro da qual ambos são inseparáveis. E aqui radica a diferença entre uma ação humana e um simples acontecimento natural, uma vez que esse não é orientado conscientemente a alcançar certo fim (NOVOA MONREAL, 1982, p. 41).

O conceito ontológico de ação humana como atividade dirigida a um fim aparece como a primeira estrutura lógico-objetiva indicada por WELZEL, decorrente da análise das missões do direito penal. Considerando que a função do direito penal de proteção de bens jurídicos deve ser alcançada por meio de proibições e mandados acompanhados das respectivas sanções, a capacidade do ser humano de causar ou evitar resultados através de uma conduta finalisticamente dirigida - expressa na estrutura final da ação - converte-se em substrato direto do direito penal e, com isso, a finalidade em sua estrutura lógicoobjetiva primordial (SCHÜNEMANN, 1991 [1], p. 55).

Resultado dessa inovação provocada pelo professor de Bonn foi uma radical modificação dogmática na estrutura do delito, com a transposição do elemento subjetivo do crime (dolo e culpa) para o tipo e a depuração da culpabilidade, que passa a ser puramente normativa; além disso, o conceito de dolo é aperfeiçoado com a retirada da consciência da ilicitude. Com isso, a sistemática jurídica do delito, na concepção finalista, se apresenta da seguinte maneira: o atuar humano como atividade ordenada finalisticamente, o que exige a análise de seu conteúdo subjetivo (vontade), não se tratando de simples processo de

${ }^{24} \mathrm{O}$ conceito de ação utilizado por WELZEL é muito próximo do formulado pelo filósofo alemão Nicolai HARTMANN. Para esse autor, a ação humana só pode ser compreendida como algo finalístico, isto é, algo que necessariamente persegue - desde seu aparecimento, e mesmo antes dele - um determinado objetivo, estranho à própria conduta. Na compreensão de HARTMANN, no desdobramento dessa atividade percorrem-se obrigatoriamente três estágios: primeiramente, o homem antecipa seus objetivos; em seguida, adestra e põe em movimento os meios adequados a obtê-los ou atingi-los; e, finalmente, em uma terceira etapa, alcança sua realização (HARTMANN, 2011, pp. 230 e 231; TAVARES, 1980, pp. 55 e 56; NOVOA MONREAL, 1982, p. 76; RoXIN, 1997, p. 239). Apesar de refutar a afirmação de que sua doutrina jurídico-penal teria origem na filosofia de HARTMANN (WELZEL, 2004, pp. 27 a 40), WELzEL (2004, pp. 29 e 36; 1974, p. 11) reconhece que na estrutura de ação daquele autor encontrou a confirmação e o aclaramento de sua própria concepção, anteriormente desenvolvida, o que o levou, inclusive, a substituir o termo "intencionalidade", inicialmente utilizado em seus escritos, por "finalidade", expressão que ficou consagrada em sua obra, mas que foi proposta primeiramente por HARTMANN. Nas palavras de WElzEL (1974, p. 11): "Em lugar de intencionalidade, usei em 1935, aderindo a Nicolai HARTMANN, a palavra 'Finalität' (finalidade), para assinalar 'a peculiaridade incomparável da vontade como fator causal', 'capaz de antecipar mentalmente, dentro de certos limites, as possíveis consequências de sua ação e, assim, de regular, de acordo com o sentido, sua intervenção no mundo'. Pensei haver encontrado desta maneira, uma designação muito mais clara que a anterior ('intencionalidade')". 
natureza causal (objetivo e "cego"); a tipicidade inclui elementos objetivos (tipo objetivo) e elementos subjetivos (tipo subjetivo); a ilicitude tem conteúdo objetivo e subjetivo, sendo o injusto pessoal (desvalor da ação e desvalor do resultado); e a culpabilidade é normativa pura. Nessa concepção de culpabilidade, o juízo de reprovação leva em consideração a imputabilidade (ou capacidade de culpabilidade), a consciência atual ou possível da antijuridicidade e as circunstâncias do fato que permitem a apreciação da inexigibilidade de obediência ao Direito.

Com as mudanças desencadeadas na estrutura do delito em virtude do finalismo em especial, a transposição do dolo e da culpa para o tipo penal -, a culpabilidade deixa de conservar em seu conteúdo a parte subjetiva do fato, passando a constituir-se unicamente de elementos normativos. Assim, na teoria welzeliana, todo o objeto de reprovação passa a se localizar no injusto, enquanto que na culpabilidade se encontram as condições que permitem realizar tal juízo sobre o autor.

A culpabilidade, na concepção finalista, é compreendida como um puro juízo de reprovação sobre o autor, por não haver se omitido da ação antijurídica, quando podia tê-lo feito. Essa reprovabilidade assenta-se, precisamente, no poder do autor de não ter agido antijuridicamente, o qual está intimamente relacionado à vontade, de maneira que o que se reprova no juízo de culpabilidade é a configuração da vontade, expressa no fato antijurídico (WELZEL, 1956, pp. 148 e 149).

Na formulação welzeliana, a colocação do poder no âmago da culpabilidade não determina a prescindibilidade de investigação acerca de seu conteúdo, de maneira que a configuração da vontade está relacionada a certos pressupostos, por meio dos quais é possível verificar se o autor teria podido motivar-se conforme o Direito. Apenas com a demonstração de tais pressupostos se viabiliza a reprovação.

Conforme precisamente identifica Juarez TAVARES (1980, p. 74), dois são esses pressupostos. O primeiro, que o autor seja capaz de motivar-se de acordo com a norma. O segundo, que esteja em condições concretas ou em situação de motivar-se de acordo com ela. Àquele diz respeito à imputabilidade, enquanto esse se refere à consciência do injusto. E ambos associam-se a uma estruturação maior, ligada à problemática da liberdade de vontade como fundamento da responsabilidade penal. 
No modelo de Welzel (1956, pp. 153 a 163), o problema do livre-arbítrio assume três aspectos diferentes, mas interligados: o antropológico, o caracteriológico e o categorial.

$\mathrm{O}$ aspecto antropológico tem por ideia central, formada a partir de pesquisas de psicologia animal ${ }^{25}$, que o homem, ao contrário das demais espécies, tem por traço característico uma grande deterioração de formas inatas de conduta, como os instintos. Assim, à diferença dos outros animais, o ser humano não herda um sistema de ações, próprias da espécie e adequadas a sua sobrevivência e conservação, mas cada um de seus espécimes tem de formá-lo, por meio do aprendizado e da experiência, para que possa sobreviver.

Dessa maneira, para compensar tal deficiência, o ser humano se apresenta como detentor de um pensamento racional, ordenado categoricamente, que o torna capaz de responsabilidade (ou predisposto à autorresponsabilidade) por suas ações e omissões. No plano existencial, portanto, o homem se revela caracterizado negativamente por sua ampla liberdade com relação às formas instintivas e inatas de comportamento, e positivamente pela capacidade e missão de descobrir, por si próprio, o modo de conduta correto, por meio de atos conscientes (WELZEL, 1956, pp. 153 a 155).

A desintegração das formas inatas de conduta e a consequente caracterização do homem como ser inteligente e responsável levam a uma estrutura psíquica (anímica) do ser humano composta de três estratos, que compõem o aspecto caracteriológico da problemática da liberdade de vontade.

O estrato profundo (ou baixo), é constituído pelos impulsos vitais de autoconservação ou de conservação da espécie, e também pelos afetos, pelos desejos e pelas inclinações, tendências e interesses relacionados ao "Eu" que conduzam o homem a uma ação a ponto de torná-lo uma vítima passiva dos próprios impulsos. Acima desse está o estrato do "Eu", que compreende os atos do pensamento amparados em fundamentos lógico-objetivos e volitivos, e que atua dirigindo e regulando os impulsos conforme parâmetros de sentido e de valor. E localizado entre os estratos profundo e do "Eu" encontra-se o estrato intermediário da personalidade, que funciona como um reservatório de decisões executadas anteriormente e convertidas em posicionamentos internos inconscientes, configuradores do caráter da pessoa.

\footnotetext{
${ }^{25}$ Com destaque para o trabalho do zoólogo austríaco Konrad LoRENZ, notadamente sua obra "Zeitschrift für Tierpsychologie", de 1963.
} 
Esses três estratos estão interligados por subcamadas, e a partir de sua integração é formada a atitude responsável. Nesse sentido, no ser humano a decisão por determinada ação não aparece como o resultado de um impulso ou instinto que predominou sobre outros, como ocorre nas demais espécies animais. Considerado o papel regulador do estrato do "Eu", os impulsos atuam como meros motivos de agir, sobre os quais, aliados a critérios lógicos e valorativos, se fundamenta a escolha da vontade.

Disso decorre que os atos do "Eu" não transcorrem no âmbito da causalidade, mas no plano do sentido: as razões de pensamento e de vontade são os fundamentos materiais isto é, os não causais - sobre os quais se apoiam, segundo o sentido, os atos de pensamento e de vontade. O plano de sentido, contudo, não está restrito, sempre, ao estrato do "Eu". Há situações em que o sentido já está determinado, pois fora decidido anteriormente, em conjunturas passadas, tendo a partir de então se incorporado ao homem, no estrato da personalidade, como seu posicionamento interno. Nesses casos, o papel do estrato do "Eu" é de simples atualizador daquelas escolhas que já foram realizadas e estão armazenadas no inconsciente (WELZEL, 1956, pp. 156 e 157).

No aspecto categorial, por fim, considerando a delimitação existencial do problema da liberdade de vontade e os mecanismos de tomada de decisão, apresentados pelos aspectos antropológico e caracteriológico, indaga-se: como é possível ao ser humano configurar sua atividade por meio de uma direção orientada pelo sentido e ser responsabilizado pela adoção de uma decisão incorreta em lugar da correta?

$\mathrm{Na}$ resposta à questão proposta, o indeterminismo tradicional é afastado, porque incompatível com a ideia de responsabilidade: se o ato de vontade do homem não é determinado por coisa alguma, então o ato posterior ao da vontade não pode estar relacionado, de qualquer forma, com o anterior, vez que, por coerência, esse também não está determinado por algo. Assim, se um estado do sujeito não possui qualquer relação com o antecessor, os atos de vontade são convertidos em uma sucessão absolutamente independente de choques individuais no tempo, pelos quais o indivíduo não pode ser responsabilizado.

Na mesma direção, o determinismo tradicional, segundo o qual existe apenas uma forma de determinação - compreendida desde o começo dos tempos modernos pela noção de causalidade (ou monismo causal) -, também não responde satisfatoriamente a questão colocada. Aqui, a reprovação ao sujeito por ter adotado uma decisão equivocada, em vez 
da correta, não pode ser feita, considerando que todas as escolhas - independentemente se acertadas ou não - já estão fixadas, necessariamente, desde o princípio.

Em face das insuficiências teóricas apontadas, a resposta do finalismo ao questionamento posto procura superar tanto o indeterminismo, quanto o determinismo absolutos, adotando uma posição conciliatória, na qual se admite a estrutura causal dos atos do pensamento, mas se reconhece, por outro lado, a existência determinante de fundamentos inteligíveis. Nesse contexto, o livre-arbítrio é concebido como a capacidade de poder determinar-se de acordo com o sentido, apresentando-se como um ato de liberação da coação causal dos impulsos voltado à autodeterminação conforme dada finalidade (WELZEL, 1956, pp. 157 a 163).

A culpabilidade welzeliana assenta-se, pois, na ausência de autodeterminação conforme o sentido, em um sujeito que tinha capacidade para tanto. Nessa formulação, portanto, não é relevante a decisão em favor do mal, mas a omissão com relação à condução por impulsos contrários ao valor. Disso decorre que a culpabilidade incide sobre a formação da vontade: o agente é reprovado por não haver reprimido os impulsos adversos e se orientado conforme o sentido (WELZEL, 1956, pp. 161 e 162).

Como certeiramente observa Juarez TAVARES (1980, pp. 78 e 79), a introdução na culpabilidade do conceito de omissão de se autodeterminar de acordo com o sentido e valor, consubstanciando um juízo negativo de aferição, conduz inquestionavelmente a uma responsabilização amparada no dever jurídico: o agente deixa de cumprir o dever e, por esse motivo, é reprovado pela ordem jurídica. Considerando os aspectos antropológico, caracteriológico e categorial, verifica-se que o descumprimento desse dever de regulação e condução dos impulsos conforme o sentido pode ocorrer tanto em função de um defeito momentâneo do estrato do "Eu" - que não foi capaz de, concretamente, dirigir adequadamente as tendências instintivas -, quanto em razão de uma permanente máformação da vontade. Com relação a essa hipótese, próxima de um direito penal do autor, é utilizada por WeLzEL (2004, p. 151) para caracterizar a essência da culpabilidade nos crimes culposos, notadamente nas hipóteses de culpa inconsciente ${ }^{26}$.

\footnotetext{
${ }^{26} \mathrm{O}$ professor de Bonn afirma que a culpabilidade pode ter origem na falta - ou na estrutura defeituosa - do estrato da personalidade. Este seria o caso do delinquente habitual, que não haveria assimilado suficientemente as normas de conduta social, ou as teria perdido em razão de sua desarranjada condução de vida. Seria o caso, também, do delinquente passional, que teria deixado crescer dentro de si a paixão, ou não teria desenvolvido inibições contrárias a impulsos dessa natureza. E, outrossim, seria a hipótese do sujeito que pratica um fato delituoso por negligência ou imprudência, uma vez que não teria desenvolvido adequadamente a atenção inconsciente a toda sorte de riscos. Em todas essas situações, a culpabilidade do fato individual teria raiz em um elemento permanente (da psique do sujeito): a estrutura defeituosa do estrato
} 
Essa formulação, identificada com a culpabilidade do autor ${ }^{27}$ e intimamente ligada à culpabilidade de caráter ${ }^{28}$, particularmente à culpabilidade pela conduta de vida ${ }^{29}$, rendeu severas críticas ao penalista alemão. Dentre elas, a de que permitiria o regresso a um direito penal da vontade, perverso por suas consequências arbitrárias, em um momento em que o modelo de responsabilização criminal já estaria caracterizado pela indiferença em relação à formação da personalidade ou do caráter do autor. Nessa linha, assenta Juarez TAVARES (1980, pp. 79 e 80) que a culpabilidade deve, exclusivamente, basear-se no fato antijurídico, atribuído pessoalmente ao autor, no qual assume relevância o critério regulador da exigibilidade (fundamento objetivo) de uma conduta adequada à norma. Assim, conforme sustenta o professor do Rio de Janeiro, a reprovação deve recair precisamente sobre o agente, por haver esse, volitivamente (com dolo) ou sem o cuidado exigido (com culpa), praticado uma conduta antijurídica, conquanto pudesse, consideradas suas possibilidades concretas e reais, atuar de outra forma.

O juízo de culpabilidade - que de acordo com os parâmetros acima delineados deve ser sempre um juízo positivo de reprovação sobre o autor de um fato antijurídico -, tem como pressuposto existencial a possibilidade de autodeterminação do agente, no sentido de poder atender ao dever jurídico concebido por WELZEL, a qual é representada pela capacidade abstrata de culpabilidade (imputabilidade), bem como pela capacidade concreta de estruturação da vontade conforme o direito (TAVARES, 1980, pp. 80 e 81).

da personalidade, que corresponderia a um defeito reprovável do caráter - a denominada "culpabilidade do autor" (WELZEL, 2004, p. 151).

$27 \mathrm{O}$ direito penal moderno é, basicamente, um direito penal do fato. Decorrência desse modelo é a estruturação de tipos penais que, seguindo as exigências do princípio nullum crimen, nulla poena sine lege, descrevem um modelo de conduta proibido, em vez de um tipo criminológico de autor. Nem sempre, porém, foi assim, de maneira que ao longo da história, várias correntes, de origem e propósitos diversos, buscaram colocar o agente, com seu caráter, com sua personalidade, no cerne do problema penal, com inteira precedência lógica sobre o fato, considerado esse mero fenômeno sintomático, ou simples ponto de partida para a aplicação da pena criminal. Essas distintas teorias, de um modo geral, podem ser identificadas como direito penal do autor. Intimamente ligada a uma concepção de direito penal do autor está a culpabilidade do autor, segundo a qual culpável não é o fato do agente, mas o próprio agente, quer por seu modo de ser, quer por seu caráter, etc. (TOLEDO, 2008, pp. 235 a 238).

28 A culpabilidade de caráter tem por pressuposto que o ser humano se torna aquilo que é por um comportamento voluntário na sua origem, uma vez que a escolha entre o vício e a virtude, em cada conduta, depende exclusivamente do indivíduo. Na linha desse raciocínio, pela prática (reiterada) de certas ações, o sujeito acaba por formar um caráter desse mesmo gênero de ações, o que, segundo essa concepção, permite a responsabilização pelo que se é, ou pelo modo de ser que se construiu (TOLEDO, 2008, pp. 238 e 239).

29 A culpabilidade pela conduta de vida foi a primeira elaboração de uma culpabilidade de caráter. Proposta por MEZGER (1958, pp. 193 e 251), verifica-se quando o agente forma o caráter, em certas circunstâncias (como, por exemplo, a aquisição de maus hábitos que não permitem a distinção entre o lícito e o ilícito), de modo a alcançar uma posição censurável de "inimizade ao direito". Nessa conjuntura, o direito penal, sob pena de ficar inteiramente desarmado diante de delinquentes perigosos, deve admitir em determinados casos, de acordo com essa formulação, um agir doloso e culpável sem a consciência atual do injusto, quanto essa falta de consciência puder ser atribuída ao agente em razão de sua culpa na formação do caráter, pela condução de sua vida (TOLEDO, 2008, p. 239). 
A despeito de sua posição central no conteúdo material da concepção normativa pura da culpabilidade, a liberdade de vontade é assumida por WELZEL como premissa, de maneira que passa ao largo do finalismo explicar de que forma ela atua no processo de tomada de decisão. A esse respeito, JESCHECK (2003, pp. 5 e 6) observa que inobstante restrinja o conceito de culpabilidade a parte da responsabilidade do autor por sua determinação antijurídica, WELZEL não explica como pode fundamentar-se a responsabilidade do culpável por sua decisão de cometer o fato. Para aquele autor, se revela impossível conhecer, a partir da teoria welzeliana, de que forma a pessoa evita o delito e utiliza, de fato, seu autocontrole com a finalidade de atuar conforme o Direito. Nas palavras do professor de Friburgo, "esse continua sendo o 'mistério' do livre-arbítrio" (JESCHECK, 2003, p. 6).

Com a problemática do livre-arbítrio não resolvida, o conceito de culpabilidade finalista entrou em crise na moderna ciência do direito penal. A inviabilidade de comprovação empírica da liberdade de vontade do ser humano - e, particularmente, a indemonstrabilidade da possibilidade de o agente ter agido de outro modo, em conformidade à norma, na situação concreta -, constatada pela doutrina penal, revelou a insuficiência teórica da concepção normativa welzeliana e a necessidade de busca por novas formulações.

\subsection{A crise do conceito de culpabilidade normativa}

Do desenvolvimento da teoria do delito e, particularmente, da evolução no conceito de culpabilidade, verifica-se que a formulação que se consagrou na doutrina penal acerca daquele elemento do crime foi a concepção normativa, consistente, basicamente, em um juízo de reprovabilidade dirigido ao sujeito por sua conduta típica e antijurídica. A despeito de largamente aceita pelos penalistas, essa definição exprime apenas um conceito formal de culpabilidade, que não permite dele sejam extraídos os fundamentos (MACHADO, 2010, p. 92; BRUNONI, 2010, p. 167).

A esse respeito, Claus Roxin (1997, p. 798), ao tratar da determinação do conteúdo da culpabilidade em direito penal, observa, expressamente, que a concepção normativa só afirma que uma conduta culpável há de ser reprovável, sendo, portanto, de natureza absolutamente formal, por não responder à questão relativa a de quais pressupostos materiais depende a reprovabilidade. 
Nessa mesma linha, Urs KINDHÄUSER (2011 [2], p. 68) chega, inclusive, a tratar a reprovabilidade como culpabilidade formal, por entender que a ideia representada por tal concepção não submete à discussão seus fundamentos materiais. Para o autor, o que há especificamente de jurídico-penal naquele conceito é que o objeto da reprovação é a infração de uma norma penalmente sancionada, permanecendo sem resposta o porquê de se penalizar a ausência de motivação para portar-se conforme o Direito e, além disso, por qual razão o autor deveria ter motivado-se para agir nesse sentido.

Diante dessa constatação, isto é, da inaptidão da teoria normativa para precisar em que consiste, substancialmente, a reprovação pessoal, e do consequente risco de deixar a mercê do arbítrio judicial a decisão (casuística) sobre o conteúdo do juízo de censura, a doutrina penal passou a se dedicar à busca do substrato material da culpabilidade.

Ainda na conjuntura do finalismo, no contexto do aperfeiçoamento de uma culpabilidade psicológico-normativa para uma culpabilidade normativa pura, WELzEL (2004, pp. 126 a 129), ao elaborar a estrutura do delito de sua teoria, fundamenta o juízo de reprovação do autor de um injusto penal no "poder agir de modo diverso", isto é, a censura é dirigida ao sujeito por não ter atuado conforme a norma, apesar de haver podido agir nesse sentido. A concepção finalista da culpabilidade tem por objeto primário da reprovabilidade a vontade (livre) do autor - e, a partir dela, a ação como um todo -, em razão de se considerar que somente aquilo que o ser humano (considerado individualizadamente, na situação concreta e específica) pode realizar voluntariamente é passível de ser censurado como culpabilidade.

Essa concepção, alicerçada profundamente na possibilidade de autodeterminação livre e responsável do ser humano, foi objeto de severas críticas por parte de parcela considerável da doutrina penal, porque, para além de assentar-se em um pressuposto absolutamente polêmico e problemático - que constitui questão não solucionada nas mais diversas áreas do saber -, o livre-arbítrio, fundamenta-se em critério indemonstrável empiricamente: a possibilidade de uma pessoa, em determinada situação, ter atuado de maneira diferente daquela que efetivamente realizou.

As críticas à culpabilidade finalista foram sistematizadas por Karl ENGISCH em sua obra "Die Lehre von der Willensfreiheit in der Strafrechtsphilosophischen Doktrin der Gegenwart" (ou "A teoria da liberdade de vontade na atual doutrina filosófica do direito penal"), publicada em 1963. Na principal delas, o autor argumenta que não é viável verificar experimentalmente se em uma situação concreta o sujeito poderia ter agido de 
modo diverso, uma vez que é impossível trasladar a pessoa, com a mesma e exata individualidade de então, a uma nova e idêntica conjuntura de fato. Notadamente porque, estando o ser humano dotado de memória, ainda que seja submetido novamente a um contexto fático igual ao de outrora, nesse segundo momento já não será mais a mesma pessoa de antes, pois terá lembranças e experiências adquiridas da situação anterior - de suas circunstâncias, consequências, repercussões psíquicas etc. (ENGISCH, 2008, pp. 75 a 77).

Além dessa, outra crítica de ENGISCH à WELZEL se destaca, relacionada à compreensão do formulador da culpabilidade finalista de que a vontade do ser humano só é voltada ao bem, já que o agir é a libertação da coação causal, e vontade má não é livre, porquanto atrelada aos impulsos contrários ao valor. Para ENGISCH, a tese de WELZEL de que a ação valorada é uma ação determinada conforme ao sentido, ao passo que a ação desvalorada (culpável) representaria uma sucumbência aos instintos causais, de maneira que a culpabilidade seria conceituada como a falta de autodeterminação conforme ao sentido em um sujeito capaz de determinar-se, significa, no limite, que a vontade culpável é uma vontade não livre. Em razão dessa inconsistência teórica, o professor de Munique entende que a culpabilidade deve ser preenchida de conteúdo não pelo "poder agir de outro modo", mas pelo caráter (ou personalidade) do sujeito - porque daí emanaria o injusto penal -, de modo que a conduta criminosa seja reprovada ao sujeito considerando sua conduta de vida - ainda que essa importe tão somente como raiz (determinante causal) do fato delituoso, e não de um modo geral (RODRÍGUEZ, 2014, pp. 219 a 223) ${ }^{30}$.

Vinte anos mais tarde, em 1985, Roxin publica o artigo "Was bleibt von der Schuld im Strafrecht übrig?" (ou "O que resta da culpabilidade em direito penal?"), em que verifica já ser pacífico, àquela altura, o entendimento de que não é possível provar com

\footnotetext{
${ }^{30}$ Em face das críticas de ENGISCH, e de sua compreensão determinista de que o comportamento humano é causalmente determinado pelo caráter, WELZEL apresenta algumas respostas. Na mais contundente delas, o professor de Bonn discorda do entendimento de que a ação segundo a própria personalidade operaria de modo determinístico. Em sua visão, se assim fosse, haveria que se aplicar a mesma ideia ao juiz e ao próprio legislador, o qual poderia se escusar de ter feito uma lei defeituosa por agir de acordo com sua personalidade. Para o autor, todo o saber apreendido tem um objeto, vale dizer, depende da interação de um objeto conhecido com o sujeito cognoscente, e essa interação não se pode confundir com a relação de causalidade das ciências naturais. Assim, ressalta a diferença entre decidir conforme ao sentido, reconhecendo o objeto, e a relação determinista, na medida em que aquela orientação, que depende do sujeito, não seria cega ou automática. Opondo-se aos argumentos de ENGISCH, WELZEL reafirma a necessidade do livre-arbítrio para a imputação penal assentando que conquanto seja o curso do pensamento determinado pelo objeto do conhecimento, o ato de conhecimento é livre de determinantes causais. E, de modo semelhante ao processo de aquisição do conhecimento, a formação da vontade voltada ao agir dotar-se-ia tanto de elementos objetivos, como também segundo seu conteúdo de sentido, seu significado para a configuração da vida (RODRÍGUEZ, 2014, pp. 224 e 225).
} 
métodos científico-empíricos que o autor, no momento do fato, poderia haver atuado de modo distinto ao efetivamente levado a efeito. Disso conclui que se o "poder atuar de outro modo" é indemonstrável como fato real, tampouco é possível determinar a existência de uma culpabilidade no sentido da doutrina tradicional ${ }^{31}$, revelando-se necessário atribuir-lhe uma nova conceituação ${ }^{32}$ (RoXIN, 1986, p. 671).

Dessa inconsistência teórica identificada pela doutrina, toda a estrutura conceitual do direito penal parece desmoronar, a partir da seguinte verificação: o direito penal pressupõe a pena; a pena, por sua vez, pressupõe a culpabilidade; e essa - com o fundamento material do finalismo - pressupõe a liberdade de vontade, a qual é, de seu turno, indemonstrável (GIMBERNAT ORDEIG, 1990, p. 158). Diante dessa dúvida acerca da existência do livre-arbítrio, surge um dilema, que passa a inquietar a doutrina penal: ou se renuncia à ideia do "poder agir de modo diverso" como fundamento da pena, ficando-se, assim, sem base para contestar que o sistema penal trate o ser humano como um mero objeto; ou se adere a tal ideia, com a consequente admissão de que o Estado pune seus cidadãos lastreado em um fundamento inseguro, indemonstrável e, portanto, inaceitável isto é, sem fundamento algum (VIVES ANTÓN, 2010, p. 49).

Crítica de outra natureza também é manifestada contra a concepção normativa da culpabilidade: o caráter moral e ético que seria próprio do juízo de reprovação. Basicamente, para os doutrinadores dessa corrente, são duas as dimensões em que essa vinculação entre o direito penal e a moral não se justifica: de um lado, porque em uma sociedade pluralística e que garante o respeito às liberdade públicas, o Estado (Democrático de Direito) não tem legitimidade para se elevar moralmente sobre o cidadão, realizando juízos éticos acerca de sua conduta; de outro, porquanto não se pode formular,

\footnotetext{
${ }^{31}$ Segundo o doutrinador alemão, o convencional direito penal da culpabilidade se baseia em quatro ideias distintas, mas estruturadas uma sobre a outra, a saber: $(i)$ o delinquente viola a lei penal, apesar de estar em suas mãos comportar-se de outro modo, isto é, de forma ajustada àquela lei; (ii) esse comportamento, penalmente antijurídico, livremente eleito, estabelece as bases de uma reprovação moral e, com isso, da culpabilidade do autor - culpabilidade é reprovabilidade; (iii) a reprovabilidade do fato outorga ao Estado a legitimação para retribuí-lo mediante a causação de um mal - hoje, geralmente, uma pena privativa de liberdade ou uma pena pecuniária -, de forma correspondente à medida da culpabilidade; e (iv) a pena retributiva da culpabilidade é o meio mais adequado para a repressão de modalidades de comportamento socialmente danosas, não evitáveis de outra maneira (ROXIN, 1986, p. 671).

${ }^{32}$ De acordo com o professor de Munique, diante das dificuldades teóricas do conceito de culpabilidade, parece lógico abandoná-lo, para assentar o direito penal sobre uma base diferente. Todavia, esse entendimento, sustentado por parte da doutrina penal, não é compartilhado por RoxIN. Na opinião do autor, a despeito das justificadas críticas a sua configuração tradicional, a culpabilidade tem contribuído de modo decisivo a moldar o direito penal em contornos mais humanos e ajustados ao Estado Democrático de Direito. Nesse sentido, para abandonar o princípio da culpabilidade, dever-se-ia demonstrar que suas funções serão cumpridas tão bem - ou ainda melhor - por outras categorias jurídicas (RoXIN, 1986, p. 673).
} 
de forma responsável, uma censura contra pessoa que se conhece de modo tão seletivo e rudimentar, situação do juiz perante o acusado em um processo criminal (BRUNONI, 2010, p. 149).

Na direção do primeiro argumento, Eugenio Raúl ZAFFARONI (1998, pp. 269 e 270) salienta que desde que se abandonou o conceito descritivo ou psicológico da culpabilidade e essa passou a ser concebida normativamente, observou-se uma acentuação eticizante do direito penal, de maneira que se tornaram nebulosos alguns limites entre a moral e o direito, o pecado e o delito, a correção e a pena, o que levou a um comprometimento da função garantidora do discurso jurídico-penal. Em face dessa realidade, e para tentar salvar a culpabilidade de uma completa imersão ética, explica o penalista argentino que um setor doutrinário passou a sustentar que a culpabilidade consiste em uma reprovação jurídica, e não ética - ou puramente ética.

Todavia, na concepção do professor de Buenos Aires, na medida em que a culpabilidade seguiu sendo reprovabilidade, não pôde livrar-se de componentes éticos, considerando que uma censura sem contornos desse tipo é uma contradictio in adjectio. Assim, para o autor, a seletividade operativa do sistema penal - e o uso da pena como instrumento reprodutor da violência e legitimador de um exercício de poder - revela claramente que os traços éticos, que constituem a essência da reprovação da culpabilidade, não são mais do que meras racionalizações, com o que o juízo de censura resta deslegitimado.

Nesse mesmo sentido, Nilo BAtista (2009, pp. 12 a 19) afirma que muitos penalistas procuram desvencilhar o juízo de reprovação de seu conteúdo moral, o que, a seu ver, não é possível. Para o autor, toda e qualquer reprovação, ainda que, por metonímia, endereçada à conduta, ao injusto, à infidelidade ao direito ou a qualquer produto teórico similar, dirige-se na verdade ao sujeito do conflito criminalizado, vale dizer, ao acusado, estando, por essa razão, atrelada aos domínios da reflexão moral. Acrescenta, ainda, que a invocação moralista que a ideia de reprovação implica leva o "escracho do jornalismo policialesco" para as decisões judiciais, de maneira que o "comportamento ético" do acusado é questionado, mencionando-se seu "ato indigno" ou sua "infração repugnante"; ou, ainda pior, se percebe no acusado "uma distorção psicológica, rompendo os freios da moral e da religião" ou mesmo uma "personalidade deformada, índole perversa". 
E, na linha da segunda dimensão da crítica ao caráter moral do juízo de reprovação, o professor do Rio de Janeiro assere que no Estado de Direito, em cuja Constituição está incorporado o princípio da autonomia moral da pessoa, conquanto o juiz certamente possa constatar a culpabilidade do acusado, e nos limites dessa constatação aplicar-lhe a pena, não tem ele o direito de censurar, de repreender o condenado, e sempre que o fizer estará atuando com abuso de poder. Arremata seu argumento apresentando a seguinte (provocativa) questão: de que adiantaria a Constituição proclamar o princípio da autonomia moral da pessoa, para depois aparecer um funcionário público togado, de dedo em riste, para cabalmente negá-lo ao censurar o acusado?! Na opinião do doutrinador, outorgar ao juízo de culpabilidade o sentido de reprovação atraiu um moralismo vulgar inadmissível no Estado de Direito erigido a partir da dignidade da pessoa humana, cuja pedra angular reside em sua autonomia moral. Isso por considerar que quando o poder punitivo se habilita a partir de uma consideração moral sobre o sujeito, está-se na verdade penalizando o ser, isto é, praticando-se uma culpabilização de autor não muito diferente daquela baseada na perigosidade, o que representaria um regresso aos tempos da Inquisição.

A postura da doutrina no contexto da crise da concepção normativa da culpabilidade não se limitou a apontar suas incongruências teóricas, mas suscitou, também, uma série de proposições com vistas a elaborar uma estrutura de responsabilização penal de caráter pessoal que solucionasse os problemas identificados a partir das críticas formuladas. Essas várias propostas podem ser divididas em quatro grandes grupos, de acordo com sua natureza, a saber: $(i)$ as que rechaçam a culpabilidade e defendem a instituição de outro critério em seu lugar; (ii) as que, a despeito das críticas à culpabilidade, sustentam a manutenção de seu conceito, mas com um substrato material fundado em critérios extrínsecos; (iii) as que, conquanto compartilhem das críticas a culpabilidade, também manifestam-se favoravelmente à sua conservação na estrutura do delito, mas com complementações e revisões internas; e (iv) a posição integradora de ROXIN (BUSTOS RAMíReZ; Hermozabal MalaréE, 1999, pp. 319 e 320).

\subsection{Panorama atual: alternativas teóricas à culpabilidade normativa}

3.5.1. Responsabilização penal sem culpabilidade: posições negacionistas 


\subsubsection{Determinismo e a responsabilização penal fundada na defesa social} por meio da pena: os percussores Enrico FERRI e Pedro LESSA

As posições negadoras do conceito de culpabilidade, que sustentam uma estrutura de delito sem esse elemento, existem na doutrina penal desde o século XIX. Os negadores ou "negacionistas" - fundam seu entendimento na concepção filosófica do determinismo, de que se tratará com mais profundidade adiante no capítulo "4.4.", mas cujo preceito fundamental é o da negação do livre-arbítrio humano, isto é, a ideia de que o ser humano não é livre em sua atuação, na medida em que valores externos ou condicionantes internas o motivam a agir de um modo e não de outro, ainda que, de uma perspectiva subjetiva, sua impressão seja a de que atua livremente. Decorre dessa concepção que não há culpabilidade não apenas nos casos de anomalias psíquicas - ou motivacionais - ou de imaturidade do sujeito, mas em todas as situações de "normalidade". Nessa linha, para que haja punição é preciso que se verifiquem outros critérios, como a personalidade perigosa do indivíduo, ou responsabilidade subjetiva por razões de necessidade de prevenção, não sendo relevante se o sujeito é culpável moral ou juridicamente pelo fato (LuZÓN PEÑA, 2012, pp. 7 e 8 ).

Representante mais notável dessa corrente teórica, Enrico FERRI sintetizou em seus estudos a crítica da Escola Positiva ${ }^{33}$ ao livre-arbítrio como premissa da responsabilidade

\footnotetext{
${ }^{33}$ A Escola Positiva foi iniciada com os estudos do médico italiano Cesare LOMBRoso, a quem é atribuída a mudança de enfoque do fenômeno criminal, de ente jurídico a fato observável - em seu caso, desde a perspectiva do delinquente. Nessa linha de observação da realidade, destaca-se também Raffaele GAROFALO, criminólogo italiano cujo trabalho busca analisar o delito não como um ente jurídico, mas como um fenômeno natural ou social. No entanto, a despeito das contribuições de ambos, o mais influente dos membros da Escola Positiva no direito penal de sua época - e também até os dias de hoje - é Enrico FERRI, estudioso que logrou conjugar a direção antropológico-biológica de LOMBROSO com uma concepção sociológica do delinquente, em conexão com as necessidades sistemáticas exigidas pelo pensamento penal tradicional. LOMBROSO, GAROFALO e FERRI, em razão da natureza de suas pesquisas e da contribuição de sua produção científica, são considerados os pais da criminologia e os mais proeminentes representantes da Escola Positiva, a qual, pela inovação de seus postulados, significou uma verdadeira revolução no âmbito do direito penal. Durante muito tempo seus partidários desenvolveram uma luta de escolas com os representantes da Escola Clássica, situação que arrefeceu apenas com a aceitação na doutrina do modelo da "dupla via", posição eclética entre ambas as correntes teóricas, que inclui na estrutura do sistema penal tanto a culpabilidade e a pena, quanto a perigosidade e a medida de segurança. Os fundamentos teóricos da Escola Positiva podem ser resumidos nas seguintes ideias: $(i)$ às ciências penais, especialmente ao direito penal, deve ser aplicado o método das ciências naturais e, portanto, as leis que o regem, notadamente a da causalidade; assim, a observação do delinquente deve realizar-se desde parâmetros antropológicos e sociais, que fundados na relação de causa e efeito logrará acumular, a partir da técnica estatística, dados suficientes para o alcance dos princípios que regem o homem delinquente; (ii) trasladada a atenção do delito como ente jurídico ao delinquente como realidade do mundo natural, aquele perde importância, sendo considerado mera
} 
penal. Recordando que tanto os penalistas da Idade Média, quanto os de épocas posteriores, exigem como condição necessária de imputabilidade a "normalidade de consciência e inteligência", assim como a "liberdade de escolha voluntária", o criminólogo italiano afirma que, considerando-se a indemonstrabilidade de sua existência, não pode a (crença à) liberdade de vontade do ser humano condicionar a justiça penal (FERRI, 1933, p. 204).

Para o autor, partidário do determinismo, o delinquente é um sujeito determinado a praticar crimes, de modo que só podem ser criminosas aquelas pessoas que padecem de alguma anormalidade (FERRI, 1933, p. 194). Em face disso, sustenta que cabe ao Estado atuar em defesa da sociedade, com medidas repressivas adequadas à readaptação social, por entender que o ser humano é sempre responsável por todo ato que realiza, pois vive em sociedade, recebendo a proteção e os meios necessários para o desenvolvimento de sua personalidade, devendo, em contrapartida, sofrer as restrições - e eventuais sanções - que asseguram um mínimo de disciplina social, sem a qual não é possível a vida em comunidade (FERRI, 1933, p. 225).

Lastreado nesses fundamentos, notadamente no de que a justiça penal não se assenta no indivíduo e no livre-arbítrio, mas na defesa social, FERRI (1933, pp. 266 e ss.) defende que o critério para ponderar as medidas repressivas que tornem efetiva aquela finalidade não pode ser a culpabilidade, mas sim a perigosidade, isto é, a capacidade para delinquir, representada pela probabilidade de repetição de ações criminosas - o que implica considerar, por um lado, a "temibilidade" do sujeito e, por outro, sua readaptabilidade social.

Em síntese, o posicionamento do autor italiano pode ser resumido em uma dupla vertente: primeiro, que o livre-arbítrio é ilusório; segundo, e com maior relevância, que a

expressão da personalidade desse; (iii) o livre-arbítrio é negado - e, com isso, toda a fundamentação filosófica da Escola Clássica -, de maneira que o delinquente é considerado um ser anormal, determinado à prática do delito; consequência disso é o rechaço ao conceito de imputabilidade, uma vez que esse supõe a "normalidade" do delinquente e a exclusão da responsabilidade penal de sujeitos "anormais"; (iv) o delinquente, em razão de sua anormalidade, é tomado como um ser perigoso; e essa perigosidade passa a ser o critério de aplicação da lei penal, em detrimento da entidade objetiva do delito; $(v)$ frente ao indivíduo perigoso, cuja perigosidade se medirá pelo grau de readaptabilidade social, a sociedade se defende por meio de sanções destinadas à reinserção daquele na sociedade, caso isso seja possível; com isso, desaparece a distinção entre pena e medida de segurança, já que aquela não pode mais ter como finalidade a retribuição, mas apenas a readaptação, tal como a medida de segurança; (vi) a defesa social frente ao sujeito perigoso pode ser anterior ao delito, já que é suficiente para a aplicação da sanção penal que se demonstre, de qualquer modo, sua temibilidade, isto é, sua capacidade para cometer delitos - ou, em outras palavras, sua falta de adaptação social -; trata-se, pois, das denominadas medidas pré-criminais; e (vii) os cárceres devem converter-se em estabelecimentos idôneos para a promoção da readaptação social (BUSTOS RAMíREZ, 2005, pp. 153 a 157). 
imputação baseada na liberdade de vontade é meramente moral, ao passo que o direito penal deve buscar a reprovação social. Assim, pela reprovação social, resulta que o livre querer importa pouco, na medida em que a ameaça de pena deve buscar a não delinquência (uma vez que o ser humano é determinável por motivos fortes) e que a punição deve existir mesmo quando não logra evitar a prática criminosa (nas hipóteses em que o indivíduo encontrou em si motivações maiores do que aquelas derivadas do comando normativo), por conta da necessidade de manutenção da ordem jurídica. A proposta de FERRI, desse modo, representa um marco para a Escola Positiva, que assume como cerne a negação do livrearbítrio, coerente com um direito penal cuja principal função é a segurança social: na medida em que a pena busca corrigir o quanto possível o indivíduo e afastá-lo do convívio em sociedade, a ideia da liberdade de vontade pode ser suprimida (RoDRíGUEZ, 2014, pp. 173 a 176).

No Brasil, em defesa da inexistência do livre-arbítrio, destaca-se o estudo "O determinismo psychico e a imputabilidade e a responsabilidade criminaes - Memoria apresentada ao Congresso Scientífico latino-americano", de Pedro LESSA, publicado em 1905. Nesse ensaio, o professor de São Paulo busca analisar a compatibilidade das noções de imputabilidade e de responsabilidade criminais com as duas teorias que, à época, "alimentavam a pretensão de explicar o mecanismo da vontade humana": o determinismo e o livre-arbítrio. Para tanto, inicia seu trabalho apresentando os fundamentos de cada tese. A respeito dessa, define-a como o poder da vontade humana de se autodeterminar, de decidir entre duas possibilidades opostas, em virtude da própria iniciativa do sujeito, superior a qualquer influência estranha - interna ou externa. Acerca daquela, identifica três doutrinas diversas conhecidas pelo nome de determinismo: o determinismo mecânico, o determinismo fisiológico e o determinismo psíquico. A primeira, fundada na premissa de que a energia no seio do universo é sempre a mesma e que, portanto, toda força se resolve em movimento e todo movimento em força, pretende daí deduzir a explicação do mecanismo da vontade humana. A segunda, por sua vez, busca explicar todos os atos voluntários do ser humano pelos instintos, pelas inclinações, pelos sentimentos, pelas paixões, pelo temperamento, pelo ambiente e pela "formação da sensibilidade", de maneira que são abstraídos os "motivos superiores", as ideias e os preceitos da ética, fatores cuja intervenção na volição do indivíduo, na concepção do autor, a observação não permite negar. E a terceira, de seu turno, reconhece ao lado dos instintos, das inclinações, dos 
sentimentos, das paixões, das influencias do meio e do temperamento, mais outros fatores da volição: a ideia, o pensamento, o raciocínio, os conhecimentos científicos etc. (LESSA, 1905, pp. 3 a 7$)$.

Adepto da doutrina do determinismo psíquico, LESSA entende ser ela a única teoria compatível com a imputabilidade e com a responsabilidade criminais. Compreendendo a imputabilidade criminal como a possibilidade de atribuição da prática de um delito a um determinado sujeito - no sentido de esse ser a causa daquele -, argumenta o autor que a teoria determinista explica a imputabilidade a partir do seguinte raciocínio: a volição é uma resultante das ideias e dos sentimentos; as ideais e os sentimentos de cada individuo são resultantes da educação, da instrução, do ambiente físico, individual e social, das influencias hereditárias, enfim, de todos os fatores particulares que concorreram para a formação do ethos peculiar ao indivíduo; consequentemente, por lógica, pode-se vincular o ato praticado por uma pessoa, como efeito, a essa pessoa, como causa. Ter-se-ia, assim, um consequente, que se seguirá ao antecedente, ou ao conjunto de antecedentes, invariável e incondicionalmente, de maneira que repetindo-se a mesma constituição psíquica e os mesmos motivos, repetir-se-ia invariavelmente a mesma volição por um numero indefinido de vezes (LESSA, 1905, pp. 79 e 80).

Com relação à responsabilidade criminal, é referenciada, para LESSA, às finalidades da pena, no sentido de que se declara alguém responsável por um ato criminoso para que lhe seja imposta a pena cominada, impondo-se a pena para se alcançarem os seguintes fins: (i) intimidar e servir de exemplo, atuando no espírito dos demais indivíduos para que não pratiquem delitos; (ii) corrigir o delinquente, quando possível; e (iii) impossibilitar-lhe, temporária ou perpetuamente, a prática de novos crimes. Nesse sentido, as finalidades da pena apenas seriam compreensíveis desde a perspectiva do determinismo. Primeiramente, no que se refere à intimidação, por considerar o autor que a existência das normas jurídicas com as suas sanções seria inexplicável se o homem fosse dotado do livre-arbítrio, e não se determinasse pelos motivos mais poderosos, dentre eles a ameaça da pena. Em segundo lugar, no que tange à correção do delinquente, por entender que a recordação da pena imposta e cumprida será um motivo capaz de vencer no criminoso as tentações a ulteriores delitos, integrando em seu espírito uma causa superveniente de conduta. E, por fim, no que diz respeito à inocuização do delinquente, é consequência lógica do determinismo, uma vez que, crendo na relação existente entre certas constituições psíquicas e determinados atos socialmente danosos, do que decorre a "temibilidade" de dados indivíduos, a 
sociedade, para se defender de tais sujeitos perigosos, coata-lhes a liberdade. Em outras palavras, averiguada a relação entre a causa (indivíduo perigoso) e o efeito (comportamento delituoso), evita-se o efeito tornando inerte a causa (LESSA, 1905, pp. 85 a 105).

Na análise de Víctor Gabriel RodRígueZ (2014, pp. 185 a 190), a proposta de LESSA - vale dizer, de que o determinismo é a única concepção válida para o direito penal, que tem na pena um instrumento de controle social - tem o mérito de apresentar uma visão determinista ponderada, em que a ação humana é considerada como presa à manifestação do caráter. Considera o penalista contemporâneo, por outro lado, que não há esse mesmo equilíbrio por parte do jusfílósofo ao tratar das teses indeterministas, tendo em vista que a leitura desse autor é a de que, consoante o indeterminismo, a vontade não pode ser conduzida ou influenciada por qualquer fator (quer pela educação, quer por circunstâncias momentâneas, como a força coativa da pena) - razão pela qual julga tal visão como uma "esdrúxula concepção" (LESSA, 1905, pp. 77 e 78). Para RoDRíGUEZ, argumentar pelo absoluto acaba por ser uma das falhas da obra de LESSA, mas não desmerece inteiramente o texto, o qual acaba por constituir uma ampla síntese das ideias acerca das funções da pena e, além disso, por apresentar, de forma precursora no Brasil, a concepção da culpabilidade pelo caráter, a qual viria a ser uma das mais convincentes formulações de viés determinista.

3.5.1.2. Afastamento do debate acerca do livre-arbítrio $e$ a responsabilização penal fundada na prevenção por meio da pena: Enrique GIMBERNAT ORDEIG

A conclusão pela negação da culpabilidade é alcançada também outro por setor da ciência penal: o que não toma partido na polêmica filosófica entre determinismo e indeterminismo. Para essa ala da doutrina, embora não se saiba se o homem tem livrearbítrio ou não, fato é que a liberdade de decisão do sujeito no momento do cometimento de um crime (o "poder agir de outro modo") é inverificável e indemonstrável cientificamente, motivo pelo qual não pode ser considerada pressuposto ou requisito para a atribuição de responsabilidade penal. A consequência desse pensamento é que a pena deixa de ser encarada como castigo, como reação estatal a um injusto culpável, substituindo-se esse modelo por um Direito de medidas preventivas (direito penal sem culpabilidade e sem 
pena), ou por um sistema que mantenha formalmente as penas, mas não com conotação de retribuição justa ao autor de um fato culpável - e sim concebida materialmente com a mesma função preventiva, sobretudo preventiva-especial, das medidas de segurança (direito penal sem culpabilidade e com "penas-medidas") (LUZÓN PEÑA, 2012, p. 8).

Nessa linha, Enrique GimBERNAT ORDEIG (1990, pp. 142 a 158) propõe um modelo em que a sanção penal é fundamentada e dosada sem recorrer-se ao conceito de culpabilidade, mas considerando o critério da necessidade de pena. No esboço teórico do autor, em que a pena não está baseada na autodeterminação do agente - e, portanto, não tem o fito de retribuir uma culpabilidade inexistente, ou ao menos indemonstrável no caso concreto -, a sociedade recorre à pena para reforçar as proibições cuja observância se revele absolutamente necessária, buscando evitar, na maior medida possível, ações que ataquem os alicerces da convivência social, com a finalidade de conferir a tais vedações legais - com a ameaça da sanção penal, e sua execução em caso de transgressão à norma um especial vigor, que eleve à instância da consciência de cada indivíduo seu efeito inibidor (de ações dessa natureza). Na concepção do penalista espanhol, em um direito penal concebido com esses fundamentos, a pena não é mais algo irracional, mas racional e, mais do que isso, razoável, pois constitui um recurso elementar a que o Estado tem que recorrer para tornar possível a convivência social (GIMBERNAT ORDEIG, 1990, pp. 148 e 149).

Além disso, sustenta também o professor de Madri que o fato de a pena não estar fundada na retribuição e na expiação não significa que o Estado possa exercer o ius puniendi de maneira arbitrária, mas justamente o contrário, na medida em que, por se tratar a aplicação do aparato punitivo estatal de uma das mais graves intervenções na vida do cidadão, esse deve exigir do Estado o mais apurado, delicado e cuidadoso manejo da "força destrutiva" da pena, de maneira que o poder de punir está justificado somente enquanto exercido de maneira correta. Na mesma linha, o doutrinador defende que, mesmo sem a culpabilidade, é possível conceber um direito penal liberal e fundado na dignidade humana, uma vez que essa não estaria necessariamente atrelada àquele conceito (GIMBERNAT ORDEIG, 1990, pp. 151 e 152).

Contrariamente a esse argumento, Juan Bustos RAMíREZ e Hernán HERMOZABAL MALARÉE (1999, p. 320) afirmam ser difícil aceitar que o conceito de necessidade de pena, proposto por GIMBERNAT ORDEIG em substituição à culpabilidade, possa cumprir a função de uma responsabilização pessoal calcada na noção de dignidade humana. Consideram os 
autores que o critério da necessidade de pena é uma concepção vazia, cujo sentido deve ser buscado nas teorias da finalidade da pena, as quais, por sua vez, referem-se a parâmetros como as categorias do bem jurídico, a prevenção geral e a prevenção especial. O problema, para os doutrinadores, reside em que tais parâmetros, por um lado, não servem para explicar todos os fenômenos analisados no âmbito da culpabilidade - como, por exemplo, a inimputabilidade, a semi-imputabilidade, o erro de proibição, o estado de necessidade exculpante - e, por outro, não cumprem a função precípua da culpabilidade, vale dizer, de funcionar como garantia do cidadão frente ao poder punitivo do Estado.

$\mathrm{Na}$ doutrina mais moderna, desenvolvida ao longo do século XX, tem surgido posições de diversos matizes a respeito do problema aqui colocado: algumas delas negam a liberdade de vontade humana desde uma perspectiva determinista, enquanto outras afirmam que a liberdade do sujeito no momento da prática da infração penal é cientificamente indemonstrável. Os autores partidários desse entendimento, por sua vez, subdividem-se ainda entre os que rechaçam a culpabilidade e estruturam um conceito de delito sem tal elemento e aqueles que mantém essa etapa de atribuição de responsabilidade penal substituindo o termo culpabilidade por outros ou, diversamente, propugnando uma noção de culpabilidade baseada em dados empíricos - geralmente preventivos, como a normalidade e a necessidade de prevenção - e alheia absolutamente à ideia de reprovação normativa (apesar de aqui mencionadas, essas posições não podem ser classificadas como negacionistas ou negadoras da culpabilidade). Como consequência de tais compreensões, há, de um lado, a corrente que defende a eliminação da pena e sua substituição por medidas de segurança - de finalidade puramente preventivo-especial -, e, de outro, os partidários de um conceito de "pena sem culpabilidade" ou de um modelo de pena puramente preventiva, sem nenhum caráter de reprovação, justiça ou retribuição.

3.5.2. Responsabilização penal com culpabilidade: propostas de um novo substrato material determinado a partir de critérios extrínsecos

3.5.2.1. Culpabilidade como um déficit de fidelidade ao ordenamento jurídico em Günther JAKOBS 
Das tentativas destinadas a formular um modelo de responsabilização penal subjetiva que não elimina a culpabilidade, mas fundamenta-a desde as finalidades da pena, destaca-se a concepção de Günther JAKOBS. Coerente com sua orientação funcionalista ${ }^{34}$ de que a finalidade da pena é proteção da estabilização de expectativas normativas, o autor estrutura uma concepção de culpabilidade a partir dessa perspectiva.

Nessa linha, o conteúdo material da culpabilidade, para o professor de Bonn, corresponde à própria finalidade da pena, que em sua teoria é a prevenção geral - a qual, por sua vez, é expressão da própria função do direito penal, vale dizer, a proteção da validade das normas. A prevenção geral é concebida, por JAKOBS (1997, pp. 566 a 568), não como intimidação, mas enquanto exercício de fidelidade ao direito, de maneira que a culpabilidade é definida como a responsabilidade por um déficit de motivação jurídica dominante, em um comportamento antijurídico que afeta a confiança geral na norma. Em suma, a culpabilidade designa, para o doutrinador, a motivação contrária ao dever de fidelidade ao direito.

No modelo jakobsiano, para que se perfaça a culpabilidade, quatro são os requisitos cumulativos: (i) o autor deve comportar-se antijuridicamente; (ii) deve ser imputável, vale dizer, um sujeito com capacidade de questionar a validade da norma ${ }^{35}$; (iii) deve atuar não respeitando o fundamento de validade das normas; e (iv) conforme a espécie de crime, devem concorrer elementos especiais da culpabilidade inerentes àquela. Assim, a culpabilidade constitui-se na realização do tipo de culpabilidade - com o preenchimento dos elementos mencionados - em um contexto não exculpante. Contrariamente, não há culpabilidade com a configuração de um tipo de exculpação, caracterizado nas hipóteses de o autor do fato não poder ser considerado igual (inimputabilidade) ou de se encontrar em

\footnotetext{
34 Não há propriamente um funcionalismo, mas vários. Apesar das inúmeras diferenças teóricas que os afastam, têm as diversas concepções funcionalistas em comum a ideia de que o sistema jurídico-penal não deve vincular-se a dados ontológicos (ação, causalidade, estruturas lógico-objetivas, entre outros), mas sim orientar-se exclusivamente pelos fins do direito penal. Esses, para a doutrina, são variados, destacando-se as concepções de RoXIN, para quem a missão constitucional do direito penal é a proteção de bens jurídicos por meio da prevenção geral ou especial, e de JAKOBS, que entende ser a função do direito penal a proteção da validade das normas. À parte as divergências, no sistema funcionalista a teoria das finalidades da pena adquire valor basilar: se o delito é o conjunto de pressupostos da pena, devem ser esses construídos tendo em vista os fins e as consequências dessa (GRECO, 2000, pp. 320 a 322).

${ }^{35} \mathrm{Na}$ formulação de JAKOBS (1997, p. 598), imputável é uma pessoa definível como um igual. Essa igualdade pressupõe que os fatores que formam, ou não impedem, o processo motivatório no autor, em seus traços essenciais, também formam, ou não impedem, concomitantemente, um suceder motivatório. Com relação a esses fatores básicos relevantes para a motivação, importa unicamente seu gênero, não seu conteúdo ou intensidade, uma vez que esses são distintos de individuo para indivíduo. Isso posto, dada uma situação motivatória igual, em termos de gênero, em seus traços essenciais, a infração à norma por um sujeito exemplifica a infração à norma de qualquer autor equiparável, e por isso constitui um ataque à validade da norma em relação a qualquer um.
} 
uma situação especial da qual decorra o afastamento do dever de obediência à norma (inexigibilidade). $\mathrm{Na}$ ausência de igualdade, de que é consequência a inimputabilidade, há um defeito no processo de motivação do autor, que pode se verificar em dois casos: na falta de desenvolvimento de uma consciência social do sujeito - que é presumida nas crianças, mas deve ser analisada concretamente nos adolescentes e nos portadores de oligofrenia grave -; e na falta de competência do indivíduo, isto é, na perda de sua subjetividade, a ser demonstrada psico-fenomenologicamente, podendo fundar-se em condições orgânico-cerebrais. Na inexigibilidade de comportamento conforme o Direito, por sua vez, o processo motivatório do sujeito é normal, mas a culpabilidade é diminuída ou excluída quando a motivação não jurídica puder ser explicada por uma situação que, para o autor do fato, constitua uma "desgraça", ou que possa se imputar a outra pessoa. Em linhas gerais, não se configurará a culpabilidade quando concorrer alguma circunstância exculpante, caracterizada sempre que não se puder exigir do sujeito que obedeça à norma, na hipótese de, a despeito de presentes os requisitos da culpabilidade, a falta de motivação jurídica dominante puder ser considerada, deixando de lado o autor (JAKOBS, 1997, pp. 567 e 598 a 602).

Na esteira de seu pensamento, JAKOBS (1997, p. 584) sustenta que o que é a culpabilidade, concretamente, depende da estrutura de cada sociedade, sendo possível, em termos gerais, somente assinalá-la esquematicamente, pois as especificidades, como as causas de exculpação, apenas são possíveis de serem tratadas se referidas a um sistema social estabelecido com certa exatidão. $\mathrm{Na}$ construção do autor, o fundamento da culpabilidade está vinculado ao conceito de pessoa - atrelado aos papéis ou róis sociais desempenhados -, e dependerá de como se encontram normativamente estabelecidos os vínculos entre indivíduo e sociedade. O que, genericamente, se pode afirmar, é que, independentemente do sistema social a que se refira, o conteúdo da culpabilidade só poderá ser definido na medida da determinação da finalidade da pena. $O$ conceito de culpabilidade, para o autor, há de configurar-se funcionalmente, isto é, como conceito que produz um resultado de regulação - conforme determinados princípios de regulação (consonantes com os requisitos da finalidade da pena) -, para uma sociedade de estrutura determinada; e, segundo a concepção desenvolvida pelo doutrinador, o fim da sanção penal é do tipo preventivo-geral, relativo à manutenção do reconhecimento geral da norma - e não à intimidação. Nota-se, dessa formulação, que o conceito da culpabilidade não está 
atrelado a características naturais da ação - como conhecimentos e motivações -, mas à relevância comunicativa que uma determinada sociedade lhe outorga.

Em um sistema jurídico-penal em que a responsabilidade pessoal é fundada na manutenção da ordem social, em vez da reprovabilidade do sujeito por sua conduta, a discussão acerca do livre-arbítrio se torna irrelevante, segundo JAKOBS (1997, pp. 584 a 586; 2012, pp. 210 a 214; 1992, pp. 1081 a 1083). Na concepção do autor, sendo a culpabilidade a atribuição de responsabilidade em razão da lesão da vigência da norma, não faz sentido introduzir o questionamento acerca da liberdade de vontade, pois o único pressuposto desse elemento do delito é que o sujeito possa ser, desde parâmetros cognitivos, motivado pela norma, e nada além disso. Com efeito, defende o doutrinador ser certo que a culpabilidade está relacionada com a liberdade, mas não com a liberdade de vontade, com o livre-arbítrio, e sim, tão somente, com o que denomina de liberdade de autoadministração própria, ligada à possibilidade de o sujeito agir sem a presença de obstáculos juridicamente relevantes para seus atos de organização.

Conforme essa orientação, em que a culpabilidade não é o mesmo que reprovabilidade, mas que significa a ausência de fidelidade ao ordenamento jurídico - cuja consequência é a pena, concebida com a finalidade de reforçar a validade da norma, assegurando a manutenção da ordem social -, não importa se a vontade do sujeito que praticou o injusto era livre, mas apenas se ela foi formada em condições de normalidade cognitiva. Somente nas hipóteses de erro caracterizado em razão de defeitos $\operatorname{cognitivos}^{36}$, a culpabilidade pode ser excluída ou diminuída (JAKOBS, 1997, pp. 584 a 586; 1992, pp. 1058 a 1069).

Acerca da formulação jakobsiana da culpabilidade, Bernd SCHÜNEMANN (1991 [2], pp. 160 a 162) sustenta que tal proposta, que considera extrema, além de ser

\footnotetext{
36 JAKOBS (1992, pp. 1053 a 1055) define o que são os defeitos cognitivos diferenciando-os dos defeitos volitivos. Para chegar a essa especificação, parte da ideia de que as condições psíquicas que devem estar cumpridas para que uma norma seja respeitada, são, de um lado, a motivação para obedecê-la e, de outro, a capacidade mental de reconhecê-la e acatá-la, constituindo-se o comportamento, pois, de uma prestação volitiva (querer) e de uma prestação cognitiva (conhecer e compreender), respectivamente. Enquanto a ocorrência de um defeito volitivo, via de regra, agrava a responsabilidade, essa é exonerada - ou minorada na hipótese de um defeito cognitivo. Assim, explica o autor que quanto menor for a vontade do sujeito de respeitar a norma - ou, do ponto de vista inverso, quanto maior e mais obstinada for a infidelidade à norma da atitude do sujeito, mais grave será sua culpabilidade, a qual será menor, contrariamente, se tal déficit de fidelidade ao direito aparecer com um passo em falso eventual, atípico. Com relação aos aspectos cognitivos do agente, esclarece que quanto maior for a distância que o separar dos conhecimentos necessários definidos normativamente -, menor será sua culpabilidade, ao passo que essa terá intensidade superior na medida do quanto maior for a possibilidade de superar o desconhecimento.
} 
dogmaticamente incorreta, representa um risco ao direito penal atual, de cariz liberal, presidido pelos princípios do Estado de Direito. Para o autor, a substituição do conceito de culpabilidade pelas exigências da prevenção geral destruiria a estrutura valorativa contida na ideia de culpabilidade, a qual é essencial para o direito penal de um Estado de Direito, uma vez que as considerações preventivo-gerais, apesar de poderem fundamentar a utilidade funcional da pena, não são defensáveis em termos axiológicos ${ }^{37}$. Nessa linha, defende que em um Estado que não se funda no princípio de que "os fins justificam os meios" - mas, em conformidade com sua Constituição, no respeito à dignidade humana como sua finalidade precípua -, a imposição de uma sanção penal, enquanto instrumento de força mais enérgico e incisivo de atuação estatal, necessita de uma legitimação especial, além da comprovação de sua utilidade funcional. Assim, na concepção do professor de Munique, a pena criminal deve legitimar-se de modo que sua imposição a um cidadão concreto - que muitas vezes tem aniquilada sua existência social - apareça como uma medida justa e defensável também perante a ele, individualmente considerado, e não apenas em face da sociedade.

A legitimação da pena perante o apenado, para SCHÜNEMANN, deve estar presente ainda que houvesse perfeito conhecimento dos mecanismos de eficácia da prevenção geral e da prevenção especial, de maneira que só fossem impostas as penas absolutamente necessárias sob ambas perspectivas. Todavia, a realidade atual é que a invocação da ideia da prevenção especial não faz mais do que ocultar o efeito preponderantemente criminógeno das penas privativas de liberdade. Ademais, observa o autor que segue sendo uma questão pendente de resolução, até hoje, a relativa às condições sob as quais opera o direito penal de modo preventivo-geral, ou ainda até que ponto se pode diminuir a sanção aplicada e renunciar-se à pena antes de se anular a necessária eficácia preventivo-geral do direito penal. Diante desse contexto, assinala que não há dúvidas de que a pena necessita, para sua justificação, além da utilidade preventiva - que, ressalte-se, não está esclarecida e delimitada de modo definitivo -, de um princípio autônomo de legitimação: a culpabilidade. Isso porque, sob a vigência desse princípio, cabe argumentar a qualquer indivíduo que ele, ao atuar, sabia ou podia saber o que lhe esperava e que, em consequência, só receberá o que poderia prever e evitar. Com base nesse raciocínio,

\footnotetext{
${ }^{37}$ Segundo SCHÜNEMANN (1991 [2], p. 160), a razão pela qual uma argumentação funcional precisa sempre de um complemento axiológico parte do fato de que com a determinação da utilidade de uma dada medida aqui, expressamente, a pena criminal - para a obtenção de um dado fim, necessita-se avaliar, valorativamente, se esse fim é mais importante do que outros fins concorrentes - concretamente, se os bens jurídicos do autor atingidos pela pena são menos valiosos que o efeito preventivo que se pretende alcançar com a sanção penal.
} 
contrapondo-se ao pensamento de JAKOBS, SCHÜNEMANN conclui que somente o princípio da culpabilidade autoriza o Estado a tornar um indivíduo responsável por seus delitos e a impor-lhe sanções que atingem diretamente o núcleo de sua personalidade.

De uma perspectiva distinta, Hans Joachim HiRSCH (2007, pp. 30 e 31) também tece críticas à formulação de JAKOBS. Na compreensão daquele autor, a culpabilidade não pode ser concebida a partir da prevenção geral, por se tratarem de conceitos contrapostos por natureza. Primeiramente, porque representaria uma desindividualização da culpabilidade fundamentá-la na prevenção geral, considerando que é inerente àquela funcionar como a barreira que demarca o limite da responsabilização individual frente aos excessos dessa. E em segundo lugar, porquanto, ao contrário da culpabilidade, a prevenção não está dirigida ao passado - isto é, ao injusto praticado -, mas ao futuro.

Além disso, argumenta o professor de Colônia que a culpabilidade de JAKOBS é contraditória: tratando-se realmente de prevenção geral, tem-se que, desde a perspectiva da prevenção negativa, o efeito buscado por essa finalidade da pena seria maior se o requisito da culpabilidade - necessariamente limitador - não existisse em absoluto. E do ponto de vista da prevenção geral positiva, a teoria também não se sustentaria: se o que se pretende é a estabilização das expectativas normativas por meio da confiança geral na punição justa, aquela finalidade da pena não pode ser tomada como um pressuposto da sanção penal adequada e proporcional, mas, na melhor das hipóteses, como uma consequência dessa.

Na compreensão de HIRSCH, a inconsistência teórica da culpabilidade jakobsiana é de tal proeminência que sua concepção a partir da prevenção geral constituiria a maior confusão já experimentada no âmbito da teoria da responsabilização penal subjetiva. E, aderindo à crítica de Harro OTTO, assinala que quando se crê que a autoconcepção que o ser humano tem do livre-arbítrio, na qual se baseia o conceito de culpabilidade, pertence ao passado e que, em seu lugar, há de recorrer-se à ideia de prevenção, isso seria o mesmo que constatar que o respeito à dignidade humana também já não é atual.

\subsubsection{Culpabilidade como um déficit de fidelidade ao ordenamento jurídico em UrS KINDHÄUSER}

A substituição da "realidade" pela "comunicação sobre a realidade" como substrato ontológico do sistema jurídico-penal constitui, assim como em JAKOBS, a ideia central da 
formulação do conceito de culpabilidade material por KINDHÄUSER ${ }^{38}$, consistente em um déficit de lealdade comunicativa.

Para o autor, o Direito se concebe como um produto da autonomia comunicativa dos cidadãos em uma democracia, e sua infração como a lesão da autonomia dos demais cidadãos. Nesse modelo, a culpabilidade material aparece como a falta de lealdade com a autonomia comunicativa dos interlocutores da interação. Assim como JAKOBS, KINDHÄUSER entende que a culpabilidade do autor não se afere a partir de seu ato real - isto é, não se analisa sua conduta em si -, mas do ato comunicativo de negação da norma proibitiva que se supõe em um determinado fato real - como, por exemplo, em um homicídio. No mesmo sentido, no que diz respeito à pena - e a sua condição de afetação mais séria dos bens jurídicos do autor -, funciona, para ambos, como ato comunicativo de expressão da decepção ocasionada pela infração da norma (SCHÜNEMANN, 2000, pp. 100 a 102).

Conquanto aproximada em determinados níveis, as concepções dos professores de Bonn não são equivalentes, distanciando-se em outros aspectos. Nessa linha, KINDHÄUSER (2011 [2], pp. 77 a 79), em análise crítica da proposta de JAKOBS, entende que a interpretação da culpabilidade jurídico-penal por parte desse autor, orientada à prevenção geral, implica na renúncia a uma determinação material do sujeito de imputação. Isso porque, na construção desse doutrinador, o único pressuposto para se considerar culpável um agente seria de natureza formal, isto é, que se tratasse, do ponto de vista normativo, de um cidadão livre - o que significa ter direito a administrar sua própria mente e estruturar sua própria vida e, em contrapartida, comportar-se com fidelidade ao direito. Na leitura de KINDHÄUSER, para que essa interpretação do sujeito de imputação não seja puramente formal, JAKOBS pretende que as normas a serem obedecidas estejam legitimadas, vale dizer, que façam parte de um ordenamento jurídico que ofereça os recursos necessários para o livre e igual desenvolvimento de todos. Todavia, na compreensão daquele autor, a fidelidade ao direito não pode ser concebida como uma contraprestação à assistência do Estado, nem o juízo de culpabilidade pode limitar-se a falta de uma conformidade externa

\footnotetext{
${ }^{38}$ KINDHÄUSER (2011 [2], pp. 68 e 69) estrutura a culpabilidade em duas dimensões: uma formal e outra material. A perspectiva formal compreende o conteúdo de reprovação da culpabilidade formulado como resultado da imputação de um fato punível; verificar-se-á na ausência, por parte do autor, da formação de uma motivação a respeito da norma que tivesse prevalecido sobre a motivação que o impeliu a violá-la. Na concepção do autor, esse aspecto revela-se insuficiente para justificar o juízo de culpabilidade, por permanecer sem resposta as questões de por que se pune a ausência de motivação para o cumprimento da norma e de por que o autor deveria ter-se motivado para atuar conforme o Direito. É desde o panorama material, então, que se busca estabelecer um fundamento de legitimação da reprovação da culpabilidade, o que KINDHÄUSER faz, como se apresentará adiante, a partir da teoria comunitarista.
} 
com normas legítimas. Divergindo de JAKOBS, entende que a fidelidade ao direito deve fundamentar-se na autonomia participativa da compreensão comunicativa das normas, de maneira que a culpabilidade material esteja fundada em uma vinculação interna entre a norma e seu destinatário.

A despeito de partilhar com JAKOBS a compreensão da culpabilidade como infidelidade ao Direito, KINDHÄUSER (2011 [2], pp. 79 a 83) afasta-se daquele autor em pontos fulcrais de sua construção teórica. Formula, assim, uma concepção própria, que denomina teoria comunitarista da culpabilidade ${ }^{39}$, na qual o indivíduo não é tratado como pessoa privada que também pode atuar como cidadã no exercício de seus direitos e deveres, mas sim como cidadão nato, isto é, como indivíduo responsável pelo bem público, que deve cumprir as normas que asseguram a estabilidade do Estado e da sociedade para não prejudicar a aspiração social àquele interesse comum.

Na concepção de KINDHÄUSER, a identidade do indivíduo se forma dentro - e a partir - da sociedade, de maneira a construir uma relação indissolúvel entre o sujeito e o meio social no qual está inserido, a qual denomina de laço comunitário. Nesse meio social, o sujeito é compreendido como cidadão, isto é, enquanto indivíduo que surge com direitos e obrigações, especialmente a corresponsabilidade pela obtenção de um bem-estar comunitário. O conjunto normativo, o arcabouço jurídico, representam a forma de estruturação da comunidade, na qual o Direito exerce uma função social de integração, por meio da qual se constitui, junto ao mundo natural, um mundo social, composto de ordenamentos institucionais que determinam quais interações da generalidade pertencem correspondentemente às relações sociais autorizadas. Essa integração social depende de que os participantes componham suas inter-relações a partir do ajuste de comportamentos delimitados normativamente, e lograr-se-á quando as ações dos cidadãos se limitarem à área do devido.

\footnotetext{
${ }^{39}$ A concepção comunitarista da culpabilidade parte do comunitarismo, uma teoria normativa da sociedade cuja ideia política fundamental consiste em que uma democracia é tão boa ou tão ruim na medida do grau de cumprimento, pelos cidadãos, dos deveres cívicos que os vinculam. A despeito de ter sua origem na análise crítica do liberalismo da filosofia política e jurídica anglo-americana, o comunitarismo não confere menor valor à liberdade individual do que aquela linha de pensamento, mas tão somente a concebe de maneira diferente. Assim, para essa corrente teórica, não se trata a liberdade de uma categoria rigidamente configurada, e sim de uma condição alcançada com a participação dos indivíduos nos assuntos públicos, e assegurada por meio de sua atuação comprometida com a sociedade. Em oposição ao liberalismo, o comunitarismo não compreende o indivíduo de modo atomístico e anistórico, mas como um ser pertencente a uma sociedade concreta em um época concreta. Assim, a identidade de tal sujeito não se revela como uma dimensão lógica ou temporalmente prévia à sociedade, mas está desde o princípio constituída socialmente; e o estabelecimento da identidade individual por meio do contexto social fundamenta uma relação sinérgica entre o sujeito e a sociedade em que está inserido, formando uma comunidade da qual derivam as correspondentes obrigações de privilegiar o bem comum (KINDHÄUSER, 2011 [2], pp. 80 e 81 ).
} 
Nessa linha, a fidelidade ao Direito aparece como sinônimo de virtude cidadã, no sentido de um compromisso eticamente fundamentado em uma sociedade constituída juridicamente, da qual o indivíduo faz parte, ao passo que a culpabilidade significa o desprezo da responsabilidade pelo bem comum. Considera-se que, com a infração da norma, o sujeito abandona a comunidade, negando a integração social realizável sem violência por meio da compreensão comunicativa leal. Em outras palavras, o sujeito compreendido como cidadão pré-inserido na sociedade tem um dever de fidelidade ao Direito, enquanto obrigação de preservação de seus próprios direitos como cidadão. A culpabilidade aparece, então, como consequência da infração da norma, como um abandono da comunidade, já que o comportamento desviado representa um caminho distinto daquele estabelecido, de maneira prévia, comunitariamente, trazendo consigo um potencial desintegrador da própria sociedade. $\mathrm{Na}$ culpabilidade comunitarista de KINDHÄUSER, ademais, ao Direito não cabe apenas prescrever os deveres normativos e deixar a critério dos indivíduos as motivações para obedecê-los; ao contrário, essa neutralidade da ordem jurídica é rechaçada, pretendendo-se o cumprimento das normas enquanto virtude cidadã.

Em KINDHÄUSER (2011 [2], pp. 84 a 89), a desintegração da sociedade pela infração à norma é potencial, e não absoluta, uma vez que o comportamento desviado pode ser produto de uma má compreensão ocasional da norma, de um déficit pessoal ou geral de compreensão, ou de uma situação especialmente acidentada ou casual que, por suas circunstâncias extraordinárias, não gera questionamentos a respeito do sentido da norma violada. São nessas situações que residem as hipóteses de exculpação. Do contrário, quando o sentido de violação da norma está expresso como pretensão do sujeito, a culpabilidade será caracterizada.

Com relação à legitimidade da limitação do espaço de liberdade individual pelas normas, o autor apresenta um raciocínio sustentado em três conceitos básicos: a autonomia comunicativa, a lealdade comunicativa e o espaço livre comunicativo ${ }^{40}$. Assim, parte-se da

\footnotetext{
${ }^{40}$ Os três conceitos apresentados por KINDHÄUSER (2011 [2], pp. 85 e 86) para justificar o espaço de limitação da liberdade individual estão amparados na teoria da ação comunicativa de Jürgen HABERMAS, na qual, sinteticamente, o agir comunicativo é compreendido como uma interação de no mínimo dois sujeitos, capazes de falar e agir, que estabelecem relações interpessoais com o objetivo de alcançar uma compreensão sobre a situação em que ocorre a interação e sobre os respectivos planos de ação, com vistas a coordenar suas ações pela via do entendimento (PINTO, 1995, p. 80). A reconstrução do conceito de culpabilidade intentada por KINDHÄUSER parte de que a integração social - que, na concepção do autor, é função do Direito - está fundada em um entendimento comunicativo discursivo. Assim, o comportamento do sujeito a ser analisado, em um contexto penalmente relevante, não é apenas o instrumental, voltado ao resultado, mas sim o discursivo, orientado ao consenso. Consenso esse que é identificado pelo penalista alemão como a
} 
ideia de que as normas são criadas pelas pessoas para coordenar suas condutas futuras, de modo que os cidadãos se apresentam como criadores e também como destinatários das normas. Dessa maneira, possuem autonomia comunicativa em face das normas criadas, no sentido de que têm a autonomia pública de participação na elaboração normativa e a autonomia privada de conduzirem-se conforme as diretrizes estabelecidas.

O consenso social ${ }^{41}$, por outro lado, depende também da lealdade comunicativa dos participantes da sociedade, consistente no reconhecimento, por cada um, da existência de interesses alheios, o que impõe, por vezes, que o sujeito ceda um espaço às necessidades e exigências de outras pessoas. No espaço de atuação criado pela autonomia e pelo dever de lealdade, há um intervalo livre comunicativo, em que o sujeito pode agir no exercício de seu interesse pessoal ou de um direito subjetivo. Assim, enquanto o sujeito conduz-se em seu espaço livre comunicativo, está legitimado a atuar, mas quando ultrapassa os limites demarcados pelo Direito, rompe com o dever de lealdade comunicativa, negando a autonomia comunicativa dos demais - independentemente de considerações sobra a justiça da norma. Dessa forma, portanto, é que o conceito de culpabilidade se formula com base em uma falta de lealdade ao Direito: o consenso social concreto e válido somente pode ser obtido por meio do marco estabelecido pela norma, de maneira que com a quebra da norma o autor nega o acordo que a fundamenta e, com isso, a autonomia comunicativa do participante que com ele vivencia a situação de conflito, derivando daí sua culpa.

Acerca da relação entre culpabilidade e liberdade de vontade, KINDHÄUSER (2011 [1], pp. 212 e 213), considerando se tratar o livre-arbítrio humano de questão altamente controvertida, tanto na filosofia, quanto na antropologia - além de decisivamente posta em dúvida pela moderna neurobiologia -, não afirma, nem rechaça, qualquer tese a respeito. Todavia, posiciona-se o autor sobre a questão ao ressaltar ser um erro que a culpabilidade jurídico-penal respalde-se na pressuposição de livre-arbítrio; ou, em outras palavras, na

coordenação dos espaços de liberdade individual pelo reconhecimento do outro como pessoa, capaz de rechaçar pretensões, resultando como válido e digno de imposição apenas o melhor argumento, sempre que houver igualdade na oportunidade de discurso.

${ }^{41}$ KINDHÄUSER (2011 [2], pp. 101 e 102) esclarece que o conceito de consenso social a que se refere em sua teoria necessita ser delimitado. Assim, preliminarmente, informa que três são as formas possíveis de consenso. O denominado consenso subjacente, que é o pressuposto do entendimento, se refere à forma comum de vida, às convenções e valorações comuns e, sobretudo, à linguagem comum. O consenso de argumentação, por sua vez, se caracteriza quando os intervenientes, além de alcançarem um resultado compartilhado, também concordam com as razões que conduziram a esse resultado. Para o modelo pretendido pelo autor, de coordenação jurídica da ação orientada ao entendimento, no entanto, o conceito de consenso social que se revela adequado é o consenso de resultado, no qual basta que os intervenientes aceitem o resultado, o entendimento atingido, sem necessidade de que compartilhem também as razões para tanto. Na concepção do professor de Bonn, um consenso de resultado é, precisamente, um compromisso. 
suposição de que o ser humano é provido de autodeterminação livre, responsável e ética, razão pela qual teria condição de decidir-se a favor do Direito, e contrariamente ao injusto. Em sua compreensão, a culpabilidade não deve sustentar-se em assunções metafísicas, mas sim referir-se a uma práxis social, alicerçando-se em pressuposições de natureza normativa. Dito de outro modo, a culpabilidade jurídico-penal, enquanto conceito jurídico, deve, para o doutrinador alemão, fundamentar-se juridicamente. Isso significa, em termos concretos, que no Estado Democrático de Direito as pessoas de direito, no exercício conjunto de seus róis de destinatários e de autores das normas, devem determinar os conceitos de culpabilidade e de capacidade de culpabilidade.

Nesse sentido, KINDHÄUSER (2011 [1], pp. 228 a 231) defende que a atribuição de responsabilidade penal não pode depender de uma comprovação positiva da capacidade do sujeito de comportar-se conforme o Direito. Em sua visão, deve-se, assim como ocorre nas questões da vida cotidiana, dar por suposta referida capacidade e afastá-la apenas sob condições especiais, determinadas normativamente - vale dizer, pelos cidadãos, por meio do processo democrático. Nesse modelo, os conceitos negativos de liberdade passam a desempenhar um papel determinante, de maneira que a liberdade, definida normativamente, passa a significar a ausência das condições reconhecidas de falta de liberdade.

Para o professor de Bonn, a legitimidade, na imputação de culpabilidade jurídicopenal, da suposição universal da capacidade de seguir a norma e de sua negação em determinadas condições excepcionais reside na consideração do ser humano enquanto pessoa de direito, especificamente em seu duplo rol como destinatário e como autor da norma, cujo fundamento é idêntico. A ideia central é que daquele a quem se outorga o direito de tomar posições críticas e racionais acerca de uma norma também se espera que possa avaliar crítica e racionalmente seu próprio comportamento. Em outros termos, tal como a suposição geral de capacidade de culpabilidade, o exercício do direito de expressar opiniões, de participar de sufrágios etc., não depende da comprovação positiva da presença de determinadas capacidades.

Assim, as causas de exculpação aparecem como regras de Direito estabelecidas por meio do processo legislativo, legítimas porque determinadas pelos membros de uma sociedade democrática e juridicamente constituída, que assumem a responsabilidade de definir como e em que medida eles querem estar vinculados às normas - especificamente, como a responsabilidade pela contravenção às normas deve ser atribuída a si próprios, 
enquanto cidadãos. De certa forma, afirma KINDHÄUSER (2011 [1], p. 231), os cidadãos se olham no espelho quando estabelecem os critérios sob os quais eles próprios ficarão vinculados ou exonerados em seu rol de destinatário das normas.

Por fim, o autor conclui que a origem e a legitimação do direito apenas podem ser encontradas na autonomia do indivíduo. No que atine ao direito penal, a consequência disso é que também a culpabilidade deve ser determinada em conformidade com a autonomia correspondente a cada cidadão, uma vez que quem pode pretender ter a capacidade de tomar posição racionalmente acerca das normas, também deve assumir-se como capaz de seguir essas mesmas normas. Segundo o doutrinador, disso resulta, em ultima análise, que o direito penal só é legítimo no marco de um Estado Democrático de Direito.

Em análise crítica da teoria de KINDHÄUSER, SCHÜNEMMAN (2000, pp. 101 e 102) argumenta que o que resta da pena, e de sua realidade como afetação mais séria dos bens jurídicos do autor, naquela formulação, é somente o ato comunicativo de expressão da decepção ocasionada pela infração da norma. Além disso, para o professor de Munique, a transformação da realidade em uma suposta comunicação, na teoria de KINDHÄUSER, parte de uma afirmação que não se sustenta, vale dizer, de que o Direito não pode demonstrar sua correção e, portanto, depende de um reconhecimento e uma justificação comunicativos. Isso porque essa dedução confundiria dois níveis completamente distintos, pois a vigência da norma jurídica demonstra, por si só, sua correção para o discurso dogmático - que é aquele que se ocupa do conceito de culpabilidade -, enquanto que o discurso democrático sobre uma eventual reforma da norma não se desenvolve na dogmática jurídica, mas no campo da política jurídica. Ademais, a substituição da consideração do acontecimento real como objeto de valoração por um suposto ato de comunicação que valora esse acontecimento, concebido como negação ou como confirmação da norma, acarreta uma mudança de nível do objeto do direito penal: do autêntico comportamento lesivo ao bem jurídico e do castigo real do autor, para um metanível.

3.5.3. Responsabilização penal com culpabilidade: propostas de uma determinação revisada da culpabilidade a partir de critérios intrínsecos

3.5.3.1. SCHÜNEMANN e a concepção indeterminista da culpabilidade em um Direito como realidade socialmente criada 
A formulação do conceito de culpabilidade em Bernd SCHÜNEMANN (2009, p. 470) parte de sua compreensão do direito penal atual, segundo a qual a responsabilização criminal depende decisivamente de fundamentação na liberdade de vontade humana, vale dizer, no indeterminismo. Na concepção do professor de Munique, o direito penal encontra o livre-arbítrio como uma parte previamente dada da realidade comunicativa, que de modo algum se pode ignorar. Reconhece, nesse âmbito, que a socialização, enquanto progressiva integração do indivíduo aos valores sociais, se efetua por meio da linguagem. Contudo, considera que a experiência subjetiva da liberdade do indivíduo é parte da realidade social, de maneira que qualquer análise de interação social em termos de reprovação ou de exculpação, em nossa sociedade, deve se basear, naturalmente, na ideia de livre autodeterminação.

O reconhecimento recíproco da liberdade de vontade, em nossa sociedade e cultura, estaria provado, à parte da experiência subjetiva de cada indivíduo, nas estruturas linguísticas: as formas gramaticais ativas ou passivas e a distribuição do caráter dos sujeitos como eu, tu e os terceiros que não participam diretamente da interação, seriam a expressão de uma visão de mundo criada por um sujeito que decide livremente. Conquanto admita que o Direito é um produto cultural e, portanto, uma porção da sociedade criada, apoiado nos pressupostos elementares da interação social, entende que os partidários do determinismo e os representantes do conceito social de culpabilidade estão em total contradição com uma prevenção geral intimidatória como fundamento do direito penal. Isso porque se, como esses doutrinadores afirmam, não é possível de ser comprovado que o individuo pode agir, na situação concreta, de outra maneira, perderia sentido o conceito de prevenção geral intimidatória, voltado a motivar o autor ao comportamento conforme ao Direito mediante a ameaça de pena. A razão disso, de acordo com SCHÜNEMANN, é que se o autor não tem nenhuma liberdade de decisão, duas são as situações possíveis: ou será forçosamente impedido de praticar o delito mediante a ameaça de sanção penal - e então não haveria fundamento algum para a aplicação da pena; ou os motivos para o cometimento do crime serão de tal maneira intensos que a ameaça penal já não provoca qualquer efeito. Diante dessa realidade, a ameaça de pena simplesmente perderia o sentido - assim como, em suas palavras, igualmente careceria de sentido proibir um furacão que devaste uma cidade -, de modo que o conceito de prevenção geral intimidatória só seria compreensível em um sistema indeterminista (SCHÜNEMANN, 2009, pp. 472 a 474). 
Na concepção de SCHÜNEMAnN (2009, pp. 474 a 481), o direito penal deve ter como premissa o "poder atuar de outro modo" de um ser humano médio em uma situação intermédia, o que, em termos de culpabilidade, respalda a noção de reprovabilidade do ato e a legitimação da sanção frente ao culpável. Para o autor, a reprovação supõe tão somente que o destinatário da norma poderia ter observado o dever de respeito àquela, e que não o fez. E negar a ideia de reprovação significaria refutar a ideia de liberdade que toda pessoa possui, razão pela qual o legislador não poderia formular um chamado de obediência à norma. Mais do que isso, repudiar a liberdade de vontade do ser humano meramente em função de sua indemonstrabilidade empírica teria por consequência necessária considerar que o direito penal não pode aplicar penas, mas somente medidas de segurança, projetando-se para a inocuização.

Contrariamente a esse quadro que considera deletério, SCHÜNEMANN (2000, pp. 112 e 113) sustenta a existência do livre-arbítrio, afirmando que a liberdade de um ser humano normal, para comportar-se em uma situação normal de uma maneira ou de outra - e, portanto, para comportar-se também conforme ao Direito -, assenta-se firmemente em nossa realidade (constituída linguisticamente e ineludível para qualquer função social vinculada à linguagem) não como mera ficção ou uma asserção normativa, mas como parte da realidade social.

\subsubsection{HASSEMER e a culpabilidade sem reprovação}

Winfried HASSEMER (1999, pp. 51 a 62), partindo da constatação de que o princípio da culpabilidade encontra-se ameaçado no direito penal atual - tanto na teoria, quanto na práxis - pelos interesses de uma política criminal eficaz, busca propor um modelo que conserve o que considera serem suas missões irrenunciáveis - possibilidade de imputação subjetiva, exclusão da responsabilidade pelo azar, diferenciação e valoração da participação interna no acontecimento externo e garantia da proporcionalidade das consequências jurídico-penais -, mas reformulado em outros aspectos. Constrói, assim, uma concepção de culpabilidade que renuncia à ideia de reprovação, a qual considera insustentável do ponto de vista teórico e prejudicial de uma perspectiva prática.

Para o professor de Frankfurt, ainda que não se possa conceber o direito penal e a vida cotidiana sem a ideia de liberdade de vontade, nem se possa compreender as relações humanas em geral desde um panorama determinista, revela-se um acerto a desvinculação, 
pela dogmática da culpabilidade, da polêmica acerca do livre-arbítrio. Isso porque, em sua compreensão, a ideia da liberdade como condição - ainda que transcendental - da possibilidade de comunicação humana não é apta a servir de base a uma reprovação penal frente ao delinquente. De acordo com o autor, as circunstâncias em que uma condenação pode fundamentar-se devem estar reunidas, como um todo, dentro do processo penal, submetido ao método da observação. Nesse contexto, a questão do livre-arbítrio restaria subtraída a priori, antes mesmo do início da observação, voltando-se o processo penal, por meio de seu instrumental, para a verificação de eventuais limitações materiais da liberdade de vontade, vale dizer, de indicadores de déficit de liberdade no caso concreto (HASSEMER, 1999, p. 58).

A problemática que envolve a liberdade de vontade, no entendimento de HASSEMER (1999, pp. 58 a 60) é totalmente irrelevante para o princípio da culpabilidade, pois inclusive uma posição indeterminista seria incapaz de oferecer substrato à noção de reprovabilidade. A reprovação penal, segundo o doutrinador, ao ensejar a responsabilização unicamente do agente pelo fato, despreza os múltiplos fatores criminógenos que concorrem com a prática delituosa e permite que a sociedade afetada pelo mal causado pelo delito o projete em direção ao sujeito que o disparou - que funciona como um bode expiatório -, expulsando-o do convívio social.

Conquanto defenda um conceito de culpabilidade sem reprovação, HASSEMER (1999, pp. 60 e 61) adverte que essa estrutura não representa uma supressão da função limitadora daquele princípio, uma vez que a ideia de reprovabilidade não teria qualquer traço de limitação, mas justamente o contrário, estendendo em grande medida a carga de sanção penal ao delinquente. Em verdade, os limites da pena, para o doutrinador alemão, se deduziriam mais adequadamente dos critérios de proporcionalidade do que do princípio da culpabilidade, sendo necessário apenas aperfeiçoar tais parâmetros, a partir de um trabalho teórico e empírico que envolvesse investigações sobre a gravidade do fato e a intensidade da sanção, assim como a respeito da sensibilidade e da receptividade à pena, por parte do condenado.

Ademais disso, observa o autor que embora não se faça necessária a demonstração, pelo juiz, da liberdade de ação do sujeito - o que seria impossível -, mostra-se acertada a previsão, na lei penal, de situações nas quais a exculpação está justificada - vale dizer, de graves anomalias, de erro, de inexigibilidade de comportamento conforme ao Direito. Isso porque o caráter histórico dessas hipóteses, enriquecidas de significado pelas discussões 
realizadas na teoria e na práxis, demonstraria que tais condições não são indícios negativos de liberdade de ação e de reprovação, mas sim limites de criminalização próprios de um direito penal humano. Assim, atento o juiz penal a esse programa, estaria assegurado que a ninguém viesse a ser imposta uma consequência jurídico-penal por haver cometido um fato pelo qual não é responsável.

\subsubsection{MUÑOZ CONDE e a concepção dialética da culpabilidade}

Tomando por referência a impossibilidade de demonstração do livre-arbítrio, Francisco MuÑOZ CONDE (2007, pp. 136 a 143) repudia a concepção normativa da culpabilidade e propõe a reconstrução do conceito, a partir de sua compreensão enquanto fenômeno social, e não como fenômeno meramente individual. Assim, assenta a necessidade de abandono completo da compreensão tradicional da culpabilidade - que seria produto da ideologia individualista dominante no momento em que surgiu como categoria autônoma do direito penal - e sua convolação em uma culpabilidade social, na qual a sociedade - e o Estado, enquanto seu legítimo representante - define os limites do culpável e do não culpável, da liberdade e da não liberdade. Nesse contexto, a culpabilidade não se apresentaria como qualidade da conduta, mas como uma característica que se lhe atribui para que se possa imputá-la a alguém como seu autor e fazer-lhe responsável por ela. Mais do que isso, a culpabilidade deixaria de ser encarada como uma categoria abstrata ou anistórica, à margem das finalidades preventivas do direito penal, passando a ser concebida como a culminação de todo um processo de elaboração conceitual destinado a explicar por que e para que, em determinado momento histórico, se recorre a um meio de defesa da sociedade tão grave como a pena, e em que medida esse instrumento deve ser utilizado. A defesa de determinados interesses por meio da pena expõe, para o autor espanhol, a intrínseca correlação entre culpabilidade e prevenção geral ${ }^{42}$, as quais, compreendidas em conjunto, constituem uma concepção dialética daquele conceito.

\footnotetext{
${ }^{42}$ MUÑOZ CONDE (2007, p. 139) explica a ligação entre culpabilidade e prevenção geral a partir do seguinte exemplo: se em um determinado momento histórico considerou-se que devia ser declarado isento de responsabilidade penal o menor de certa idade, o sujeito que, por conta de qualquer anomalia ou alteração psíquica não pode compreender a ilicitude do fato ou atuar conforme essa compreensão, e aquele que, por sofrer alterações em sua percepção desde o nascimento ou desde a infância, tem alterada a consciência da realidade, isso não foi feito para enfraquecer a prevenção geral ou a defesa dos interesses da sociedade frente a essas pessoas, mas justamente o contrário, uma vez que o efeito intimidatório geral e a defesa social se fortaleciam ao declarar-se isentos de responsabilidade criminal - isto é, de culpabilidade - algumas poucas pessoas das quais, como ensina a experiência, não pode esperar-se que cumpram as expectativas de conduta
} 
A compreensão da culpabilidade em conjunto com a prevenção geral, contudo, não resolve o problema central da concepção normativa da culpabilidade, vale dizer, a impossibilidade da demonstração de que o sujeito que pratica o injusto culpável poderia ter atuado de outro modo. Tendo isso em vista, propõe MuÑoz CondE (2007, pp. 140 a 144) que o fundamento material da culpabilidade esteja referido não mais à liberdade de vontade, ao poder agir de outro modo, mas à função motivadora da norma penal, voltada à proteção de bens jurídicos e dirigida aos indivíduos capazes de motivarem seus comportamentos conforme os mandados normativos. Nessa formulação, a questão central não é mais saber se o sujeito pode eleger uma dentre várias formas de conduta, mas observar se a norma penal, com seus mandados e proibições, o motiva para que se abstenha de realizar um desses vários comportamentos possíveis - expressamente, aquele que a norma proíbe mediante a ameaça de pena.

Nesse modelo, a motivabilidade - isto é, a capacidade de motivar-se pelas exigências normativas - é concebida como a faculdade humana fundamental que, unida a outras - como a inteligência, a afetividade, etc. -, permite a atribuição de uma ação a um sujeito e, consequentemente, a responsabilização pela conduta que foi praticada. Contrariamente, nas hipóteses em que se verifique alguma alteração importante dessa faculdade, independente de sua origem, a culpabilidade deverá ser excluída ou, ao menos, atenuada. Na construção teórica do professor de Sevilha, haverá capacidade de motivação pela norma quando o indivíduo alcançar um determinado desenvolvimento biológico, psíquico e cultural, pois a partir dessa conquista estará em igualdade de condições com seus semelhantes para participar de uma vida em comum, pacífica e organizada. Esse determinado grau de desenvolvimento deverá estar delimitado normativamente, e em consonância com as exigências da prevenção geral de uma sociedade em um dado momento histórico.

\subsubsection{ZAFFARONI e a culpabilidade por vulnerabilidade}

Eugenio Raúl ZAFFARONI (2006, pp. 507 a 520), partindo de pressupostos criminológicos e de sociologia criminal, formula um conceito de culpabilidade calcado na ideia de vulnerabilidade ao poder punitivo. O pressuposto dessa concepção é o de que o Estado não é de todo racional e persegue o cidadão com um afã de policiar e dominar

contidas na norma penal, confirmando assim a necessidade de seu cumprimento pelas demais pessoas que não se encontram nessa situação. 
sujeitos socialmente excluídos e, ao fazer sua seleção criminalizante, utiliza-se de preconceitos e estereótipos, voltando seu poder de punir àqueles que mais facilmente se põe a seu alcance, cometendo delitos de modo grosseiro. Nesse contexto, o ius puniendi estatal se revela mais perigoso para umas - em geral, os homens, os adolescentes, os desocupados, os imigrantes de países pobres etc. - do que para outras pessoas, tornando aquelas mais vulneráveis à punição.

Segundo o autor argentino, o direito penal, diante dessa realidade, deve funcionar como um limite à ânsia de punição do Estado, colocando freios ao poder estatal em face daqueles que estão colocados em situação de vulnerabilidade à sua ação. E, dentro do direito penal, tal tarefa deve ser desempenhada pela culpabilidade, cuja maior função está em estabelecer critérios e filtros à magnitude do poder punitivo que o Estado pode exercer sobre o cidadão. Disso decorre que a culpabilidade não funciona como um meio de racionalizar o ius puniendi estatal - que segue sendo irracional e perigoso -, mas como um instrumento de busca de racionalidade na reação punitiva, com a imposição de limites a essa. Assim, a graduação da pena pela culpabilidade deixa de pautar-se somente pelo conteúdo do injusto objetivamente considerado, passando a ponderar também a condição humana do agente, com suas idiossincrasias e sujeito a alterações de caráter.

Acerca de sua construção teórica, ZAFFARONI (2006, pp. 519 e 520) esclarece que a culpabilidade por vulnerabilidade não é uma alternativa à culpabilidade como reprovação formalmente ética, senão um passo superador dessa, que a conserva em sua síntese. Afirmada a culpabilidade formalmente ética como culpabilidade pura pelo fato - conforme o âmbito de autodeterminação com que o sujeito pode deliberar -, apresenta-se, em contrapartida, a culpabilidade pela vulnerabilidade, para contrabalançar a desconsideração, por parte daquela, da seletividade penal. Harmonizadas ambas as faces da responsabilização penal subjetiva, essa sintetiza-se em uma culpabilidade normativa penal que pode ter seu nível de reprovação diminuído, mas nunca ampliado, em relação àquele estabelecido em um primeiro momento. A culpabilidade resultante dessa síntese traduz o esforço - ético e legítimo - do saber jurídico-penal para reduzir, em máxima medida possível, o resultado da culpabilidade formalmente ética.

Argumenta o professor de Buenos Aires de que se trata, portanto, de um conceito de culpabilidade mais completo, consistente em um juízo que, de um lado, vincula de forma personalizada o injusto a seu autor; e, de outro, opera como principal indicador da máxima magnitude que o poder punitivo estatal pode ser exercido sobre o sujeito. Esse 
juízo resulta da síntese de uma reprovação fundada no âmbito de autodeterminação da pessoa no momento do fato - formulada com base em elementos formais proporcionados pela ética tradicional -, com uma reprovação pelo esforço do agente para alcançar a situação de vulnerabilidade em que o sistema penal concretizou sua periculosidade, descontando desse o mero estado de vulnerabilidade ${ }^{43}$.

Com relação ao âmbito de autodeterminação com que o sujeito atuou, fator considerado no juízo de reprovação do autor pelo fato praticado, ZAFFARONI (2006, pp. 507 a 509) explica que se rege pelo princípio de que a ninguém pode ser atribuído o cometimento de um injusto se esse não houver sido resultado de sua livre determinação. Segundo o autor, essa questão não está relacionada ao que denomina conceito idealista ou romântico de livre-arbítrio, no sentido de que todos os seres humanos são igualmente livres. Em sua compreensão, se esse fosse o caso, isto é, fossemos todos iguais e imutáveis, a culpabilidade seria prescindível, de maneira que é justamente por termos diferentes âmbitos de autodeterminação que se faz necessário delimitar com precisão qual foi o espaço de decisão que, de fato, teve a pessoa no momento da realização do ato, levando em consideração suas condições pessoais e as circunstâncias nas quais se encontrava concretamente.

Para o autor, todos os seres humanos contamos com certo espaço de decisão, que não é infinito nem idêntico em todas as circunstâncias. E contra aqueles que afirmam que essa constatação é - ou pode ser - uma ilusão, uma vez que a autodeterminação não seria verificável empiricamente e, por isso, seria impossível fundar cientificamente um juízo de reprovação personalizado, ZAFFARONI expõe alguns argumentos para corroborar seu ponto de vista. Primeiramente, que tampouco o determinismo seria demonstrável empiricamente. Em segundo lugar, que seria cientificamente verificável que na interação social os humanos nos comportamos como se tivéssemos âmbitos de autodeterminação e, com base nisso, fazemos cotidianamente toda sorte de avaliações negativas e positivas. Em terceiro, que a psicologia provaria que cada um de nós, segundo a nossa personalidade e as situações vivenciadas concretamente, temos um certo catálogo, ainda que limitado, de

\footnotetext{
${ }^{43}$ A ninguém pode ser reprovado, racionalmente, seu estado de vulnerabilidade, mas somente o esforço pessoal para alcançar a situação em que o poder punitivo se concretiza. Assim, em casos em que a vulnerabilidade do sujeito for baixa, esse deve realizar um esforço maior para que alcance a situação concreta de intervenção penal, hipótese em que a reprovação será maior. Contrariamente, e isso representa o grosso dos criminalizados, quando não se realizam grandes esforços para alcançar a situação concreta de vulnerabilidade, por se partir de um estado consideravelmente elevado, bastando muito pouco para que se concretize nesses sujeitos a perigosidade do poder punitivo, a reprovação por vulnerabilidade terá grau menor (ZAFFARONI, 2006, pp. 517 e 518).
} 
condutas possíveis. Além disso, seria também verificável que quem dispõe de experiência e de treinamento pode enfrentar algumas circunstâncias com mais opções de comportamento que outro. E, por fim, a possibilidade de eleger seria um atributo da noção de pessoa no sentido do direito internacional dos direitos humanos e do próprio direito constitucional.

A concepção de culpabilidade por vulnerabilidade, destarte, é toda edificada com base nesta premissa: a vontade e a atuação do sujeito não são determinadas, mas formadas dentro de um espaço limitado de liberdade.

3.5.4. Responsabilização penal com culpabilidade: a posição integradora de ROXIN

Com o intuito de contornar a indemonstrabilidade do livre-arbítrio e a vinculação da reprovabilidade a valores ético-sociais - pontos centrais na crise da culpabilidade finalista -, Claus RoxIN (1981, pp. 70 a 72) busca redefinir o conceito de culpabilidade em face das demais categorias do delito. Assim, na concepção do autor, enquanto a tipicidade estabelece, para todos os cidadãos, em nome da prevenção geral, os parâmetros legais de criminalização e a antijuridicidade descreve o comportamento correto em determinadas situações de conflito, a culpabilidade, por sua vez, está relacionada à pergunta de se do ponto de vista penal uma sanção contra um indivíduo concreto é ou não necessária, em vez do questionamento de se outro comportamento do autor era possível nas dadas circunstâncias.

Essa guinada de enfoque intentada pelo doutrinador representa um desenvolvimento da culpabilidade normativa até um conceito de responsabilidade, no qual aquela funciona como um dos componentes dessa, juntamente com elementos de política criminal relacionados à função da pena ${ }^{44}$. No modelo formulado pelo professor de Munique, o injusto - tipicidade e antijuridicidade - é voltado ao problema da adequação de determinado comportamento ao direito penal, enquanto que a responsabilidade é orientada à questão da necessidade de sanção penal em cada caso individual, desde parâmetros político-criminais.

\footnotetext{
${ }^{44}$ A proposta, por RoXIN, de reformulação do conceito de culpabilidade não é uma construção isolada em sua teoria, mas decorrente da concepção sistêmica do autor a respeito das ciências criminais, na qual a dogmática penal e a política criminal são compreensões convergentes do fenômeno criminal. De acordo com essa formulação, a dogmática deve deixar-se permear, definindo-se, pela missão do direito penal como instrumento de política criminal, isto é, pela prevenção delitiva (TANGERINO, 2011, p. 88).
} 
Em termos concretos, o aperfeiçoamento da responsabilidade depende da presença de dois fatores: a culpabilidade do sujeito e a necessidade preventiva da pena, que deve ser deduzida da lei. Na formulação roxiniana, a culpabilidade se perfaz com a realização do injusto, apesar da capacidade de reação normativa e da faculdade de conduzir-se, dela derivada. Em outras palavras, o sujeito atua culpavelmente quando realiza um injusto jurídico-penal, não obstante lhe fosse acessível, na situação concreta, o conteúdo da norma e tivesse capacidade suficiente de autocontrole para adotar uma alternativa de conduta conforme ao Direito. Segundo Roxin (1997, p. 792), um comportamento culpável, nesses termos, acarreta, normalmente, a necessidade de sanção penal por razões preventivas: quando o legislador plasma uma conduta em um tipo penal, parte da ideia de que deve ser combatida, em princípio, por meio da pena, sempre que verificadas a antijuridicidade e a culpabilidade. Dessa maneira, a necessidade preventiva de punição não precisa de uma fundamentação ou justificação especial, havendo responsabilidade jurídico-penal, em regra, com a mera caracterização da culpabilidade. Todavia, é possível que o legislador preveja, a partir de critérios político-criminais, certas situações excepcionais nas quais, ainda que verificada a culpabilidade, a pena não se revele preventivamente indispensável, devendo portanto ser renunciada.

Nessa construção teórica, a culpabilidade segue sendo o pressuposto decisivo apesar de não mais o único - da responsabilidade penal. Lapidada em seu conteúdo, tem reforçada, com o estreitamento de sua relação com a punibilidade, a finalidade de impor um limite ao poder punitivo do Estado - particularmente, às necessidades públicas de prevenção. RoXIN (1997, p. 798) ressalta, contudo, que o cumprimento adequado dessa função depende de como se defina o conteúdo de culpabilidade, na medida em que o conceito normativo, para o qual conduta culpável é sinônimo de conduta reprovável, para além de outros problemas, é de natureza completamente formal, não carregando consigo os pressupostos materiais dos quais depende.

Na compreensão de RoxIN (1997, pp. 807 a 812), a culpabilidade deve ser entendida, desde o ponto de vista substancial, como a atuação injusta apesar da existência de acessibilidade normativa. Em outros termos, isso significa que a culpabilidade se caracteriza quando: (i) um sujeito estava disponível, mental e animicamente, no momento do fato para a chamada da norma; (ii) lhe eram psiquicamente acessíveis possibilidades de decisão por uma conduta orientada conforme à norma; e (iii) existia no caso concreto a possibilidade psíquica de controle - seja ela livre ou determinada - que há no adulto são na 
maioria das situações. Para o professor de Munique, diferentemente da "possibilidade de outra conduta pelo autor na situação de cometimento do injusto", os parâmetros apresentados não se consubstanciam em hipótese indemonstrável, mas sim em fenômenos científicos empíricos, mensuráveis pela psicologia e pela psiquiatria, as quais disporiam de conhecimentos para constatar eventuais restrições à capacidade de autocontrole do sujeito, bem como medir sua intensidade.

A existência da acessibilidade normativa, tal qual proposta pelo penalista alemão, pressupõe a ideia de que o sujeito possui capacidade de comportar-se conforme a norma, convertendo-se em culpável ao não adotar nenhuma das alternativas de conduta que em princípio lhe eram psiquicamente alcançáveis. Essa tese, conquanto possa ser interpretada à luz do indeterminismo, não dependeria da existência de liberdade de vontade, sendo também compatível, na compreensão de Roxin, com o determinismo e com o agnosticismo dos que se declaram desconhecedores da existência ou não do livre-arbítrio. Isso porque, de acordo com essa concepção da culpabilidade, não se afirma que o sujeito pôde efetivamente atuar de outro modo - o que, indiscutivelmente, é impossível de se saber -, mas somente que havendo uma capacidade de autocontrole intacta - e com ela a acessibilidade normativa -, aquele deve ser tratado como livre.

Trata-se, portanto, de uma suposição de liberdade, caracterizada pelo doutrinador como uma "asserção normativa", vale dizer, uma regra social de jogo - cujo valor na sociedade é independente do problema de teoria do conhecimento e das ciências naturais -, segundo a qual o ordenamento jurídico deve partir do pressuposto de que as pessoas, em regra, possuem liberdade de vontade e de ação. Essa asserção normativa de que a pessoa (cuja capacidade psíquica de autocontrole está em ordem em uma determinada situação) pode atuar livremente está baseada em dois alicerces principais: de um lado, a autocompreensão natural do ser humano enquanto ser dotado de livre-arbítrio; e de outro, a impossibilidade de uma ordenação razoável da vida humana em sociedade sem a concessão recíproca de liberdade. Desses fatores decorreria a imprescindibilidade de o direito penal partir da premissa do livre-arbítrio, ainda que esse não possa ser demonstrado empiricamente.

Em suma, a culpabilidade roxiniana se apresenta como um dado misto empíriconormativo. Desde uma perspectiva, seria empiricamente constatável a capacidade geral de autocontrole e a acessibilidade normativa dela derivada. De outro panorama, se atribui 
normativamente a possibilidade, derivada dessa constatação, de conduta conforme ao Direito.

Por seguir sem resposta a questão do efetivo poder atuar de outro modo no caso concreto - até por tal problemática deixar de fazer sentido desde o modelo de responsabilidade proposto -, ROXIN argumenta que resulta definitivamente deslegitimada a culpabilidade calcada nas ideias de retribuição e de reprovação moral - as quais, ademais, teriam sempre se revelado questionáveis do ponto de vista político-criminal. Com a concepção formulada, o autor busca transformar a culpabilidade de uma ficção necessária para o Estado a uma suposição garantidora de liberdade, voltada à proteção dos cidadãos contra os excessos punitivos do Estado e à manutenção da persecução dos fins preventivos da pena aos limites próprios do Estado de Direito, servindo à construção de uma políticacriminal razoável.

\subsection{Considerações finais: indefinição a respeito do conteúdo da culpabilidade (dependência ou independência da ideia de livre-arbítrio)}

Do escorço apresentado, nota-se que a relação entre livre-arbítrio e culpabilidade é encarada de forma distinta nos diversos modelos de responsabilização penal subjetiva. Com efeito, a análise das características de cada proposta teórica estudada neste capítulo expressamente, a concepção normativa pura da culpabilidade e as construções pós-crise da culpabilidade finalista - permite que tais formulações sejam divididas em dois grandes grupos, a saber: $(i)$ o grupo dos modelos de culpabilidade em que o livre-arbítrio é tomado como seu pressuposto; e (ii) o grupo dos modelos de culpabilidade para os quais a existência de livre-arbítrio é, ao menos aparentemente, indiferente.

No primeiro grupo de modelos de culpabilidade (livre-arbítrio enquanto pressuposto da culpabilidade), situam-se as formulações teóricas de Hans WELZEL (concepção normativa, com os aportes finalistas) e Bernd ScHÜNEMANN (concepção "indeterminista"), além das construções de Urs KINDHÄUSER (concepção "comunitarista"), Eugenio Raul ZAFFARONI (culpabilidade por vulnerabilidade) e Claus ROXIN (culpabilidade como "acessibilidade normativa"). A despeito da semelhança que as une, há entre essas teorias uma diferença que as dissocia entre si (a saber: o livre-arbítrio como uma realidade concreta ou como uma suposição abstrata), de maneira que as concepções 
para as quais o livre-arbítrio fundamenta a culpabilidade podem ainda ser repartidas em dois subgrupos.

Em um subgrupo alocam-se as teorias dos dois primeiros autores, uma vez que, para ambos, a existência de livre-arbítrio é inconteste, não havendo de se questionar sua condição enquanto fundamento da culpabilidade. Nesse sentido, para WELZEL (1956, pp. 157 a 163), a despeito da estrutura causal dos atos do pensamento, há na configuração da vontade fundamentos inteligíveis determinantes, de modo que o livre-arbítrio se apresenta como a capacidade de o sujeito liberar-se da coação causal dos impulsos, autodeterminando-se conforme dada finalidade. A concepção de SCHÜNEMANN (2009, pp. 470 a 474), por outro lado, mais radical que a do professor de Bonn, está assentada no indeterminismo, lastreando-se na ideia de que o livre-arbítrio está provado por dois fatores principais: a experiência subjetiva de cada indivíduo e o reconhecimento recíproco, entre os indivíduos, da liberdade de vontade em nossa sociedade e cultura - liberdade essa que estaria expressa nas estruturas linguísticas.

No outro subgrupo encontram-se os demais autores mencionados, para os quais a existência de livre-arbítrio não pode ser empiricamente comprovada, mas deve ser presumida pelo direito penal, pois de outra forma a culpabilidade não se sustenta enquanto elemento do delito - e sua exclusão da estrutura de responsabilização criminal seria deletéria, em razão das garantias ao indivíduo que sua concepção aportou ao exercício do jus puniendi estatal. Assim, na compreensão de KINDHÄUSER (2011 [1], pp. 228 a 231), a culpabilidade não deve basear-se em assunções metafísicas, mas sim referir-se a uma práxis social, alicerçando-se em pressuposições de natureza normativa. Argumenta o autor que, tal como ocorre nas questões da vida cotidiana, no Direito a existência de livrearbítrio deve dar-se por suposta, sendo afastada apenas sob condições especiais, de maneira que a liberdade, definida normativamente, passa a significar a ausência das situações reconhecidas de falta de liberdade. A legitimidade dessa suposição universal de capacidade de seguir a norma - negada apenas em determinadas circunstâncias excepcionais - residiria na consideração do ser humano enquanto pessoa de direito, especificamente em seu duplo rol de criador e de destinatário da norma, cujo fundamento é idêntico. ZAFFARONI (2006, pp. 507 a 509), de seu turno, defende que todos os seres humanos contam com certo espaço de decisão, que não é infinito, nem idêntico em todas as circunstâncias. Dentre outros argumentos, sustenta que, conquanto o livre-arbítrio não seja empiricamente demonstrável, seria cientificamente verificável que na interação social as pessoas se comportam como se 
tivessem âmbitos de autodeterminação e que, com base nisso, fazem toda sorte de avaliações positivas e negativas; além disso, que a psicologia provaria que cada um de nós, segundo a nossa personalidade e as situações vivenciadas concretamente, temos um certo catálogo, ainda que limitado, de condutas possíveis. Ainda nessa linha, Roxin (1997, pp. 807 a 812) argui que a imprescindibilidade de o direito penal partir da premissa do livrearbítrio, ainda que esse não possa ser demonstrado empiricamente, está calcada na autocompreensão natural do ser humano enquanto ser dotado de livre-arbítrio e, também, na impossibilidade de uma ordenação razoável da vida humana em sociedade sem a concessão recíproca de liberdade.

No segundo grupo dos modelos de culpabilidade (existência de livre-arbítrio como indiferente à culpabilidade), encontram-se as teorias de Günther JAKOBS (culpabilidade como um déficit de fidelidade ao ordenamento jurídico) e Francisco MuÑOz CONDE (concepção "dialética" da culpabilidade), bem como as de Winfried HASSEMER (culpabilidade sem reprovação) e Enrique GIMBERNAT ORDEIG (prevenção por meio da pena).

Nos modelos dos dois primeiros autores, a questão da existência de livre-arbítrio deixa de fazer sentido em razão da substituição do critério nuclear de aferição da culpabilidade: do "poder agir de outro modo" (da teoria finalista) pela "motivação normal do agente". Na formulação de JAKOBS (1997, pp. 584 a 586; 2012, pp. 210 a 214; 1992, pp. 1081 a 1083), a responsabilização pessoal não é fundada na reprovabilidade do sujeito por sua conduta, mas na manutenção da ordem social diante da lesão da vigência da norma. Para o doutrinador, em um sistema jurídico-penal assim moldado, o único pressuposto da culpabilidade é que o sujeito possa ser, desde parâmetros cognitivos, motivado pela norma, de modo que não importa se a vontade do sujeito que praticou o injusto era livre, mas apenas se ela foi formada em condições de normalidade cognitiva. De outro turno, na construção de MUÑOZ CONDE (2007, pp. 140 a 144), em que a prevenção geral passa a compor a concepção de culpabilidade, o abandono do "poder agir de outro modo" se dá em razão da impossibilidade de sua demonstração. Assim, o fundamento material da culpabilidade deixa de referir-se à liberdade de vontade para voltar-se à função motivadora da norma penal, orientada à proteção de bens jurídicos e dirigida aos indivíduos capazes de motivarem seus comportamentos conforme os mandados normativos. Também aqui, a culpabilidade só será excluída ou diminuída nas hipóteses em que se verifique alguma 
alteração relevante na motivabilidade do sujeito - isto é, na capacidade de motivar-se pela exigências normativas.

De outra perspectiva, HASSEMER (1999, pp. 58 a 60) constrói uma concepção de culpabilidade em que a ideia de reprovação - a qual considera insustentável do ponto de vista teórico e prejudicial desde um panorama prático - é afastada, e na qual os limites da pena se deduzem dos critérios de proporcionalidade. Nesse modelo, a problemática que envolve o livre-arbítrio se mostraria irrelevante, pois a verificação da culpabilidade do autor do injusto se daria, por meio do processo penal e de seu instrumental, a partir da ausência de indicadores de déficit de liberdade no caso concreto. Segundo o autor, tais sinais não constituem, de fato, indícios negativos de liberdade de eleição e de ação, mas sim limites de criminalização próprios de um direito penal humano, estabelecidos pela experiência histórica - e por debates travados na teoria e na práxis -, consistentes na seleção de certas situações nas quais se demonstrou não ser exigível o comportamento conforme ao Direito. Com relação à proposta teórica de GiMBERnAT ORDEIG (1990, pp. 142 a 158), por fim, perde sentido a discussão acerca do livre-arbítrio na medida em que a culpabilidade, como um todo, é excluída da estrutura de responsabilização penal, cedendo lugar ao critério da necessidade de pena - essencialmente preventivo -, cujo escopo é o de reforçar a proibição de determinados comportamentos de especial gravidade e evitar, na maior medida possível, ações que ataquem os alicerces da convivência social.

Dessa breve análise se percebe o grau de indefinição que paira na doutrina a respeito do conteúdo da culpabilidade e de seu papel no direito penal. Retomando o raciocínio inicialmente delineado nas considerações introdutórias, parece nítido que as divergências conceituais acerca da culpabilidade e de seus fundamentos se devem, em larga escala, à polêmica sobre o livre-arbítrio e os mecanismos humanos de formação da vontade e de tomada de decisão. Há, nesse sentido, pelo menos duas grandes linhas de pensamento na doutrina penal no que atine à liberdade de vontade, com influência direta na estrutura de responsabilização penal subjetiva proposta: (i) a baseada em sua afirmação, que a encara como uma realidade concreta, sustenta sua existência e formula modelos de culpabilidade nela assentados; (ii) a não baseada em sua afirmação, que elabora estruturas de responsabilização penal indiferentes à demonstrabilidade empírica do fenômeno, seja por considerá-lo uma presunção necessária para o direito penal, seja por assentar a punição em outros fundamentos. 
Essa dissonância existente entre os estudiosos do direito penal reflete com fidelidade o dissenso que há acerca do tema em outras áreas do saber, especialmente a filosofia e a biologia. Em verdade, de uma maneira ou de outra - por vezes declaradamente, em outras não -, a discussão sobre o livre-arbítrio na ciência penal acabou por acompanhar o estágio de desenvolvimento da reflexão e das pesquisas naqueles campos do conhecimento, ora tendendo ao determinismo, ora pendendo ao indeterminismo, ora buscando uma posição equilibrada entre os extremos. Todavia, sem que se chegasse, ao menos até a atualidade, a um entendimento consensual.

Diante desse quadro de incerteza acerca da existência do livre-arbítrio humano - e de sua função na estrutura de responsabilização penal -, o desenvolvimento tecnológico logrou lançar uma nova luz à discussão. Com efeito, a evolução dos aparelhos de leitura e monitoramento da atividade cerebral elevou as investigações sobre o funcionamento do cérebro a um novo patamar de especialização. Isso permitiu que se passasse a estudar, com uma abordagem totalmente inovadora, os mecanismos de formação da vontade e de tomada de decisão, trazendo novos contornos ao milenar e transdisciplinar debate. E com os elementos aportados pela neurociência, surgiram também novos questionamentos: o que muda no que tange às atuais (coexistentes) compreensões filosóficas acerca do livrearbítrio? Qual o impacto das contribuições das pesquisas neurocientíficas nas formulações teóricas acerca da culpabilidade? Expressamente: alguma(s) delas é(são) compatível(eis) com essa nova realidade que se apresenta? São essas questões que guiarão o desenvolvimento da sequência do trabalho. 


\section{LIVRE-ARBÍTRIO E NEUROCIÊNCIAS}

\subsection{Considerações introdutórias: o livre-arbítrio como problema filosófico e a contribuição das ciências naturais}

O problema do livre-arbítrio é, talvez, o mais debatido dos problemas filosóficos na contemporaneidade. Não obstante, não se trata de questão filosófica nova, mas que remonta há séculos, tendo emergido, segundo Robert KANE (2002, pp. 4 a 6), no momento em que os seres humanos atingiram um certo nível de autoconsciência suficiente para compreender quão profundamente o mundo pode influenciar seu comportamento, de maneiras que até então não poderiam vislumbrar. Para KANE (2002, p. 5), identifica-se esse estágio de autoconsciência a partir do nascimento de um conflito entre duas perspectivas distintas - coexistentes, mas conflitantes - acerca do próprio ser humano e de seu lugar no universo: uma orientada no sentido de que temos liberdade de agir; outra no de que nossas ações estão determinadas por fatores alheios a nós.

Assim, desde um ponto de vista pessoal (ou prático), nós nos enxergamos como agentes livres, capazes de influenciar o mundo das mais diversas formas; parece-nos que podemos raciocinar e deliberar sobre as alternativas abertas que pairam a nossa frente; sentimos que cabe a nós decidir sobre a maneira como agimos e o que escolhemos - o que, em contrapartida, significa também que sempre há a opção de portar-se de modo diverso. Em suma, essa sensação interna de liberdade nos sugere que as origens ou as fontes de nossas ações residem em nós mesmos, e não em outro ente sobre o qual não temos controle - seja ele Deus ou o destino, as leis da natureza, ou mesmo outros seres humanos.

De acordo com o autor, essas duas características fundamentais da perspectiva pessoal (ou prática) - isto é, a percepção de que cabe a nós escolher uma dentre várias alternativas possíveis, além da impressão de que nossas escolhas e ações derivam de nós mesmos - são essenciais na configuração do conceito tradicional de livre-arbítrio. Em razão delas, a ideia de livre-arbítrio é frequentemente associada a outras noções igualmente importantes, como a responsabilidade moral, a autonomia, a criatividade, o autocontrole, a dignidade e o mérito por nossas ações e realizações. Igualmente com base nessas características é que se construiriam socialmente as atitudes reativas - vale dizer, os atos ou sentimentos em resposta à conduta de outrem -, tais como a gratidão, o ressentimento, a admiração e a indignação. Em outras palavras, essas manifestações, dirigidas a outras 
pessoas por conta de seu comportamento, constroem-se a partir da premissa de que essas pessoas puderam escolher esses comportamentos (KANE, 2002, p. 5).

De outro lado, de uma perspectiva impessoal (ou objetiva, ou teorética) - expressa, por exemplo, na análise de uma sucessão de acontecimentos relacionados, a partir de um ponto de vista externo -, podem surgir impressões como a de que, na verdade, as ações humanas são causadas por forças físicas sobre as quais não temos controle; ou a de que nossas escolhas, dentre as várias alternativas aparentemente possíveis, são determinadas por motivos inconscientes, ou por estímulos psicológicos de ação sobre os quais não temos ciência. Preponderantes para o aperfeiçoamento desse pensamento foram algumas descobertas científicas, como a de que muito do caráter e do comportamento humano é influenciado pela hereditariedade e pelo ambiente, e a de que o pensamento e as atitudes humanas podem ser dissimuladamente influenciados por condicionamento social ou por sutis desequilíbrios químicos de neurotransmissores ou hormônios (KANE, 2002, p. 5).

É com o surgimento dessa perspectiva (impessoal) que o livre-arbítrio torna-se uma questão nas diversas áreas do saber, dando ensejo à formulação de teorias que põem em xeque a ideia da liberdade de vontade, como as doutrinas do determinismo ou da necessidade, as quais assumem, historicamente, diversas figuras - fatalista, teológica, física (ou científica), psicológica e lógica. Comum a todas elas, há a noção nuclear de que qualquer evento é determinado por condições pré-existentes - sejam elas os desígnios do destino, os atos de pré-ordenação divina ou o antecedente causal físico regido pelas leis da natureza -, cuja presença conjunta é (logicamente) suficiente para sua ocorrência, a qual, ademais, é inevitável dadas essas condições determinantes. As variadas doutrinas do determinismo referem-se, cada qual, a diferentes tipos de condições determinantes, mas é inerente à universalidade delas a ideia de que todo e qualquer evento - incluindo as escolhas e ações humanas - é determinado de acordo com esse modelo.

A consolidação do livre-arbítrio enquanto problema científico, além de filosófico, passa a impactar uma série de discussões, nas mais diversas disciplinas do conhecimento, sobre questões como: (a) a ação e a responsabilidade moral, a dignidade, o mérito e a culpa - na ética; (b) a natureza e os limites da liberdade e autonomia humanas, da coerção e do controle - nas ciências sociais e política; (c) a compulsão, o vício, o autocontrole, o autoengano, a fraqueza de vontade - na psicologia; (d) a relação entre mente e corpo, a consciência, a natureza da ação e a personalidade - na filosofia da mente e na neurociência cognitiva; (e) a natureza da racionalidade e da escolha racional - na filosofia e na teoria 
social; (f) a liberdade humana, os desígnios divinos, a predestinação - na teologia; e, especialmente, $(\mathrm{g})$ a responsabilidade criminal e a imposição de pena - no direito penal (KANE, 2002, p. 4).

À parte as várias repercussões possíveis nas diferentes áreas do saber, os debates acerca do livre-arbítrio na era moderna - desde o século XVII - tem sido orientados não por um, mas por dois questionamentos: o "questionamento determinista" ("A teoria determinista é verdadeira?); e o "questionamento compatibilista" ("O livre-arbítrio é compatível - ou não - com o determinismo?). De um modo geral, essas questões permearão o desenvolvimento deste capítulo, a partir da discussão acerca dos pressupostos filosóficos e científicos embasadores das duas grandes linhas de pensamento na doutrina jurídicopenal no que diz respeito ao livre-arbítrio - a que se baseia em sua afirmação e a que não se baseia $^{45}$-, assim como dos aportes do estudo do cérebro ao assunto.

\subsection{Fundamentos filosóficos e científicos do pensamento penal baseado na afirmação do livre-arbítrio}

4.2.1. Possibilidade de liberação causal dos impulsos (autocontrole): WELZEL

Como apresentado no capítulo "3.3.3. O finalismo e a concepção normativa pura da culpabilidade", a culpabilidade welzeliana assenta-se na ausência de autodeterminação conforme o sentido em um sujeito que tinha capacidade para tanto, e incide sobre a formação de sua vontade, de maneira que o agente é reprovado por não haver reprimido os impulsos adversos - isto é, por ter se omitido com relação à condução por impulsos contrários ao valor (WELZEL, 1956, pp. 161 e 162). Essa concepção está calcada na posição intermediária - entre determinismo e indeterminismo - adotada por WELZEL (1956, pp. 161 e 162) com relação ao livre-arbítrio, que, por um lado, reconhece a estrutura causal dos atos do pensamento, mas que, por outro, admite a possibilidade, pelo ser humano, de liberação da coação causal dos impulsos, voltada à autodeterminação conforme dada finalidade.

\footnotetext{
45 Detalhadamente: (i) linha baseada na afirmação do livre-arbítrio, que o encara como uma realidade concreta, sustenta sua existência e formula modelos de culpabilidade nele assentados; e (ii) linha não baseada na afirmação do livre-arbítrio, que elabora estruturas de responsabilização penal indiferentes à demonstrabilidade empírica do fenômeno, seja por considerá-lo uma presunção necessária para o direito penal, seja por assentar a punição em outros fundamentos.
} 
A despeito de embasada, em última análise, na ideia de autocontrole, a teoria finalista de WeLzEL passa ao largo de explicar, como bem observa JESCHECK (2003, pp. 5 e 6), de que forma o sujeito exerce, de fato, essa capacidade de contenção de seus ímpetos para evitar o delito e atuar conforme ao Direito. Essa lacuna da teoria welzeliana é de certa forma reconhecida por seu próprio formulador, que assinala não ser possível responder à pergunta de como o homem está em condições de libertar-se do estímulo causal voltandose a uma autodeterminação adequada ao sentido, assim como não haveria resposta à pergunta de como a causa vem a produzir o efeito (WELZEL, 1956, p. 162).

Não obstante deixe de adentrar a fundo na discussão acerca da noção de autocontrole, limitando-se apenas a afirmar seu papel no processo de formação da vontade, WELZEL dá pistas sobre a origem dos fundamentos que o levaram a sustentar tal ideia, colocando-a em posição nuclear em sua teoria do delito. Com efeito, o autor utiliza como referências de sua doutrina da ação finalista pensadores consagrados que cuidaram da questão, como Aristóteles (Welzel, 1951, p. 18) e Nicolai HARTMANN (WelZEL, 1956, p. 161). A partir das concepções desses autores, buscar-se-á analisar a viabilidade da ideia de autocontrole enquanto fundamento da existência de livre-arbítrio e, consequentemente, da responsabilidade penal.

A contribuição de ARISTÓTELES ao problema do livre-arbítrio está expressa em sua obra "Ética à Nicômaco" e consiste no estudo de três questões fundamentais: (i) sob quais condições pode-se considerar que os seres humanos atuam sem liberdade de vontade; (ii) se o homem que age perversamente e realiza más ações atua voluntariamente - isto é, com liberdade de vontade; e (iii) se o homem pode ter sabedoria moral e ser incontinente (no sentido de lhe faltar autocontrole), vale dizer, se é possível que o homem faça aquilo que sabe ser errado e condena (DILMAN, 2001, p. 65). Conquanto se tratem de questionamentos relativamente independentes, estão interligados, de maneira que, para uma análise adequada da formulação aristotélica acerca do papel do autocontrole na formação da vontade, se revela necessária uma compreensão geral, ainda que superficial, da concepção do filósofo sobre o fenômeno do livre-arbítrio.

De início, é importante ressaltar que a problemática acerca da existência do livrearbítrio não é abordada por ARISTÓTELES, que toma tal conceito como premissa por aceitálo como realidade. Sua preocupação, em um primeiro momento, é a de demonstrar os limites do livre-arbítrio: quando, sob quais condições, pode-se dizer que um sujeito agiu 
"voluntariamente", isto é, com liberdade de vontade? E em que hipóteses suas ações não são livres, apesar de intencionais?

Antes de chegar a tais questionamentos, o filósofo grego inicia sua obra apresentando sua noção de ser humano, a partir de certas características que o definiriam como tal. Valendo-se de analogias, argumenta que assim como o carpinteiro e o curtidor de couro têm missões e atividades que lhe são peculiares, do mesmo modo também ocorre com o "ser humano enquanto ser humano". No mesmo sentido, acrescenta que assim como os olhos, as mãos e os pés possuem funções próprias, o mesmo vale para o "homem como um todo". Para o pensador, é traço distintivo do ser humano não ter vindo ao mundo tão somente para sobreviver - qual um vegetal - ou para experienciar uma vida de ações baseadas em sensações e instintos - como a maioria dos animais -, mas para perseguir fins conforme a razão, agindo de acordo com escolhas baseadas em intenções. Em suas palavras, "a função do homem é uma atividade da alma segundo a razão" (ARISTÓTELES, 2001, pp. 26 e 27).

Nessa linha, ARISTÓTELES (2001, p. 27) assinala que a função do bom homem é uma realização nobre e satisfatória de sua atividade racional - que deve ser executada com a excelência que lhe é própria -, de maneira que o bom homem vem a ser o resultado da atividade da alma em consonância com a virtude ${ }^{46}$ - e, se houver mais de uma virtude, de acordo com a melhor e a mais completa delas. Conforme nota Ilham DiLMAN (2001, p. 49), a despeito de afirmar que o bom homem exerce de forma nobre e satisfatória sua atividade racional, o pensador grego deixa de apresentar normas ou critérios de ponderação acerca da excelência da racionalidade. Em outros termos, se está claro, na obra daquele autor, que viver racionalmente a vida - isto é, viver uma vida de razão -, significa colocar em prática a habilidade humana de deliberar, de fazer escolhas e de tomar decisões, não resta manifesto, em ARISTÓTELES, no que isso exatamente consiste, dada a dificuldade em se caracterizar e se categorizar virtudes.

Apesar dessa lacuna, o trabalho do filósofo ateniense segue com a proposição de que o processo de tomada de decisão nos humanos é orientado por três objetos de escolha e três de rejeição, respectivamente: o nobre, o vantajoso e o agradável; e seus opostos, o vil, o prejudicial e o doloroso. Com relação a todos eles, segundo o autor, o homem bom tende a agir certo e o homem mau a agir errado (ARISTÓTELES, 2001, p. 44). ARISTÓTELES (2001,

\footnotetext{
${ }^{46}$ No sentido de disposição permanente para querer cumprir uma espécie determinada de atos morais. As virtudes morais, em ARISTÓTELES, são aquelas que têm como objeto os atos da vida prática, voltados à justiça, magnanimidade, liberalidade, coragem, amizade (LALANDE, 1993, p. 1.219).
} 
p. 46), ademais, considera que a alma é formada por três estratos: as paixões (ou apetites) isto é, os sentimentos que são acompanhados de prazer ou sofrimento (a cólera, o medo, a audácia, a inveja, a alegria etc.); as faculdades - ou seja, a aptidão ou capacidade de sentir as paixões (faculdade de magoar-nos, de compadecer-nos etc.); e as disposições - vale dizer, os fatores que definem se nossa posição em relação às paixões é boa ou é má (por exemplo, com relação à cólera, nossa posição é má se a sentimos de modo violento ou, opostamente, de modo muito fraco, e boa se a sentimos moderadamente).

Partindo dessas concepções preliminares, ARISTÓTELES (2001, pp. 56 e ss.) passa a analisar efetivamente a primeira questão fundamental de seu estudo acerca do livre-arbítrio ("sob quais condições pode-se considerar que os seres humanos atuam sem liberdade de vontade"), voltando-se ao estabelecimento de uma distinção entre o que é feito de acordo com a vontade do sujeito ("voluntariamente", na denominação do autor) e o que é realizado sem a vontade do agente ou com uma vontade ou consentimento formados sem conhecimento, a partir de uma situação de ignorância (ou seja, "involuntariamente").

Nessa senda, dada a compreensão aristotélica pró existência de livre-arbítrio, a voluntariedade das condutas humanas é tomada como regra, sendo definida como a qualidade das ações cujo princípio motor está no próprio agente, quando esse tenha conhecimento da conjuntura particular em que está inserido (ARISTÓTELES, 2001, p. 59). De outro lado, são consideradas involuntárias as ações realizadas sob compulsão ou por ignorância. No primeiro caso, não há vontade do agente, que é forçado por circunstâncias externas ao cometimento do ato, enquanto na segunda hipótese a vontade do sujeito encontra-se caracterizada, mas está enviesada, uma vez que formada em um contexto de desinformação a respeito das circunstâncias do fato (ARISTÓTELES, 2001, p. 56).

Acerca das ações involuntárias realizadas sob compulsão, a responsabilidade do sujeito seria mínima, ainda que esse viesse a se sentir muito mal por ter sido o instrumento por meio do qual o resultado (indesejado) se materializou, ou mesmo por não ter tido capacidade de resistir à coação. A respeito das ações involuntárias por ignorância, ARISTÓTELES (2001, pp. 58 e 59) as divide em duas categorias: as realizadas em razão da ignorância; e as realizadas com ignorância (como aquelas nas quais o agente encontra-se embriagado ou enfurecido). Na primeira hipótese, o filósofo considera que há responsabilidade do sujeito apenas se sua ignorância for culpável, vale dizer, se derivar de uma situação de negligência - ou outra espécie de descuido. No segundo caso, dado que a causa do ato não é a ignorância, mas a embriaguez ou a fúria, há responsabilidade do 
sujeito por ter atingido tais estados, chegando o autor clássico, inclusive, a questionar se tais as ações, cometidas nessas circunstâncias, deveriam ser classificadas como involuntárias.

Conquanto entenda que a ignorância (no sentido de falta de informação ou de conhecimento de dados específicos) em uma dada conjuntura pode levar à prática de certos atos involuntariamente, o pensador ateniense esclarece que ignorância não é o mesmo que involuntariedade. Conforme observa DiLmAN (2001, p. 51), com esse posicionamento ARISTÓTELES (2001, p. 58) afasta-se da compreensão de seu mentor, PLATÃO, para quem todo homem ruim é ignorante a respeito do que deveria fazer e deixar de ser feito, de maneira que ninguém causaria um mal voluntariamente. Na concepção do discípulo, não se aplica o termo involuntariedade ao homem que permanece ignorante (com relação a conhecimentos universais) por seu próprio e verdadeiro interesse. Em seu entendimento, a ignorância que afeta a escolha moral (relacionada a valores e saberes gerais) constitui degeneração, e não involuntariedade - a qual se configuraria apenas se verificada a ignorância dos particulares, isto é, das circunstâncias da ação e dos objetos a essa relacionados.

Com isso, ARISTÓTELES (2001, p. 60) assere que a escolha moral é claramente um ato voluntário. Para o autor, quando uma pessoa faz uma escolha - seja ela moral ou não está exercendo sua vontade. Seu argumento é que o processo de deliberação e decisão representa, por excelência, o exercício da vontade. Considerando que a escolha moral é uma espécie de escolha, será necessariamente voluntária - independentemente se feita por uma pessoa boa ou má. Tendo em consideração que deliberamos sobre questões práticas que estão a nosso alcance e que podem ser realizadas, bem como que refletimos e decidimos sobre os meios para atingir certos fins - determinados, em última instância, por nossos desejos -, o pensador grego argui que nossas ações devem concordar com nossa escolha e ser voluntárias. Levando em conta, ainda, que a virtude e o vício estão ao nosso alcance, por estarem relacionados com os meios eleitos para atingir os fins pretendidos, e que depende de nós tanto o agir, quanto o deixar de agir, conclui o filósofo que está em nossas mãos praticar atos nobres ou vis, tornando-nos virtuosos ou viciosos (ARISTÓTELES, 2001, pp. 62 a 65).

Aqui, alcança-se a segunda contribuição de ARISTÓTELES (2001, pp. 65 a 68) ao estudo do livre-arbítrio, atinente à questão de "se o homem que age perversamente e realiza más ações atua voluntariamente - isto é, com liberdade de vontade". Para o discípulo de 
PlatÃo, resta claro que as ações de um homem mau são intencionais, uma vez que deliberando, tomando decisões e realizando suas ações perversas estaria usando sua inteligência e seu poder de razoar. E esses seriam os únicos requisitos para tornar sua ação voluntária. Assim, segundo esse autor, não haveria distinção entre os homens bons e os ruins com relação à tomada de decisão, pois ambos fariam escolhas, em determinadas circunstâncias, de modo voluntário, conforme suas próprias faculdades mentais e em consonância com o tipo de pessoa que são.

Além de atribuir a realização de atos vis à ignorância acerca das virtudes morais - a despeito de isso não significar involuntariedade na prática de tais ações -, ARISTÓTELES (2001, pp. 145 e ss.) considera que também o autocontrole (ou autodomínio, ou continência $^{47}$ tem importante papel na tarefa de se fazer o que é certo e bom. Observando que há pessoas que, apesar de identificarem corretamente o que é virtuoso e, portanto, saberem o que devem fazer, falham em seguir tal caminho - às vezes realizando exatamente o oposto -, o filósofo grego divide os seres humanos em duas categorias : (a) os que tem autocontrole (ou "continentes"); e (b) aqueles cujo autocontrole é imperfeito (ou "incontinentes"). No caso desses, o que os levaria a cometer atos ruins não seria a falta de sabedoria moral (ignorância), mas a ausência de força de vontade.

Segundo o pensador ateniense, o homem que tem autocontrole é aquele que está apto a honrar suas deliberações; é aquele que, percebendo a perversidade de seus desejos, recusa-se, por meio do exercício da razão, a deixá-los prevalecer. No homem autocontrolado, revela-se eficaz o uso da razão e sua tarefa de guiar a vontade, impedindoo de ceder a seus desejos em determinadas situações. Para o filósofo, além do autocontrole, a perfeita continência é composta também da qualidade da resistência, já que o ser humano não é, em regra, insensível ao perigo, aos apetites e à provocação - sem essa sensibilidade, aliás, seria impossível tornar-se virtuoso -, devendo ser forte para não sucumbir a eventuais tentações de fazer aquilo a que é moralmente contrário (ARISTÓTELES, 2001, pp. 146 a 148).

Em oposição, o homem cujo autocontrole é imperfeito age instigado por suas paixões, ainda que sabendo serem elas moralmente erradas. O que lhe falta não é conhecimento ou informação, mas autodisciplina e freios. Apesar de ter sabedoria moral, o incontinente não consegue acessá-la no momento do ato. Em outras palavras, conquanto a virtude não esteja ausente no incontinente, esse se afasta daquela eventualmente, em dadas

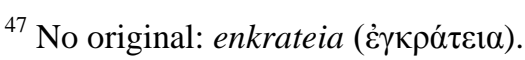


ações, sob certas circunstâncias. Não se trata de um sujeito injusto, portanto, mas que pratica atos injustos em ocasiões nas quais deixa suas paixões prevalecerem (ARISTÓTELES, 2001, pp. 148 a 152).

Chega-se, então, à terceira contribuição de ARISTÓTELES ao estudo do livre-arbítrio, relativa ao questionamento de "se o homem pode ter sabedoria moral e ser incontinente (no sentido de lhe faltar autocontrole), vale dizer, se é possível que o homem faça aquilo que sabe ser errado e condena". Conforme acima exposto, responde o pensador afirmativamente a essa questão. Concebendo o autocontrole não como um ato temporário, mas como uma condição da alma, entende que quando ele é imperfeito, deixa eventualmente de se manifestar, levando o sujeito a permitir que seus impulsos controlem suas ações, ainda que essas sejam contrárias àquilo que sabe ser o certo a ser feito no caso concreto.

Cerca de dois milênios depois de ARISTÓTELES, já no século XX d. C., outro autor expressamente referido por WELZEL como influência na construção de sua estrutura da ação finalista, Nicolai HARTMANN, promove, em sua obra "Ethik" (ou "Ética"), uma retomada da questão da função do autocontrole (ou autodomínio, ou continência) na formação da vontade humana ${ }^{48}$. Como o próprio nome do trabalho de referência evidencia, a concepção do filósofo alemão acerca daquele fenômeno está inserida no contexto da formulação de sua ética, sobre a qual se mostra necessário debruçar inicialmente, ainda que de modo perfunctório.

A ética de HARTMANN é composta por uma teoria geral dos valores, aliada a uma penetrante descrição de sua experiência. Na análise de Roberto POLI (2014), a teoria ética do professor de Göttingen pode ser sintetizada em quatro aspectos básicos, vale dizer: (a) o uso da ontologia como um meio de compreender os valores; (b) a estrutura bidimensional dos valores; (c) os valores enquanto demanda; e (d) a articulação estrutural do caráter.

Com relação ao primeiro aspecto ("o uso da ontologia como um meio de compreender os valores"), parte da assunção, por HARTMANN, de que os valores (morais) são entes ideais. Seguindo a tese de que há ao menos duas espécies principais de entes

48 Conforme observa Víctor Gabriel RoDRíGueZ (2014, pp. 136 a 142), a contribuição da construção filosófica de HARTMANN à teoria welzeliana extrapola a questão do autocontrole. Segundo o professor de Ribeirão Preto, a explicação do filósofo alemão sobre a conciliação entre o homem moral e o homem físico, por meio de estratos que conformam a pessoa - a permitir que convivam livre-arbítrio e determinantes físicas - foi marcante no desenvolvimento do finalismo penal, de maneira que sua ontologia (e, dentro dessa, sua teleologia) exerceu influência não apenas em WELZEL, mas em contemporâneos como Edmund MEZGER. 
ideais - além dos valores morais, os valores matemáticos -, o autor alemão busca identificar quais qualidades, além da atemporalidade, lhe são comuns. Dessa investigação, três características gerais emergem, no entendimento do filósofo: $(i)$ o desconhecimento acerca da geografia global tanto dos valores matemáticos, quanto dos valores morais - isto é, apesar dos esforços dos estudiosos ao longo da história, apenas parte do território de ambos os entes foi explorado e mapeado, restando seus domínios ainda longe de serem completamente identificados e traçados; (ii) a longa distância que separa tais entes da esfera do ser real - vale dizer, várias estruturas matemáticas estão muito distantes de serem exemplificadas no mundo real, e o mesmo também se aplica aos valores morais; e (iii) tanto a matemática, quanto a ética, reclamam a universalidade de suas normas (o que é próprio de sua natureza enquanto seres ideias), mas, por outro lado, nenhuma das duas é capaz de captar, de sua perspectiva, a realidade como um todo - ou seja, não há um único modelo matemático do mundo, assim como não há uma única compreensão ética de toda a experiência humana (POLI, 2014).

No que atine ao segundo aspecto ("a estrutura bidimensional dos valores"), HARTMANN propõe que os valores pertencem a diferentes famílias. Segundo sua formulação, para categorizar os valores em grupos, dois critérios são de maior relevância: o da força e o da estatura, sendo que o primeiro indica a gravidade da violação daqueles e o segundo dá a medida do mérito por seu cumprimento. Assim, esses dois critérios operariam em direções opostas: os valores mais fortes são também os mais baixos, enquanto os mais altos são também os mais fracos. Ainda de acordo com a concepção do pensador alemão, os valores mais baixos seriam mais simples - isto é, teriam conteúdo mais intuitivo -, ao passo que os de maior estatura ostentariam complexidade mais elevada. Nessa linha, as leis de força e estatura teriam como consequências mais importantes as seguintes: (i) a violação a um valor mais baixo representaria um mal maior do que a violação de um valor mais alto; e (ii) o cumprimento de um valor mais alto significaria um bem maior do que o cumprimento de um valor mais baixo ${ }^{49}$.

\footnotetext{
${ }^{49}$ Em outras palavras, transgredir valores mais baixos se mostraria infame, vergonhoso, revoltante, mas seu cumprimento só atingiria o nível da decência, da dignidade. Por outro lado, ofender valores mais altos teria, de fato, o caráter de falha moral, mas nada próximo à degradação, ao passo que a realização desses valores traria algo de edificante, libertador (HARTMANN, 2011, pp. 313 a 315). HARTMANN (2011, pp. 637 a 644) ilustra essa assertiva por meio dos exemplos do heroísmo (valor alto) e da confiança (valor baixo). Enquanto o exercício dessa proporciona (meramente) respeito, sua falta gera ira e desdém. Por outro lado, a realização de um ato daquela natureza garante admiração, mas sua falta não desperta desprezo, nem indignação. No mesmo sentido, uma ofensa contra a vida é algo certamente grave, ao passo que o respeito a tal valor carrega pouco mérito em si. De outro turno, a satisfação de valores espirituais é um mérito muito maior do que aquele correspondente à sujeição a valores mais básicos. Dessa maneira, os que violam valores mais baixos
} 
Segundo Roberto POLI (2014), essa estruturação em níveis (ou graus) se mostra relevante não apenas por nos fornecer as leis estruturais que governam os valores, mas também por nos oferecer critérios para distinguir, em alguns casos, os valores autênticos dos falsos valores. E, com efeito, ao menos uma daquelas leis estruturais teorizadas por HARTMANN é bem conhecida na prática: a da arquitetura dos valores baseada em níveis de dependência, nos quais os valores mais baixos se desenvolvem em estágios intrinsecamente ligados até os valores mais altos - isto é, os valores são construídos passo a passo, do mais elementar aos mais secundários. Em termos concretos, essa norma permite identificar que uma pessoa cujo comportamento é orientado para um valor mais elevado, mas que, simultaneamente, não respeita os valores que o suportam, é um incoerente em essência.

No que tange ao terceiro aspecto ("os valores enquanto demanda"), representa a noção de que certos valores teriam a natureza ontológica de demandas. Essa concepção parte do pressuposto de que os valores, na qualidade de entes ideias, não mudam, e o que pode variar é o nosso acesso a eles, a depender de como nossa percepção pessoal evolui com o tempo e o amadurecimento axiológico. E considera, ainda, que grupos e comunidades se transformam ao seguir diferentes valores norteadores.

Dessas condições deriva, na compreensão de HARTMANN, que a interação entre os sujeitos e os coletivos a que pertencem proporciona momentos de estabilidade na seleção mutuamente ajustada de valores compartilhados. Assim, repetidos atos de valoração tenderiam a produzir ordens fixas ou estáveis de preferências individuais ou sociais, nas quais haveria uma pressão reciprocamente partilhada para que seus valores norteadores fossem realizados. E são justamente esses valores - os que se espera (e se estimula para que) sejam cumpridos - aqueles que ontologicamente apresentam a natureza de demandas. Tais demandas funcionariam de uma maneira dupla, a depender das mencionadas leis de força e de estatura dos valores: de um lado, promovendo, usualmente, a rejeição de novas visões - e de seus comportamentos correspondentes -; de outro, todavia, permitindo, eventualmente, sua aceitação, contribuindo com posturas formadas por valores diferentes (PoLI, 2014).

O quarto aspecto ("a articulação estrutural do caráter"), por fim, traz a ideia de que o caráter é definido, em última análise, pela posição que se assume perante os valores. Essa

são considerados perversos, mas o inverso não se sustenta, pois uma pessoa que viola os valores mais altos, aquela que falha em cumpri-los, não é tomada como um ser humano ruim, já que sua conduta não ameaça ninguém, estando ausente nessa situação, tão somente, um conteúdo moral de maior envergadura. 
afirmação tem como base a concepção de que os valores são acessados por meio de atos emocionais ou egológicos, os quais seriam estruturados em níveis de profundidade, daqueles que transmitissem informações mais superficiais àqueles que carregassem consigo dados mais íntimos. Haveria, assim, três diferentes níveis de experimentação dos valores: (i) o da percepção sensorial - que seria a camada mais externa (superficial), concernente a informações sobre como sentimos nosso corpo (por exemplo, sentir frio ou calor, estar passando bem ou mal etc.); (ii) o do "estado de espírito" - isto é, a camada intermediária, referente a dados sobre nosso ânimo ou humor (por exemplo, sentir-se entediado, excitado, relaxado, enfurecido etc.), a qual teria constituição dupla, parte orientada pelo corpo, parte orientada pela mente; e (iii) o do caráter - vale dizer, a camada mais profunda, relacionada ao estilo pessoal de ser, à forma como o indivíduo reage ao que acontece consigo (por exemplo, em uma situação de dor, pode-se tolerá-la, combatê-la, aceitá-la ou até mesmo aproveitá-la).

$\mathrm{Na}$ filosofia de HARTMANN, o caráter é definido pelas atitudes do sujeito, medidas a partir de seis grandes parâmetros, cada qual se estendendo de um mínimo a um máximo: $(i)$ abertura (no sentido de tomada de posição ou de comprometimento) ou oclusão (significando indiferença, inatividade ou apatia) perante o ambiente e outras pessoas; (ii) automutabilidade (capacidade de o indivíduo transformar seu próprio feitio); (iii) susceptibilidade à influência externa (capacidade de o ambiente e de outras pessoas modificarem o feitio do indivíduo); (iv) perspectiva de futuro (ter visões estreitas ou amplas acerca das possibilidades no horizonte); e $(v)$ foco e iniciativa (no sentido de traçar metas e de buscar os meios para atingi-las). Para o filósofo alemão, cada uma dessas dimensões consiste em um espectro contínuo que vai de um extremo valor a um extremo desvalor, no qual há pontos de quebra - limiares - em que valores se transformam diretamente em desvalores. Por trás dessa estrutura, haveria a possibilidade de escolha de certos valores que orientam internamente a pessoa, relativos, por exemplo, à opção entre o altruísmo e o egoísmo, ou entre o individualismo e a solidariedade (PoLI, 2014).

No âmbito de sua teoria ética, HARTMANN (2011, pp. 388 a 391) coloca essa capacidade de eleição ou, apropriadamente, a liberdade de vontade, como um valor básico da condição humana, inerente ao indivíduo. Na concepção do autor, o homem se diferencia, de modo mais profundo, dos seres de outras espécies em razão de não estar forçado a cumprir as determinações que recebe dos princípios que lhe orientam - no caso, os valores morais -, conservando o poder de agir a favor ou contra tais elementos 
norteadores de sua conduta. Segundo o filósofo, a vontade livre do ser humano é o que liga o reino dos valores à realidade, de maneira que o sujeito, diante da possibilidade de escolher atuar em favor dos valores, tornando-os seus, translada-os à esfera do real. Nessa linha, o valor do livre-arbítrio - enquanto autodeterminação na orientação de atos eticamente intencionais até determinado fim - residiria na possibilidade de romper com o cego funcionamento do mundo, de elevar o homem acima das conexões naturais às quais está arraigado.

Em termos concretos, conforme elucida Víctor Gabriel RoDRíGUEZ (2014, pp. 136 a 142), a possibilidade de eleição de condutas derivaria diretamente da disposição estratificada do ser humano, cujo comportamento seria formado por meio de uma cadeia de fatores: no primeiro estrato, que é causal, existiria uma determinação regida pela lei natural; no segundo estrato, que é final (teleológico), atuaria uma determinação segundo as "leis de dever", constituídas a partir dos valores humanos; e, no terceiro estrato, haveria um espaço de determinação livre, onde, a despeito das influências exercidas pelas demais camadas do ser, a vontade seria efetivamente formada. Assim, apesar de não conseguir criar o processo causal - já que esses são dirigidos pelas leis naturais -, o ser humano tem a capacidade de, referenciado por valores, desviá-lo a determinados fins, o que faz com que possa predeterminar o curso dos acontecimentos - residindo aí, portanto, seu intervalo de liberdade de vontade.

Para a realização do valor do livre-arbítrio, o exercício de outro se mostra imprescindível: o do autocontrole. Considerado por HARTMANN (2011, pp. 472 a 476) um valor moral especial de primeira grandeza - atrás em importância apenas dos valores morais elementares -, o conceito é o mesmo trabalhado por ARISTÓTELES, consistente na

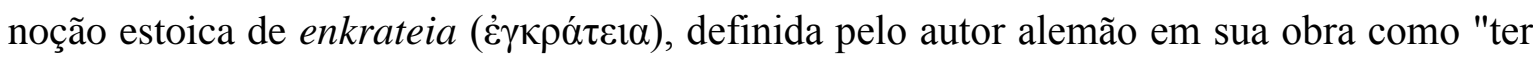
o poder sobre si mesmo" ou "ser o senhor de si mesmo". Nesse sentido, defende o filósofo contemporâneo que o autocontrole (ou continência) não deve ser entendido de maneira puramente negativa, como uma repressão interna - o que pressuporia que o natural, o instintivo, fosse exclusivamente mau -, mas como uma formação e conformação interior de toda a natureza do homem, de todos os poderes obscuros inerentes à condição humana que ascendem da inconsciência à consciência na forma de dados. A parte negativa da continência se dirigiria unicamente contra a intemperança e o desequilíbrio, ao passo que seu sentido positivo - o autocontrole em sentido estrito - apareceria como o poder sobre as 
afeições, como a virtude da proporção interior, constituindo-se em uma espécie de ordem e justiça interna.

A virtude da continência, para HARTMANN (2011, pp. 472 a 476), tem por traço peculiar a possibilidade de poder ser adquirida e formada - inclusive por meio do processo de educação. Além disso, seria o mais baixo dentre os valores da virtude, o mínimo que o ser humano pode requerer a si mesmo, pois somente alicerçado no autocontrole teria a possibilidade alcançar tarefas morais mais elevadas. Ainda de acordo com esse pensador, o caráter de base moral e a moldabilidade do autocontrole fazem com que tenha por função o desempenho de tarefas educativas eminentemente positivas, como por exemplo, para as crianças, as lições de superação dos próprios limites, de obediência, de domínio dos impulsos em benefício dos objetivos da vontade, enfim, de disciplina interior, a qual deságua, necessariamente, na sujeição a si mesmo e na direção de si próprio.

As formulações filosóficas de ARISTÓTELES e de Nicolai HARTMANN a respeito do autocontrole, no contexto de suas respectivas teorias éticas, têm como nítido enfoque apresentar o relevante papel dessa virtude humana na tarefa de fazer prevalecer, nos processos de tomada de decisão, as vontades racionalmente formadas, e assim permitir que as ações de cada indivíduo sejam orientadas pelos valores morais, contribuindo, em última análise, com a formação de seu caráter. Tendo isso em vista, nota-se que a despeito de o trabalho de tais autores ter sido referência para a construção da doutrina da ação finalista de WelzEL, seus estudos acerca do autocontrole não são suficientes para explicar de que forma o sujeito exerce, de fato, a capacidade de contenção de seus ímpetos para evitar o delito e atuar conforme o Direito, premissa na qual se sustenta, afinal, a culpabilidade finalista. Em outras palavras, permanece uma lacuna no questionamento - ao qual o próprio WELzEL (1956, p. 162) assumiu não ter resposta - de como o homem está em condições de libertar-se do estímulo causal, voltando-se a uma autodeterminação adequada ao sentido.

Diante desse quadro, para uma análise mais apropriada da viabilidade da tese do autocontrole enquanto fundamento da existência de livre-arbítrio e, consequentemente, da responsabilidade penal, se mostra necessário investigar os mecanismos pelos quais se procede a tomada de decisão no ser humano e de que maneira tal aptidão opera nos processos de deliberação e de realização da ação. Com esse idêntico propósito, uma série de pesquisas de neurociência foram estruturadas e levadas a efeito, trazendo novos subsídios ao debate filosófico em torno da liberdade de vontade. Assim, considerando que 
a questão do autocontrole e de suas implicações para o livre-arbítrio e a responsabilidade penal pode ser enriquecida com os conhecimentos oferecidos pela neurociência contemporânea dedicada, direta ou indiretamente, a esse assunto - desde que interpretados criticamente, e não aceitos indiscriminadamente -, tratar-se-á a seguir dos estudos acerca do funcionamento do cérebro que se inserem na temática ora abordada.

\subsubsection{Aportes da neurociência à questão do autocontrole}

O conceito de autocontrole na formação da vontade tem ocupado ao longo da história não somente os filósofos, mas também os cientistas que estudam o comportamento, uma vez que a capacidade de exercer tal capacidade parece fundamental para o bem-estar e o sucesso humanos. Nesse âmbito, se revela importante, desde logo, indicar que a abordagem neurocientífica da investigação acerca dos mecanismos de tomada de decisão repousa sobre três princípios, premissas base de qualquer estudo nessa linha: (a) os processos mentais - inclusive o autocontrole - não são entes abstratos, mas decorrem dos processos cerebrais; (b) as afirmações a respeito de processos mentais não devem contradizer o conhecimento operacional do cérebro; e (c) o estudo da dinâmica do funcionamento do cérebro permite que se aprenda sobre os processos mentais - dentre os quais o livre-arbítrio (WALTER, 2009, p. XI). Partindo desses pressupostos, a neurociência do comportamento tem buscado, por meio de experimentos com mapeamento da atividade cerebral, identificar as estruturas e os mecanismos neuronais ativados nos momentos de deliberação e de escolha - nos quais o autocontrole atua - e, a partir disso, sugerir como funciona o processo de tomada de decisão no cérebro humano.

Nesse contexto, algumas pesquisas tem obtido destaque na literatura científica, como a realizada pelos neuroeconomistas Todd A. HARE, Colin F. CAMERER e Antonio RANGEL (2009, pp. 646 a 648), descrita no artigo "Self-control in decision-making involves modulation of the vmPFC valuation system" (ou "Autocontrole na tomada de decisão envolve modulação do sistema de avaliação do córtex pré-frontal ventromedial (vmPFC)"), publicado na revista Science. Em síntese, observou-se nessa investigação, a partir da utilização de imagens de ressonância magnética funcional (fMRI) - técnica que mede a atividade cerebral por meio da detecção de mudanças no fluxo sanguíneo associadas à ativação neuronal -, as quais registraram o funcionamento do cérebro de pessoas em dieta envolvidas em decisões reais sobre consumo de alimentos, que a 
atividade no córtex pré-frontal dorsolateral (DLPFC) aumentava quando os indivíduos exerciam autocontrole, em correspondência com a atividade no córtex pré-frontal ventromedial (vmPFC).

Inicialmente, o escopo do experimento era investigar quais processos neuronais seriam os responsáveis pelo acionamento do autocontrole e como tais processos interagiriam com os circuitos de avaliação e de tomada de decisão do cérebro. Diante desse propósito, os pesquisadores partiram de duas hipóteses: $(i)$ as decisões orientadas por objetivos ("goal directed decisions") têm suas bases em um sinal de valor codificado no córtex pré-frontal ventromedial (vmPFC); e (ii) o autocontrole envolve modulação, pelo córtex pré-frontal dorsolateral (DLPFC), dos sinais de valor computados no córtex préfrontal ventromedial (vmPFC). Para testar suas hipóteses, recrutaram pessoas que declararam estar em dieta e utilizaram imageamento por ressonância magnética funcional (fMRI) para monitorar e estudar a atividade neuronal nas áreas cerebrais mencionadas (vmPFC e DLPFC) nos momentos em que os participantes tomavam decisões reais a respeito de quais alimentos ingerir.

Os testes realizados por meio do método empregado - minuciosamente reportados no artigo -, produziram resultados que proporcionaram, na compreensão dos autores, percepções sobre duas questões abertas na neurociência do comportamento. Em primeiro lugar, as conclusões atingidas sugeririam que os problemas relacionados ao autocontrole surgem em situações nas quais diferentes fatores (por exemplo, medidas de saúde e de gosto) devem estar integrados no córtex pré-frontal ventromedial (vmPFC) para calcular valores de objetivos; além disso, sugeririam também que a atividade do córtex pré-frontal dorsolateral (DLPFC) é necessária para que fatores de ordem maior, como a saúde, sejam incorporados no sinal de valor daquela área cerebral (vmPFC). Os pesquisadores especulam que o córtex pré-frontal ventromedial (vmPFC) evoluiu, originalmente, para prever o valor de curto prazo dos estímulos e que os humanos desenvolveram a habilidade de incorporar considerações de longo prazo em valores por meio da atribuição, a certas estruturas, como o córtex pré-frontal dorsolateral (DLPFC), da habilidade de modular o sinal básico de valor. Em segundo lugar, no que diz respeito a outra questão aberta sobre a qual a pesquisa aportaria nova visão, inferiu-se que uma diferença fundamental entre sucesso e falha do autocontrole seria a medida em que o córtex pré-frontal dorsolateral (DLPFC) pode modular o córtex pré-frontal ventromedial (vmPFC). Na análise dos neurocientistas, variações individuais na habilidade do córtex pré-frontal dorsolateral 
(DLPFC) em modular o córtex pré-frontal ventromedial (vmPFC) podem ocorrer em razão de diferenças, de pessoa para pessoa, na constituição daquela área cerebral ou de sua conectividade com outras partes do cérebro.

Ainda de acordo com os resultados do experimento, as áreas do córtex pré-frontal dorsolateral (DLPFC) que desempenham um papel no autocontrole seriam similares às áreas que operam no controle cognitivo e na regulação emocional. Essa conclusão seria consistente com formulações anteriores a respeito da função do córtex pré-frontal dorsolateral (DLPFC) no controle cognitivo, segundo as quais essa parte do cérebro envia sinais a outras regiões cerebrais para promover o "processamento relevante para a tarefa" ("task-relevant processing") e suprimir atividades irrelevantes. Com base nisso, os pesquisadores informaram acreditar que as descobertas obtidas podem ser o começo de uma explicação de por que a inteligência, o controle cognitivo e a regulação emocional estão relacionados com várias medidas comportamentais do autocontrole.

Ademais, os autores do estudo apontaram que os resultados de sua pesquisa, proporcionando uma melhor compreensão da neurobiologia do autocontrole na tomada de decisão, podem ter repercussão em diversos campos do conhecimento, tais como: a medicina, no âmbito de problemas como o vício e a obesidade; a economia, na área da análise de políticas públicas relacionadas à saúde e à poupança; e o direito, no que se refere aos critérios que devem ser utilizados para determinar se um indivíduo está em pleno comando de suas faculdades de tomada de decisão.

O grande mérito, ao menos no atual estágio de desenvolvimento científico, das pesquisas de neurociência do comportamento voltadas à identificação e explicação dos mecanismos de operação do autocontrole no processo de tomada de decisão é a constatação de que o exercício dessa aptidão fica prejudicado quando há comprometimento das áreas e dos sistemas cerebrais a ela relacionados. Essa intrincada relação entre neurofisiologia e comportamento associados ao autocontrole pode ser observada em diversas patologias, notadamente as que provocam degeneração dos lobos frontal e temporal, como, por exemplo, o mal de Alzheimer e, especialmente, a demência frontotemporal.

Em pesquisa realizada pelos neurocientistas Mario F. Mendez, Andrew K. CHEN, Jill S. SHAPIRA e Bruce L. MiLler (2005, pp. 99 a 104), constatou-se que pacientes com perda de tecido encefálico deixaram de ter a capacidade de controlar os impulsos ocultos 
no inconsciente, passando a realizar as mais diversas violações de normas sociais, desde comer restos de comida encontrados em lixeiras públicas, cantar em momentos inapropriados e tirar a roupa diante de pessoas estranhas, a, até mesmo, furtar objetos em lojas (sem qualquer tentativa de dissimulação do ato), frequentemente ostentando comportamentos fisicamente agressivos ou sexualmente transgressores. Verificou-se no estudo que essa irremediável degeneração da área do cérebro relacionada ao autocontrole gera comportamento socialmente desajustado em cerca de cinquenta e sete por cento dos pacientes com demência frontotemporal, e em aproximadamente sete por cento dos pacientes acometidos pelo mal de Alzheimer.

Outro de exemplo de alteração no cérebro que leva a modificações no comportamento pode ser notado no caso do tratamento da doença de Parkinson. Em investigação conduzida pelos médicos M. Leann DodD, Kevin J. KLOS, James H. Bower, Yonas E. GEDA, Keith A. JosePhS e J. Eric AhLSKOG (2005, pp. 1.377 a 1.381), observouse que parte dos pacientes diagnosticados com mal de Parkinson, ao ingerir uma substância denominada pramipexol para o tratamento da doença, passou a fazer apostas de maneira absolutamente descontrolada, tornando-se jogadores patológicos. Alguns deles, além disso, começaram a ter compulsão por comida e por bebidas alcoólicas, assim como a apresentar sinais de hipersexualidade. A pesquisa culminou por revelar que tais comportamentos foram originados de uma desarmonia nos níveis de um neurotransmissor ${ }^{50}$, a dopamina.

De maneira detalhada, tem-se o seguinte: o mal de Parkinson - um distúrbio degenerativo que tem por sintomas o tremor das mãos, o enrijecimento de pernas e braços e a perda do equilíbrio corporal - resulta da perda de células cerebrais que produzem a dopamina, de maneira que, para tratar a doença, é necessário aumentar os níveis desse neurotransmissor no paciente - elevando a produção de tal substância no corpo ou usando medicamentos que se ligam diretamente a seus receptores. Ocorre que a dopamina possui duplo papel no cérebro, atuando no comando motor, mas também operando como principal mensageiro nos sistemas de recompensa, isto é, orientando o ser humano no que diz respeito às satisfações úteis à sobrevivência, como a alimentação, a hidratação, a reprodução sexual etc.

Segundo a pesquisa, devido ao papel da dopamina no sistema de recompensa, seu desequilíbrio pode incitar a prática de novos comportamentos, antes contidos pelos

\footnotetext{
${ }^{50}$ Substância de baixo peso molecular sintetizada pelo neurônio, armazenada em vesículas e liberada para o espaço extracelular com a função de transmitir informação entre um neurônio e outra célula (LENT, 2010, p. $70)$.
} 
mecanismos de autocontrole (como apostar e usar drogas), ou a um exagero nos comportamentos já desempenhados (comer e copular, por exemplo). A alteração no sistema de recompensa, nesse caso, se revela reversível, bastando que seja reduzida a dosagem do medicamento para que cessem - ou sejam controladas - tais compulsões. Todavia, resta claro, a partir dos resultados da investigação, que uma leve alteração no equilíbrio da química do cérebro pode causar severas mudanças no comportamento, o que reforça a compreensão de que a conduta do ser humano não é formada à parte de sua constituição biofisiológica.

No âmbito da aplicação do direito penal, o impacto dessa verificação - vale dizer, de que a tomada de decisão se altera quando há mudança na neurofisiologia do cérebro - é direto, pois repercute incisivamente no espectro da imputabilidade. Expressamente: uma vez prejudicada a aptidão ao autocontrole, resta ausente a capacidade de autodeterminação e a possibilidade de o agente agir de outro modo, o que o torna, portanto, inimputável, isto é, inapto a ser responsabilizado penalmente.

Por outro lado, quando o mecanismo cerebral de tomada de decisão se encontra em condições perfeitas, a neurociência (ainda?) é incapaz de verificar se é operado por leis determinísticas ou a partir de uma iniciativa livre. Em outras palavras, as pesquisas neurocientíficas não lograram (por ora?) atestar se o processo de tomada de decisão humana funciona por meio de cadeias causais livres ou pré-determinadas, permanecendo aberto e inconclusivo o debate em torno do livre-arbítrio.

As pesquisas de neurociência do comportamento, ao menos até o presente momento, não oferecem conclusões definitivas acerca da existência (ou não) de liberdade de vontade na tomada de decisão pelo ser humano. Assim, diante da vasta complexidade do campo de estudo e do pouco conhecimento que se logrou construir a respeito do funcionamento do cérebro humano, a interpretação dos resultados dos estudos na área requerem cautela, também por conta do impacto que descobertas nessa seara podem causar em outros campos do saber, assim como na realidade social. Essa questão, por sua posição nuclear na discussão travada no presente capítulo, será retomada na sequência do trabalho, precisamente no item "4.4. A contribuição da neurociência ao problema do livrearbítrio: uma mudança de paradigma?".

\subsubsection{Críticas ao fundamento do autocontrole}


A capacidade do homem de ultrapassar, interromper e, de um modo geral, alterar os impulsos reativos de seu organismo constitui uma das mais dramáticas e impressionantes funções da individualidade humana, com amplas implicações em uma larga gama de padrões de comportamento (CARver; SCHEIER, 1981; Wegner; PenNebaKer, 1993), tais como a prática criminosa (GOTTFREDSON; HIRSCHI, 1990), o fumo (RUSSELL, 1971) e o regime alimentar (HERMAN; POLIVY, 1975).

De um modo geral, a literatura científica tem indicado uma relação intrincada entre a capacidade de autocontrole e o sucesso nos mais diversos aspectos da vida. Nesse sentido, há, por exemplo, pesquisas que identificam homens com autocontrole bem desenvolvido como mais propensos a ter relações conjugais estáveis (e menos tendentes a se divorciar) (KELLY; CONLEY, 1987); e que reconhecem crianças que lidam melhor com o adiamento de gratificação como mais calmas, mais concentradas, mais resistentes à frustração e com desempenho escolar acima da média (FUNDER; BLOCK, 1989; FUNDER; BLOCK; BLOCK, 1983).

De outro turno, a incapacidade ou a falha no autocontrole têm sido associadas a uma série de repercussões pessoais e sociais negativas (BAUMEISTER et al., 1994), como a depressão (WENZLAFF et al., 1988), a agressividade (BAUMEISTER, 1997) e o pensamento taciturno ou obsessivo (MARTIN; TESSER, 1989). Nessa mesma linha, estudos de psicologia comportamental têm concluído que muitos dos problemas que atingem tanto os indivíduos, em particular, como a sociedade, como um todo - do vício a comportamentos sexuais sem proteção, passando pelo baixo rendimento escolar - derivam de um fracasso na autorregulação (BAUMEISTER et al., 1994).

Contudo, a despeito da fundamental função do autocontrole no comportamento humano, de sua contundente influência na tomada de decisão, demonstrada pelas literaturas médica e psicológica, uma questão permanece aberta: seria a capacidade (ou a incapacidade) de autocontrole suficiente para determinar se faremos escolhas boas ou ruins, se teremos comportamentos socialmente ajustados ou transgressores? Em outras palavras, existem limitações ao papel do autocontrole no âmbito da tomada de decisão, ainda que tal aptidão se encontre em perfeitas condições neurofisiológicas?

As críticas à compreensão do autocontrole enquanto fundamento do livre-arbítrio partem exatamente dos questionamentos acima colocados, orientando-se no sentido de que não basta ao ser humano ter capacidade de autocontrole para que tome decisões com 
liberdade de vontade. De um lado, porque essa capacidade de autocontrole seria limitada, de um modo semelhante à oferta restrita de força ou de energia em um indivíduo (MURAVEN et al., 1998, p. 774). De outro, uma vez que nem mesmo um autocontrole ideal - não importa o quão frequente e bem-sucedido seja seu exercício - garantiria autonomia de vontade, a qual dependeria, também, de que os princípios e os valores apreendidos pelo sujeito, os quais orientam o exercício daquela competência, não fossem oriundos de processos de "lavagem cerebral" ou de "controle da mente" (MELE, 2002, p. 533).

Com relação à primeira crítica, nasce de um estudo realizado pelos psicólogos Mark Muraven, Dianne M. Tice e Roy F. BAumeister (1998, pp. 774 a 789), cuja proposta foi a de examinar a razão pela qual o exercício do autocontrole pode falhar em pessoas que possuem essa aptidão em condições ideais. Os pesquisadores partiram da hipótese de que a capacidade de autocontrole seria limitada em cada indivíduo - de um modo semelhante a sua oferta de força ou de energia, que é restrita -, de maneira que quando uma pessoa se engajasse em uma situação de autorregulação, deveria demonstrar subsequentes decréscimos dessa competência em outras tarefas que requeressem seu desempenho. O argumento, aqui, é de que o exercício do autocontrole, enquanto domínio e superação dos impulsos, implica esforço e empenho por parte do sujeito, notadamente em razão da forte estimulação fisiológica (como o aumento da pressão arterial, a aceleração de batimentos cardíacos etc.) provocada em situações como essa.

A partir de quatro diferentes experimentos, a investigação buscou analisar de que forma um ato de autocontrole afeta o seguinte. Segundo reportado pelos autores, os resultados demonstraram que os esforços em autorregulação são frequentemente seguidos de decréscimos temporários dessa mesma competência em outras esferas, não relacionadas à primeira. Para os pesquisadores, esse padrão sugere, confirmando a hipótese de que partiu o estudo, que a capacidade de autocontrole é um recurso limitado, assim como o são a força e a energia, de modo que usá-lo significaria perdê-lo, ainda que transitoriamente, em razão do esforço despendido.

Considerando que o sucesso nas diferentes esferas da vida depende do autocontrole, sua concepção enquanto um recurso limitado traria ao menos duas implicações de ordem prática. Primeiramente, a de que não é recomendável engajar-se simultaneamente em vários comportamentos que demandem autocontrole (como mudar de hábitos, resistir a tentações, terminar tarefas complicadas etc.), mostrando-se mais adequado, se possível, a 
elaboração de um planejamento que organize, de maneira programada, a execução de tais atividades, para que aquele recurso se encontre sempre renovado. Nessa mesma linha, segundamente, a de que se revela razoável prever que quando as circunstâncias da vida apresentarem demandas extras dos recursos autorregulatórios (o nascimento de um filho ou a necessidade de se adaptar a novas conjunturas, por exemplo), o autocontrole tenderá a falhar em esferas que antes se encontravam perfeitamente equilibradas (v. g., o controle emocional, a alimentação, o consumo de drogas etc.), tornando mais compreensíveis escolhas antes absolutamente censuráveis. Diante desse quadro, sustenta-se no artigo que a judiciosa gestão, por cada indivíduo, de sua capacidade de autocontrole parece ser mais conducente ao sucesso, à saúde e à felicidade a longo prazo.

De uma perspectiva distinta, a segunda crítica ancora-se na noção de que a autonomia de vontade não depende somente de uma perfeita capacidade de autocontrole do ponto de vista mental/cerebral -, mas de que as preferências e os valores do sujeito, que orientam o exercício daquela aptidão, tenham sido moldados por si próprio. Essa ideia, formulada pelo filósofo Alfred MELE (2002, pp. 529 a 548), parte da definição, por Gerald DWORKIN (1988, p. 108), de que a autonomia é a capacidade de segunda-ordem para refletir criticamente sobre as preferências e os desejos de primeira-ordem, aliada à habilidade de se identificar com esses ou de alterá-los à luz de preferências e de valores de ordem superior. Segundo MELE, a capacidade e a habilidade referidas por DwORKIN, apesar de realmente presentes na constituição do ser humano, compõem, em verdade, a ideia de autocontrole, e não de autonomia de vontade - noções próximas, mas diferentes, em sua visão. Para aquele autor, conquanto o autocontrole seja indispensável para a autonomia da vontade, o primeiro termo não é equivalente ao segundo, o qual representaria uma ideia mais ampla.

$\mathrm{O}$ argumento de que o conceito de autocontrole é insuficiente para fundamentar a compreensão de autonomia de vontade origina-se do seguinte raciocínio, apresentado por MELE: se, como parece, todo processo de reflexão crítica é regulado ou guiado por princípios e valores já estabelecidos, alguns deles serão pressupostos ou tidos como certos em cada processo; ocorre, todavia, que se tais princípios ou valores dados como certos 
forem produto de "lavagem cerebral" ou outras formas de "controle da mente" ${ }^{51}$, tal processo ficará maculado.

A ideia por trás do argumento é a de que um indivíduo com autocontrole em condições perfeitas pode vir a ser controlado por um agente externo, isto é, por um manipulador - o que anularia sua autonomia de vontade. Pormenorizadamente explicando, tem-se que embora esse hipotético sujeito efetivamente possa vir a executar sua potente capacidade de dominar a motivação que vai contra seus melhores julgamentos sobre ações, convicções, valores etc., se a base sobre a qual repousam tais julgamentos puder ser atribuída a um manipulador ("mind-controler"), sua vontade não será livre - mas controlada por esse agente externo -, culminando em ausência de autonomia. Em outras palavras, por meio do controle de quais princípios e valores um individuo tem como certos, alguém pode fazer com que a capacidade crítica e reflexiva daquela pessoa sirva a seus próprios propósitos - propósitos esses aos quais, possivelmente, tal indivíduo era frontalmente contrário anteriormente à manipulação.

De acordo com Mele, para que o autocontrole se converta em autonomia de vontade, deve ser complementado por outra característica, denominada "história causal", consistente em como os indivíduos se tornaram o que são, como adquiriram os valores e as aspirações que guiam sua autorreflexão, sua tomada de decisão etc. Nessa linha, a "história causal" de um sujeito deve ser formada a partir de propósitos autênticos, no sentido de naturais ao próprio indivíduo - o que não significa que a autonomia de vontade implique que uma pessoa seja inteiramente autoconstituída. Ao reverso, sustenta o autor, qualquer concepção de autenticidade que exija que as pessoas possuam a característica de serem, elas mesmas, a fonte de seus princípios, preferências, etc., não se revelaria adequada, uma vez que são consideráveis as influências externas na formação de nossos valores. Na concepção do filósofo, o que confere autenticidade aos propósitos de um sujeito formando sua "história causal" e compondo, ao lado do autocontrole, a autonomia de vontade - é a ideia de responsabilidade por seus valores, suas preferências, seus princípios etc., vale dizer, a noção de que o próprio indivíduo é o responsável pela formação de seu caráter.

MELE busca deixar clara a importância da "história causal" do sujeito no âmbito de sua autonomia - e, consequentemente, a insuficiência da capacidade de autocontrole enquanto fundamento da liberdade de vontade - a partir de um exemplo fictício, que utiliza

\footnotetext{
${ }^{51}$ Tais como o sugestionamento hipnótico, a manipulação, a persuasão coerciva, a influência subliminar etc., realizados de maneira não ad hoc (DWORKIN,1988, p. 18).
} 
para ilustrar sua formulação. Nesse caso hipotético, há dois sujeitos, Bob e Alan, que acabam de realizar enormes sacrifícios por amor aos seus filhos; a despeito dessa atual identidade de contexto, enquanto Alan tornou-se, por si próprio, um pai extraordinariamente amoroso, o entusiasmo de Bob para com seu filho e a identificação com seus novos valores parentais são produtos de uma secreta "lavagem cerebral" conduzida na noite anterior; previamente ao procedimento, Bob tinha demonstrado apenas um moderado interesse no bem-estar de seu filho, o que levou um futurístico juizado da infância e da juventude a pensar que seria melhor para todos os envolvidos se Bob fosse como Alan. Conforme esclarece o professor da Flórida, apesar de a postura de ambos os pais fictícios ter se tornado idêntica, o comportamento de Bob é considerado menos autônomo que o de Alan. Diante dos conceitos apresentados, isso se deve à possibilidade de encarar Alan como o responsável por seu caráter - ainda que a constituição desse derive, em grande medida, de determinantes externos -, ao passo que o mesmo não se aplica a Bob, que não somente teve seus comportamentos causados por fatores exteriores a si, mas também - e aqui reside o traço diferenciador de sua situação - foi impelido a tanto, a partir da intervenção em sua índole e em seu temperamento por meio de manipulação cerebral.

WELZEL (1956, pp. 161 e 162), ao colocar a possibilidade de liberação da coação causal dos impulsos por meio do autocontrole como fundamento do "poder agir de modo diverso" e, portanto, da culpabilidade finalista, não atentou para as limitações de tal aptidão. E, conforme as críticas acima expostas, parece ser um erro justificar a existência de liberdade de vontade exclusivamente na capacidade de autocontrole. Se, de um lado, a teoria welzeliana da culpabilidade apresenta resposta satisfatória às situações em que desajustes cerebrais prejudicam a capacidade de autocontrole, lavando o sujeito à prática de injustos penais, uma vez que o agente é isentado de responsabilidade penal em virtude de sua inimputabilidade, o mesmo não se aplica, de outro lado, aos casos em que aquela aptidão se encontra em perfeitas condições. Em tais hipóteses, considera-se, pelo menos a princípio, que o sujeito tem plena liberdade para deliberar e decidir, estando, portanto, apto à punição.

Mas será que age livremente um sujeito que transgride a lei penal em uma conjuntura na qual seguidamente teve que exercer seu autocontrole ${ }^{52}$, considerando-se, na

\footnotetext{
${ }^{52}$ Por exemplo, o agente agride um desafeto, provocando-lhe lesões corporais, certo dia no período da noite, tendo sido demitido de seu emprego e abandonado pela esposa na mesma data pela manhã, mas resistido
} 
linha de pesquisas científicas em psicologia do comportamento, que se trata de um recurso limitado, cujo uso contínuo gera seguidos decréscimos da competência no desempenho de futuras tarefas? E mais: na esteira da crítica filosófica apresentada, é possível afirmar que tem autonomia de vontade um indivíduo que deixa aflorar seus impulsos violentos e pratica um injusto penal, mas cujos valores e princípios que orientam seu autocontrole não são lhe autênticos, e sim fruto de manipulação mental ${ }^{53}$ ? São perguntas para as quais ainda não há uma resposta definitiva.

4.2.2. Experiência subjetiva de possibilidade de eleição de condutas: SCHÜNEMANN

Conforme exposto no item "3.5.3.1. SCHÜNEMANN e a concepção indeterminista da culpabilidade em um Direito como realidade socialmente criada", a culpabilidade em SCHÜNEMANN (2009, pp. 469 a 474) é compreendida como a reprovabilidade pelo fato, fundamentada na possibilidade de o agente ter atuado de outra maneira, em conformidade com o Direito. Tal concepção supõe, evidentemente, a liberdade para agir de modo diverso e, portanto, a liberdade de vontade, pois, como o próprio autor argumenta, careceria de sentido realizar uma censura jurídica ou moral em face de um acontecimento determinado pelas leis causais, que viria a se desenvolver necessariamente. De acordo com o penalista alemão, essa formulação é coerente com o direito penal atual, que encontraria a liberdade de vontade como uma parte previamente dada da realidade social constituída pela linguagem, a qual, em sua compreensão, não pode ser ignorada. Segundo sua visão, essa liberdade de vontade - na qual se fundamenta a responsabilização penal - não se trata de mera ficção, mas de verdadeiro aspecto da realidade social, tão real quanto essa própria - e, desde uma perspectiva ontológica, de um produto da evolução, vale dizer, do desenvolvimento da consciência humana.

Pormenorizando seu raciocínio, SCHÜNEMANN explica que a realidade social é constituída por meio do sentido subjetivo, que se manifesta em toda ação concernente à

\footnotetext{
bravamente no período da tarde a reencontrar seus antigos colegas de carteado no bar onde se encontravam, não cedendo às tentações do jogo e do álcool, vícios que houvera anteriormente superado.

${ }^{53}$ Como a seguinte situação hipotética: um bebê recém-nascido é entregue ao líder de um regime totalitário, que o envia a uma escola militar destinada à formação de órfãos de acordo com os preceitos nacionalistas, imperialistas, antiliberais e antidemocráticos daquela ditadura; posteriormente, já crescido, esse sujeito, trabalhando a serviço do governo que durante vinte anos investiu intensamente em sua formação moral e na construção de seu temperamento, vem a agredir um opositor, provocando-lhe lesões corporais, no contexto da repressão a manifestações de protesto contra o poder estabelecido.
} 
sociedade e, de uma maneira especialmente clara, na comunicação linguística. Nesse âmbito, a socialização é concebida como a progressiva integração do indivíduo na totalidade dos valores sociais, a qual encontra na linguagem tanto seu conteúdo mais relevante, como seu instrumento fundamental. Assim sendo, a concepção dos membros de uma sociedade a respeito da realidade - isto é, suas ideias acerca dessa - constituiria os próprios elementos dessa realidade social.

$\mathrm{Na}$ concepção do doutrinador, dentre os elementos que formam a realidade social está a experiência subjetiva de liberdade de vontade, por se tratar de ideia permanentemente reproduzida pelos indivíduos no contato com os outros membros da sociedade, sendo reciprocamente atribuída. Consoante essa compreensão, a liberdade de vontade aparece pressuposta na realidade social tanto na explicação de nossas próprias ações frente aos outros, como na perspectiva inversa, vale dizer, na nossa interpretação das ações praticadas pelos demais indivíduos - e, assim, nos respectivos juízos de valor que realizamos. Paralelamente a isso, também o Direito apareceria como um produto cultural e, destarte, como parte da realidade socialmente criada, apoiando-se, por consequência, de uma maneira imutável, sobre os pressupostos elementares da interação social tal como essa tenha sido constituída na respectiva sociedade.

Para SCHÜNEMANN, em síntese, a experiência subjetiva é evidência suficiente para a fundamentação indeterminista, calcada no livre-arbítrio, da responsabilidade penal, uma vez que daquela deriva o reconhecimento recíproco da liberdade de vontade, o qual seria parte indiscutível da realidade social, pertencente, inclusive, aos pressupostos básicos, indispensáveis, das relações sociais reguladas pelo Direito.

A despeito da coerência dessa tese, algumas questões restam inexplicadas: no rol de percepções subjetivas do ser humano, não estão inclusas aquelas fruto de ilusão, de confusão dos sentidos? Considerando que o livre-arbítrio é fenômeno ainda não demonstrado e comprovado cientificamente, bastaria a impressão subjetiva de que temos essa capacidade para tomar como real sua existência e, em consequência, nela fundamentar a responsabilidade penal? Para um exame adequado da viabilidade da tese da experiência subjetiva de liberdade de vontade enquanto fundamento da culpabilidade, se revela necessário estudar se tal percepção pode vir a se tratar de uma mera ilusão dos sentidos, tarefa que a neurociência do comportamento tem se incumbido há algumas décadas. 


\subsubsection{Aportes da neurociência à questão da experiência subjetiva}

A questão da experiência subjetiva direta de liberdade de vontade é de especial interesse para os neurocientistas porque vai de encontro ao que a ciência, em seu atual estágio de desenvolvimento, conhece a respeito do funcionamento do cérebro. Se, por um lado, nossa percepção é a de que temos livre-arbítrio para agir, por outro, nenhum estudo foi capaz, ao menos até o momento, de demonstrar onde, em nossa maquinaria cerebral, tal fenômeno atuaria.

Como explica o neurocientista David EAGLEMAN (2012, p. 179), pelo conhecimento que a neurociência logrou construir até o momento, toda atividade cerebral parece ser impelida por outra atividade no cérebro, em uma rede amplamente complexa e interligada, o que deixaria espaço para nada além de atividade neuronal, não havendo intervalo para o que chama de um "fantasma na máquina". Isso significa que para ter algum efeito nos atos do corpo, o livre-arbítrio precisaria influenciar a atividade cerebral contínua, estando fisicamente conectado a pelo menos alguns neurônios. Ocorre, segundo o pesquisador, que jamais se encontrou algum ponto do cérebro que não fosse impulsionado por outras partes da rede, mas justamente o contrário: ao que se verificou, cada área desse órgão é densamente interconectada com as outras partes - e impelida por elas -, sugerindo que nenhuma porção é independente das demais e, portanto, "livre". Assim, de acordo com o autor, na presente fase de desenvolvimento científico, não é possível encontrar um hiato físico onde encaixar o livre-arbítrio - o "causador sem causa" -, vez que parece não haver sequer uma parte do cérebro que não siga uma relação causal com as demais. Em outras palavras, pelos conhecimentos atuais em neurociência, não se pode compreender como uma entidade não física (o livre-arbítrio) interagiria com uma entidade física (a matéria do cérebro).

Visando solucionar esse dilema, isto é, investigar porque temos a impressão de que agimos com liberdade de vontade, se a compreensão de como funciona nosso sistema nervoso central sugere não haver qualquer intervalo físico onde inserir tal ente, algumas pesquisas em neurociência foram desenvolvidas, com a pretensão de se testar diretamente o livre-arbítrio. Dessas, duas obtiveram maior destaque na literatura científica.

A primeira, e mais impactante delas, diz respeito a um experimento realizado na década de 1980 pelo neuropsicólogo Benjamin LIBET (1999, pp. 47 a 57), da Universidade da Califórnia em São Francisco, que, basicamente, consistia em colocar eletrodos na 
cabeça dos participantes e solicitar-lhes que realizassem uma tarefa extremamente simples: levantar um dedo no momento de sua própria escolha e, diante de um cronômetro de alta precisão, anotar o instante exato em que "sentiram o impulso" de fazer o movimento. Realizado o procedimento, os resultados revelaram que as pessoas se tornavam conscientes do impulso para se mexer cerca de um quarto de segundo antes de realmente porem em ação o movimento. E o mais surpreendente: por meio do exame dos registros de Eletroencefalograma (EEG) - equipamento que grava graficamente as correntes elétricas desenvolvidas no encéfalo - se descobriu que a atividade em algumas partes específicas do cérebro começou a aumentar antes mesmo de os participantes sentirem o impulso para se moverem. E não só um pouco antes, mas mais de um segundo, o que levou os pesquisadores a concluir de que certas áreas do cérebro tomavam decisões bem antes de a pessoa viver conscientemente o impulso.

No ano de 2007, outra pesquisa ganhou destaque na comunidade científica. Trata-se do experimento coordenado pelo neurocientista John-Dylan HAYNES, do Bernstein Center foi Computational Neuroscience, de Berlim, em que os participantes foram colocados dentro de um equipamento de escaneamento do cérebro, no qual uma tela exibia por alguns instantes uma sucessão de letras aleatórias, e solicitados a apertar um botão com qualquer dos dedos indicadores - esquerdo ou direito - no momento em que sentissem o impulso para tanto, devendo, ainda, lembrar a letra que estava sendo exibida na tela quando fossem tomadas as decisões. O teste utilizou o imageamento de ressonância magnética funcional (fMRI) para revelar a atividade cerebral em tempo real, assim que os voluntários escolhessem usar uma de suas mãos - esquerda ou direita. E os resultados, mais uma vez, se revelaram inesperados para os pesquisadores: a decisão consciente de apertar o botão era feita cerca de um segundo antes do ato, mas um padrão de atividade cerebral sugeriria que a opção era escolhida por volta de sete segundos antes - ou seja, com muita antecedência em relação às pessoas sequer estarem conscientes de realizar a escolha, seu cérebro parecia já haver decidido (SOON et al., 2008; SMITH, 2011).

Em ambos os experimentos, os resultados sugeriram que a efetiva tomada de decisão - materializada em uma série de coalizões neurais - seria realizada nos "bastidores" do cérebro, de maneira inconsciente, chegando à mente consciente apenas momentos antes da realização do ato, em tempo suficiente para nos dar a impressão de que o processo foi levado a efeito de maneira livre. Mas essa conclusão necessariamente implicaria no sepultamento da ideia do livre-arbítrio? E mais: haveria outras interpretações possíveis a 
partir dos resultados empíricos dos testes, que conduzissem a desfechos diferentes no que tange à compreensão de que somos os causadores de nossas ações?

O próprio LIBET (1999, pp. 51 a 53), diante da possibilidade suscitada por seu experimento - isto é, de que a tomada de decisão ocorreria de forma inconsciente -, argumentou que isso não significa ausência completa de liberdade de vontade, propondo que essa permaneceria na forma de poder de veto. Detalhadamente, sua compreensão é a de que, embora não possamos controlar o fato de que temos o impulso para realizar a ação, há uma janela (mínima) de tempo para evitá-la. Todavia, como argumenta David EAGLEMAN (2012, p. 180), apesar da impressão (subjetiva direta) de que o veto é livremente escolhido, não há elementos científicos que sugiram que ele também não seria resultado de atividade neural desenvolvida nos "bastidores", oculta da visão consciente. Além disso, a ideia de poder de veto, tal qual apresentada por LIBET, é muito próxima à de autocontrole, aptidão que parece apresentar diversas limitações, como já abordado alhures, no item "4.2.1.2. Críticas ao fundamento do autocontrole".

De uma perspectiva diversa, há também o argumento de que o experimento liderado por LIBET não representa ameaça ao livre-arbítrio, uma vez que os resultados empíricos $^{54}$ obtidos pelo teste não levariam, necessariamente, à conclusão atingida por seus autores $^{55}$. Seguindo essa linha, a filósofa Adina Roskies (2011, pp. 10 e 11) argui, preliminarmente, que todos os processos neuronais tomam tempo; e que, além disso, partese, na neurociência do comportamento, da assunção de que todos os processos mentais são (ou são resultado de) processos cerebrais, os quais são causados por processos cerebrais anteriores. Levando isso em consideração, assere que não é surpreendente - mas, pelo contrário, esperado - que atividades cerebrais precedam atividades mentais, assim como qualquer comportamento. $\mathrm{Na}$ visão da autora, não causa surpresa que hajam sinais neuronais de eventos que são preditivos de comportamentos - como o movimento dos dedos -, da mesma forma que não causará estranheza se também forem encontrados sinais

\footnotetext{
${ }^{54}$ Especificamente: (i) quando os participantes são instruídos a reportar o momento de sua consciente intenção de agir (W), associando-a a um ponto em movimento na face de um relógio, o momento da intenção (W) geralmente precede o movimento em aproximadamente $200 \mathrm{~ms}$ (LIBET, 1999, pp. 49 a 51); e (ii) nas situações em que os participantes do teste são instruídos a realizar uma ação simples (como movimentar um dedo), um potencial evocado medido na superfície do escalpo - ou seja, um potencial de prontidão ("readiness potential", ou RP) - precede o movimento em aproximadamente $550 \mathrm{~ms}$, se não houver planejamento da ação (RP tipo II), ou em cerca de 1000 ms, na hipótese de tal ação ter sido pré-programada (RP tipo I) (LIBET, 1999, pp. 49 a 51).

55 Qual seja: a de que sinais neurais da intenção de iniciar uma ação são evidentes muito antes de nos tornarmos conscientes de nossa vontade de agir, de maneira que as intenções conscientes ocorrem somente depois de as ações já haverem iniciado, o que faz com que não sejamos a causa de nossas ações (LIBET, 1999, pp. 53 e 54$)$.
} 
neuronais preditivos de experiências subjetivas de vontade - e esperar que assim não fosse significaria, em suas palavras, recusar o fisicalismo ${ }^{56}$.

Para a professora de Dartmouth, o fato de LIBET considerar surpreendente que exista um sinal neuronal que se manifesta antes da consciência da intenção desfigura a perspectiva dualista ${ }^{57}$ da experiência consciente. Em seu entendimento, a real questão sobre o assunto, concernente à interpretação dos resultados dos experimentos capitaneados por LIBET, é se o pesquisador está certo ao conectar causalmente os potenciais de prontidão ("readiness potentials", ou RPs) a movimentos motores iminentes, ao invés de a intenções de movimento. Nesse sentido, ROSKIES questiona a compreensão do neurocientista de que os RPs constituiriam sinais de subsequente ação motora - ou de inicialização inconsciente da atividade motora ${ }^{58}$. Em seu entendimento, os dados fornecidos pelo teste poderiam levar a outras interpretações válidas, como a de que o potencial de prontidão (RP) reflete processos envolvidos na formação da intenção consciente de agir, e não na construção do movimento - entendimento que preservaria o papel da vontade (e, portanto, o livre-arbítrio) na tomada de decisão.

À parte outras críticas ao método empregado por LIBET em seu experimento, ROSKIES fundamenta na pressuposição, por parte daquele, de correlação entre o potencial de prontidão (RP) e a inicialização do movimento, a fragilidade da conclusão de que a tomada decisão seria realizada, em grande parte, no inconsciente humano. E, por conta dessa debilidade, defende a autora que a pesquisa do professor de São Francisco não deve ser encarada como uma ameaça à ideia do livre-arbítrio.

No campo do direito penal, essa mesma crítica é levantada por Mercedes PÉREZ MANZANO (2013, pp. 118 a 120). Tomando por referência experimentos realizados por Judy Trevena e Jeff Miller (2010, pp. 447 a 456) - que, em uma variação do teste realizado por LIBET $^{59}$, observaram haver detecção de potencial de prontidão (RP) mesmo

${ }^{56}$ Doutrina segundo a qual a linguagem da física é, por direito, a linguagem de toda a ciência, tanto das
ciências denominadas morais, como das ciências da natureza (LALANDE, 1993, p. 419).
${ }^{57}$ Na filosofia da mente, o dualismo é a teoria segundo a qual o mental e o físico - ou a mente e o corpo; ou a
mente e o cérebro - são, de alguma maneira, tipos radicalmente diferentes de coisa. Está inserida no contexto
do problema mente-corpo, consistente no questionamento acerca de qual é a relação entre as propriedades
mentais (como a consciência - incluindo experiências perceptivas e emocionais, etc. - e a intencionalidade -
incluindo crenças, desejos, etc.) e as propriedades físicas (como tamanho, peso, forma, cor, movimento pelo
tempo e espaço etc.) (RoBINSON, 2012). A perspectiva dualista da experiência consciente considera que ao
menos alguns aspectos da consciência se encontram fora do reino físico (VAN GuLICK, 2014).
${ }_{58}$ LIBET assume que o potencial de prontidão (RP), registrado por meio de Eletroencefalograma, é
causalmente conectado à atividade motora, de maneira que a geração daquele levaria necessariamente à
realização dessa - exceto se fosse barrada pelo "poder de veto" do indivíduo.
${ }^{59}$ O experimento TREVENA e MILLER (2010, pp. 447 a 456) foi inspirado naquele realizado por LIBET, mas
estruturado com variações: em uma delas, os participantes deveriam tomar a decisão de se pressionariam - ou 
quando o participante decide não efetuar qualquer movimento -, a penalista espanhola sustenta que a atividade cerebral evidenciada pelo RP parece representar um processo neuronal inespecífico, associado à implicação do participante na tarefa que foi designado a realizar, provavelmente ligado à manutenção da atenção e ao dispêndio de esforço requeridos para executá-la. Tendo isso em vista, a autora refuta a interpretação LIBET acerca dos resultados de seu experimento, rejeitando sua conclusão de que a tomada de decisão se dá de forma inconsciente - ainda que com a possibilidade consciente de autocontrole.

Diante do quadro acima desenhado, observa-se que, a despeito de trazer novas perspectivas à discussão a respeito da experiência subjetiva direta enquanto argumento pró livre-arbítrio, a neurociência (ainda) não foi capaz de apresentar uma resposta definitiva à questão de se nossa percepção de que tomamos decisões com liberdade de vontade é algo real ou fruto de ilusão dos sentidos.

\subsubsection{Críticas ao fundamento da experiência subjetiva}

As críticas à fundamentação do livre-arbítrio na experiência subjetiva direta partem da corrente doutrinária para a qual a vontade consciente se trata de mera ilusão. Expoente dessa linha de pensamento, Daniel Wegner (2004, pp. 649 a 660) formula a teoria da causação mental aparente ("apparent mental causation"), segundo a qual quando um pensamento surge na consciência imediatamente antes de uma ação, é compatível com tal ação e inconsistente com causas alternativas dessa ação, o ser humano experiencia a vontade consciente e atribui a si próprio a autoria daquela ação.

De acordo com WEGNER, a experiência da vontade consciente nada mais é do que a percepção que temos de que fazemos as coisas. Essa percepção, aplicando-se a várias das coisas que fazemos, nos transmite, seguidamente, a sensação de que nós conscientemente causamos nossas ações. Ocorre, segundo o autor, que essa percepção não é uma leitura correta do que ocorre na mente e no cérebro humanos enquanto nossas ações são produzidas. Em verdade, a experiência de vontade consciente surgiria a partir de processos

não - a tecla, enquanto que em outra sempre deveriam pressioná-la; em uma terceira variação, os voluntários apertavam o botão com o dedo da mão indicada pelos pesquisadores, ao passo que em outra eles próprios decidiam qual mão utilizariam; e por fim, havia a variação em que os sujeitos deveriam tomar a decisão antes de escutarem um sinal sonoro, e outra em que a decisão deveria ser tomada depois do som. 
em que a mente interpreta a si própria - e não de processos em que a mente dá causa à ação. Explicando de outra forma, a vontade consciente, conforme a teoria do professor de Harvard, constituiria uma indicação de que pensamos que causamos uma ação, e não a revelação da sequência causal por meio da qual a ação foi produzida.

$\mathrm{O}$ argumento central dessa tese é o seguinte: como os mecanismos da tomada de decisão são altamente complexos - envolvendo uma extensiva e ainda pouco conhecida gama de sistemas cerebrais - e regem-se por uma cadeia causal oculta em nosso inconsciente, ao realizamos nossos comportamentos conscientemente buscamos uma explicação do porquê de termos agido da maneira como agimos. Nesse sentido, como as verdadeiras razões pelas quais agimos da forma como agimos não nos estão acessíveis, buscamos um modo conferir sentido à realização de nossas ações, e o fazemos atribuindoas a nossa "vontade".

A ilusão da vontade consciente, segundo o pesquisador, é produzida da mesma maneira que as demais ilusões, tais como as provocadas por mágicos e ilusionistas. Valendo-se dessa analogia, haveria a sequência causal real dos fatos - isto é, o conjunto de eventos que o mágico orquestra nos bastidores - e a sequência causal percebida dos fatos vale dizer, o conjunto de eventos que parecem ter acontecido. A última (sequência causal percebida) é a responsável pelo truque, isto é, pela aparência de que as leis da natureza são quebradas - como quando, por exemplo, pessoas são "partidas ao meio" (e depois "reunidas", novamente) e animais e coisas surgem "do nada". A primeira (a sequência causal real), por sua vez, é geralmente mais complicada - ou inesperada - que a ilusão, mas devido ao treinamento do mágico e ao uso de equipamentos especiais (trajes com bolsos ocultos, caixas com fundos falsos etc.), passa despercebida do público.

Consoante a tese de WEGNER, no que concerne ao comportamento humano, a sequência causal real dos fatos envolve um conjunto massivo de complicados mecanismos, de maneira que cada uma das ações humanas constitui a culminação de uma intrincada série de processos mentais/cerebrais, a qual não nos está acessível. Assim, para conferir racionalidade a nossos comportamentos, nossa mente busca uma interpretação mais fácil (e aparentemente plausível) a respeito, criando a impressão de que as ações são frutos de nossa vontade - e de que, portanto, fomos os responsáveis pela tomada de decisão. Em outras palavras, nossa mente consciente criaria a contínua ilusão de que somos a causa de nossas ações, por não saber do que, realmente, elas derivam. De acordo com o neuropsicólogo, nossa mente tem um mecanismo de autoexplicação que produz uma 
sensação mais ou menos continuada de que está na consciência a causa de nossas ações ou seja, na vontade -, ao passo que, em verdade, ela não tem a capacidade compreender a si própria de maneira suficientemente satisfatória para poder dizer quais são as reais causas de nossas ações.

No mesmo sentido da formulação de WEGNER, o neurocientista Michael GAZZANIGA (2011, pp. 75 a 103) sustenta que o ser humano criou a ilusão de um "self"60 e, com isso, a sensação de que somos os causadores nossas ações e de que, portanto, livremente decidimos a respeito delas. Para esse autor, a forte impressão subjetiva de que vivemos uma experiência unificada - a despeito de o cérebro operar simultaneamente uma série de sistemas especializados amplamente distribuídos - se deve ao fato de possuirmos o "módulo intérprete" ("the interpreter module"), isto é, uma parte do cérebro, integrada dinamicamente aos demais mecanismos neuronais, responsável por gerar explicações acerca de nossas percepções, memórias e ações, e das relações entre elas.

Segundo o professor de Santa Barbara, no complexo cerebral diferentes sistemas competem por atenção, emergindo apenas o vencedor, que subjaz-se à experiência consciente daquele momento. Nesse sentido, a consciência flui de modo tranquilo e natural de um momento a outro, como uma narrativa única, unificada e coerente, em razão daquele sistema especializado ("módulo intérprete"), que confere sentido à experiência consciente, a qual é moldada em tempo real, enquanto nosso cérebro reage a constantes mudanças de estímulos externos, calcula potenciais cursos de ação e executa as devidas respostas. Esse processo - conduzido pelo "módulo intérprete" - levaria à construção de uma narrativa pessoal, isto é, de uma história que une a completude dos aspectos distintos da experiência consciente humana em um todo coerente, trazendo ordem ao caos.

GAZZANIGA explica que a natureza construtiva da nossa consciência não é perceptível para nós, de maneira que a ação do "módulo intérprete" só se mostra observável quando o sistema pode ser enganado, levado a cometer erros óbvios, como notadamente ocorre em pacientes com lesões encefálicas ou com o cérebro dividido - isto é, sem ligação entre os dois hemisférios cerebrais. A partir do estudo de indivíduos com

\footnotetext{
${ }^{60}$ Conceitualmente, a noção de "self" é definida como a representação daquilo que sabemos sobre nós mesmos. Esse conhecimento a nosso respeito pode se apresentar de quatro maneiras diferentes: (a) como um conceito que compreende um conjunto difuso de "eus" de contextos específicos; (b) como um conjunto de narrativas que abordam nosso passado, presente e futuro; (c) como uma imagem, ou uma representação baseada em percepções que contém nossa face, corpo e modos de expressão não verbal (gestos); e (d) como uma rede associativa que contém informações acerca de nossos traços de personalidade, memórias autobiográficas, pensamentos e comportamentos, separadas com base em autoconhecimento episódico e semântico (TURK; GAZZANIGA et al., 2003, pp. 65 e 66).
} 
essa condição, descobriu-se que mesmo quando o hemisfério esquerdo perde toda a consciência acerca dos processos mentais geridos pelo hemisfério direito, e vice-versa, o paciente não nota que falta a um lado do cérebro o outro - como se não tivesse consciência daquilo ao que não mais tem acesso.

Nossa percepção subjetiva, na compreensão do neurocientista, nasce da busca incessante de nosso cérebro em tornar inteligíveis os pedaços de informação que surgem em nossa consciência. Segundo o autor, trata-se de um processo de racionalização post hoc, em que o intérprete incumbido de construir nossa história o faz apenas a partir daquilo que chega à consciência. Considerando que os processos mentais conscientes são lentos, em comparação com os inconscientes, aquilo que emerge, na verdade, já transcorreu.

$\mathrm{Na}$ concepção do pesquisador, o "módulo intérprete" se trata de algo exclusivamente humano, localizado no hemisfério esquerdo de nosso cérebro, e sua pulsão de gerar hipóteses seria o gatilho para as crenças humanas, as quais, por sua vez, compeliriam nossos cérebros. Apesar de conferir uma perspectiva ilusória a um aspecto fundamental experiência humana, esse módulo teria, por razões ainda não bem compreendidas, relevante papel no curso da evolução. Resultado de seleção natural, de alguma maneira permitiu que os indivíduos que o possuem tomassem decisões que resultaram em sobrevivência e reprodução, possibilitando a perpetuação da espécie humana.

Na seara do direito penal, a fundamentação da liberdade de vontade na experiência subjetiva direta, defendida por SCHÜNEMANN - e compartilhada também por HIRSCH (2007, pp. 28 e 29) - é diretamente criticada por alguns doutrinadores. Nesse sentido, Eduardo DEMETRIO CRESPO (2013 [1], pp. 25 e 26) refuta o entendimento segundo o qual nossa autopercepção como seres livres significa que efetivamente somos livres, pare efeitos de atribuição de responsabilidade penal. Sustenta o autor, amparado em trabalho do fisiologista Francisco J. RuBIA (2013, p. 189), que uma coisa é assumir a experiência de vontade consciente, e outra, muito diferente, a causação das ações por tal vontade consciente, já que, por vezes, nossas impressões subjetivas se revelam falsas, como a impressão subjetiva de que o sol se move ao redor da terra - que permaneceu como certeza para o ser humano durante vinte séculos -, razão pela qual a percepção subjetiva se mostra insuficiente para a heteroimputação jurídica. 
Partilhando desse entendimento, Bernardo FEIJOO SÁnCHEZ (2013, pp. 282 a 287) afirma que esse tipo de fundamentação - baseada em experiências ou sentimentos subjetivos - não corresponde ao funcionamento de nosso sistema jurídico. Argumenta, nesse sentido, ser evidente que para o ordenamento vigente a declaração de culpabilidade é independente de percepções subjetivas do acusado, de maneira que se pune o culpável ainda que ele não tenha a sensação de liberdade de vontade, do mesmo modo que se considera inculpável - em razão da inimputabilidade - o esquizofrênico que tem uma visão delirante da realidade, a despeito de atuar absolutamente convencido de sua liberdade. $\mathrm{Na}$ concepção do penalista, a experiência subjetiva de liberdade pode até ser válida para processos puramente morais de autoimputação ou autorreprovação, próprios das teorias subjetivas da retribuição, mas não para os de atribuição de responsabilidade realizados por terceiros ou pelo sistema social, como é o caso do processo judicial. De acordo com o autor, para efeitos jurídico-penais a perspectiva de primeira pessoa não deve ser determinante, e sim a perspectiva válida na interação social, uma vez que a pena não é um fenômeno puramente pessoal, mas uma instituição social. Nessa linha, a perspectiva interpessoal da ordem jurídica não pode estar ancorada em dados incompatíveis com os conhecimentos científicos imperantes, de maneira que, se o que diz a ciência como observadora de segunda ordem se encontra em contradição com a percepção do sujeito que é objeto de imputação, somente pode valer o que aquela estabelece - no caso, que o cérebro gera histórias plausíveis, apesar de eventualmente falsas, para garantir a sobrevivência (e atribuir sentido) ao organismo que o sustenta, ainda que isso acarrete ao indivíduo percepções ilusórias acerca da realidade (RUBIA, 2013, p. 189).

SCHÜNEMANN (1991 [2], pp. 152 a 158; 2002 [1], pp. 24 a 48; 2002 [2], pp. 112 a 114; 2009, pp. 469 a 474), ao sustentar a manutenção do "poder agir de modo diverso" enquanto conteúdo da culpabilidade, sob o fundamento de que o livre-arbítrio é algo verdadeiro, por fazer parte da realidade social, em razão da concessão recíproca de liberdade de vontade entre os indivíduos, fruto de sua experiência subjetiva direta, deixa de abordar a questão - apresentada com ênfase pela neurociência, e discutida também por penalistas - das falsas percepções, isto é, da possibilidade de nossas impressões, eventualmente, basearem-se em ilusões. Assim, as críticas dirigidas ao argumento da experiência subjetiva do livre-arbítrio - sobre o qual, no fundo, repousa sua concepção acerca da culpabilidade -, no sentido de que se trata (ou pode se tratar) de percepção 
ilusória, provocada pelo próprio cérebro humano, acabaram por não ser contestadas pelo doutrinador.

Consoante o teor dessas críticas, acima pormenorizadas, e considerando a ausência de contestação por parte do autor, parece frágil, de fato, afirmar a existência de liberdade de vontade com base em nossa experiência subjetiva direta, nela fundando a responsabilidade penal. A autoconsciência, ou a sensação de um "self" que controla todos os processos mentais, é, certamente, um requisito para que se cuide de culpabilidade - ao menos do ponto de vista da imputabilidade -, mas se revela insuficiente como meio de fundamentar tal elemento do delito enquanto fenômeno social e jurídico. Se, por um lado, o livre-arbítrio é fenômeno ainda não demonstrado e comprovado empiricamente, por outro, a compreensão neurocientífica de que a impressão de liberdade de vontade parece se tratar, de um modo geral - assim como efetivamente se trata, em casos específicos -, de percepção ilusória, já é razão suficiente para inviabilizar a tese da experiência subjetiva direta de liberdade como fundamento do "poder agir de modo diverso".

\subsection{Fundamentos filosóficos e científicos do pensamento penal não baseado na afirmação do livre-arbítrio}

4.3.1. Indemonstrabilidade empírica do livre-arbítrio: ROXIN, KINDHÄUSER e outros

O problema da indemonstrabilidade empírica do livre-arbítrio é, em grande medida, responsável pela crise do conceito normativo de culpabilidade, conforme apresentado no capítulo "3.4. A crise do conceito de culpabilidade normativa". Em linhas gerais, o argumento por trás da crítica dirigida àquela concepção é o de que não seria possível comprovar com métodos científicos que o autor, no momento do fato, poderia haver atuado de modo distinto ao efetivamente realizado, razão pela qual o "poder agir de modo diverso" - fundamento largamente assentado na ideia de liberdade de vontade - não poderia figurar como conteúdo material da reprovabilidade.

Conforme bem retratado por Tomás S. ViVES ANTón (2010, p. 49), a dúvida acerca da existência do livre-arbítrio, decorrente da impossibilidade de se demonstrá-lo, fez nascer o seguinte dilema na doutrina penal: ou se renuncia à ideia do "poder agir de modo diverso" como conteúdo material da culpabilidade - e, portanto, como fundamento da pena, 
ficando-se, assim, sem base para contestar que o sistema penal trate o ser humano como um mero objeto; ou se adere a tal ideia, com a consequente admissão de que o Estado pune seus cidadãos com lastro em um fundamento inseguro, indemonstrável e, portanto, inaceitável - isto é, sem fundamento algum.

A despeito de praticamente unânime no reconhecimento da origem do problema da insustentabilidade do "poder agir de modo diverso" como fundamento da culpabilidade isto é, a indemonstrabilidade do livre-arbítrio -, o pensamento jurídico-penal ficou dividido no que diz respeito à sua resolução. Com algumas adaptações às alternativas de caminho apresentadas por VIVES ANTÓN, a doutrina penal pró superação da concepção welzeliana da culpabilidade repartiu-se em dois grupos opostos: (i) o dos autores que, apesar de não afirmarem a existência do livre-arbítrio, mantêm-no na estrutura da culpabilidade, porque entendem se tratar de presunção necessária para o direito penal, por considerarem que de outra forma a culpabilidade não se sustentaria enquanto elemento do delito - e sua exclusão da estrutura de responsabilização criminal seria deletéria, em razão das garantias ao indivíduo que sua concepção aportou ao exercício do jus puniendi estatal - assim, por exemplo, ROXIN, KINDHÄUSER e ZAFFARONI; e (ii) o dos autores que buscam se afastar da problemática do livre-arbítrio estruturando modelos de culpabilidade baseados em outros fundamentos - nesse sentido, v. g., JAKOBS, HASSEMER e MuÑOZ CONDE.

A crise do conceito finalista de culpabilidade - causada, principalmente, pela inviabilidade de comprovação empírica da liberdade de vontade do ser humano -, tem como marco inicial a publicação, por Karl ENGISCH, em 1963, do livro "Die Lehre von der Willensfreiheit in der strafrechtsphilosophischen" (ou "A teoria da liberdade de vontade na atual doutrina filosófica do direito penal"), obra em que foram sistematizadas as críticas àquela formulação. Todavia, passados mais de cinquenta anos da deflagração da crise, ainda persistem ainda as razões que a ensejaram? Em outras palavras, com a tecnologia adquirida nas últimas cinco décadas, com o vertiginoso desenvolvimento das pesquisas em neurociência, ainda se mostra impossível comprovar empiricamente a (in)existência do livre-arbítrio?

4.3.1.1. Aportes da neurociência à questão da indemonstrabilidade empírica 
Conforme já abordado no item "4.2.2.1. Aportes da neurociência à questão da experiência subjetiva", Benjamin LIBET e John-Dylan HAYNES, dentre outros neurocientistas, pretenderam, por meio de experimentos realizados com técnicas de leitura da atividade cerebral, testar diretamente o livre-arbítrio, vale dizer, verificar de que maneira operam os processos de tomada de decisão no cérebro humano. Como se discutiu naquele capítulo, a despeito de a publicação das pesquisas ter levado muitos autores a concluir que a liberdade de vontade não existe, ao menos do modo como usualmente a compreendemos - porque, ao que se constatou, as decisões seriam tomadas de forma inconsciente pelo cérebro, e só então levadas à mente consciente -, a interpretação que esses pesquisadores deram aos resultados empíricos observados foi intensamente criticada por uma parcela da comunidade científica, de maneira que ainda não há consenso a respeito de se tais estudos representam - ou não - a efetiva demonstração empírica da inexistência do livre-arbítrio.

Por outro lado, como retratado no capítulo "4.2.1.1. Aportes da neurociência à questão do autocontrole", o que a neurociência logrou constatar, por meio de pesquisas voltadas ao estudo dos mecanismos de tomada de decisão, é que esse processo fica prejudicado quando há comprometimento das áreas e dos sistemas cerebrais a ela relacionados, com repercussão direta no âmbito da aplicação do direito penal, impactando decisivamente no espectro da imputabilidade. Isso porque, como se explicou, uma vez prejudicada a faculdade de tomar decisões, resta ausente a capacidade de autodeterminação e a possibilidade de o agente agir de outro modo, tornando, portanto, inimputável o autor do injusto penal.

Levando em consideração as duas conclusões parciais acima relatadas, e tomando como premissa os três princípios básicos da neurociência do comportamento ${ }^{61}$, no que diz respeito à (in)demonstrabilidade do livre-arbítrio, importante corrente de neurocientistas sustenta tratar-se de questão não relevante para o direito penal. Para esses pesquisadores, não se mostra necessário comprovar cientificamente a existência de liberdade de vontade do ser humano para que se promova a responsabilização penal, uma vez que a atividade criminosa seria prova suficiente de anormalidade cerebral, de maneira que os autores de

\footnotetext{
${ }^{61}$ Vale lembrar: (a) os processos mentais não são entes abstratos, mas decorrem dos processos cerebrais; (b) as afirmações a respeito de processos mentais não devem contradizer o conhecimento operacional do cérebro; e (c) o estudo da dinâmica do funcionamento do cérebro permite que se aprenda sobre os processos mentais (WALTER, 2009, p. XI).
} 
injustos penais deveriam ser sempre tratados como incapazes de ter agido de outra maneira.

Partindo da concepção de que os processos mentais decorrem dos processos cerebrais e de que, portanto, o comportamento de um indivíduo não está divorciado de sua neurofisiologia, esses neurocientistas argumentam que qualquer comportamento anormal dentre os quais, o criminoso - é causado por problemas na função cerebral, tais como mutações genéticas, desequilíbrios hormonais ou nos níveis de neurotransmissores, além de tumores e acidentes vasculares. Nesse sentido, conforme sustenta Wolf SINGER (2004), ainda que não se consiga medir o que há de errado no cérebro autor de um crime, poder-seia pressupor, com boa segurança, que há ali uma anormalidade, uma vez que os atos daquele sujeito seriam prova suficiente da existência uma disfunção cerebral, mesmo que (ainda) não se conheça os detalhes a respeito.

Explicando de outro modo, David EAGLEMAN (2012, pp. 187 a 190) argui que o avanço da tecnologia e da medicina ampliou largamente, no último século, o espectro da inimputabilidade, permitindo a descoberta de uma ampla gama de disfunções cerebrais que, antigamente, permaneciam não identificadas, levando à punição pessoas que, na verdade, eram inimputáveis. Sustenta esse neurocientista, considerando a perspectiva retratada, que, no modelo atual de responsabilização penal, o espectro da inimputabilidade continuará sempre aumentando, à medida que, com o progresso científico e tecnológico, melhorar a medição de problemas cerebrais. Com novas técnicas e novos instrumentos, condições cerebrais que atualmente são ocultas se abririam ao exame, permitindo a descoberta da explicação biológica subjacente a alguns tipos de comportamentos socialmente desajustados - como já ocorreu, em tempos passados, com os relacionados à esquizofrenia, à epilepsia e à depressão. Se no presente só é possível detectar apenas grandes tumores cerebrais, a neurociência projeta daqui a cem anos poder identificar padrões relacionados com problemas de comportamento em níveis inimaginavelmente menores de microcircuitos, propiciando melhores explicações acerca de predisposições a certas ações - e, eventualmente, possibilitando seu tratamento.

A perspectiva apresentada pelos neurocientistas SINGER e EAGLEMAN - segundo a qual a prática criminosa seria indício da existência de uma anormalidade cerebral, de maneira que o autor de um injusto penal deveria ser encarado sempre como incapaz de agir de outro modo -, se aceita pelo pensamento penal, implicaria a necessidade de uma guinada no modelo de responsabilização criminal, possivelmente no sentido de um afastamento da 
noção de reprovação e de uma aproximação às ideias de prevenção. Esse assunto, por sua complexidade, será analisado em capítulo específico, topograficamente localizado na terceira parte do trabalho, especificamente no item "5.2. A hipótese da transgressão penal enquanto indício de anormalidade cerebral: discussões acerca da posição da imputabilidade na estrutura de imputação e da intervenção cerebral como resposta estatal ao delito".

\subsubsection{Críticas ao fundamento da indemonstrabilidade empírica}

A discussão em torno da indemonstrabilidade científica do livre-arbítrio, para alguns pesquisadores, não tem tanta importância quanto aparenta, pois independentemente dessa questão empírica, a crença na liberdade teria valor por si própria, do que decorreria a necessidade de nela se ancorar o sistema social. A compreensão acerca do valor ínsito da liberdade de vontade representa a convicção de que as pessoas - e a sociedade, em geral se comportam melhor quando acreditam que tem livre-arbítrio.

Esse ponto de vista é sustentado por algumas pesquisas de psicologia experimental, como a desenvolvida por Kathleen D. VOHS e Jonathan W. SCHOOLER (2008, pp. 49 a 54). Buscando analisar se as pessoas desempenham melhores ações quando creem ter liberdade de vontade, os psicólogos montaram o seguinte experimento: os participantes, todos estudantes universitários, foram divididos em dois grupos; ao primeiro grupo foi dada uma passagem do livro "The astonishing hypothesis" (ou "A hipótese espantosa"), do biólogo Francis CRICK, de viés determinista, para que fosse lida antes da submissão a um teste computadorizado; em seguida, foi-lhes dito que havia uma falha no programa de computador responsável pelo questionário, de maneira que a resposta a cada pergunta apareceria automaticamente em uma janela; além disso, foi-lhes instruído que, para prevenir que isso acontecesse, deveriam, em cada questão, pressionar um dos botões do teclado - de modo que um esforço extra era requerido dos voluntários para que não trapaceassem; no que se refere ao segundo grupo, o experimento era idêntico, salvo pelo conteúdo excerto, que nesse caso se referia à passagem de um livro de teor inspirador, com uma visão positiva da vida.

Os autores observaram que, em geral, os estudantes que leram o fragmento sobre determinismo trapacearam, ao contrário dos que leram o texto sobre atitudes positivas. Disso concluíram que, em essência, um estado mental afetou o outro, sugerindo que a 
descrença no livre-arbítrio produz um sutil sinal ao cérebro de que exercer esforço para conter maus impulsos é inútil, concedendo-lhe, assim, permissão para manter-se inerte, isto é, não se importar. E não se importar parece ser a tendência natural do ser humano, vez que a atitude oposta requer empenho e implica em dispêndio de energia (cf. GAILlIOT et al., 2007, pp. 325 a 336).

Nesse mesmo sentido, outra investigação, essa conduzida pelos psicólogos Roy F. Baumeister, E. J. MASiCAMPo e C. Nathan DeWALl (2009, pp. 260 a 268), revelou que a leitura de excertos de teor pró-determinista elevava a tendência, por parte dos voluntários do estudo, a agirem agressivamente e a serem menos prestativos com os outros. Com base nessa observação, os pesquisadores sugeriram que a crença no livre-arbítrio pode ser crucial para motivar as pessoas a controlarem seus impulsos a ações egoístas; e, além disso, que uma quantidade significativa de autocontrole e energia mental é requerida para superar os impulsos egoísticos e para conter os impulsos agressivos. O argumento por trás dessa proposição é o de que o estado mental que se apoia na ideia da voluntariedade dos atos tem efeito na subsequente tomada de decisão relacionada à ação. Disso se inferiria, ademais, que não apenas as pessoas têm a impressão de que controlam suas ações, como parece, também, ser bom para todos acreditarem nessa percepção.

No campo do direito penal, a crítica é de outra natureza. Nesse sentido, o argumento da indemonstrabilidade empírica do livre-arbítrio - utilizado por alguns penalistas para rejeitar a concepção finalista da culpabilidade - é refutado por DiegoManuel LUZÓN PEÑa (2013, pp. 380 a 384), para quem tal fundamento não justifica a construção de modelos de responsabilização penal não baseados na liberdade de vontade. Seu raciocínio é o de que, apesar de se criticar as concepções baseadas na liberdade de vontade porque seria essa indemonstrável cientificamente, da mesma maneira haveria indemonstrabilidade empírica do determinismo, isto é, da falta de livre-arbítrio humano.

Com efeito, LUZÓN PEÑA reconhece a indemonstrabilidade empírica da liberdade de vontade de um sujeito em um caso concreto, por considerar ser irrepetível a situação do indivíduo no momento do fato, diante da impossibilidade em se reproduzir características exatamente iguais, em um momento posterior, para comprovar se tal indivíduo reagiria de outra maneira. Contudo, de outro lado, argumenta que também não se revela possível a comprovação experimental do determinismo - vale dizer, de que o sujeito, naquela conjuntura, atuou de maneira automática e necessariamente determinada -, por aquela 
mesma razão, qual seja: não seria possível repetir por inúmeras vezes, como em experimentos de laboratório, exatamente a mesma situação em que a pessoa se encontrava quando praticou o injusto penal, para comprovar se a reação seria sempre a mesma e inferir, disto, que não haveria a possibilidade de agir de outro modo. Assere o autor, além disso, que uma comprovação segura da hipótese determinista deveria se dar não apenas a partir do exame de um (ou alguns) sujeito(s) concreto(s), enquanto grau de amostragem sociológico, mas sim da totalidade dos humanos - o que é impossível.

Para o doutrinador, diante da impossibilidade de demonstração empírica tanto do livre-arbítrio, quanto do determinismo, perde sentido qualquer fundamentação ancorada em algum desses argumentos. Em sua opinião, diante desse dilema, pode-se prescindir de tomar partido, no que diz respeito à culpabilidade, na polêmica indeterminismo/determinismo - sobre a qual, no campo filosófico e teórico-cognoscitivo, cada um tenderia para aquilo que lhe parecesse mais convincente. Isso porque, na sua compreensão, para efeitos de convivência dos homens no seio social - e, portanto, para efeitos de resolução de um problema humano-social como a culpabilidade por um delito -, a sociedade, em geral, e o Direito, em particular, já tomariam partido à favor da existência de liberdade de decisão e de atuação. E, deste modo, seria desnecessária a demonstrabilidade mediante experimentos - ou mediante comprovações físico-químicobiológicas - da liberdade (ou da não liberdade) de todo e cada homem em cada atuação concreta.

É certo que desde a deflagração da crise da concepção normativa da culpabilidade, há mais de cinquenta anos, o desenvolvimento científico e tecnológico logrou nos proporcionar uma compreensão mais apurada do funcionamento do cérebro e de sua relação com os processos mentais. Essa evolução, contudo, não propiciou resposta a todos os questionamentos então levantados pela doutrina penal. Assim, questões como a que diz respeito à demonstrabilidade empírica da liberdade de vontade ainda permanecem abertas, sem soluções seguras ou definitivas, uma vez que, pelo menos até o momento, nenhuma pesquisa, nenhum experimento, foi capaz de comprovar, com método científico, a existência ou a inexistência do livre-arbítrio.

Diante desse quadro, resta ao direito penal avaliar se essa discussão tem (ou deve ter) relevância no que diz respeito à formulação de um modelo de responsabilização penal. Nesse sentido, têm prevalecido, entre os penalistas, posições pró livre-arbítrio, que, apesar 
de afastarem-se da culpabilidade finalista, mantém a liberdade de vontade, de alguma forma, como pressuposto para a punição, seja porque a atribuição recíproca dessa capacidade está intrinsecamente arraigada na sociedade, seja porque a percepção subjetiva de que temos tal aptidão confere responsabilidade a nossas ações - na linha das críticas apresentadas no presente capítulo. Para os autores dessa corrente, portanto, o debate acerca da demonstrabilidade empírica do livre-arbítrio não tem tanta importância quanto aparenta. Em flanco oposto, posicionam-se os teóricos para os quais a ausência de comprovação científica da liberdade de vontade é, efetivamente, um problema, uma lacuna grave da culpabilidade finalista. Por essa razão, buscam estruturar modelos de responsabilização penal alheios ao problema - como faz JAKOBS, ao assentar a punição na motivabilidade normal do agente.

Em nossa compreensão, parece não haver dúvidas de que não é ideal a adoção, pelo Estado, de uma estrutura de imputação lastreada - em maior ou menor medida - em um fundamento cuja existência não é atestada pelas ciências naturais, uma vez que, em última análise, pode-se estar responsabilizando penalmente indivíduos com base em um pressuposto ficcional - falho, por natureza -, e promovendo-se injustiças por conta disso. Todavia, por outro lado, isso não significa que modelos de responsabilidade penal de tal espécie devam ser abandonados. Parece-nos que, no atual estágio da dogmática penal, a análise da adequação dessa formulação à nossa realidade social passa pelo exame acerca da existência (ou não) de alternativas teóricas melhores, quer de um ponto de vista interno (coerência e solidez de seus fundamentos), quer de uma perspectiva externa (compatibilidade com a ordem constitucional e os valores sociais). É exatamente essa verificação comparativa, no que diz respeito à formulação jakobsiana da culpabilidade, que se procederá a seguir.

4.3.2. Comportamento criminoso, normalidade cognitiva e motivação pela norma: JAKOBS

Afastando-se da problemática do livre-arbítrio, JAKOBS (1997, pp. 584 a 586; 2012, pp. 210 a 214; 1992, pp. 1081 a 1083) formula um modelo de responsabilização penal não calcado na ideia de reprovabilidade - mas fundado na manutenção da ordem social - e, portanto, não fundamentado na liberdade de vontade do agente. Na concepção do autor, sendo a culpabilidade a atribuição de responsabilidade em razão da lesão da vigência da 
norma, não faz sentido introduzir o questionamento acerca da existência de livre-arbítrio, pois o único pressuposto desse elemento do delito é que o sujeito possa ser, desde parâmetros cognitivos, motivado pela norma, e nada além disso.

Conforme essa orientação, em que a culpabilidade não é o mesmo que reprovabilidade, mas que consiste na ausência de fidelidade ao ordenamento jurídico - cuja consequência é a pena, concebida com a finalidade de reforçar a validade da norma, assegurando a manutenção da ordem social -, não importa se a vontade do sujeito que praticou o injusto era livre, mas apenas se ela foi formada em condições de normalidade cognitiva. Somente nas hipóteses de erro caracterizado em razão de defeitos cognitivos, a culpabilidade pode ser excluída ou diminuída.

JAKOBS (1992, pp. 1053 a 1055) define o que são os defeitos cognitivos diferenciando-os dos defeitos volitivos. Para chegar a essa especificação, parte da ideia de que as condições psíquicas que devem estar cumpridas para que uma norma seja respeitada, são, de um lado, a motivação para obedecê-la e, de outro, a capacidade mental de reconhecê-la e acatá-la, constituindo-se o comportamento, pois, de uma prestação volitiva (querer) e de uma prestação cognitiva (conhecer e compreender), respectivamente. Enquanto a ocorrência de um defeito volitivo, via de regra, agrava a responsabilidade, essa é exonerada - ou minorada - na hipótese de um defeito cognitivo.

Assim, explica o autor que quanto menor for a vontade do sujeito de respeitar a norma - ou, do ponto de vista inverso, quanto maior e mais obstinada for a infidelidade à norma da atitude do sujeito -, mais grave será sua culpabilidade, a qual será menor, contrariamente, se tal déficit de fidelidade ao direito aparecer com um passo em falso eventual, atípico. Com relação aos aspectos cognitivos do agente, esclarece que quanto maior for a distância que o separar dos conhecimentos necessários - definidos normativamente -, menor será sua culpabilidade, ao passo que essa terá intensidade superior na medida do quanto maior for a possibilidade de superar o desconhecimento.

Por fim, defende o doutrinador ser certo que a culpabilidade está relacionada com a liberdade, mas não com a liberdade de vontade, com o livre-arbítrio, e sim, tão somente, com o que denomina de liberdade de autoadministração própria, ligada à possibilidade de o sujeito agir sem a presença de obstáculos juridicamente relevantes para seus atos de organização.

4.3.2.1. Aportes da neurociência à questão da motivação normal do agente 
A concepção jakobsiana da culpabilidade está assentada na motivabilidade normal do agente, isto é, na normalidade cognitiva do indivíduo, que permite que suas ações sejam motivadas pelos preceitos normativos - evitando, assim, o comportamento criminoso. Desta feita, a responsabilização penal é afastada ou minorada, por conta da ausência ou da diminuição da culpabilidade, em razão de defeitos cognitivos que impeçam ou prejudiquem o indivíduo no que diz respeito ao conhecimento e à compreensão da norma. A ideia, aqui, é de que apenas em condições psíquicas normais reconhece-se o comando normativo, possibilitando o surgimento da motivação para obedecê-lo.

Desde logo, percebe-se dois grandes problema dessa formulação. Em primeiro lugar, o de que o conceito de normalidade cerebral não é algo estanque: considerando que, na medicina, a biologia (o dado químico ou fisiológico) serve de parâmetro para julgar uma diferença como doença (SILVA, 2008, p. 141), todas as novas diferenças descobertas pela ciência em razão da evolução tecnológica produzirão um novo paradigma de cérebro normal (ou saudável). Em segundo lugar, o de que nem sempre é possível, com os conhecimentos atuais, correlacionar a identificação de uma anomalia cerebral com o comprometimento de um estado mental específico (BATTS, 2009, p. 261) - dentre os quais aquele responsável pela capacidade de conhecer e de compreender o teor da norma. Ambos os problemas produzem, por vias distintas, um mesmo efeito, em termos jurídico-penais: a impossibilidade do estabelecimento de um critério seguro de identificação de um cérebro normalmente motivável pela norma - e, portanto, de um indivíduo culpável.

No atual estágio de desenvolvimento da neurociência, os resultados produzidos por suas pesquisas ainda não foram suficientes para fazer cessar tal efeito. Em outras palavras, no momento presente, a neurociência não é capaz de determinar, de modo definitivo, o que é - e o que não é - um cérebro normal, do ponto de vista cognitivo. Isso, por (ainda?) não haver técnicas de diagnóstico biológico - incluindo exames neurocientíficos - que identifiquem se uma pessoa sofre de algum transtorno mental e, se o caso, de qual. Em síntese, não existem biomarcadores confiáveis para qualquer espécie de desordem mental, embora o reconhecimento de tais parâmetros seja o objetivo maior das correntes de pesquisa em saúde mental. Todavia, projetando em alguns anos a evolução da neurociência, é possível traçar alguns potenciais aportes a essa questão, a serem conquistados em um futuro próximo? 
Stephen J. Morse e Willian T. Newsome (2013, pp. 165 a 169) observam, inicialmente, que a neurociência já identificou várias diferenças cerebrais entre indivíduos com transtornos mentais e aqueles com comportamento normal, apesar de nenhuma dessas variações mostrar-se suficientemente elevada - e, portanto, confiável - para que possa ser diagnosticada em casos individuais. Conforme explicam os autores, essa situação ocorre, em parte, em virtude de os critérios de definição daquelas desordens não terem sido, eventualmente, bem validados. Isso significa que não está claro se as categorias usadas pelos profissionais de saúde mental para diagnosticar transtornos refletem, acuradamente, a natureza do funcionamento da doença em termos biofisiológicos. Assim, se essas categorias são, muitas vezes, artificiais (ou ficcionais), não se revelaria surpreendente que a neurociência a elas relacionada muitas vezes não seja precisa em suas diagnoses - o que a leva a ter pouca utilidade para fins de identificação, em casos individuais, de anormalidades cerebrais que impelem o comportamento criminoso, se comparada com os tradicionais testes psicológicos e entrevistas clínicas. A despeito desse quadro atual, contudo, com o refinamento das categorias de diagnóstico e com o processo de sofisticação da neurociência a elas subjacente, é possível prever, com razoável certeza, que ferramentas de diagnose mais precisas se tornarão disponíveis futuramente.

O que é mais difícil antever, segundo esses pesquisadores, é se a neurociência poderá fornecer elementos para o estabelecimento de parâmetros cognitivos ou de controle em exames de inimputabilidade. Isso porque, ainda que o diagnóstico neurocientífico seja certeiro, o comportamento exibido pelas pessoas assim diagnosticadas é extremamente heterogêneo, de maneira que a identificação da anormalidade cerebral, isoladamente, não poderá revelar se aqueles critérios (de inimputabilidade) estavam presentes no caso concreto, sendo necessários outros elementos de informação, dirigidos especificamente à detecção dos problemas cognitivos e de controle.

Pelo menos por enquanto, os exames neurológicos não são capazes de "ler" estados mentais, e ainda não existem marcadores cerebrais para condições como a falta de autocontrole, embora ambas essas áreas sejam objeto de ativa pesquisa experimental. Dessa maneira, de acordo com o penalista e o neurocientista estadunidenses, dados neurocientíficos relacionados a essas questões teriam de ser inferidos a partir dos resultados de outros neurodiagnósticos, com os quais os critérios legais de inimputabilidade poderiam estar associados. Nesse sentido, o mais provável candidato a tal processo seria o aglomerado de habilidades que os neuropsicólogos denominam função 
executiva ("executive function"). Indivíduos com falhas em seu controle executivo aparentam ter problemas em inibir impulsos desfavoráveis de ação, mas não está claro se eles estão associados a defeitos de cognição, tais como a não compreensão do conteúdo da norma penal (impedindo que se saiba o que se deve - e o que não se deve - fazer) e o não entendimento do contex to fático em que se está inserido.

De todo modo, algumas funções neuronais - como a citada inibição de impulsos parecem, seguramente, estar associadas a uma porção específica do cérebro, o córtex préfrontal, que é, certamente, o substrato cerebral de muitas das nossas capacidades racionais, de ordem superior. Assim, mostra-se provável que dados neurais sobre defeitos estruturais ou funcionais do córtex pré-frontal tornem-se relevantes no estabelecimento de critérios cognitivos e de controle. Todavia, MORSE e NEWSOME alertam que se deve ter precaução com tal projeção, já que danos e deficiências cerebrais podem produzir comportamentos completamente opostos, dependendo da específica patologia envolvida. Além disso, ressaltam, é frágil a correlação entre a performance em testes neuropsicológicos de função executiva - tidos, atualmente, como padrão de referência ("gold standard") - e os comportamentos desenvolvidos em situações reais.

De tudo isso, depreende-se que as perspectivas futuras acerca de como a neurociência pode contribuir no estabelecimento de critérios seguros de normalidade cognitiva - especialmente no que se refere às capacidades de compreender a norma e de ser motivado por ela - dependem, primeiramente, de se saber quão específico deve ser nosso conhecimento do funcionamento do cérebro para tanto, vale dizer, em que grau de tal compreensão se tornariam viáveis inferências sólidas a respeito das condutas passadas e atuais dos acusados da prática de injustos penais.

\subsubsection{Críticas ao fundamento da motivação normal do agente}

O fundamento da motivação normal do agente é concebido na doutrina penal para substituir o poder agir de modo diverso enquanto conteúdo material da culpabilidade. Diante da impossibilidade de demonstração empírica do livre-arbítrio, de um modo geral, e da possibilidade de atuação de outro modo, em casos concretos, formulou-se uma alternativa teórica em que a responsabilidade penal subjetiva é fundada na função motivadora da norma penal, isto é, na relação que se estabelece entre o indivíduo e os mandados e proibições ali expressos. A ideia, aqui, é a de que, conquanto não se possa 
atestar, concretamente, a liberdade de vontade de um sujeito, mostrar-se-ia possível identificar quem é e quem não é passível de motivação normativa, a partir de características individuais. Em outras palavras, seria possível identificar quem tem e quem não tem capacidade concreta de se motivar pelo conteúdo da norma. Assim, o elemento fundante da culpabilidade passa a ser não mais a opção que o sujeito faz livremente por violar a norma, mas sim o fato de possuir ele a concreta possibilidade de ser motivado, em sua atuação, pelo comando normativo.

Para os críticos do fundamento da capacidade de motivação normal pela norma, contudo, essa não pode preencher o conteúdo material da culpabilidade, pois apresentaria os mesmos problemas do poder agir de outro modo. Assim, assinala VIVES ANTÓN (2003, pp. 224 e 225) que assentar culpabilidade naquele fundamento, em vez de nesse, não permite, absolutamente, que se escape do dilema da demonstrabilidade, pois a comprovação de se o autor de um injusto penal, na situação concreta em que se encontrava, era suscetível de motivação normal pela norma penal, não apresenta maiores facilidades do que a comprovação de se ele podia ou não ter agido de outro modo. Partindo dessa observação, Paulo BUSATO (2011, pp. 48 e 49) vai além, para afirmar que basear a culpabilidade na possibilidade de atuar de outra maneira, significa, exatamente, o mesmo que ancorá-la na capacidade de motivar-se normativamente.

Na linha da crítica do professor de Valência, PÉREZ MANZANO (1986, pp. 114 a 132 e 140) assere que a possibilidade de demonstrar empiricamente a motivabilidade é tão duvidosa como a possibilidade de demonstrar o poder agir de modo diverso. Segundo a autora, os partidários da teoria da motivação normal do agente solucionam a questão de sua determinação da mesma maneira como o fazem os normativistas, vale dizer, partindo de uma presunção normativa (expressamente, todos os "normais" são motiváveis pela norma e todos os "anormais" não o são), para atribuir - e não, portanto, constatar - a possibilidade de motivação do ser humano normal, recorrendo ao juízo comparativo do homem médio para determinar a culpabilidade - nesse caso por meio do emprego de uma terminologia distinta, qual seja, a normalidade.

Reforçando esse viés crítico ao fundamento da motivação normal do agente, Juan Carlos CARbonell Mateu (1999, pp. 218 a 224) ressalta sua similitude com o poder agir de outro modo. Para o penalista, a afirmação de que um sujeito podia e devia motivar-se pela norma, mas não o fez, tendo assim cometido uma conduta delitiva, equivale a dizer que o sujeito podia e devia levar a efeito uma conduta distinta da que efetivamente 
realizou; ou seja, que tal sujeito era livre para decidir se praticava uma ou outra conduta, sendo essa adequada à norma. Em sua compreensão, portanto, assim como a concepção normativa da culpabilidade, com o conteúdo material da possibilidade de atuação de modo diverso, também a teoria da motivabilidade estaria ancorada na ideia de liberdade da vontade.

A concepção de Busato e CARbonell MAteu difere da análise de ViVES AnTón e PÉREZ MANZANO. Para os primeiros, do que se depreende de sua críticas à motivabilidade normal do agente, esse fundamento repousaria no mesmo alicerce do poder agir de outro modo - isto é, a liberdade de vontade -, sendo ambos, portanto, equivalentes do ponto de vista da sustentação da culpabilidade. Essa compreensão parece equivocada, na medida em que o fundamento da motivação normal do agente independe da existência de livrearbítrio, tratando-se de ideia compatível, inclusive, com o determinismo, uma vez que diz respeito à normalidade dos mecanismos de formação da vontade do sujeito e não à causa dessa - a qual pode ser oriunda, não importa, tanto do próprio indivíduo, quanto de fatores externos a ele.

$\mathrm{Na}$ visão dos dois últimos autores, por outro lado, o poder agir de outro modo e a motivação normal do agente, conquanto diferentes, apresentariam um defeito comum, do que decorreria, em ambos, sua insatisfatoriedade enquanto conteúdo material da culpabilidade: a dificuldade em demonstrá-los empiricamente. Aqui, de fato, a crítica é procedente. Como retratado no item anterior ("4.3.2.1. Aportes da neurociência à questão da motivação normal do agente"), no estágio atual de evolução científica e tecnológica, ainda não é possível estabelecer um paradigma definitivo de cérebro normal (ou saudável) para fins de atribuição de responsabilidade penal, uma vez que o conhecimento que há atualmente acerca do funcionamento sistema nervoso central não permite que se mapeie, com precisão, o processo de formação da vontade em um organismo saudável e se identifique, com segurança, as disfunções que repercutem na motivação da ação pela norma. Isso significa que, ao menos em grande parte dos indivíduos que praticam injustos penais, não é possível comprovar empiricamente se foram (ou não) normalmente motivados pela norma.

Assim, tem-se que a capacidade de motivação normal pela norma se imputa normativamente, de tal maneira que, salvo algumas exceções, é considerada sempre presente. Entretanto, parece haver um problema nessa assunção normativa. Como explica 
Fernando Jorge CóRDOBA (2003, pp. 471 e 472), um "poder" que se imputa normativamente - isto é, que se imputa segundo pontos de vista valorativos - não é senão um "dever". Sua admissão não pressuporia um juízo acerca do ser, mas do dever ser, já que a motivação conforme a norma seria, em verdade, uma prestação que se espera do sujeito, vale dizer, que o sujeito realize. Apesar de a ciência não poder estabelecer se o autor do injusto penal havia podido motivar-se segundo a norma, espera-se que assim ele se porte, determinando-se com base nesse critério, em última análise, sua culpabilidade.

Em face de tudo isso, é possível concluir que a motivação normal do agente pela norma somente será um critério seguro de determinação da culpabilidade se deixar de ser uma assunção normativa - dependente do conhecimento científico da época a respeito do funcionamento do cérebro humano, e de interpretações àquele subjacentes - e passar a apresentar uma abordagem de carga ontológica, o que deve ocorrer quando tivermos uma compreensão mais completa de como opera a formação da vontade no ser humano. Isso, contudo, nem sequer se sabe se um dia irá acontecer.

\subsection{A contribuição da neurociência ao problema do livre-arbítrio: uma mudança de paradigma?}

Nas considerações introdutórias (item "4.1.") do presente capítulo, foi exposto que os debates contemporâneos acerca do livre-arbítrio são orientados não por um, mas por dois questionamentos: o "questionamento determinista" ("A teoria determinista é verdadeira?); e o "questionamento compatibilista" ("O livre-arbítrio é compatível - ou não com o determinismo?). Para que se compreenda qual o real sentido dessas indagações, e quais as repercussões trazidas pela busca de sua solução, é necessário, inicialmente, voltarse ao significado de dois dos conceitos mais importantes no debate filosófico acerca da liberdade de vontade: livre-arbítrio e determinismo.

$\mathrm{Na}$ história filosófica, existem várias teorias distintas acerca da natureza do livrearbítrio, havendo sérias desavenças sobre o que constituiria uma adequada formulação a respeito desse conceito. De um modo geral, no entanto, tradicionalmente o livre-arbítrio é tomado como um tipo de poder ou habilidade de tomar decisões pelas quais se pode ser moralmente responsável ${ }^{62}$. Além disso, são usualmente relacionadas à ideia de livrearbítrio a existência de possibilidades alternativas de escolha de ação - ou o "poder de agir

\footnotetext{
${ }^{62}$ No contexto das discussões em torno do livre-arbítrio, a responsabilidade moral é compreendida como uma espécie de estatuto ligado a decisões e/ou práticas de louvor e culpa moral (FISCHER et al., 2010, pp. 1 e 2).
} 
de outro modo" -, assim como a compreensão de que somos, enquanto indivíduos, a fonte suprema de nossas ações livres - ou a fonte suprema de nossa vontade de realizar ações livres (FISCHER et al., 2010, p. 1). O determinismo, de seu turno, na discussão filosófica em torno do livre-arbítrio, é encarado como a tese segundo a qual em qualquer tempo - pelo menos até o "momento derradeiro" - o universo tem um único e exclusivo futuro fisicamente possível. Em outras palavras, algo é determinístico se tiver somente um resultado fisicamente possível (FISCHER et al., 2010, p. 2).

$\mathrm{O}$ "questionamento determinista" busca solucionar a dúvida de se essa perspectiva de universo é verdadeira. O "questionamento compatibilista", por sua vez, procura desvendar se é possível haver liberdade de vontade em um universo determinista. Há, na filosofia, uma tradição de longa data em se dividir o terreno conceitual à luz das principais respostas ao "questionamento compatibilista". Costumeiramente, os incompatibilistas são aqueles para os quais o livre-arbítrio é incompatível com o fato de o mundo ser determinista, ao passo que os compatibilistas sustentam que liberdade de vontade e universo determinista são noções compatíveis.

É necessário reconhecer que o "questionamento compatibilista" é distinto do questionamento de se há (ou não) livre-arbítrio. Assim, é possível ser um incompatibilista e defender tanto que o livre-arbítrio existe, quanto que não existe. Contudo, conquanto diferentes em seu conteúdo, tais questionamentos - "determinista" e "compatibilista" -, uma vez agrupados em torno do problema filosófico do livre-arbítrio, moldam as quatro principais visões acerca da questão: libertarismo, incompatibilismo duro ("hard incompatibilism"; ou determinismo duro - "hard determinism"), compatibilismo e revisionismo (FISCHER et al., 2010, p. 3). Compreender, ainda que superficialmente, suas características nucleares, permitirá analisar, posteriormente, as contribuições proporcionadas pelas pesquisas de neurociência à discussão envolvendo a liberdade de vontade.

Na literatura filosófica, libertarismo ${ }^{63}$ é a visão de que temos livre-arbítrio e de que o livre-arbítrio é incompatível com o determinismo. O compatibilismo, de sua parte, a despeito de suas variações teóricas, é a corrente doutrinária para a qual o livre-arbítrio existe e é compatível com o determinismo. Contudo, os partidários de uma de suas variações teóricas mais influentes, o semicompatibilismo, apesar de sustentarem que a responsabilidade moral é compatível com o determinismo, são agnósticos em relação a se a

${ }^{63}$ Importante não confundi-lo com o libertarismo político, termo próprio da filosofia política que designa uma de suas correntes teóricas, cujo sentido é absolutamente distinto do aqui tratado. 
compreensão do livre-arbítrio de algum modo pode não ser compatível com o determinismo. Com relação ao incompatibilismo duro, é a perspectiva segundo a qual não temos livre-arbítrio e esse é incompatível com o determinismo. Historicamente, a maioria dos teóricos dessa corrente eram deterministas inflexíveis ("hard determinists"), que sustentavam que não há liberdade de vontade em razão de o universo ser determinista. Contemporaneamente, todavia, são mais comuns as formulações que defendem a inexistência de livre-arbítrio independentemente de se o mundo é determinista ou não, além das construções que afirmam que, a despeito de a liberdade de vontade não ser conceitualmente incompatível com o determinismo, isso não importaria, pois nós simplesmente não a temos. Por fim, há o revisionismo, visão que não se encaixa exatamente na tradicional taxonomia entre compatibilismo e incompatibilismo. A noção nuclear dessa corrente teórica é a de que as figuras do livre-arbítrio e da responsabilidade moral incorporadas pelo senso comum necessitam de revisão, mas não devem ser abandonadas. A despeito de algumas variações pontuais, os revisionistas sustentam que a correta compreensão do livre-arbítrio deve partir do senso comum. Dessa maneira, o revisionismo tem por traço identificador as ideias de que temos livre-arbítrio e de que esse, a partir de uma revisão de nossa autoimagem, é compatível com o determinismo (FISCHER et al., 2010, pp. 3 e 4). As principais características de cada visão a respeito do problema do livre-arbítrio, podem ser resumidas na tabela a seguir.

\begin{tabular}{|c|c|c|c|c|}
\hline & $\begin{array}{l}\text { O pensamento do } \\
\text { senso comum } \\
\text { sobre o livre- } \\
\text { arbítrio e a } \\
\text { responsabilidade } \\
\text { moral são } \\
\text { corretos? }\end{array}$ & $\begin{array}{l}\text { O livre-arbítrio é } \\
\text { compativel com o } \\
\text { determinismo? }\end{array}$ & \begin{tabular}{|l} 
A \\
responsabilidade \\
moral é \\
compatível com o \\
determinismo?
\end{tabular} & $\begin{array}{l}\text { Existe livre- } \\
\text { arbitrio? }\end{array}$ \\
\hline Libertarismo & Sim & Não & Não & Sim \\
\hline Compatibilismo & Sim & $\begin{array}{c}\text { Sim } \\
\text { (para os } \\
\text { semicompatibilistas, } \\
\text { contudo, a resposta } \\
\text { pode ser "Não") }\end{array}$ & Sim & Sim \\
\hline $\begin{array}{c}\text { Incompatibilismo } \\
\text { duro }\end{array}$ & Não & Não & Não & Não \\
\hline Revisionismo & Não & Sim & Sim & Sim \\
\hline
\end{tabular}




\begin{tabular}{|l|l|c|l|c|}
\hline & & $\begin{array}{c}\text { (mas apenas com } \\
\text { uma revisão de } \\
\text { nossa autoimagem) }\end{array}$ & & (ou perto disso o \\
& & & bastante) \\
\hline
\end{tabular}

Tabela 1. Características principais das quatro visões sobre o problema do livre-arbítrio (FISCHER et al., 2010, p. 4).

Conforme acima apresentado, ainda que de modo perfunctório, essas são as quatro mais importantes correntes teóricas em torno da questão do livre-arbítrio, historicamente desenvolvidas no campo da filosofia. Trata-se de visões, muitas delas, moldadas em séculos de reflexão filosófica, coerente com o conhecimento científico disponível à época.

Como se tem observado no presente trabalho, especialmente neste capítulo, o período histórico em que vivemos, especialmente desde os últimos quarenta anos, está marcado, no campo das ciências naturais, pelo vertiginoso desenvolvimento da neurociência, especialmente a neurociência do comportamento. Fruto dessa evolução, uma série de pesquisas tem buscado examinar, a partir do estudo do cérebro humano, os processos de formação da vontade e de tomada de decisão, com impacto direto nas discussões em torno do livre-arbítrio. Nesse âmbito, inclusive, experimentos foram elaborados para testar diretamente a existência de liberdade de vontade - com resultados que suscitaram amplo debate (e polêmica) na comunidade científica.

Diante desse quadro em que, por um lado, a neurociência tem se apresentado como uma área do saber ainda incipiente, apesar de promissora, mas que, por outro, já vem produzindo uma larga quantidade de pesquisas, com resultados muitas vezes inesperados (e controversos), a questão que surge é a seguinte: os aportes da neurociência à questão do livre-arbítrio, provenientes da interpretação dos resultados de suas pesquisas, já têm impactado, de maneira substancial, as compreensões filosóficas em torno do problema? E ainda: se sim, de que maneira? Expressamente: a neurociência solapará a ideia de livrearbítrio?

Como abordado no item "4.2.2.1. Aportes da neurociência à questão da experiência subjetiva", o impacto da neurociência na discussão a respeito do livre-arbítrio se deve, notadamente, aos experimentos realizado por Benjamin LIBET, bem como às pesquisas, na mesma linha, que os sucederam, como aquelas levadas a efeito por JohnDylan HAYNES. Tais estudos, em particular, e o avanço da neurociência, de um modo geral, têm proporcionado uma visão cada vez mais mecanicista acerca de como o cérebro 
gera pensamentos e comportamentos complexos. Essa tendência tem produzido a preocupação, em algumas áreas do conhecimento, de que as futuras contribuições da neurociência levarão as pessoas a abandonarem a crença de que temos liberdade de vontade.

Essa inquietação se origina, notadamente, do fato de que apenas recentemente se tornou factível investigar os fenômenos cognitivos que são traços marcantes da condição humana. Atualmente, há uma difusa e laboriosa comunidade científica dedicada a entender os mecanismos subjacentes àqueles fenômenos. Assim, a preocupação por trás do desenvolvimento neurocientífico é a de que aqueles conhecimentos que antes pareciam eternamente inacessíveis à ciência possam em breve sucumbir a ela: a neurociência nos levaria a enxergar o "universo interior" como apenas parte da máquina regida por leis naturais que é o "universo exterior". Nesse contexto, a percepção que temos de que nossas decisões, escolhas e ações são fruto de nossa vontade livre estaria ameaçada pelo desenvolvimento da ciência, a qual pode revelar a formação do comportamento como física ou mecanicisticamente inteligível - em oposição à nossa experiência subjetiva de livre-arbítrio.

A despeito dessa apreensão, a neurociência parece, em seu atual estágio de desenvolvimento, não impactar significativamente o debate filosófico em torno da liberdade de vontade. Isso em razão de, principalmente, não contribuir na solução tanto do "questionamento determinista", quanto do "questionamento compatibilista". Conforme observa Adina RoskiES (2006, pp. 420 e 421), a neurociência não é capaz de indicar que vivemos em um universo determinista. $\mathrm{O}$ quadro que a neurociência até o momento pôde produzir, segundo a filósofa, é um de mecanismos infundidos com processos indeterminísticos ou estocásticos (aleatórios ou probabilísticos): se um neurônio irá disparar ou não, que padrão de potenciais de ação ele gerará, ou quantas vesículas sinápticas serão liberadas, tudo isso tem sido caracterizado como fenômenos estocásticos nos melhores modelos disponíveis atualmente. Contudo, ressalta a autora, se a imprevisibilidade que percebemos é realmente devida a processos indeterminísticos, ou se é causada por processos determinísticos complexos que estão além de nossa atual compreensão, são questões que a neurociência não é capaz resolver - pelo menos por enquanto.

Sustenta ROSKIES que o indeterminismo aparente em certo grau de descrição é completamente compatível com o determinismo no nível físico fundamental. Considerando 
que um sistema determinístico pode divergir radicalmente em seu comportamento, dependendo de infinitésimas mudanças nas condições iniciais, nenhuma evidência do indeterminismo no nível dos neurônios ou de regiões de ativação teria qualquer influência na questão fundamental de se o universo é determinístico ou não. Para a professora de Dartmouth, essa é, em última análise, uma questão do campo da física, a ser respondida pela melhor teoria fundamental da natureza e de seus fenômenos, e não pela ciência que estuda o cérebro. De qualquer modo, destaca, nenhuma das técnicas que têm contribuído atualmente com a crescente angústia existencial acerca do livre-arbítrio fornece informações confiáveis a respeito do fenômeno neural de nível baixo.

Nessa linha, o que a neurociência pode indicar é que, independentemente de se o universo é ou não determinístico, o cérebro efetivamente o é. Em outras palavras, isso significa que, em algum nível mais elevado do que os movimentos e as interações de átomos e moléculas, indeterminações de nível baixo desgastam-se e a operação do sistema em nível alto passa a ser caracterizada por leis, de maneira que a atividade futura pode ser confiavelmente prevista com base na atividade passada. $\mathrm{O}$ determinismo é uma assunção à qual muitos cientistas aderem, mas que, segundo RosKIES, provavelmente permanecerá para sempre nessa condição - de mera proposição hipotética. Na visão da autora, é difícil conceber que provas adicionais poderiam nos compelir a tomar essa assunção como fato. Além disso, acrescenta, embora os sucessos científicos constituam evidência de que o comportamento é dirigido por mecanismos biológicos - em vez de por uma "alma" -, os resultados da neurociência não podem provar que somos nada além de uma máquina. Assim, uma compreensão acerca dos potenciais produtos das técnicas neurocientíficas os revelaria bastante impotentes no agravamento do atual estágio do problema do livrearbítrio. Por todas essas razões, verifica-se que os aportes da neurociência à discussão em torno da liberdade de vontade não implicam uma mudança de paradigma na questão.

É relevante notar que, se por um lado a neurociência não é capaz de minar nossas noções intuitivas a respeito do livre-arbítrio, por outro os problemas das concepções de liberdade de vontade do senso comum existem previamente aos avanços neurocientíficos, e continuarão a existir independentemente desses. Desse modo, o estado da arte da discussão filosófica sobre o livre-arbítrio parece continuar no mesmo nível de anteriormente ao advento da neurociência, vale dizer, nossa noção intuitiva de que, de alguma forma, estamos no comando de nossas próprias ações permanece em uma encruzilhada científica, 
onde, em um flanco, estão os partidários da física clássica e, de outro, ficam os defensores da física quântica de escala atômica - sendo que nenhum deles é capaz de apresentar uma resposta satisfatória acerca da liberdade de vontade.

O dilema que se apresenta é o seguinte: a física clássica descreve um universo estritamente determinista, em que cada fenômeno se segue do último de uma maneira previsível, de modo que tudo, incluindo nossas ações e a atividade cerebral que as precedem, é como é por conta do estado inicial do universo e das leis naturais que o regem - e, se esse é o caso, não podemos agir de maneira diversa da que agimos e, portanto, não somos livres; em outro polo, a física quântica de escala atômica introduz a imprevisibilidade e a incerteza como parte inerente do cosmo, de forma que, não sendo determinados, os eventos naturais, incluindo nossos comportamentos, são aleatórios, não sendo nossas ações, portanto, fruto de nossa vontade livre, mas sim do acaso - então, a aleatoriedade se apresenta tão incompatível com a ideia de livre-arbítrio quanto o determinismo (RoskIES, 2006, p. 419; EAGLEMAN, 2012, p. 180) ${ }^{64}$. Esses desafios à ideia de liberdade de vontade, embora contundentes, existem independentemente do progresso da neurociência. Logo, permanecem abertos os questionamentos "determinista" e "compatibilista", cujas propostas de solução moldam as diferentes teorias a respeito da existência do livre-arbítrio.

\subsection{Considerações finais: uma certeza e muitas dúvidas pelo caminho}

Os resultados das pesquisas neurocientíficas acerca do livre-arbítrio, apesar de pouco terem impactado o cerne do problema, produziram ao menos um aporte significativo à questão. Ao compreender os processos mentais não como entes abstratos, mas como decorrentes dos processos cerebrais, a neurociência, valendo-se do intenso desenvolvimento das técnicas de leitura da atividade cerebral, passou a identificar, de maneira sem precedentes, disfunções cerebrais com repercussão direta no comportamento humano, que até então não podiam ser identificadas.

\footnotetext{
${ }^{64}$ Há na física, ainda, a abordagem ao problema do livre-arbítrio pela teoria do caos, a partir da qual, observando a vasta complexidade do cérebro, se propõe que não há jeito, na prática, de se determinar seus movimentos seguintes. Contudo, embora certamente isso seja verdade, não resolve de maneira satisfatória a questão da existência da liberdade de vontade, porquanto os sistemas estudados na teoria do caos ainda são deterministas, de modo que um passo leva inevitavelmente ao subsequente. Apesar de ser muito difícil prever para onde vão os sistemas caóticos, cada um de seus estados tem uma relação causal com o anterior. Não se confunde, nesse sentido, um sistema imprevisível com um sistema livre (EAGLEMAN, 2012, p. 181).
} 
Essa contribuição tem impactado diretamente as áreas do conhecimento para as quais o livre-arbítrio é objeto de estudo, porque, apesar de não poder resolver o problema de se temos ou não, efetivamente, tal aptidão, permite que se identifique situações em que, certamente, a vontade não era livre ou, ao menos, não fora formada normalmente, seja por conta de desequilíbrios neurofisiológicos, seja em razão desajustes na anatomia cerebral etc. É o que ocorre, por exemplo, quando certo indivíduo apresenta comportamentos antissociais (como agressividade, promiscuidade sexual etc.), mas se constata desarranjos na parte do cérebro relacionada ao autocontrole. A possibilidade de a neurociência verificar, por meio da tecnologia que utiliza, situações de anormalidade cerebral até então não identificadas, com impacto decisivo no comportamento, já é algo sedimentado, amplamente aceito na comunidade científica.

Por outro lado, a despeito dessa certeza que a neurociência logrou produzir, suas contribuições não foram capazes de sanar muitas dúvidas que há a respeito do processo de formação de vontade no comportamento humano. Isso porque a maioria dos neurocientistas, partindo da constatação de que pequenas mudanças neurofisiológicas podem conduzir a imensas alterações de comportamento, e atentando ao fato de que as escolhas estão inseparavelmente relacionadas aos pormenores mais ínfimos da maquinaria cerebral, buscam circunscrever o ser humano à sua constituição biológica.

Trata-se do ponto de vista materialista, o qual declara que somos feitos, fundamentalmente, apenas de matéria física. Nessa perspectiva, o cérebro se apresenta como um sistema cuja operação é regida pelas leis da física e da química e, assim, todos os nossos pensamentos, emoções e decisões seriam produzidos por reações naturais, seguindo leis locais para o mais baixo potencial de energia, de maneira que o ser humano não seria outra coisa senão seu próprio cérebro, suas substâncias - e qualquer mexida nos controles do sistema neural alteraria a própria natureza do indivíduo. Uma versão comum do materialismo é denominada reducionismo, teoria segundo a qual é possível entender fenômenos complexos como a felicidade, a avareza, o narcisismo, a compaixão, a malícia, a cautela, o assombro, reduzindo-os sucessivamente a suas partes biológicas de pequena escala (EAGLEMAN, 2012, p. 218).

Contudo, conforme análise do neurocientista David EAGLEMAN (2012, pp. 224 a 239), esse ponto de vista é falho na medida em que níveis sucessivos de redução estariam condenados a dizer muito pouco sobre as questões que importam ao ser humano. Prova disso seriam os resultados do Projeto Genoma Humano, que muito embora tenha sido um 
marco da ciência contemporânea, em certo sentido revelou-se um fracasso. Nessa linha, apesar de ter-se logrado mapear o genoma humano e decodificar a sequência de bilhões de nucleotídeos que o compõe, não se encontrou as respostas inovadoras e esperadas sobre os genes exclusivos da humanidade: ao contrário, se descobriu que outros animais têm essencialmente o mesmo genoma que os seres humanos, constituindo-se do mesmo material básico, mas em configurações diferentes. Assim, por exemplo, observou-se que o genoma humano não é muito diferente do genoma do sapo, a despeito de os seres humanos serem - ou, pelo menos, parecerem - extremamente diferente dos sapos.

Uma série de estudos tem demonstrado que não só a biologia, nem só o ambiente, determinam o produto final de uma personalidade, mas uma junção interativa de ambos ${ }^{65}$. Em face disso, segundo o autor estadunidense, o reducionismo se mostra enganador por duas razões: em primeiro lugar, porque a complexidade insondável das interações geneambiente torna inviável a compreensão a respeito de como se desenvolverá qualquer indivíduo - com sua vida de experiências, conversas, maus-tratos, alegrias, alimentos ingeridos, drogas recreativas consumidas, remédios tomados, aprendizados adquiridos etc.; em segundo lugar, embora seja verdade que estamos ligados a nossas moléculas, proteínas e neurônios, não decorre disso, pela lógica, que o ser humano é mais bem descrito por seus componentes, na medida em que o fato de um sistema ser feito de partes, e essas serem fundamentais para o funcionamento daquele, não significa que as partes representem o nível correto de descrição.

Nesse sentido, EAGLEMAN assere que o reducionismo não explica satisfatoriamente a relação entre o cérebro e a mente em razão, especialmente, de uma característica denominada emergência. A ideia, aqui, é a de que quando se agrega um grande número de componentes, o todo pode se tornar algo maior que a soma das partes. É o caso, por exemplo, do avião, no qual nenhum de seus componentes de metal tem, isoladamente, a propriedade de voar, mas quando unidos da maneira correta, o resultado ganha o ar. O conceito de propriedades emergentes implica que se pode introduzir algo novo que não é inerente a nenhuma de suas partes. Desse modo, embora a mente dependa da integridade dos neurônios para produzir pensamentos, aqueles não são, por si próprios, pensantes.

\footnotetext{
${ }^{65}$ Pesquisas voltadas ao estudo das interações gene-ambiente no ser humano: (i) no desenvolvimento do transtorno da depressão, em pessoas que passaram por eventos traumáticos (CASPI; SUGDEN; MOFFITT et al., 2003); (ii) no desenvolvimento de comportamento abusivo, em pessoas que sofreram abuso na infância (CASPI; MCCLAY; MOFFITT et al., 2002); (iii) no desenvolvimento de psicose, por fumo de cannabis sativa na adolescência (CASPI; MOFFITT; CANNON et al., 2005); e (iv) no desenvolvimento de personalidade antissocial, em pessoas com história de experiências ambientais adversas (SCARPA; RAINE, 2003).
} 
Assim, uma teoria significativa da biologia humana não pode ser reduzida à química e à física, mas deve ser compreendida em seu próprio vocabulário de evolução, competição, recompensa, desejo, reputação, avareza, amizade, confiança, fome e assim por diante.

Em suma, seguir uma direção única rumo ao muito pequeno, aos componentes do sistema, se mostra um erro cometido pelos reducionistas, de maneira que parece pouco provável que a neurociência entenda o cérebro apenas a partir do estudo das interações neuronais. O futuro da compreensão da mente, assim, aparenta estar na decodificação dos padrões de atividade existentes acima da matéria úmida - e não nela mesma -, padrões esses dirigidos tanto por maquinações internas, como por interações com o mundo externo. Contudo, apesar de haver laboratórios em todo o planeta buscando entender a relação entre a matéria física e a experiência subjetiva e suas diversas manifestações - aqui inclusa a percepção de liberdade de vontade -, ainda se está longe de solucionar o problema.

Diante desse quadro de incerteza persistente acerca da existência de livre-arbítrio, a cuja resolução a neurociência, aparentemente, não é capaz de colaborar em curto (e talvez médio) prazo, e em face do pouco conhecimento que ainda há acerca de como operam os mecanismos de formação da vontade no cérebro humano, indaga-se: justifica-se a manutenção do modelo atual de responsabilidade penal, com a culpabilidade como é hoje compreendida (vale dizer, em sua concepção mais difundida e aceita, qual seja, a finalista)? Considerando-se a realidade mencionada, faz sentido buscar alternativas teóricas à culpabilidade, em estruturas não fundamentadas na liberdade de vontade? Em caso de resposta afirmativa a essa última questão, alguma das formulações alternativas à culpabilidade finalista, existentes atualmente, se mostraria adequada ou suficiente na substituição daquela concepção na teoria do delito? São esses questionamentos que nortearão o desenvolvimento da próxima etapa do trabalho. 


\section{NEUROCIÊNCIAS E CULPABILIDADE}

\subsection{Considerações introdutórias: a neurociência como realidade nos tribunais (investigação do cérebro e aferição da imputabilidade do agente)}

Embora não tenha contribuído decisivamente para a solução da questão da existência do livre-arbítrio, a neurociência, por meio de técnicas de leitura da atividade cerebral, tem sido capaz de identificar disfunções no sistema nervoso central que repercutem diretamente no comportamento humano, inclusive em condutas socialmente desajustadas ou criminosas - conforme detalhadamente se expôs no capítulo anterior. Essa contribuição da neurociência tem impactado não somente discussões teóricas em torno da culpabilidade, como também já produz consequências de ordem prática, sendo utilizada como meio de prova em processos penais, principalmente no que diz respeito a arguições defensivas de inimputabilidade.

A neurociência, assim, já se revela como uma realidade em diversos tribunais, notadamente em países estrangeiros, como os Estados Unidos da América, o Reino Unido e a Índia, onde a leitura da atividade cerebral (especificamente, o "neuroimageamento") tem sido utilizada como prova técnica no processo penal para várias finalidades, dentre as quais: (i) demonstrar que o réu tinha uma condição mental que o tornava inapto para ser interrogado perante o Juízo; (ii) indicar que o acusado tinha conhecimento experimental (ou memória) da perpetração do crime; e, especialmente, para (iii) arguir a mitigação da culpabilidade do autor do injusto penal, seja em razão de anormalidades cerebrais, seja por conta do desenvolvimento incompleto do sistema nervoso central, no caso de adolescentes (The Royal Society, 2011, pp. 14 a 17; Church, 2012, pp. 1.826 a 1.831). Contudo, apesar da utilização cada vez mais frequente de exames neurológicos como prova técnica muitas vezes aliada ao depoimento de neurocientistas, na condição de peritos ou assistentes técnicos -, ainda não está claro, no atual estágio de desenvolvimento científico, qual o nível de confiabilidade dessa espécie de elemento de informação na consecução daquelas finalidades.

Há, certamente, casos em que o neuroimageamento permitiu, com sucesso, atestar que disfunções cerebrais foram as responsáveis por comportamentos criminosos, isentando o autor do fato de responsabilidade penal por conta de sua inimputabilidade. Nesse sentido, o caso conhecido como "pedofilia adquirida" é emblemático. Segundo reporta a literatura 
médica (BuRns; Swerdlow, 2003, pp. 437 e 438), um homem de quarenta anos e condições gerais normais de saúde começou a demonstrar um crescente interesse em pornografia, especialmente pornografia infantil, de maneira que passou a despender tempo e energia em visitas a sites com conteúdos desse jaez, assim como a solicitar serviços de prostitutas, algo que até então jamais havia feito. Além disso, o paciente, que era casado, passou também a fazer avanços sexuais sutis em direção à sua enteada pré-adolescente. Depois que a enteada informou a esposa do paciente acerca de seu comportamento - e descobriu-se os demais detalhes a respeito -, ele foi legalmente removido do lar e, posteriormente, considerado culpado em Juízo por estupro de vulnerável ("child molestation", na legislação estadunidense). Um dia antes de sua sentença ser prolatada, devido a fortes dores de cabeça, o paciente foi levado ao atendimento de emergência de um hospital, onde, por meio da realização de exame de ressonância magnética (MRI) em seu cérebro, revelou-se um tumor imenso na região do córtex orbitofrontal. Com o diagnóstico, o paciente foi submetido à cirurgia para retirada do tumor, e em pouco tempo seu comportamento sexual voltou ao normal.

Essa situação é explicada pelo fato de o córtex orbitofrontal ser a parte do cérebro envolvida na regulação do comportamento social. Assim, lesões adquiridas na infância podem levar a uma resistência na aquisição de conhecimento social e moral, o que pode resultar em falhas no julgamento, redução no controle de impulsos e personalidade antissocial. Uma personalidade antissocial adquirida pode ser derivada também de danos cerebrais ocorridos no início da idade adulta (como ocorreu com o paciente acima citado, que aos vinte e quatro anos de idade sofrera uma contusão na cabeça, seguida de dois minutos de perda de consciência), resultando em processos de tomada de decisão que enfatizam a recompensa imediata, em detrimento dos ganhos de longo prazo, prejudicando a habilidade do indivíduo de se portar adequadamente em situações sociais - o que, no extremo, pode levar a comportamentos sociopáticos (THE ROYAL SOCIETY, 2011, p. 16).

No exemplo atrás reportado, o papel do tumor nas condutas socialmente desajustadas do paciente é reforçado pela sequência inesperada do caso: cerca de seis meses após sua cirurgia no cérebro, começou a apresentar novamente comportamento pedófilo. Tendo sido levado mais uma vez à consulta médica, foi descoberto, pelo neurorradiologista, que uma parte do tumor escapara à operação e estava crescendo. O paciente, então, foi submetido a nova cirurgia para retirada do resto do tumor e, após o procedimento, tornou a apresentar comportamento normal. 
Conquanto haja, como esse, exemplos bem sucedidos do uso da neurociência para aferir a imputabilidade do autor de um injusto penal - vale dizer, para averiguar se seu comportamento foi produzido em condições cerebrais normais ou se é fruto de disfunções neurológicas -, ainda é necessária precaução na utilização desse tipo de conhecimento no meio forense. Isso porque, como explicam Adina RoskIES e Walter SinNOTT-ARMSTRONG (2011 [2], pp. 106 e 107), a noção de normalidade cerebral é difícil de ser acessada por meio de neuroimageamento, pois a maioria dos estudos neurocientíficos que utilizam ressonância magnética funcional reportam uma média do grupo analisado, mas os perfis funcionais individuais podem variar de tal maneira que se revela usual que a maior parte dos indivíduos difiram do padrão médio observado no grupo. Assim, meros desvios da média, ainda que significativos, na maioria das vezes não apresentam qualquer repercussão em aferições de anormalidade que sejam relevantes do ponto de vista da imputação penal ${ }^{66}$.

Além disso, segundo os autores, mostra-se bastante comum que a execução de uma tarefa possa ser desempenhada por meio de mais de um processo cerebral diferente. Nesse sentido, por exemplo, atividades com certo nível de complexidade, que demandem aprendizado e controle cognitivo, podem apresentar processos cerebrais variáveis na população, por conta da plasticidade cerebral ${ }^{67}$ e também em razão de a realização da tarefa poder prestar-se a múltiplas estratégias de execução. Em alguma medida, indivíduos diferentes podem simplesmente processar a mesma informação de maneiras distintas, mesmo quando nenhum deles é de qualquer modo "anormal" - ao menos do ponto de vista do impacto na responsabilidade penal. Assim, um menor nível de atividade em certas áreas cerebrais pode indicar, para algumas pessoas, que a tarefa foi fácil para elas, de maneira que as realizaram com maior rapidez, ao passo que, em outras pessoas, a atividade cerebral reduzida pode revelar que elas não consideraram certos fatores importantes para a execução da tarefa. Em face disso, sustentam esses neurofilósofos que a gama de variabilidade individual na arquitetura funcional do cérebro representa um problema real na utilização de neuroimageamento para determinar anormalidades cerebrais relevantes da perspectiva do direito penal.

\footnotetext{
${ }^{66}$ Ao tratar-se da anormalidade relevante do ponto de vista da imputação penal, está-se referindo à disfunção cerebral que repercute diretamente no comportamento do indivíduo de tal maneira que, impactando aptidões mentais como a cognição, o autocontrole, entre outras, leva-o à prática de condutas penalmente tipificadas.

${ }^{67}$ As células do sistema nervoso não são imutáveis. Ao reverso, são dotadas de plasticidade, o que significa que os neurônios podem modificar, de modo permanente ou pelo menos prolongado, a sua função e a sua forma, em resposta a estímulos do ambiente externo. A plasticidade é maior durante o desenvolvimento, e declina gradativamente, sem se extinguir na vida adulta. Manifesta-se de diversas formas: regenerativa, axônica, sináptica, dendrítica e somática (LENT, 2010, p. 148).
} 
ROSKIES e SINNOTT-ARMSTRONG ressaltam, ademais, que a variabilidade individual na leitura funcional do cérebro depende de três fatores principais, também variáveis de indivíduo para indivíduo: a estrutura cerebral subjacente, a arquitetura funcional do cérebro e a estratégia e a performance na execução da atividade em questão. Determinar quanto da variabilidade individual se deve a cada um desses aspectos é uma tarefa difícil, mas cientificamente viável, à qual muitos cientistas estão atualmente se dedicando. A aferição das variabilidades individuais em função da distribuição estrutural e funcional do cérebro na realização das mais diversas ações se revela necessária para fins de estabelecimento de padrões a partir dos quais conclusões relacionadas à capacidade de culpabilidade podem ser atingidas. Esses dados devem revelar as diferenças estatísticas significativas entre populações, de maneira que variáveis atribuíveis a diferenças individuais em grupos normais de pessoas não sejam consideradas.

De tudo isso, verifica-se que a intersecção entre as neurociências e o direito penal (particularmente, a culpabilidade), apesar de incipiente, isto é, carente de maior aprofundamento teórico, já existe, tratando-se de realidade constatável na prática forense. Diante desse contexto, avaliar quais são as formas que o estudo do cérebro pode impactar a imputação penal, e quais são os limites teóricos da conexão entre essas duas disciplinas, é tarefa que se revela necessária, e que se buscará desempenhar ao longo desse capítulo.

\subsection{A hipótese da transgressão penal enquanto indício de anormalidade cerebral: discussões acerca da posição da imputabilidade na estrutura de imputação e da intervenção cerebral como resposta estatal ao delito}

$\mathrm{Na}$ concepção normativa da culpabilidade, com os aportes da teoria finalista de WELZEL, para que se reprove o autor de um injusto penal por sua conduta é necessário que ele pudesse ter agido de outro modo, vale dizer, com liberdade de vontade. Pressuposto dessa liberdade de vontade é a imputabilidade do agente, isto é, sua capacidade de compreensão (do caráter ilícito do comportamento) e de autodeterminação (segundo tal compreensão), um mínimo grau de maturidade e discernimento para que exista uma decisão censurável.

$\mathrm{Na}$ legislação brasileira, nos termos da redação do artigo 26 do Código Penal, os inimputáveis são aqueles desprovidos daquela capacidade intelectual (de compreensão e de autodeterminação), quando essa decorrer de uma destas três razões: (a) doença mental; (b) 
desenvolvimento mental incompleto; ou (c) desenvolvimento mental retardado (RodríGUEZ, 2010, pp. 278 e 279). Conforme explica Víctor Gabriel RodríGUEZ (2010, pp. 278 e 279), a aferição da inimputabilidade passa por um duplo crivo: o psicológico, consistente na incapacidade de compreensão e de autodeterminação; e o biológico, relacionado à existência de uma daquelas três condições mentais citadas. Daí se denominar biopsicológico o critério adotado no Brasil para a aferição da inimputabilidade: sua declaração depende da coexistência tanto do critério biológico, quanto do critério psicológico.

Como se tem observado nesse trabalho, a neurociência, valendo-se largamente do desenvolvimento das técnicas de leitura da atividade cerebral, tem colaborado ativamente na identificação de disfunções cerebrais que, com o conhecimento disponível em tempos passados, permaneciam inacessíveis aos médicos e aos pesquisadores. A partir de investigações acerca do funcionamento do cérebro humano, os neurocientistas têm sido eficazes, também, em relacionar determinadas anormalidades no sistema nervoso central a certos padrões de comportamento - nos quais estão incluídos aqueles socialmente desajustados ou criminosos. Assim, com a atestada associação, em alguns casos, entre condições neurológicas e condutas delituosas - seja por falhas no sistema de autocontrole, seja por defeitos nos mecanismos de recompensa, ou ainda por outras razões -, a neurociência já tem sido utilizada na prática forense como meio de prova para a aferição da inimputabilidade de um acusado criminal.

Todavia, conforme se abordou tangencialmente no final do capítulo "4.3.1.1. Aportes da neurociência à questão da indemonstrabilidade empírica", para determinados estudiosos da intersecção entre neurociências e Direito - por alguns denominada "neurodireito" (ou, no termo original, em inglês: "neurolaw") - não faz sentido que a culpabilidade seja determinada pelos limites da tecnologia disponível à época. A ideia, aqui, é de que a ciência evoluirá continuamente, e à medida que melhorar a medição dos problemas do cérebro, aumentará o espectro da inimputabilidade. Em outras palavras, com novos instrumentos e novas técnicas, condições cerebrais atualmente ocultas se abririam ao exame, possibilitando, no futuro, a descoberta da explicação biológica subjacente a cada conduta socialmente desajustada - como já ocorreu, em tempos passados, com os comportamentos relacionados à esquizofrenia, à epilepsia e à depressão.

Tendo em conta essa perspectiva, e considerando que o comportamento de um indivíduo não está divorciado de sua neurofisiologia, essa corrente de pesquisadores em 
neurodireito argumenta que qualquer comportamento anormal - dentre os quais, o criminoso - é causado por problemas na função cerebral, tais como mutações genéticas, desequilíbrios hormonais ou nos níveis de neurotransmissores, além de tumores e acidentes vasculares. Desse modo, ainda que não se consiga medir, com os conhecimentos disponíveis no presente, o que há de errado no cérebro do autor de um delito, poder-se-ia pressupor, com boa segurança, que há ali uma anormalidade, uma vez que os atos daquele sujeito seriam prova suficiente da existência uma disfunção cerebral, mesmo que (ainda) não se conheça os detalhes a respeito (SINGER, 2004).

Diante desse quadro, David EAgleman (2012, pp. 189 a 199), diretor do grupo multidisciplinar de pesquisa "Initiative on neuroscience and law" (ou "Iniciativa sobre neurociência e direito"), do Baylor College of Medicine, nos Estados Unidos, sustenta que os autores de crimes devem ser sempre tratados como incapazes de ter agido de outra maneira. Seu argumento é o de que a atividade delituosa deve ser tomada, em si, como evidência de anormalidade cerebral, independentemente de se é possível situá-la entre os problemas atualmente mensuráveis. Assim, defende que o critério da imputabilidade deve ser afastado da estrutura de atribuição de responsabilidade penal e da consequente imposição de pena, pois, de acordo com a perspectiva proposta, tal elemento careceria de sentido. Na mesma direção, advoga que as provas produzidas por meio da neurociência sejam excluídas do processo penal, tendo em vista que refletiriam apenas se há hoje medições e designações para os transtornos cerebrais dos quais decorreu o comportamento criminoso, e não se tais problemas de fato existem.

Em face dessa visão do fenômeno criminal, EAGLEMAN propõe um modelo de punição calcado principalmente na prevenção especial ${ }^{68}$. Segundo sua compreensão, um conhecimento biológico mais aprofundado do comportamento humano permitirá um entendimento melhor da reincidência, o que possibilitará essa guinada teórica no que diz respeito à pena, em direção a julgamentos mais racionais - e, portanto, mais justos -, apropriados às características individuais de cada pessoa - do ponto de vista de sua constituição cerebral -, já que a ciência viabilizará a análise da probabilidade de recidiva de cada condenado.

\footnotetext{
${ }^{68}$ No mesmo sentido, Joshua GREENE e Jonathan COHEN (2004, pp. 1.775 a 1.785) defendem, também com base nos conhecimentos neurocientíficos, uma estrutura de responsabilização penal alicerçada no consequencialismo ("consequentialism") - isto é, na justificação da punição por seus efeitos benéficos futuros (prevenção de crimes do porvir pelo efeito dissuasivo da lei e contenção de indivíduos perigosos) -, ao invés de no retributivismo ("retributivisim") - vale dizer, na legitimação da pena pelo merecimento e como compensação do mal causado pelo crime.
} 
De acordo com o autor, é impossível que o sistema judiciário, ainda que com o auxílio da ciência, possa prever com alto grau de certeza se um condenado reincidirá ou não. Isso porquanto o comportamento humano é em grande medida imprevisível - em razão da interação em níveis inimaginavelmente complexos entre genes e ambiente -, e também porque a conduta recidiva depende de vários fatores - dentre os quais circunstância e oportunidade. Contudo, a despeito disso, sustenta que por trás de práticas criminosas de mesma espécie há padrões de comportamento identificáveis, que, uma vez dissecados e categorizados, permitiriam prospectar quais indivíduos têm maior probabilidade de tornar a perpetrar delitos, necessitando, portanto, de punição mais rigorosa.

Essa visão de EAGLEMAN é formada com base em um estudo levado a efeito com criminosos sexuais no sistema judiciário estadunidense (cf. HANSON; MORTON-BOURGON, 2005). Em uma pesquisa de larga escala, analisou-se dezenas de fatores de 22.500 condenados prestes a serem libertados: se tiveram um relacionamento conjugal por mais de um ano, se sofreram abuso sexual na infância, se eram viciados em drogas, se mostraram remorso por suas atitudes etc. Tendo acompanhado tais indivíduos por cinco anos após a soltura, e verificado quais deles retornaram ao cárcere, os pesquisadores computaram quais fatores melhor explicavam as taxas de reincidência, e a partir desses dados montaram tabelas atuariais (voltadas à avaliação e administração de riscos) para que fossem usadas como parâmetro para a imposição de pena em processos judiciais futuros. Comparando-se o poder de previsão dessa abordagem atuarial com a opinião de psiquiatras e de agentes de condicional, os números se mostraram muito mais eficazes do que a intuição desses profissionais com experiência na área, de modo que aquele método passou a ser utilizado pelos magistrados de todos os Estados Unidos na fixação da sanção penal, especificamente na definição do tamanho da pena aplicada - vale dizer, do tempo de afastamento do condenado da convivência em sociedade. Para o neurocientista, à medida que as ciências do cérebro forem introduzidas nessas medições - com estudos de neuroimageamento, por exemplo -, a capacidade de previsão da reincidência só aumentará, oferecendo conjecturas cada vez mais seguras desse fenômeno.

Além das sentenças customizadas, mais adequadas às características individuais de cada condenado, bem como voltadas ao seu comportamento futuro, o professor do Baylor College defende que uma compreensão mais prospectiva do sistema de justiça, que se valha dos conhecimentos de neurociência, possibilitará a superação da pena privativa de 
liberdade enquanto paradigma de resposta estatal ao crime, abrindo espaço para abordagens voltadas não mais à punição (enquanto retribuição), mas sim à reabilitação. Nesse contexto, a intervenção cerebral surge como alternativa à prisão. Consciente dos problemas éticos e das questões humanas envolvendo a experiência com as lobotomias frontais ${ }^{69}$, EAGLEMAN propõe um modelo menos invasivo, que denomina "treinamento préfrontal", no qual a reabilitação e a reintegração do condenado à sociedade são orientadas de acordo com o objetivo ético de alterar o mínimo possível o indivíduo.

O treinamento pré-frontal parte da compreensão do cérebro enquanto organismo constituído por populações neurais distintas, que competem entre si buscando a prevalência no processo de tomada de decisão e de realização da ação. Além disso, fundamenta-se na concepção de que é uma característica marcante do fenômeno criminal o fraco controle dos impulsos por parte dos autores de injustos penais, isto é, o fato de saberem a diferença entre um comportamento conforme e um contra o mandamento normativo - e compreenderem as consequências da infração à norma -, mas serem incapazes de autocontrolarem seus ímpetos ilícitos, de maneira que a tentação em receber recompensa imediata supera a preocupação com o futuro (cf. STANFORD; BARRATT, 1992; KENNEDY; GRUBIN, 1990).

Levando em conta que no caso de comportamentos criminosos os circuitos do lobo frontal que representam as considerações de longo prazo não conseguem prevalecer sobre os desejos de curto prazo, a estratégia de reabilitação do treinamento pré-frontal é precisamente promover nos lobos frontais a prática na repressão dos circuitos de curto prazo. A ideia, aqui, é estabelecer um bom sistema de controles, cultivando a reflexão antes da ação, estimulando o indivíduo - no caso, o condenado -, diante de conjunturas de tentação, a treinar o autocontrole enquanto sua atividade cerebral é lida por meio de técnicas de neuroimageamento, permitindo que sejam visualizadas as partes do cérebro que necessitam de modulação e, assim, sejam testemunhados os efeitos das diferentes abordagens mentais assumidas perante a situação. Tal procedimento mostra-se possível

${ }^{69}$ A lobotomia frontal, originalmente denominada leucotomia, é um procedimento cirúrgico criado pelo médico português António EGAS MonIz (prêmio Nobel de Fisiologia ou Medicina de 1949), consistente na secção das conexões para e do córtex pré-frontal, resultando em grandes mudanças na personalidade do paciente - incluindo possível retardo mental. Tal procedimento, por "acalmar" os pacientes - na verdade, eram deixados em estado quase vegetativo -, passou a ser utilizado em indivíduos institucionalizados - como inimputáveis mantidos em clínicas de saúde mental e condenados cumprindo pena em estabelecimentos prisionais - para que fossem devolvidos à vida privada, deixando, assim, de ser uma preocupação do Poder Público. Apesar de bem-sucedida do ponto de vista da evitação do comportamento socialmente desajustado, a lobotomia deixou de ser considerada uma abordagem adequada à conduta criminosa, notadamente por conta de reflexões de cunho bioético, consistentes nos limites da legitimidade de o Estado intervir na constituição orgânica, violando a integridade física, de seus cidadãos (EAGLEMAN, 2012, pp. 194 e 195). 
com o aperfeiçoamento das técnicas de imageamento cerebral voltadas a viabilizar a visualização das respostas dos pacientes em tempo real - tecnologia que, conquanto rudimentar, já vem sendo desenvolvida (cf. CHIU et al., 2009).

Em síntese, EAGLEMAN explica que, considerando que os lobos frontais são a parte do cérebro responsável pelo desenvolvimento de circuitos responsáveis pela repressão dos impulsos - e, portanto, por posturas socialmente ajustadas -, o objetivo do treinamento préfrontal é conferir maior controle às populações neurais relacionadas à prevalência das consequências de longo prazo, estimulando a reflexão e inibindo a impulsividade, de maneira a melhorar a capacidade do indivíduo para a tomada de decisão de longo prazo.

Do ponto de vista bioético, o neurocientista argumenta que o treinamento préfrontal não possui nenhum óbice, na medida em que mantém o cérebro intacto, pois não recorre à ministração de fármacos, nem à realização de cirurgias, simplesmente promovendo os mecanismos naturais da plasticidade cerebral em um modelo no qual o próprio indivíduo é o responsável por sua recuperação - ainda que por imposição do Estado. A neuroplasticidade, inclusive, por sua posição fulcral nessa estrutura proposta de reabilitação, se apresentaria como parâmetro de fixação da pena: a capacidade de modificação cerebral de cada indivíduo nortearia a determinação das características forma, tempo, etc. - de sua punição, já que algumas pessoas têm cérebros que reagem melhor ao condicionamento clássico (castigo e recompensa), enquanto outras - em virtude de disfunções neurológicas (por exemplo: a psicopatia, a esquizofrenia e a depressão, além de outras condições que afetam os níveis de dopamina no sistema nervoso central) - são mais refratárias à mudança (cf. BUCKHOLTZ et al., 2010, pp. 419 a 421; JUCKEL et al., 2006, pp. 409 a 416; MARTIN-SOELCH, 2009, pp. 313 a 317; DREHER et al., 2009, pp. 617 a $622)$.

A despeito de reconhecer que o treinamento pré-frontal ainda encontra-se em seu estágio inicial de desenvolvimento, o professor estadunidense considera promissora essa modalidade de reabilitação, por estar, de sua perspectiva, bem fundamentada tanto na biologia, quanto na ética, apresentando-se como uma alternativa viável e adequada ao criticado e combalido modelo encarcerador.

O modelo de reabilitação proposto por EAGLEMAN, consistente em intervenção indireta no cérebro, por meio da realização de atividades que estimulam os lobos frontais na repressão dos circuitos de recompensa de curto prazo, ainda não foi submetido a 
escrutínio por parte da doutrina penal. Por se tratar o treinamento pré-frontal de proposta ainda incipiente, dependente do aperfeiçoamento da tecnologia de leitura da atividade cerebral para começar a ser testada - e assim ter sua viabilidade e eficiência colocadas à prova -, tem passado ao largo das discussões travadas no campo do direito penal.

De outro turno, a intervenção cerebral direta, por meio de técnicas e procedimentos experimentais de melhora, aperfeiçoamento ou fortalecimento ("enhancement") de características, capacidades ou habilidades mentais, de forma permanente ou temporária, em razão de já constituir uma realidade nas neurociências, tem atraído a atenção dos penalistas, preocupados em verificar qual o papel do direito penal frente a esse advento do desenvolvimento científico. A esse respeito, destacam-se os trabalhos de Reinhard Merkel (2011, pp. 41 a 78) e Carlos Maria Romeo CASABOnA (2013, pp. 161 a 183).

Ao abordar o assunto, MERKEL (2011, pp. 41 a 78) inicialmente define o conceito de "enhancement" como cada procedimento idôneo ou possivelmente idôneo para criar uma situação modificada em nível fisiológico ou mental, a qual: (i) não pode ser definida como resultado de um tratamento curativo - isto é, de um recurso terapêutico voltado ao combate de uma enfermidade ${ }^{70}$; e (ii) é percebida pela pessoa, em pelo menos um aspecto, como melhora - vale dizer, como aquisição de uma vantagem que não se tinha.

Nessa linha, explica o autor que um "enhancement" das faculdades cognitivas, emocionais e motivacionais do cérebro - ou da mente - pode ser realizado por diversos meios, dentre os quais: (a) o genético; (b) o farmacológico ${ }^{71}$; (c) o eletromagnético estimulação magnética transcraniana e estimulação por ultrassom (não invasivas), além de estimulação cerebral profunda ("deep brain stimulation"; invasiva) ${ }^{72}$; (d) o cirúrgico implantação de próteses neuronais (interfaces cérebro-máquina) e transplante intracraniano de tecido celular (especialmente células-tronco neuronais ou embrionárias); e (e) o

\footnotetext{
${ }^{70}$ Aqui compreendida como qualquer divergência prejudicial e suficientemente grave do estado normal do funcionamento biológico-fisiológico-psicológico do organismo do ser humano (MERKEL, 2011, p. 53).

${ }^{71}$ Por exemplo, a ministração de modafinila, um estimulante utilizado no tratamento da neuroepilepsia, que gera uma elevação nos níveis de dopamina no cérebro, aumentando, em pessoas sãs, algumas funções cognitivas e executivas, tais como: estado de alerta, concentração, memória, tomada de decisões etc. (MERKEL, 2011, pp. 43 a 45).

${ }^{72}$ Um exemplo da utilização desse procedimento é a implantação de eletroestimuladores em ambos os lados da região cerebral do nucleus accumbens para a produção artificial de sensações de recompensa por meio da emissão de dopamina, a qual aumenta a motivação para a realização de determinada atividade (MERKEL, 2011, pp. 46 e 47).
} 
optogenético $^{73}$ - estimulação celular por luz (combinação dos métodos genético, eletromagnético e cirúrgico) ${ }^{74}$.

Na concepção do professor de Hamburgo, diante da evolução da neurociência e do consequente desenvolvimento das técnicas de melhoramento cerebral, não cabe ao Direito decidir, de forma autônoma, segundo seus próprios princípios, sobre questões de proibição ou autorização. Em sua análise, enquanto não haja clareza a respeito da posição da sociedade frente aqueles procedimentos - isto é, se são eticamente aceitáveis ou não -, a autonomia do Direito para resolver tal questionamento, de uma perspectiva de lege ferenda, se revela uma ilusão. Todavia, a despeito desse entendimento, busca o pesquisador examinar a compatibilidade da intervenção cerebral direta com direito penal, o que faz desde o prisma da teoria do bem jurídico.

Assim, limitando sua verificação ao "enhancement" das próprias faculdades mentais - isto é, quando a pessoa realiza a intervenção em seu próprio corpo (com o consumo de neurofármacos, por exemplo) ou o faz, consentindo, com a ajuda de um terceiro, normalmente um médico (verbi gratia, por meio de estimulação magnética transcraniana) -, MERKEL afirma que dois tipos de bens jurídicos podem ser lesionados com a realização de procedimentos dessa natureza: bens individuais da pessoa afetada e bens coletivos da sociedade. Acerca dos bens jurídicos individuais, assere que os "enhancements" mentais requerem intervenções no cérebro, de maneira que podem resultar em lesão da integridade física do afetado se realizadas sem seu consentimento. Assim, a questão de uma eventual punibilidade da intervenção cerebral demandaria a análise sobre a existência e a extensão de possíveis limitações do consentimento. No que tange ao aspecto físico da intervenção, afirma que o $§ 228$ do Código Penal alemão ("Strafgesetzbuch" $\mathrm{StGB})^{75}$ poderia representar essa limitação. No que se refere ao lado psíquico, entende não ser fácil encontrar uma resposta, muito embora reconheça que aquele dispositivo legal

\footnotetext{
73 Optogenética é a combinação de métodos ópticos e genéticos voltados a atingir ganhos ou perdas de função de eventos bem definidos em células específicas do tecido vivo. Em sentido amplo, a optogenética engloba uma tecnologia básica - ferramentas segmentáveis de controle que reagem à luz e liberam funções efetoras - e tecnologias facilitadoras para: fornecimento de luz nos tecidos sob exame; direcionamento das ferramentas de controle para as células de interesse; e obtenção de leituras compatíveis e efetuação de análises, tais como imageamento focado ou gravação elétrica da atividade evocada (DEISSEROTH, 2010, p. 1).

${ }^{74}$ Um exemplo hipotético é a introdução no cérebro de uma pessoa, por meio de um retrovírus inativado, de dois genes alheios, um de uma bactéria, outro de uma alga marinha, com o intuito de se estimular determinadas células neuronais relacionadas à capacidade cognitiva, as quais são sensíveis à luz, e têm sua atividade aumentada toda vez que recebem impulsos de um laser de cor azul (MERKEL, 2011, pp. 48 a 51).

75 "§ 228. Consentimiento. Quien efectúe una lesión personal con consentimiento del lesionado, entonces solo actúa antijurídicamente, cuando el hecho a pesar del consentimiento vaya en contra de las buenas costumbres." (ALEMANHA, 1999).
} 
também possivelmente constitui uma restrição, vale dizer: a intervenção corporal seria inadmissível porque suas finalidades de melhora mental são contrárias aos bons costumes. De maneira similar, pensa que o $§ 228$ do StGB poderia abrir caminho para a proteção de bens jurídicos coletivos: a afetação grave dos interesses da sociedade por meio da intervenção cerebral individual converteria tal procedimento em contrário aos bons costumes.

Levando em consideração o papel dos bons costumes no exame da adequação do "enhancement" cerebral aos postulados do direito penal alemão, MERKEL assinala que apesar de existirem, de fato, razões a favor da proteção legal da autodeterminação mental, não se deve perder de vista que a discussão sobre problemas normativos da intervenção cerebral é altamente ideológica - o que se atestará em um futuro próximo, já que esse debate foi recém inaugurado na Alemanha. Em sua compreensão, enquanto não se tenha convicções fundamentais de cunho social e ético relativamente consensuais sobre o tema, as proibições penais deveriam ser limitadas à proteção da autodeterminação mental contra intervenções de terceiros sem o consentimento do afetado. Para o penalista, não há na atualidade argumentos a favor de uma punibilidade dos "neuroenhancements" em pessoas autônomas que hajam prestado sua aquiescência a tanto ou que tenham realizado a intervenção em si próprias.

Desse modo, aduz o doutrinador que a noção de "contrariedade aos bons costumes", quando relacionada ao "enhancement" cerebral, deve ser interpretada de forma restritiva nos casos da existência de um consentimento - o que também se aplicaria a requerimentos de constatação de efeitos sociais que merecem uma proibição, os quais poderiam motivar o legislador a intervir na questão. Na sua visão, um direito penal liberal não deve declarar-se competente diante de opiniões generalizadas, por vezes fantasiosas, sobre a evolução tecnológica do ser humano, sem antes analisá-las detidamente. Até porque, complementa, a prática de melhoramento cognitivo e emocional por meio de intervenção cerebral também pode render efeitos altamente positivos para a sociedade.

Romeo CASABONA (2013, pp. 161 a 183), ao tratar do tema, aproxima-se em grande medida do pensamento de MERKEL. Preliminarmente, o autor espanhol observa que os intentos de melhora ou aperfeiçoamento de características corporais ou faculdades mentais dos seres humanos não são uma novidade, remontando, alguns deles, a épocas remotas e gozando, muitas vezes, de ampla aceitação social. São exemplos de procedimentos dessa 
espécie as intervenções cosméticas, o fortalecimento transitório da memória por meio de medicamentos e a dopagem voltada à prática desportiva de alto rendimento. Nesse sentido, como decorrência natural desse processo já há tempos em curso, o "neuroenhancement" surge com aquelas mesmas finalidades, apresentando técnicas mais sofisticadas e potencialmente mais efetivas, demandando novas reflexões da sociedade, além da necessidade de se tomar decisões jurídicas de natureza e envergadura diversas e sem precedentes - algumas delas, inclusive, a partir do marco dos direitos fundamentais e, possivelmente, também de caráter penal.

Partindo de uma caracterização de "enhancement" cerebral muito próxima à de MERKEL, e diante desse quadro preliminar retratado, ROMEO CASABONA sustenta que as intervenções e os procedimentos que não são dirigidos somente ao tratamento e à prevenção de enfermidades relacionadas ao cérebro, mas voltados à melhora ou potencialização profunda, permanente e irreversível de certas capacidades psíquicas ou intelectuais deveriam, antes de ser regulamentadas por meio de um marco legal, submeterse a um amplo debate social sobre sua pertinência, em particular em relação à oportunidade de decisões a respeito de sua licitude. Além disso, defende que os profissionais do setor médicos, especialmente - deveriam assumir uma postura autorregulatória, comprometendose a não realizar tais práticas enquanto não estejam bem constatados seus efeitos de médio prazo - e não unicamente suas sequelas imediatamente constatáveis.

O Direito, para o professor de Bilbao, há de ser um instrumento garantidor da soberania da vontade social, devendo ser compatível, em princípio, com o respeito das opções individuais, notadamente quando essas repousam sobre a titularidade de direitos fundamentais. Assim, a intervenção jurídica somente se justifica se a sociedade tiver se pronunciado sobre a legitimidade, ou não, inclusive restritiva, desses adventos científicos. Não obstante, as garantias fundamentais e as liberdades públicas reconhecidas nas Constituições políticas dos Estados, assim como em tratados internacionais de direitos humanos, devem, segundo o autor, constituir uma barreira que limite o uso de certas técnicas ou procedimentos de aperfeiçoamento, ainda que o afetado, no pleno exercício de sua autonomia de vontade, tenha com aquele consentido, uma vez que tais direitos seriam irrenunciáveis. Nesse contexto, ainda permaneceria incerto o alcance que se pode outorgar ao livre desenvolvimento da personalidade e à garantia fundamental à integridade física e moral, razão pela qual tal questão deve permanecer aberta ao debate social. 
No que se refere especificamente ao direito penal, entende o doutrinador que sua atuação frente a essa modalidade de intervenção no corpo humano - e, em particular, no cérebro - não parece justificada a curto prazo, haja vista a insuficiente determinação do bem jurídico a ser protegido de práticas daquela natureza. No momento atual, assinala, não parece tão evidente a afetação do princípio da ofensividade ou lesividade, de maneira que se revelaria adequado, no presente estágio dos debates em torno do assunto, a prevalência dos princípios da subsidiariedade e da ultima ratio. Assim, seria o bastante, por enquanto, a resposta penal que pode ser dada de lege lata, relacionada às intervenções cerebrais de melhora, aperfeiçoamento ou fortalecimento que produzam dano, dolosa ou culposamente, à vida ou à integridade física do afetado. Apenas nessas circunstâncias, identificado o bem jurídico ofendido, poder-se-ia analisar o papel legitimador do consentimento do interessado em face da intervenção levada a efeito por terceira pessoa.

Se, ao que parece, ainda há dúvidas acerca da legitimidade da intervenção cerebral direta para fins de "enhancement" - melhora, aperfeiçoamento ou fortalecimento - das funções mentais e intelectuais, muito mais questionamentos recaem, a nosso ver, sobre a utilização de procedimentos dessa espécie como resposta estatal ao crime, isto é, como forma de reabilitação do autor de um injusto penal, na busca de solucionar os problemas que o levaram ao cometimento do delito e, assim, evitar eventuais recidivas. Isso porquanto no primeiro caso se parte do pressuposto que o indivíduo submetido àquela prática tem autonomia de vontade, podendo escolher se confere ou não seu consentimento, ao passo que na segunda hipótese, ao menos se é buscada alguma efetividade da sanção penal do ponto de vista da prevenção especial, a decisão é unilateral, isto é, imposta pelo Estado $^{76}$.

76 A esse respeito, revela-se necessário fazer referência à interessante abordagem de Víctor Gabriel RODRíGUEZ (2014, pp. 298 a 300) acerca do que denomina "direito individual de recusar a cura". Para o professor de Ribeirão Preto, da aceitação pelo direito penal da existência de liberdade de vontade humana (expressa na estrutura de imputação penal) decorre que a intervenção cerebral, com a finalidade de reabilitação (prevenção especial), em um indivíduo que apresente potencial comportamento antinormativo é uma ofensa ao livre exercício da personalidade e, portanto, à dignidade da pessoa humana. A ideia, aqui, não é a de que a aplicação da cura de uma disfunção neurológica associada a um comportamento delituoso em determinado indivíduo significaria o desrespeito a uma liberdade constitucional - a qual poderia ser facilmente restrita como resposta estatal ao delito -, mas que uma intervenção cerebral de tal natureza representaria uma alteração (indevida) no próprio status de pessoa. Em outras palavras, a limitação à liberdade de enfrentar a norma - isto é, ao direito de se seguir a própria convicção, ainda que por isso se pague o preço estipulado pelo ordenamento -, por meio de um tratamento neurofarmacológico, por exemplo, constituiria uma intervenção na própria condição de pessoa, na medida em que retiraria do indivíduo a possibilidade de exercer sua personalidade, rompendo-se, assim, com o próprio fundamento da pena, ou seja, a noção de pessoa livre. RODRÍGUEZ observa que a destruição da personalidade - ou o impedimento físico de 
Há, além desse, outro problema que incide sobre a utilização da intervenção cerebral - aqui, tanto a direta (o "neuroenhancement"), quanto a indireta (tal qual a proposta de EAGLEMAN, o treinamento pré-frontal) - enquanto pena, voltada a reabilitação do infrator: trata-se do fato de tal modelo de punição fundamentar-se na ideia de que toda conduta criminosa necessariamente tem origem em alguma disfunção neuronal. Essa assunção, para além de carecer de mínima comprovação empírica, não é nem majoritária, muito menos consensual entre neurocientistas e juristas dedicados ao estudo do neurodireito, tratando-se de hipótese proposta por um grupo de pesquisadores - conforme detalhadamente abordado no começo deste capítulo -, lançada à discussão para a comunidade científica. Ocorre, todavia, que tal debate ainda se mostra muito restrito, incipiente, o que se reflete em pouquíssima produção acadêmica a respeito, tornando precipitada qualquer conclusão que se possa esboçar neste espaço acerca de sua legitimidade do ponto de vista do direito penal. Certo, somente, é que a aplicação de tal formulação na prática forense se mostra, em razão da parca análise doutrinária a respeito, absolutamente temerária.

De todo modo, é inquestionável que o desenvolvimento científico e tecnológico viabilizará o esclarecimento de dúvidas teóricas que hoje há no campo das neurociências, permitindo a consolidação de umas e a superação de outras concepções formadas a respeito do funcionamento do cérebro humano, possibilitando ao Direito, consequentemente, a construção de uma dogmática coerente com esses conhecimentos. Também fruto dessas contribuições futuras será uma ampliação dos debates na sociedade acerca das questões bioéticas envolvidas, além de um aprofundamento da discussão no meio acadêmico. Disso decorrerá a auspiciosa formulação de alguns parâmetros voltados ao estabelecimento de marcos regulatórios seguros acerca da legitimidade das intervenções cerebrais diretas e indiretas, quer para fins de melhora das funções cerebrais, quer para a reabilitação de infratores penais.

Até lá, com a certeza de que a proposta teórica ora analisada - de extinção da inimputabilidade da estrutura de responsabilização criminal e consequente edificação de um modelo de punição voltado à reabilitação do infrator por meio da neurociência (por se

seu exercício -, por meio da intervenção cerebral como potencial forma de punição estatal, é uma consequência que a neurociência ora nos apresenta como plausível, podendo desaguar em uma obstacularização do livre exercício da vontade. Segundo o autor, definir se essa alteração (compulsória) é ou não lícita (ou legítima) decorrerá do reconhecimento de um mínimo de valor individual kantiano, ou, ao reverso, do enaltecimento de um direito penal funcional e utilitário, orientado puramente às consequências, o qual provavelmente não se importaria com o tolhimento de uma personalidade livre que sequer é comprovada, em especial frente aos inequívocos benefícios que a "cura delinquencial" traria à sociedade. 
considerar que a conduta criminosa é causada por disfunções cerebrais) - ainda não está suficientemente estruturada a ponto de ser detidamente debatida pela doutrina penal (pois fundamenta-se em pressuposto extremamente inseguro), e assim ter analisada sua viabilidade dogmática, resta examinar se os conhecimentos neurocientíficos que se logrou atingir, com algum grau de confiabilidade, até o momento, representam ou não uma ameaça à culpabilidade.

\subsection{O futuro da atribuição de responsabilidade penal ante os aportes da neurociência}

\subsubsection{O fim da culpabilidade?}

Conforme se tem exposto neste trabalho, as pesquisas em neurociência - e, em especial, algumas interpretações dadas a seus resultados - têm suscitado uma série de questionamentos no direito penal, particularmente no âmbito da culpabilidade e de suas possíveis alternativas teóricas, em grande medida por conta de a estrutura de responsabilização criminal encontrar-se fundamentada na compreensão que o homem tem de si mesmo - enquanto ser dotado de racionalidade e consciência, que toma decisões com base em sua livre vontade -, a qual confronta-se com a perspectiva de ampla parcela dos neurocientistas, em sentido oposto, de que o livre-arbítrio constitui mera percepção subjetiva ilusória (DEMETRIO CRESPO, 2013 [2], pp. XVII e XVIII).

Nesse contexto, em que, de acordo com o viés neurodeterminista, o alternativismo subjacente ao conteúdo tradicional retribucionista da culpabilidade ("poder agir de outro modo") não só não pode ser demonstrado, mas que, ao contrário, é passível de comprovação de que não existe, o papel daquele elemento do crime na estrutura de responsabilização penal é colocado em xeque. Diante desse problema, uma série de penalistas tem se debruçado sobre a questão do futuro da culpabilidade na teoria do crime, especificamente buscando uma resposta para a seguinte pergunta: o conceito de culpabilidade é conciliável com os conhecimentos aportados pela neurociência?

Um dos estudiosos que mais tem se dedicado a esse assunto é o penalista espanhol Eduardo Demetrio CRESPo (2013 [1], pp. 38 e 39), que entre os anos de 2009 e 2012 liderou o projeto de pesquisa "Neurociencia y Derecho Penal: nuevas perspectivas en el 
ámbito de la culpablidad y tratamiento jurídico-penal de la peligrosidad", financiado pelo Ministério da Inovação e Ciência da Espanha. Para o autor, na atualidade, nem o indeterminismo calcado em um livre-arbítrio irrestrito, nem o neurodeterminismo mecanicista são sustentáveis, uma vez que o primeiro parte de um pressuposto metafísico que não se concilia com os conhecimentos aportados pelas ciências empíricas que estudam o comportamento, e o segundo apresenta uma imagem do ser humano à margem do ideal de liberdade, representando, em suas palavras, um retrocesso lamentável na evolução filosófica e política da modernidade, de maneira que qualquer desses extremos significaria uma impossibilidade absoluta de intercâmbio e comunicação entre neurociências e direito penal.

Nesse âmbito, sua proposta é de que neurociências e direito penal situem suas reflexões no ser humano, para que estejam à altura de seu tempo. Assim, uma compreensão pós-metafísica do direito penal exigiria não tomar o livre-arbítrio como fundamento do castigo, pois a experiência subjetiva de liberdade de vontade pelo ser humano resultaria insuficiente como critério para a heteroimputação jurídica. A esse respeito, a perspectiva de terceira pessoa resultaria não somente mais operativa, como também mais coerente com as demais ciências sociais. O doutrinador, então, formula uma solução conciliadora entre as ciências biológicas - em particular, as neurociências - e o direito penal sobre a base do que denomina um "compatibilismo humanista": "compatibilismo", porque parte da compatibilidade - ou possibilidade de entendimento - entre as ciências empíricas e o Direito $^{77}$; "humanista", pois repousa e encontra sua única razão de ser na dignidade do ser humano.

No que concerne à culpabilidade - e seu futuro na estrutura de responsabilização penal -, explica o professor de Toledo que a proposta do compatibilismo humanista gera duas consequências diretas - as quais, ressalta, são passíveis de revisão ulterior pela doutrina. A primeira é que, na hipótese de novos conhecimentos empíricos - obtidos por meio de novas tecnologias de neuroimageamento, por exemplo - demonstrarem que penas vêm sendo impostas em casos nos quais se passou a saber que a conduta delitiva é fruto de déficits cerebrais, tal dado deve ser tomado a favor do autor. Assim, destaca que é muito

\footnotetext{
${ }^{77}$ Também defende uma compreensão compatibilista do livre-arbítrio Juan Pablo MAÑALICH (2011,pp. 181 a 210). Para o autor, a neurobiologia não representa uma ameaça para a culpabilidade penal, pois a perspectiva materialista e reducionista apresentada a partir dos conhecimentos de tal disciplina se revela insuficiente para a compreensão de fenômenos complexos como a formação da vontade e a tomada de decisão. Em sua visão, a liberdade de vontade deve ser mantida como critério de atribuição de responsabilidade penal, desde que compreendida não como indeterminação, mas sim como autodeterminação do próprio comportamento.
} 
provável que o advento de novos conhecimentos neurocientíficos leve a uma ampliação dos casos de inimputabilidade e semi-imputabilidade. O segundo efeito é que qualquer medida que se possa adotar como alternativa ao castigo tradicional em todos os casos mencionados acima deve respeitar, sem exceções, os mesmos limites e garantias materiais e processuais que amparam os sujeitos considerados culpáveis no marco do Estado de Direito.

DEMETRIO CRESPO esclarece que o enfoque proposto parte de algumas ancoragens metodológicas, dentre as quais se incluem: o rechaço ao "silogismo retribucionista" - que situa o ônus da prova ao lado do determinismo e considera, portanto, justificada a pena em casos difíceis; uma concepção permeável não funcionalista da ciência penal; e a busca de respostas científicas unitárias (no sentido de não contraditórias entre si) frente a um mesmo objeto de conhecimento.

Diferentemente de DEMETRIO CRESPO, que busca uma aproximação entre neurociência e direito penal, Diego-Manuel LuZÓn PEÑA (2013, pp. 377 a 384) visa minimizar a influência que os resultados das pesquisas voltadas ao estudo do cérebro deve exercer sobre as teorias do crime e da pena. Retomando postulados do neokantismo e da filosofia dos valores, o autor enfatiza que o método das ciências naturais ("além da matemática, a experimentação física, química e de derivados biológicos, fisiológicos etc.") não é adequado para compreender os objetos de que se ocupam as "ciências do espírito", ou seja, as ciências humanas e sociais, para as quais deve-se levar em consideração peculiaridades humanas e sociais - entre outras coisas, valores, elementos de sentido e elementos normativos. Nesse sentido, sustenta que não se pode admitir, em absoluto, uma pretendida validez universal de experimentos, em suas palavras, "parciais" e "isolados" das neurociências acerca dos impulsos neuronais - especialmente quando realizados a partir de patologias ou de danos cerebrais. Da mesma maneira, defende que também não se pode admitir a validez das conclusões atingidas a partir daquelas pesquisas, vale dizer: $(i)$ de que apenas as camadas neurais profundas determinam o agir humano; (ii) de que esse é imposto por decisões tomadas por uma parte do cérebro (onde radicam a consciência e a vontade); e (iii) de que toda a percepção que os humanos têm de que, em situações normais, elegem e decidem consciente e voluntariamente não seria mais do que uma miragem, uma vã ilusão. 
Para o professor de Alcalá de Henares, essa perspectiva determinista retomada a partir da neurociência deve ser refutada porque não se encontra amparada em comprovações empíricas, mas na pretendida validade universal de uma lei natural - qual seja, a lei da causalidade ("todo efeito obedece a uma causa") -, que, aplicada à vontade humana, resultaria em que ninguém pode atuar de modo outro que não o realizado, por estar determinado por causas que não controla. De acordo com o doutrinador, embora impulsos e condicionantes prévios e atuais influenciem, de fato, o agir humano, esse conta também com um fator que não se verifica nos fenômenos naturais ou nos movimentos animais: a vontade racional, sustentáculo da liberdade de escolha e decisão, que também pode ser causa, e a causa decisiva e determinante do ato humano - seu efeito. Assim, os seres humanos, diferentemente dos outros animais e das forças da natureza, ao contarem com inteligência e razão - e terem, ademais, consciência moral (salvo em perturbações ou desviações graves) que os fazem valorar o significado dos atos como bons ou ruins desenvolveriam a capacidade de escapar da lei causal cega da natureza. Esses processos psíquicos (a inteligência, a percepção e a consciência dos valores; a vontade e a capacidade de controlar os impulsos e desejos e de escolher e decidir sobre a ação), inclusive, estariam pouco a pouco sendo desvendados pela neurociência, na medida em que vão se descobrindo as áreas e os mecanismos cerebrais a eles relacionados.

Tendo rejeitado a perspectiva determinista retomada a partir das pesquisas de neurociências, LUZÓN PEÑA enaltece a concepção normativa da culpabilidade - entendida como a reprovabilidade jurídico-penal individual do fato típico e antijurídico, em razão da possibilidade de atuação conforme ao Direito. Em sua compreensão, apesar das atuais contribuições oferecidas pelas ciências empíricas, o juízo de censura da culpabilidade normativa continua sendo a abordagem correta, em termos subjetivos, de responsabilização penal. Desse modo, argumenta que, mesmo diante dos aportes da neurociência, a estrutura da reprovabilidade jurídico-penal individual deve permanecer intacta, ou seja: baseada na liberdade de decisão e atuação do sujeito, em sua possibilidade de alcançar o conteúdo das normas e de determinar-se normalmente por elas, bem como na exigibilidade penal individual ancorada em valorações normativas que não tornem compreensível, justificável ou desculpável sua infração na situação concreta. Com relação à liberdade de vontade, assere que pode e deve partir das convicções sociais majoritárias, porquanto, em seu entendimento, têm uma indiscutível base racional e empírica, além de estarem refletidas nos valores e princípios básicos da Constituição e do Direito. 
Ainda mais crítico do que LUZÓN PEÑA à interferência da neurociência no Direito Penal, Winfried HASSEMER (2011, pp. 1 a 15), apesar de reconhecer que as discussões de biologia humana têm impacto evidente para a justiça penal, entende que o direito penal não pode depender de que as ciências empíricas atinjam consensos em torno de seus grandes objetos de estudo - dentre os quais, o livre-arbítrio - para ter seu arcabouço teórico estruturado. Para o autor, em outras palavras, a justiça penal tem metas cujo cumprimento não se pode postergar, vale dizer: dia a dia, deve-se decidir se alguém é imputável ou não, se atuou dolosa ou culposamente, se há atenuantes de personalidade em seu favor, não se podendo suspender os julgamentos até a conclusão da discussão em torno da liberdade de vontade - que pode durar décadas ou séculos. Assim, não seria o caso de dar por válido o determinismo advogado por alguns neurocientistas, mas sim de continuar a aplicar a estrutura de responsabilização penal vigente, que certifica a possibilidade de existência do livre-arbítrio e da culpabilidade.

Além disso, diante da tese propugnada por neurodeterministas, de que a tomada de decisão humana é efeito de processos neuronais inconscientes, e não de uma vontade livremente construída, o doutrinador sustenta que as ciências empíricas não são as únicas legitimadas a tratar do livre-arbítrio e, muito menos, a dar a última palavra a respeito. Em sua compreensão, há no campo da teoria do conhecimento e da ciência o que denomina um "erro categorial", derivado da vulneração do princípio segundo o qual toda ciência só observa aquilo a que seus instrumentos permitem acesso, e encontra uma resposta unicamente onde seu instrumental lhe permite uma pergunta que corresponda à resposta no plano categorial. Dito de outro modo, tal princípio expressa que aquilo que pertence ao instrumental de uma ciência fica determinado em função de seu objeto formal; se uma ciência atua fora do âmbito que lhe resulta acessível, confunde as coisas e as categorias e cria o caos.

Especificamente com relação à problemática ora abordada, em torno do livrearbítrio, o professor de Frankfurt assenta que as ciências de método empírico têm problemas peculiares com a concepção da liberdade, pois seus instrumentos não quadram com essa concepção: algumas delas seriam capazes de medir o reflexo da liberdade de vontade - como, por exemplo, as vivências de liberdade dos seres humanos -, mas o livrearbítrio enquanto objeto de investigação não lhes seria acessível - só receberiam uma informação mediata, tão somente a vislumbrando. Aqui, o erro categorial consistiria na 
suposição de que as ciências empíricas poderiam julgar cientificamente se outras ciências estão autorizadas ou não a desenvolver um conceito de liberdade - ou seja, a determinar se existe ou não livre-arbítrio. Tal suposição teria como pressuposto necessário afirmar a existência de uma hegemonia entre as ciências, algo que, segundo o penalista alemão, não há, assim como não existe um conceito geral de liberdade que flutue acima de todas as ciências. Pelo contrário, haveria a liberdade de toda ciência para determinar sua estrutura.

Nessa linha, HASSEMER afirma que a estrutura da ciência do direito penal é rica, bem ordenada e de provada valia - não estando submetida, irrestritamente, a postulados de outras ciências. Dessa maneira, no que tange à liberdade de vontade enquanto pressuposto da responsabilidade penal, não repousaria em conhecimentos da biologia humana, mas em razões sociais, consistentes, notadamente, no reconhecimento recíproco da liberdade de vontade entre as pessoas e na atribuição mútua, com base nela, de juízos morais na vida cotidiana. Tais razões, consoante o autor, não sobreviveram como alicerce da dogmática penal por ignorância e irracionalidade, mas por conhecimento e experiência ancorados profundamente na realidade das interações humanas em sociedade. E, diante dessa realidade, a culpabilidade desempenharia função crucial na estrutura de imputação jurídico-penal.

$\mathrm{Na}$ visão do doutrinador, a problemática a respeito do livre-arbítrio - e, especialmente, acerca do "poder agir de outro modo" - não representa um risco à culpabilidade, uma vez que esse elemento do delito está tratado de modo inteligente na lei penal alemã. Assim, argumenta que resulta decisivo que o $§ 20$ do $\mathrm{StGB}^{78}$ - e, seguindo seu critério, o $§ 21$ do $\mathrm{StGB}^{79}$ - não exija uma constatação da culpabilidade de um ser humano em um determinado caso concreto - e, desse modo, tampouco uma verificação da liberdade e da capacidade de agir de outro modo em uma determinada situação. Com efeito, o que tal dispositivo normativo exigiria é a ausência de perturbações que fundamentariam uma inimputabilidade, em um procedimento duplamente negativo. De acordo com o penalista, desse método - de aferição da culpabilidade por meio da exclusão das hipóteses de exculpação (negação da negação) - decorre uma consequência fundamental para práxis

\footnotetext{
78 "§ 20. Incapacidad de culpabilidad por perturbaciones psíquicas. Actúa sin culpabilidad quien en la comisión de un hecho es incapaz por una perturbación síquica patológica, por perturbación profunda de la conciencia o por debilidad mental o por otra alteración síquica grave de comprender lo injusto del hecho o actuar de acuerdo con esa comprensión." (ALEMANHA, 1999).

79 "§ 21. Capacidad de culpabilidad reducida. Si la capacidad del autor por las razones señaladas en el $\S 20$ esta considerablemente reducida en la comisión del hecho o para comprender lo injusto del hecho o para actuar de acuerdo con esa comprensión, entonces la pena puede ser disminuida conforme al $\S 49$ inciso $1 . "$ (AlEmanha, 1999).
} 
judicial: o juiz não fica obrigado a formular perguntas que não pode responder, a coletar dados que não pode encontrar e a valorar provas que não conhece, restando seu programa reduzido a suas possibilidades de conhecimento, em harmonia com elas - expressamente, se é observada no caso concreto alguma das causas de exclusão da culpabilidade descritas na lei.

HASSEMER assere, por fim, que o $§ 20$ do StGB, tratando das causas de exclusão da culpabilidade, também é a porta pela qual os conhecimentos consolidados das ciências empíricas do ser humano alcançam a aferição jurídico-penal da culpabilidade. Em outros termos, as categorias de exclusão da culpabilidade seriam as constelações nas quais o direito penal e as ciências empíricas entram em contato e penetram-se mutuamente estando, assim, abertas ao futuro. Seu estado atual, afirma o autor, é o resultado de evoluções de longo prazo nas ciências empíricas, mas também da decisão jurídico-penal sobre a relevância de tal aporte do desenvolvimento científico no modelo de atribuição de responsabilidade penal - e, especificamente, na culpabilidade. Nesse contexto, defende que o direito penal - sua ciência e sua práxis - nunca rechaçou in limine os conhecimentos das ciências naturais sobre o objeto "culpabilidade", mas, pelo contrário, sempre os reclamou e está obrigado a reclamá-los, se quiser manter a culpabilidade penal atualizada. E é nas causas de exclusão da culpabilidade (na lei penal alemã, o $§ 20$ do StGB) que os conhecimentos das biociências - e, em especial, das neurociências - considerados relevantes pelo direito penal encontrariam a abertura necessária para impactar a atribuição de responsabilidade criminal.

Com uma abordagem diferente dos autores anteriormente citados, Günther JAKOBS (2012, pp. 23 a 40) posiciona-se no sentido de que os aportes da neurociência não são incompatíveis com a ideia de responsabilidade penal. Segundo o autor, assim como para a moderna neurociência, para a teoria do direito penal os indivíduos humanos não são livres nem no plano físico (estão submetidos às leis naturais), nem no que diz respeito a seus impulsos vinculados à satisfação ou à insatisfação (estão sujeitos à influência constante de fatores internos e externos), de maneira que os resultados das pesquisas relacionadas ao estudo do cérebro pouco contribuiriam a esse respeito - as ideias deterministas não seriam novas, tendo já impactado o campo jurídico-penal.

A despeito dessa coincidência de perspectiva, a influência dos resultados das investigações da moderna neurociência seria limitada, pois uma sociedade normativamente 
estruturada não vincula meros indivíduos - seres humanos constituídos física e psiquicamente -, mas sim pessoas (naturais ou jurídicas), que são destinatárias de direitos e deveres construídos comunicativamente. Assim, a ordem normativa, o Direito, só é socialmente real na medida em que oferece uma orientação real às pessoas. Contudo, essa questão não estaria ao alcance das neurociências - restando-lhe oculta -, uma vez que seu objeto de estudo são os indivíduos, e não as relações sociais.

De acordo com o doutrinador, diferentemente do ponto de vista individual, do qual uma conduta conforme à norma nem sempre é preferível, as pessoas, enquanto detentoras de direitos e deveres, constituídas nos róis de obrigadas e autorizadas, são responsáveis por procurar uma motivação de fidelidade ao Direito. Assim, para não comportar-se de forma perturbadora em sociedade, a pessoa tem que estar informada tanto de dados naturais (leis elementares da lógica, da matemática, da física etc.), quanto de dados sociais e institucionais (por exemplo, o que significa causar uma lesão, e quais são as consequências desse ato). Esse saldo informativo - existente ou alcançável - não necessita de ênfase penal alguma para manter-se no nível necessário, uma vez que disso cada pessoa, por seu próprio interesse, deve se ocupar.

Nesse sentido, com a ordem social atingida por meio do comportamento fiel ao Direito por parte das pessoas, passaria a ser-lhes assegurada institucionalmente uma liberdade de autoadministração, uma autonomia de organização com relação aos próprios direitos, isenta de perturbações externas. A fidelidade normativa, então, revelar-se-ia como a contrapartida prestada pelas pessoas à sociedade em troca da garantia à não intervenção alheia. Dessa liberdade de ação nasceria a responsabilidade pelas consequências: quem não obedece ao dever de ser fiel ao Direito arroga algo à custa dos outros, gerando uma pretensão da sociedade - representada pelo Estado - de compensação do dano causado.

JAKOBS explica que na medida em que a responsabilidade no moderno direito penal da culpabilidade se vincula à falta de fidelidade jurídica - isto é, à falta de vontade de cumprimento do Direito -, passou-se a falar habitualmente em "culpabilidade pela vontade", "defeitos da vontade" e outros termos do gênero, estendendo-se tais referências até a expressão "livre formação da vontade" - ou livre-arbítrio. Nesse contexto, ressalta que é necessário aclarar que esse vocábulo, desde uma perspectiva do direito penal, não se refere ao indivíduo (que é causalmente determinado), mas sim à pessoa - ou, mais precisamente, ao destinatário das expectativas normativas. Desse modo, assinala que, no que diz respeito à estrutura de atribuição de responsabilidade penal, o livre-arbítrio não é 
algo positivamente pressuposto, mas, na verdade, constitui uma metáfora da ausência de coação "fora do comum" (erro invencível, doença mental, estado de necessidade exculpante).

De acordo com o professor de Bonn, uma pessoa é responsável pela suficiente fidelidade ao Direito. Quanto a essa relação "hermético-normativa", argumenta que prescinde da existência livre-arbítrio (aqui, no sentido usual do termo), bem como que não é alterada pela causalidade física das atividade cerebrais, nem pelas determinações psíquicas orientadas por satisfação e insatisfação: resulta irrelevante se a pessoa poderia ter agido de outra maneira, importando tão somente se o resultado dos fatos pode ser interpretado como atribuível a ela. O livre-arbítrio, nesse Direito em que a pessoa é concebida como destinatária da obrigação de fidelidade à norma, não deve ser assumido como algo além de uma analogia de que a vontade - e tão somente vontade - serve de orientação, ainda que não como algo natural, mas sim como uma construção normativa.

Afirma o penalista que a orientação normativa só ascende à realidade quando os indivíduos conformam-se à situação posta. Uma dessas conformações, em sua concepção, é a "sensação" de responsabilidade, com relação à qual há uma suposição, no campo do direito penal, de que deriva de uma compreensão da própria personalidade, produzida no marco de um processo de aprendizagem condicionado socialmente. Essa hipótese, segundo o autor, seria compatível com os resultados das pesquisas de neurociências. Com efeito, a socialização do processo de imputação às pessoas seria confirmado pelas mais recentes investigações neurológicas, segundo as quais o sentimento da autoria de nossas ações seria, juntamente com o resultado de uma associação, uma consequência da atribuição por meio das relações sociais, constituindo, provavelmente, o "eu infantil" como sujeito de ação, principalmente por meio de referida atribuição (ROTH, 2003, p. 517). Em outras palavras: o indivíduo infantil chegaria a acordos com sua incipiente personalidade, compreendendo-se a si próprio como pessoa, de maneira que é essa dupla alma em seu peito que possibilitaria conceber o esquema passional de satisfação e de insatisfação a partir de estímulos externos (de forma bastante literal), ao qual deve responder de acordo com sua concreta configuração; desse modo, surgiria o "eu" como pessoa autoconsciente.

Em suma, para JAKOBS o estudo do cérebro não representa uma ameaça à culpabilidade, porque os conhecimentos dele derivados seriam compatíveis com a noção de pessoa para o Direito, a partir da qual é construída - e justificada - a responsabilidade penal. Com efeito, as pesquisas em neurociência do comportamento reforçariam a 
concepção jurídico-penal de que a compreensão da própria personalidade, a ideia de que somos os autores de nossas próprias ações, é produzida no marco de um processo de aprendizagem socialmente condicionado. Os postulados neurocientíficos, assim, contribuiriam para reforçar a correspondência entre autonomia (liberdade de autoadministração, isenta de influências alheias) e responsabilidade, mas não entre livrearbítrio e responsabilidade. Depreende-se da concepção do penalista alemão, destarte, que neurociência e culpabilidade não combinariam tão somente no caso de se considerar o conceito finalista (em vez da concepção jakobsiana) desse elemento do delito, a qual é firmemente ancorada na ideia de liberdade de vontade.

Cada qual dos autores tratados neste capítulo apresenta, a partir de aprofundados trabalhos, uma abordagem própria acerca da questão da intersecção entre a neurociência e o direito penal. Não obstante, tanto os que buscam uma aproximação entre esses dois campos do conhecimento (DEMÉTRIO CRESPO e JAKOBS), quanto aqueles que são mais cautelosos com relação às possíveis influências do primeiro sobre segundo (LUZÓN PEÑA e HASSEMER) têm por traço comum de suas propostas teóricas a manutenção da culpabilidade na estrutura de responsabilização penal - ainda que varie, entre os doutrinadores, as concepções a respeito do conteúdo material daquele elemento do delito. Além disso, os penalistas, dentre os citados, que de alguma forma criticam o impacto da neurociência no direito penal não a rejeitam absolutamente, mas tão somente criticam a visão determinista retomada a partir de algumas pesquisas de investigação do cérebro.

Dessas constatações, parece-nos que, a despeito da crise da concepção normativa da culpabilidade e do amplo e irresolvido debate em torno de sua função no âmbito da imputação jurídico-penal, a doutrina recusa, quase que unanimemente, a supressão daquele elemento do modelo de responsabilização penal. Com relação aos aportes da neurociência do comportamento ao direito penal, apesar de majoritariamente se enjeitar a perspectiva determinista retomada a partir de resultados obtidos em alguns experimentos naquela área, essa repulsa não se estende indiscriminadamente a todas as contribuições oriundas de pesquisas sobre o funcionamento do sistema nervoso central: não há oposição, por exemplo, com relação aos impactos das biociências nas causas de exclusão da culpabilidade, notadamente na aferição da imputabilidade do autor de um injusto penal.

Conquanto sejam fascinantes as projeções da neurociência cognitiva - vale dizer, demonstrar objetivamente, por meio de leitura da atividade cerebral em tempo real, como a 
vontade foi formada, conduzindo o processo da tomada de decisão e resultando na realização da ação -, os resultados de suas pesquisas, como já se observou, ainda são muito incipientes, seja porque as técnicas utilizadas são relativamente rudimentares, seja porquanto muitas das experiências levadas a efeito são direcionadas, pretendendo substituir uma situação real de resposta livre por conjunturas construídas em um ambiente controlado. Nesse contexto, isto é, no atual estágio de seu desenvolvimento, pode-se concluir, tranquilamente, que o advento da neurociência não representa o fím da culpabilidade. Resta saber, todavia, que natureza de seu conteúdo material prevalecerá na doutrina penal: a retribucionista - baseada na possibilidade de se agir de modo diverso; ou a preventiva - ancorada na acessibilidade à norma ou na capacidade de motivação por essa. As pesquisas de neurociência em torno do comportamento violento e da perigosidade podem oferecer contribuições decisivas a esse debate.

5.3.2. Comportamento violento e perigosidade: fiéis da balança na emergência de um modelo preventivo de responsabilização penal?

A violência é, inquestionavelmente, um dos principais problemas de nossa sociedade. Não obstante, as condições de sua gênese são tão controvertidas quanto a questão do tratamento jurídico-penal adequado aos delinquentes violentos - isto é, quais são as medidas idôneas para sua ressocialização e para a evitação de comportamentos violentos em geral. Em uma discussão dessa natureza, tem papel central a culpabilidade jurídico-penal e a fundamentação da pena dos autores de crimes violentos, notadamente no que tange às finalidades da punição em infratores perigosos: se de caráter retributivo, preventivo ou misto.

Nesse âmbito, o neurocientista alemão Gerhard Rотн (2013, pp. 669 a 690) afirma que, diante da insuficiência geral da concepção tradicional do livre-arbítrio - tanto de uma perspectiva filosófica, quanto do ponto de vista psicológico-neurobiológico -, refletida na ausência de posições seguras a respeito do tema, ainda muito divergente entre os estudiosos mesmo depois de séculos de debates, se mostra premente a renúncia ao conteúdo material da culpabilidade normativa, vale dizer, ao "poder agir de outro modo". Para o autor, caso se deseje evitar que a responsabilidade penal esteja ancorada em pressuposto fictício, resulta necessário examinar os conhecimentos empíricos favoráveis e 
contrários a um conceito alternativo de culpabilidade, qual seja, a culpabilidade pela personalidade (ou pelo caráter) - conceito recentemente retomado na Alemanha -, em que a reprovabilidade é voltada às escolhas de vida que levaram o agente a comportar-se contra a norma, isto é, a seus déficits de personalidade, o que inclui sua constituição genética.

Buscando analisar cientificamente a viabilidade da concepção da culpabilidade pelo caráter, o pesquisador volta suas atenções aos denominados "autores intensivos" - ou seja, indivíduos violentos reincidentes -, pois, segundo sua justificativa, somente a respeito desses existem dados estatísticos suficientes, além de que, paralelamente à reprovabilidade intensa em razão da gravidade dos delitos perpetrados, mostra-se recorrente naqueles (vale dizer, com maior frequência do que nos autores de crimes não violentos) a concorrência de causas de atenuação e de exclusão da culpabilidade. Diante desse quadro, o autor visa examinar, desde conhecimentos em psicologia e neurociência, qual das duas explicações possíveis para o comportamento violento é a (mais) acertada: (i) os "autores intensivos" são seres humanos especialmente malvados, que decidem de modo reiterado, livre e conscientemente, a favor de seus atos e contra sua consciência jurídica, sendo capazes, portanto, de culpabilidade jurídico-penal; e (ii) os "autores intensivos" devem ser considerados doentes mentais em face de uma combinação de influxos genéticos derivados do desenvolvimento cerebral -, de traumas na primeira infância e de influências negativas do ambiente, a qual geralmente tem efeito antes de atingirem catorze anos de idade - época em que o ser humano ainda é incapaz de culpabilidade -, de maneira que, para o direito penal, são inimputáveis ou apresentam uma culpabilidade diminuída.

Em amplo e aprofundado trabalho de revisão bibliográfica, ROTH notou que os conhecimentos acerca do funcionamento do cérebro humano colocam em xeque não somente a noção tradicional de livre-arbítrio, como também as bases sobre as quais se assenta a culpabilidade pelo caráter ou pela condução da própria vida. A esse respeito, observa o autor que tanto os autores violentos reativos-impulsivos, como os pró-ativospsicopatas manifestam sua disposição a comportamentos violentos - e demais modalidades de condutas antissociais que resultam relevantes para o diagnóstico - já aos treze anos de idade - e até mesmo antes, muitas vezes. Em um período da vida, portanto, em que a capacidade de discernimento não está amadurecida, e que são considerados inimputáveis do ponto de vista do direito penal. Com efeito, para poder ter influência sobre o desenvolvimento de sua própria personalidade - e, assim, poder ser considerado responsável por ela -, um ser humano deveria estar em condições, em alguns casos já na 
primeira infância, de sair de seu próprio processo de amadurecimento para supervisioná-lo e, dessa forma, corrigi-lo quando necessário - o que, nas palavras do neurocientista, se mostra "uma ideia absurda, sem dúvida".

De acordo com o professor de Bremen, desde a perspectiva da psicologia e das neurociências, o processo de desenvolvimento de uma criança não está, de qualquer modo, predeterminado desde o princípio, razão pela qual os conhecimentos acima expostos não devem ser confundidos com um biologismo criminal, para o qual a origem do comportamento desviado estaria na disposição genética do indivíduo. Em verdade, ressalta, ao menos a fase da infância é extraordinariamente plástica, isto é, suscetível de ser formada por meio de influências do ambiente, no que se inclui a educação e as próprias experiências, de maneira que a sociedade se revela como um fator codeterminante da configuração de condutas não desejadas nos indivíduos que a compõem. Tal plasticidade infantil, contudo, resta significativamente reduzida desde muito cedo em certos casos, em virtude de uma predisposição genética somada a danos pré-natais e pós-natais ou a traumas psíquicos, constituindo uma parte do problema da violência. Nessa linha, segundo o pesquisador, a psicologia mostra que as disfunções evolutivas apresentariam um nível maior de dificuldade para sua correção proporcional ao grau de precocidade de sua manifestação, de modo que, nos "autores intensivos", o que se nota é um decurso de modalidades problemáticas desde a infância, com os primeiros comportamentos abertamente agressivos, passando pela adolescência, até a idade adulta, já com as condutas violentas e criminosas.

Com base nesses dados, RоTH conclui que, desde o ponto de vista da psicologia e das neurociências, se apresenta como inevitável uma renúncia radical ao princípio da culpabilidade em sentido clássico - vale dizer, enquanto reprovabilidade, independentemente se fundamentada filosoficamente, empiricamente ou normativamente. De acordo com o autor, é possível inferir, com lastro nos conhecimentos daquelas disciplinas, que quanto maior é a gravidade do fato em suas consequências e sua percepção social, maior é a nitidez com que se revela que seu autor apresenta perturbações genéticas, orgânicas e psíquicas. Assim, em sua visão, não há alternativa senão recorrer a um direito penal puramente preventivo, da mesma maneira que não há opção coerente senão abdicar das penas que não contemplem medidas de apoio.

Segundo o neurocientista, diante desse quadro, um dilema se apresenta: a pena tradicional, enquanto instrumento pedagógico de reabilitação, deve ser rechaçada; por 
outro lado, todavia, não se pode declinar da ameaça de pena, já que comprovada sua eficácia em dissuadir grande parte dos potenciais delinquentes - concretamente, aqueles mais "acessíveis normativamente". Em sua compreensão, a única possibilidade existente de resolução dessa questão, também compatível com a garantia fundamental à dignidade humana, seria, nas hipóteses de delitos graves, uma privação de liberdade combinada com treinamentos ou terapias, ou, nos casos menos graves, medidas "dolorosas" alternativas ao encarceramento, como, por exemplo, sanções pecuniárias e restritivas de direitos. Destaca o neurocientista, contudo, que para que tais respostas estatais possam atingir seus objetivos, alguns desafios fundamentais ainda precisariam ser enfrentados, a saber: (a) um melhor diagnóstico a respeito das diversas classes de autores violentos; (b) uma investigação acerca das causas que, orientada com base no diagnóstico, avance nos planos neurocientífico-psicológico e sociopsicológico; e (c) partindo do anterior, o desenvolvimento de métodos de prevenção, de treinamento e de terapia, e sua avaliação rigorosa. Se encarados esses desafios desde já, pontua, não há dúvidas que o trabalho realizado renderia frutos no marco de uma década.

Mais céticos do que Roth, os neurocientistas ingleses Colin CAMPBELL e Nigel EASTMAN (2012, pp. 139 a 152), tendo estudado o alcance de estudos científicos que utilizaram tecnologia de imageamento para examinar estruturas e funções cerebrais de grupos de indivíduos classificados como "antissociais", apontam a extrema dificuldade em se extrapolar, dessas pesquisas, quaisquer fatos que seriam relevantes no que se refere ao estado mental de um sujeito "antissocial" acusado criminalmente, especificamente com relação ao injusto penal supostamente praticado em suas particulares circunstâncias.

De acordo com os autores, a violência e a agressividade têm sido examinadas nos últimos anos por meio de uma ampla gama de métodos neurocientíficos - incluindo-se aí a neuroendocrinologia, a eletrofisiologia, o neuroimageamento e a genética comportamental -, em muitos casos produzindo resultados convergentes através de diferentes abordagens e, assim, apresentando animadora validação científica cruzada. Nesse sentido, tal desenvolvimento não passou despercebido pelo sistema de justiça criminal, nem pelos formuladores de políticas públicas, especialmente no que diz respeito aos estudos acerca do comportamento antissocial, realizados por meio de neuroimageamento estrutural e funcional. 
Tomados conjuntamente, os resultados de investigações realizadas a partir de neuroimageamento estrutural e funcional fornecem, segundo os pesquisadores, algumas indicações de alterações cerebrais associadas a uma gama de comportamentos antissociais. Nessa linha, por exemplo, têm se mostrado consistentes as conclusões alcançadas em pesquisas relativas à região cerebral do córtex pré-frontal, nas quais anormalidades estruturais e funcionais têm sido relacionadas a duas sub-regiões - córtex pré-frontal dorsolateral ("dorsolateral prefrontal cortex" - DLPFC) e córtex orbitofrontal ("orbitofrontal cortex" - OFC) - associadas a funções sabidamente prejudicadas em populações antissociais: a primeira atrelada à persistência de respostas e ao mau planejamento e organização; e a segunda ligada à fragilidade no controle inibitório, à tomada decisão emocional e ao processamento de recompensas. A despeito desses resultados promissores, os neurocientistas mostram-se relutantes em transladá-los ao campo do direito penal.

Conquanto reconheçam que muitos dos processos cognitivos envolvidos em comportamentos antissociais são potencialmente relevantes para questões jurídico-penais, como o dolo ("intent") e a culpabilidade ("responsibility"), CAMPBELL e EASTMAN asserem que os estudos envolvendo neuroimageamento possuem limitações metodológicas, o que traz perigos à sua utilização no sistema de justiça penal. Nessa direção, argumentam que a literatura neurocientífica relacionada ao comportamento antissocial apresenta resultados que, apesar de por vezes animadores, estão longe de ser conclusivos, em parte em razão da falta de replicação das pesquisas, imprescindível para tornar seguras as descobertas, em parte devido ao pequeno tamanho de grupos amostrais e de controle dos estudos, o que limita sua força estatística na detecção de diferenças reais existentes nas populações antissociais. Além disso, complementam, as investigações por meio do neuroimageamento apoiam-se em uma comparação estatística entre a imagem experimental e um modelo utilizado para definir o "normal". Contudo, a noção de tal modelo seria problemática em si e por si só, vez que não há padrões de referência ("gold standards") e tampouco um consenso a respeito de qual medida deve ser utilizada para balizá-los. O resultado disso é que qualquer cérebro apresentado pode ser qualificado como normal em uma medição e como estatisticamente anormal em outra avaliação, muito embora essa última possa ser considerada tão válida quanto a primeira.

Com relação à utilização de pesquisas dessa natureza como prova no processo penal, os autores apontam ainda outros convenientes. Primeiramente, os métodos de estudo 
com neuroimageamento são, na maioria das vezes, desenvolvidos e validados apenas para uso experimental, de maneira que podem não ser admitidos como prova se aplicados em situações reais, isto é, não experimentais. Em segundo lugar, as imagens produzidas em momentos e circunstâncias diferentes podem ter relevância limitada em questionamentos acerca de ações ou estados passados - como, por exemplo: "tinha o autor, ao tempo do fato, consciência acerca da conjuntura em que estava envolvido?" -, por terem sido geradas em contextos específicos e, portanto, não serem generalizáveis. E, por fim, não há evidências científicas de que os resultados neurocientíficos relacionados ao comportamento antissocial possuem qualquer validade preditiva, de modo que existe o perigo de que os procedimentos de leitura cerebral atualmente realizados possam ser (erroneamente) utilizados para inferir um risco para o (indefinido e desconhecido) futuro. Esse ponto, especificamente, já tornaria altamente questionável o uso daquela técnica para subsidiar argumentações a favor da finalidade preventivo-especial da pena.

Diante desse quadro, os neurocientistas ingleses, antes de tecerem suas conclusões, regressam ao médico italiano Cesare LOMBROSO, que séculos atrás valeu-se da frenologia para explicar e prever a atividade criminosa, inferindo certas espécies de comportamento a partir de determinados contornos cranianos ${ }^{80}$. Desde essa época, explicam, os médicos têm lutado cientificamente para traçar critérios seguros a respeito das causas do comportamento violento, buscando identificar as hipóteses em que esse pode ser atribuído a condições patológicas. Nesse campo, em que ainda paira a incerteza, aspectos da moderna neurobiologia parecem, de forma tentadora, oferecer respostas definitivas. Contudo, na visão dos autores, a ausência de boa ciência dura (ciências naturais de base empírica) exige extrema cautela contra o uso indevido dos conhecimentos científicos para fins jurídicos ou políticos. E os resultados emergentes da neurociência trariam, concomitantemente com o risco de realização dos propósitos científicos, os perigos advindos de certas agendas do

\footnotetext{
${ }^{80}$ Esse trecho da principal obra de LOMBRoso (2007, pp. 196 a 198), "L'uomo delinquente" (ou "O homem delinquente"), é elucidativo de sua teoria: "É frequentemente geral o acordo de não admitir nos dementes morais a grande frequência das anomalias cranianas e fisionômicas que vemos caracterizadas muitas vezes no réu nato. Antes Morel, depois Legrand de Saulle e agora Krafft-Ebbing apontam a frequência em macrocéfalos de cristas ósseas do crânio, de crânios muito alongados ou muito arredondados, e a desproporção entre as duas metades da face, [além de] lábios volumosos, boca grande, dentes mal conformados com precoce caída nas formas mais graves (...). Todas anomalias, especialmente as do crânio, que temos encontrado nos criminosos. (...) § A fisionomia dos famosos delinquentes reproduziria quase todos os caracteres do homem criminoso: mandíbulas volumosas, assimetria facial, orelhas desiguais, falta de barba nos homens, fisionomia viril nas mulheres, ângulo facial baixo". A propósito, para o autor da Escola Clássica, nos "dementes morais" e nos "delinquentes natos" - diferentemente das "pessoas sãs" - a vontade não é livre, de maneira que a conduta criminosa deriva de uma "força irresistível" que lhes é inerente, a qual pode decorrer de uma "pervertida afetividade", de um "ódio excessivo e sem causa" ou da "insuficiência de freios" (LOMBROSO, 2007, pp. 217 a 223).
} 
Direito e da política. Para CAMPBEll e EASTMAN, LOMBroso possivelmente conquistou credibilidade à sua época em razão da simplicidade bela das respostas que ofereceu, mas tal crédito, com o tempo, se revelou infundado. Dessa experiência histórica, sustentam, devemos extrair as lições pertinentes, não nos deixando seduzir por uma solução lombrosiana moderna - uma frenologia interna, em vez de externa -, a qual quase que certamente realiza profunda injustiça com natureza rica da condição humana, violando, potencialmente, os direitos fundamentais de cariz constitucional.

A indefinição exposta acima, entre os próprios neurocientistas, acerca da influência que os aportes do estudo do cérebro acerca da perigosidade e do comportamento devem exercer no direito penal e, especificamente, na culpabilidade, também se reflete entre os penalistas. Com efeito, se é certo que a doutrina majoritariamente defende manutenção da culpabilidade no modelo de responsabilização penal, também não há dúvidas de que, quanto ao conteúdo material desse elemento do delito (se de natureza retributiva ou preventiva), persiste entre os autores a incerteza.

Em consonância com o entendimento do neurocientista Gerhard RoTH, Manuel CANCIO Meliá (2013, pp. 529 a 545) propugna um direito penal voltado à finalidade preventiva da pena. Em verdade, afirma o autor compartilhar com a ampla maioria dos penalistas a conclusão de que, considerando o rico debate histórico sobre os fins da pena, as descobertas da neurociência não devem afetar os pilares essenciais do direito penal e, particularmente, tampouco devem suprimir os fundamentos do conceito de culpabilidade. Contudo, esclarece, partilha desse diagnóstico desde uma perspectiva distinta da maior parte dos doutrinadores, por entender que não é necessário ingressar em um novo capítulo da já milenar discussão sobre o livre-arbítrio, uma vez que esse debate não seria próprio de um sistema social, como é o direito penal. Expressamente, assinala que do ponto de vista do conceito funcional da culpabilidade - desenvolvido por JAKOBS -, sua fundamentação na prevenção geral positiva é imune às dúvidas semeadas pela neurociência em torno da liberdade de vontade do ser humano.

De acordo com o professor de Madri, o sistema penal é uma instituição social, razão pela qual aquilo que não alcance esse plano se lhe revela simplesmente irrelevante. Dito de outro modo: se o conceito de culpabilidade é determinado pelas necessidades de prevenção geral positiva, mostra-se sem importância que se descubra que todos os seres 
humanos estão plenamente determinados por processos neuronais inconscientes - ou por outros fatores -, já que isso não alterará, de qualquer modo, as necessidades de controle social, ao descrever um fenômeno onipresente no ambiente. Para o doutrinador, a despeito de não representarem uma ameaça de abolição da culpabilidade, isso não significa que os avanços no conhecimento do funcionamento do cérebro humano resultam irrelevantes para aquele conceito jurídico-penal. Nesse sentido, por exemplo, os novos conhecimentos neurocientíficos acerca das bases físicas da psicopatia permitiram afirmar a possibilidade de que determinadas formas dessa condição eliminem a imputabilidade, afastando, portanto, a culpabilidade.

Na linha da compreensão de RoTH, CANCIO MELIÁ entende que a neurociência possibilita que, em muitos casos, como nas hipóteses de psicopatia, haja uma mudança acerca da visão que se tem de alguns autores de injustos penais: de "malvados" ("bad"), passariam a ser considerados "doentes psíquicos" ("mad"). No que diz respeito aos psicopatas, por exemplo, já haveria larga bibliografia em psicologia sustentando que se tratam de agentes irracionais, devido a sua incapacidade de criar empatia e de interiorizar valores, pelo que não seria possível formular-lhes um juízo de reprovação moral. Conhecidas as bases neurofisiológicas da psicopatia, a tornar mais confiável o diagnóstico da doença, do ponto de vista jurídico-penal o caminho seria o mesmo: o da impossibilidade de responsabilização.

O penalista espanhol assinala que essa conclusão se justifica no contexto de um conceito funcional de culpabilidade, no qual esse elemento do delito deriva das necessidades de prevenção geral positiva, e significa que a explicação da transgressão da norma é atribuída ao infrator em razão da ausência de uma explicação alternativa. Nesse âmbito, a consequência do comportamento contrário ao Direito é a imposição de uma pena a seu autor, como mecanismo de estabilização contrafática da norma. Assim, partindo-se do conceito jakobsiano da culpabilidade, essa fica definida pela missão que cumpre, qual seja: identificar a motivação defeituosa do agente como a razão do conflito. Sua falta de assunção do ordenamento é o que explica a existência da quebra das expectativas normativas. Depende da constituição da sociedade, contudo, definir quando aquilo ocorre e quando o autor, por outro lado, pode distanciar-se da norma -, bem ainda quais são os fatores de responsabilidade do autor - e quais não o são.

Em uma sociedade como a nossa, afirma o professor de Madri, invadida pela imagem de mundo gerada pelas ciências naturais, não se pode ser indiferente a um novo 
conhecimento acerca do funcionamento do cérebro, assim como não poderia sê-lo descobertas relacionadas às leis da física em geral - como, por exemplo, se eventualmente viesse a ser identificado que as ondas eletromagnéticas, provenientes, v. g., de antenas telefônicas, causam lesão à saúde. Nesse contexto social, argumenta, mostra-se necessário um acoplamento estrutural entre os sistemas da ciência e do Direito, o que significa uma abertura a eventuais alterações de compreensão a respeito de alguns dogmas - incluindo-se, aí, a visão acerca de determinadas condições mentais, como a psicopatia. Dessa maneira, com as contribuições da neurociência, parece claro, para o penalista espanhol, que aqueles que padecem de psicopatia distanciam-se de certa maneira de suas condutas, na medida que essas são atribuíveis a sua falta de capacidade de perceber a infração à norma diferentemente dos demais indivíduos. Uma vez considerados os psicopatas inimputáveis, restaria, a partir de um vasto campo de trabalho interdisciplinar - incluída, aqui, a neurociência -, estabelecer os parâmetros de definição do grau de perigosidade do sujeito acometido por essa doença, além das características, dentre elas a duração, das medidas a que estaria submetido.

No polo inverso do debate, Mercedes PÉREZ MANZANo (2011, pp. 1 a 39) assenta que a opção por uma fundamentação preventiva ou retributiva - ou mista - da culpabilidade não deve ser realizada levando em consideração somente os déficits científicos de que padecem as teorias retributivas, derivados, notadamente, de sua vinculação com o livrearbítrio: é necessária nessa análise, também, que se tenha em conta duas outras questões. De um lado, há que se submeter as teorias preventivas ao mesmo escrutínio científico imposto às retributivas. De outro, ambas as teorias devem ser examinadas desde uma perspectiva valorativa, uma vez que a escolha de uma ou de outra fundamentação não depende apenas de sua racionalidade científica no âmbito do direito penal, mas também de sua legitimidade em um Estado Constitucional de Direito.

Desde essas bases, a autora sustenta que nem a prevenção geral de intimidação, nem a prevenção especial, tomadas como fins exclusivos da pena, são capazes de realizar uma fundamentação legítima do direito penal, necessitando-se, para tanto, em certa e diversa medida, recorrer às fundamentações retributivas. Com relação às teorias da prevenção geral, precisariam se valer da retribuição para: (i) justificar a pena frente ao sujeito ao qual é imposta; e (ii) como requisito de sua própria eficácia funcional. No que se refere às teorias da prevenção especial, necessitariam da retribuição para não extrapolarem 
os limites derivados dos princípios da ofensividade (ou lesividade; "principio del hecho") e da legalidade, inerentes ao Estado de Direito.

De acordo com a doutrinadora, um direito penal preventivo geral apresenta um déficit de legitimação frente o indivíduo a quem se impõe a pena, uma vez que essa resposta estatal ao delito é dada tão somente por gerar benefícios sociais - isto é, a evitação de novos crimes -, de maneira que a questão que se coloca é: se os benefícios sociais são gerais, por que não se reparte o custo da solução do conflito social também de forma geral? Em sua compreensão, o direito penal, ao impor sanções a um cidadão, não pode justificálas apenas de forma utilitarista (ou preventiva), exigindo-se, além disso, uma legitimação distributiva, vale dizer, uma justificação de por que somente um membro da sociedade arcará com o citado custo da solução do conflito social. Assim, um direito penal legítimo seria aquele que está em condições de explicar à sociedade e ao condenado as razões pelas quais a pena está sendo imposta. Contudo, a atribuição de uma finalidade preventivo geral à pena não conseguiria refutar a crítica de instrumentalização do cidadão nos interesses da coletividade, a qual acarreta a restrição de direitos de um indivíduo voltada ao alcance de um benefício da generalidade. Tal instrumentalização, na análise da autora, é frontalmente contrária à dignidade humana, que exige tratar o ser humano como um fim em si mesmo e constitui núcleo essencial do acervo valorativo constitucional.

Além disso, PÉREZ MANZANO entende que a prevenção geral de intimidação parte de um modelo de pessoa em que essa não é considerada um ente racional e moral, que se convence por meio do exercício da razão, mas como um ser que se controla coativamente, da mesma maneira como se adestra os animais domésticos e se treina bichos de circo. Essa imagem do sujeito destinatário da reação penal, argumenta, não se coaduna com nosso modelo de sociedade e com nosso ordenamento constitucional, para os quais os indivíduos são dotados de dignidade e de autonomia - pessoal e moral -, desenvolvendo sua personalidade livremente. Nesse contexto de legitimação da pena frente ao cidadão ao qual é imposta é que a finalidade retributiva cumpriria seu papel, aportando à sanção penal a justificação de que a resolução do conflito social criado com o delito se resolve com a atribuição de uma punição a seu autor: os custos da pacificação devem ser pagos por aquele que contribuiu com a criação do próprio conflito de forma culpável e na medida de sua responsabilidade. Desse modo, a punição (restrição de bens ou de direitos) só é justa quando imposta a quem voluntariamente, em condições normais de compreensão da norma e de autodomínio da própria conduta, pratica o injusto penal. A culpabilidade, então, 
enquanto reprovabilidade - com carga retributiva, portanto -, aporta a legitimação interna (frente ao sancionado) de que necessita o direito penal, de maneira que a renúncia à retribuição representaria um déficit de legitimidade da intervenção penal.

Para a professora de Madri, tampouco a prevenção especial seria uma opção válida e legítima de fundamentação do direito penal. Levando em consideração que um setor relevante das neurociências tem defendido medidas preventivo especiais de tratamento terapêutico de natureza neurológica - conforme aqui exposto no item "5.2. A hipótese da transgressão penal enquanto indício de anormalidade cerebral (...)", acima -, a doutrinadora apresenta as razões pelas quais julga inadequados modelos desse jaez de resposta estatal ao delito. Em primeiro lugar, assere que um direito penal baseado em juízos de periculosidade tem muito mais déficits empíricos do que um lastreado no livrearbítrio, porquanto ainda que se aceite que o agir humano é determinado, isso não implica que se está em condições de conhecer, na atualidade, todos os fatores de causam o cometimento do delito - e como esses operam -, de modo que o juízo de perigosidade criminal, que implica, de certa forma, predizer a conduta humana futura, se evidencia como altamente inseguro. E sem um diagnóstico seguro sobre as causas da periculosidade ou do comportamento violento, não se poderia proporcionar o tratamento adequado à questão. Além disso, ainda que se conheçam todos os fatores que levam à prática criminosa, isso não significaria o conhecimento, também, dos métodos necessários a tornálos inócuos. Nesse sentido, até o momento em que se tenha conhecimentos suficientemente precisos em matéria de predição do comportamento violento e de prognóstico de perigosidade criminal, a substituição da retribuição pela prevenção especial careceria de racionalidade científica. No que se refere, especificamente, ao tratamento neurológico enquanto medida preventivo-especial, a autora assinala que, a despeito de a neurociência ter logrado apresentar algumas correlações entre déficits (ou alterações) no funcionamento de certas áreas cerebrais - notadamente, o sistema límbico ${ }^{81}$ - e comportamento violento, ainda não aportou conhecimentos suficientes para formular diagnósticos sobre a maior parte da atividade delinquente - a qual, ressalte-se, não é violenta -, de maneira que não se mostra acertado formular propostas gerais a partir de dados que afetam somente uma porção limitada do fenômeno criminal.

81 Conjunto bastante diversificado de regiões do sistema nervoso central as quais têm em comum a participação em funções ligadas às emoções. Apesar da dificuldade em classificá-las, as emoções envolvem sempre três aspectos: (a) um sentimento, que pode ser positivo ou negativo; (b) um comportamento - ou seja, reações motoras características de cada emoção; e (c) ajustes fisiológicos correspondentes (LENT, 2010, pp. 463 e 714). 
PÉREZ MANZANO acrescenta que, além dessas objeções científicas à prevenção especial, há também as críticas de caráter valorativo, mais relevantes do que as primeiras, em sua opinião. Nessa linha, um coerente direito penal de medidas - baseado na perigosidade criminal e orientado à prevenção especial - teria o quantum de suas sanções determinado a partir da periculosidade do sujeito, e não em função das variáveis consideradas atualmente pelos Códigos penais vigentes - tais como a gravidade do fato, o grau de afetação do bem jurídico lesionado ou exposto a perigo e o nível de participação do sujeito na empreitada delituosa, todos critérios consonantes com os princípios fundamentais do Estado de Direito. Assim, um direito penal orientado pela prevenção especial tem como ponto de partida o delinquente, e não o delito, as características pessoais do agente, e não as que configuram o fato, de modo que, partindo-se de que o autor do injusto penal deve ser submetido a tratamento, o tipo e a duração da medida a ser imposta derivará do diagnóstico sobre as causas do comportamento criminoso, do prognóstico acerca da perigosidade criminal e dos graus de necessidade e eficácia terapêutica.

De tudo isso, tem-se, de um lado, que a reação penal preventivo-especial não pode ser determinada a priori, devendo permanecer sempre indeterminada, para que seja ajustada em função do êxito do tratamento; e, de outro, que quanto maior a periculosidade, maior a restrição de liberdade, independentemente da gravidade do fato praticado ${ }^{82}$. Esse quadro, na análise da doutrinadora, não é compatível com um Estado de Direito, que tem por conquista histórica a determinação constitucional de que as penas sejam precisas, encontrem-se determinadas anteriormente à prática do delito e possam ser conhecidas no momento do fato - postulados refletidos nos princípios da legalidade e da segurança jurídica.

Na concepção da professora espanhola, ademais, a fundamentação da pena baseada tão somente na prevenção especial representaria sério risco ao princípio da ofensividade (ou lesividade), segundo o qual ninguém pode ser sancionado por seus pensamentos, por seu modo de ser, mas apenas por ações ou omissões que lesionem ou coloquem em risco algum bem jurídico de relevância penal. Isso porquanto ao se tomar por referência unicamente a periculosidade do sujeito, a necessidade de seu tratamento, abrir-se-ia uma brecha dogmática para a antecipação da tutela penal, sob o argumento de que não seria

\footnotetext{
${ }^{82}$ Por exemplo: o homicídio de um tio idoso para obter sua herança poderia ser sancionado em menor medida que a embriaguez ao volante do caminhoneiro que toma uma xícara de café com conhaque em seu desjejum e uma taça de vinho no almoço, se o prognóstico do sobrinho não evidenciar perigosidade e o do motorista profissional, alcoólatra, apresentar um risco considerável de continuar dirigindo sob o efeito de bebidas alcoólicas (PÉREZ MANZANO, 2011, p. 23).
} 
preciso esperar-se o cometimento do delito para acionar a intervenção estatal, se já fosse identificada antecipadamente a presença, em determinados indivíduos, de fatores determinantes na realização de comportamentos antissociais e criminosos. Em sua compreensão, essa antecipação da intervenção penal para antes da prática do crime restringiria de forma intolerável a liberdade dos cidadãos, vulnerando, portanto, o Estado de Direito. Vulneração essa que poderia ocorrer, ainda, de outra perspectiva: a utilização das classificações "perigosidade" e "sujeitos perigosos" sem amparo técnico-científico, isto é, a partir de um ponto de vista político-ideológico, com finalidades totalitárias, como já verificado em algumas experiências históricas, notadamente em detrimento de grupos sociais minoritários ou desfavorecidos, como pobres, imigrantes e homossexuais.

Ainda no que diz respeito à orientação preventivo-especial do direito penal, PÉREZ MANZANO afirma que se todas as objeções acima expostas já demonstram a necessidade de uma reflexão mais apurada antes da edificação de propostas naquele sentido, em maior medida se revela preciso ter precaução ao tratar-se de formulações que envolvam a intervenção cerebral direta ou indireta (tratamento neurológico). Sustenta a autora, nesse sentido, que o cérebro não é um órgão do corpo humano como os demais, tendo um significado especial como fonte de nossa consciência e de nossa percepção enquanto "eu" ("self"), como constitutivo de nossa subjetividade e como pressuposto fisiológico de nossa identidade, de maneira que qualquer reflexão sobre a possibilidade de tratamentos neurológicos deve partir de que a própria integridade mental é objeto de tutela constitucional e penal - no ordenamento jurídico espanhol, nos arts. 15 e 147 e ss. da Constituição e nos arts. 617 e 621 do Código Penal.

Os déficits de legitimidade da teoria preventivo-especial, tomada isoladamente como fim da pena, e da ideia de tratamento, podem desaparecer, segundo a penalista, no marco de uma teoria mista do direito penal, em cujo âmbito a prevenção especial pode cumprir uma função relevante dando conteúdo a tratamentos reabilitadores. Nesse contexto, ainda que haja temores fundados no meio jurídico-penal acerca da intervenção cerebral, isso não significa seu rechaço absoluto, mormente nas hipóteses em que a autorização daquela seja submetida a específicos controles com relação à existência de conhecimentos científicos suficientemente seguros a respeito.

A tese defendida por PÉREz MANZANo, reforçada nessa época de intensos debates acerca do impacto da neurociência na responsabilidade criminal, se situa no marco das teorias mistas da pena, segundo as quais o objetivo do direito penal é a prevenção dos 
delitos, o qual deve ser cumprido por meio de parâmetros precisos que determinem a pena adequada tanto do ponto de vista da culpabilidade, quanto da perspectiva das necessidades de tratamento preventivo-especial do delinquente. Nesse campo, as pesquisas voltadas ao estudo do cérebro parecem aportar, de acordo com a autora, argumentos a favor dessa concepção: de um lado, por não se vislumbrar a possibilidade de uma prevenção geral sem culpabilidade - já que não se estima possível prescindir dos juízos de mérito e de culpa que se projetam aos indivíduos, nas relações sociais, mediante normas e sanções; de outro, por a neurociência estar contribuindo com conhecimentos fundamentais sobre a incidência de certas disfunções neuronais em alguns comportamentos delitivos - de maneira que se abre a via do tratamento neurológico como instrumento de prevenção especial. A essa solução, defende a doutrinadora, não se chega prescindindo da culpabilidade pelo crime cometido, nem advogando incondicionalmente em favor da intervenção cerebral como forma de controlar a prática delituosa, mas por meio de uma reformulação daquele conceito e de prudência na aprovação dos tratamentos neurológicos.

Desde uma perspectiva puramente científica - excluindo-se, portanto, considerações de caráter valorativo -, parece-nos que a neurociência, em seu atual estágio de desenvolvimento, já tem aportado conhecimentos suficientes a enaltecer uma visão preventiva do direito penal. Com relação à prevenção geral, os robustos resultados de pesquisas envolvendo os processos de formação da vontade no cérebro humano, que demonstram que fatores ambientais - isto é, estímulos externos ao indivíduo - têm influência fundamental em nossos comportamentos, reforçam sobremaneira as teses de que a proibição penal: $(i)$ tem o condão de infundir temor a possíveis delinquentes, sendo apta a afastá-los da prática delitiva (prevenção geral negativa); e (ii) reforça a consciência jurídica de cumprimento da norma, com efeitos de aprendizagem, confiança e pacificação social (prevenção geral positiva). No que se refere à prevenção especial, a neurociência, por meio de suas técnicas, ao possibilitar uma compreensão mais apurada dos mecanismos cerebrais relacionados a determinados tipos de comportamento antissocial - como o agressivo ou violento -, tem logrado, pouco a pouco, mas de forma promissora, associar certas disfunções neuronais a algumas práticas definidas como crime, possibilitando, nesses casos, identificar as causas da atividade delituosa e, assim, atuar sobre o autor do injusto penal para evitar que volte a delinquir no futuro. 
Não obstante esse quadro, se essa contribuição da neurociência às teses preventivas do direito penal implica a emergência de um modelo de responsabilização calcado exclusivamente naquelas finalidades da pena, é outra questão. Em outras palavras, tem-se o seguinte cenário: parece improvável que a doutrina penal ignore que os aportes da neurociência reforçam as noções que fundamentam as finalidades preventivas da pena, de maneira que as teorias absolutas (fundamentadas unicamente no delito praticado; pena enquanto retribuição, apenas) parecem estar em vias de superação; todavia, se como consequência disso prevalecerão no direito penal as teorias relativas (fundamentadas na necessidade de evitar a prática futura de delitos; pena enquanto prevenção, somente) ou as teorias unitárias (ou ecléticas, ou mistas; que buscam conciliar a exigência de retribuição jurídica com as necessidades preventivas), ainda é problema irresolvido pelos penalistas, não só por conta das incertezas envolvendo questões filosóficas como a existência (ou não) de livre-arbítrio, mas também em razão de outros fatores, como, por exemplo, a carga moral (indesejável?) que seria ínsita à ideia de compensação pelo mal causado (retribuição) e a instrumentalização (deletéria?) do indivíduo ligada à noção utilitária da pena enquanto mecanismo de evitação da prática futura de delitos (prevenção).

Questionamentos como esses extrapolam o objeto do presente trabalho, razão pela qual não serão aqui abordados com a profundidade que a matéria exigiria para a formulação de propostas satisfatórias de resolução ${ }^{83}$. Todavia, toda essa problemática é trabalhada, direta ou indiretamente, pelos doutrinadores que, diante da crise do conceito normativo da culpabilidade, delinearam concepções próprias acerca desse elemento do delito, conforme exposto no item "3.5. Panorama atual: alternativas teóricas à culpabilidade normativa" e subitens. Nesse sentido, no capítulo seguinte, buscar-se-á

\footnotetext{
83 Víctor Gabriel RodRíGUEZ (2014, pp. 267 a 307) propôs-se a apresentar respostas a algumas dessas questões em sua tese de livre-docência na Universidade de São Paulo. Nesse sentido, a partir de extensa pesquisa interdisciplinar - nas áreas do direito penal, da filosofia e da neurociência -, o professor de Ribeirão Preto conclui, em sua monografia, que embora se trate de questão intrincada, o futuro do direito penal depende diretamente do posicionamento metafísico sobre a liberdade de vontade, pois ele seria decisivo para a configuração de seus principais institutos, desde as funções da pena e do próprio direito penal, até a estrutura de imputação - especificamente quanto à culpabilidade -, de maneira que a discussão acerca do livre-arbítrio se mostraria premente para os penalistas, especialmente diante dos aportes da neurociência ao problema. Assim, em suma, afirma que não é possível o desenvolvimento da dogmática penal distante de um claro posicionamento na problemática em torno da liberdade de vontade. A esse respeito, buscando formular uma resposta a esse questionamento, RoDRíGUEZ (2014, pp. 279 a 285) apresenta uma proposta de resolução que denomina de "compatibilismo epistemológico" - entre (neuro)determinismo e livre-arbítrio. Mesmo admitindo não ter, com o seu trabalho, o propósito de apresentar um corpo metafísico suficiente a comprovar o livre-arbítrio, o autor compreende como única alternativa coerente, notadamente para o direito penal, aceitar que o ser humano é livre em sua condição metafísica, ou ao menos responsável por seus atos, sem deixar de se reconhecer, por outro lado, que seus comportamentos tenham uma causa física patente e detectável, anterior ao comportamento livre.
} 
analisar a adequação entre as principais propostas alternativas à culpabilidade normativa as quais abordam os problemas acima colocados, desde a perspectiva de seu formulador - e os postulados neurocientíficos, isto é, os conhecimentos dessa disciplina que já podem ser considerados consolidados na comunidade científica. O exame que objetivar-se-á realizar a seguir será de caráter eminentemente científico, voltado investigar se há consonância entre os aportes da neurociência ao estudo do comportamento humano e as mais relevantes propostas teóricas de fundamentação da culpabilidade, de modo que o recorte metodológico selecionado excluirá considerações de cunho valorativo ou que envolvam juízos de conformidade entre a concepção apresentada e princípios penais ou garantias constitucionais.

\subsection{Análise da adequação entre as propostas alternativas à culpabilidade normativa e os postulados neurocientíficos}

A análise que se procederá a seguir buscará verificar se as propostas alternativas à culpabilidade normativa estão em conformidade com os postulados neurocientíficos. Com relação a esses, são aqui compreendidos como as descobertas em neurociência do comportamento - e as conclusões delas extraídas -, tomadas como seguras ou consolidadas no pensamento penal. Assim, expressamente, considerar-se-ão no presente trabalho os conhecimentos neurocientíficos que, por sua aceitação majoritária na área, foram julgados, nos capítulos anteriores, aptos a impactar de forma imediata o direito penal.

Nesse sentido, dois são os postulados que balizarão o exame aqui proposto: (i) a neurociência não foi capaz de resolver o problema da existência de livre-arbítrio, que permanece em aberto, mas, por meio de suas técnicas, tem logrado identificar cada vez mais disfunções cerebrais que impactam diretamente o comportamento humano, acarretando ações ou omissões em que a vontade do indivíduo certamente não é livre ou, ao menos, não é formada dentro de padrões de normalidade cognitiva - ampliando, assim, o espectro da inimputabilidade e conferindo, ainda, maior embasamento teórico às propostas de prevenção especial, como, v. g., o tratamento terapêutico enquanto modalidade de sanção penal; e (ii) a neurociência, desde uma perspectiva não reducionista, tem demonstrado que o ambiente, juntamente com a biologia, exerce papel fundamental na formação da personalidade e como fator de influência direta no comportamento humano de maneira que, mesmo ainda não se sabendo, exatamente, como esses estímulos operam 
no cérebro, tem-se, para o direito penal, a corroboração das teses de prevenção geral negativa e positiva.

Por outro lado, no que se refere às propostas alternativas à culpabilidade, foram selecionadas quatro das mais relevantes formulações, isto é, aquelas com maior importância na dogmática penal desde os critérios da inovação, da profundidade teórica, da influência exercida sobre a doutrina e da representatividade de alguma das duas grandes linhas de pensamento entre os penalistas no que atine à liberdade de vontade - conforme exposto no item "3.6. Considerações finais: indefinição a respeito do conteúdo da culpabilidade (dependência ou independência da ideia de livre-arbítrio)": ( $i$ ) a baseada em sua afirmação, que a encara como uma realidade concreta, sustenta sua existência e formula modelos de culpabilidade nela assentados (Bernd SCHÜNEMANN); (ii) a não baseada em sua afirmação, que elabora estruturas de responsabilização penal indiferentes à demonstrabilidade empírica do fenômeno, seja por considerá-lo uma presunção necessária para o direito penal (Claus ROXIN e Winfried HASSEMER), seja por assentar a punição em outros fundamentos (Günther JAKOBS).

Além dessas considerações preliminares, é relevante pontuar que o presente capítulo parte de uma premissa muito clara: a insatisfatoriedade da concepção normativa da culpabilidade. Insatisfatoriedade essa já bastante enunciada desde quando o conceito entrou em crise na moderna ciência do direito penal (cf., a respeito, o item "3.5. A crise do conceito de culpabilidade normativa"), mas reforçada pelas contribuições da neurociência. De um lado, porque a culpabilidade normativa está fundamentada no livrearbítrio e tem por conteúdo material o "poder agir de outro modo", noções as quais, em razão de sua indemonstrabilidade empírica, caracterizam-se como critérios sobremaneira inseguros para a responsabilização penal, e que, conquanto não sejam infirmadas peremptoriamente pelos conhecimentos neurocientíficos, tornaram-se ainda mais frágeis com as descobertas alcançadas em pesquisas nessa área. De outro lado, porque a culpabilidade enquanto reprovação está intimamente ligada à ideia de pena como retribuição jurídica, vale dizer, como compensação proporcional ao injusto culpável (o qual opera como fundamento e limite da sanção penal), concepção essa que, além de se apoiar em base ética, desconsidera as finalidades preventivas da pena (caras à um direito penal que tem por função precípua a proteção de bens jurídicos fundamentais), cuja eficácia é ratificada pela neurociência. 
Em síntese, não se afirma aqui que o conceito normativo de culpabilidade é incompatível com os conhecimentos atuais em neurociência, pois, para tanto, seria necessário que as pesquisas acerca do funcionamento do cérebro comprovassem que o livre-arbítrio não existe - tratando-se a experiência subjetiva de liberdade de vontade de mera ilusão dos sentidos -, ou que, de alguma outra maneira, seus resultados não se coadunassem com as noções de reprovação e de retribuição. Todavia, ainda não há conclusões definitivas - ou sequer seguras - da neurociência nesse sentido. Dessa maneira, o juízo que ora se apresenta é o de que, considerados os argumentos expostos no parágrafo anterior, a culpabilidade normativa, repousando sobre fundamentos frágeis, se revela insuficiente - e, portanto, inadequada - para ancorar um modelo teórico de consequências práticas tão drásticas como o é o da responsabilização penal. Diante disso é que propostas alternativas a essa concepção devem estar abertas - e ser submetidas - a uma análise de coerência, quer interna, entre os próprios conceitos que abarca, quer externa, sendo cotejada com os princípios da disciplina em que está inserida e com os postulados de outras ciências que, por sua natureza, acabem por necessariamente impactar aquela. É esse último exame que, na sequência, será realizado.

\subsubsection{A proposta de Bernd SCHÜNEMANN}

A formulação do conceito de culpabilidade em Bernd SCHÜNEMANN (2000, pp. 112 e 113; 2009, pp. 470 a 481) tem por traço característico a ancoragem na liberdade de vontade humana. Na concepção do autor, partidário do indeterminismo, o direito penal encontra o livre-arbítrio como uma parte previamente dada da realidade comunicativa, a partir da qual, por meio da linguagem, o indivíduo progressivamente se integra aos valores sociais. Nessa sociedade e cultura, o reconhecimento recíproco da liberdade de vontade derivaria da experiência subjetiva de cada indivíduo e estaria provado pelas estruturas linguísticas: as formas gramaticais ativas ou passivas e a distribuição do caráter dos sujeitos como eu, tu e os terceiros que não participam diretamente da interação seriam a expressão de uma visão de mundo criada por um sujeito que decide livremente.

Além disso, para o professor de Munique, no que se refere às finalidades da pena, a prevenção geral negativa, voltada a motivar o autor ao comportamento conforme o Direito mediante a ameaça de pena, só faria sentido - e seria eficaz - em uma realidade na qual o indivíduo possuísse livre autodeterminação. A razão disso, de acordo com sua visão, é que 
se o sujeito não tem liberdade de decisão, duas são as situações possíveis: ou será forçosamente impedido de praticar o delito mediante a ameaça de sanção penal - de maneira que não haveria fundamento algum para a aplicação da pena; ou os motivos para o cometimento do crime serão de tal modo intensos que a ameaça de pena seria simplesmente inócua.

O fato de SCHÜNEMANN assentar seu conceito de culpabilidade na noção de livrearbítrio já é, por si só, problemático, valendo aqui as mesmas críticas dirigidas à concepção normativa, notadamente de que se trata de fundamento inseguro, uma vez que não demonstrado empiricamente, e cuja existência é objeto de profunda e histórica divergência na filosofia e nas ciências naturais, acentuada com o advento da neurociência. Contudo, a formulação do doutrinador alemão encontra ainda maiores obstáculos teóricos por partir da afirmação de que o livre-arbítrio é algo verdadeiro por conta, em última análise, da experiência subjetiva direta de liberdade de vontade. Isso porquanto tal compreensão ignora a questão - apresentada com ênfase pela neurociência, e discutida também por penalistas - das falsas percepções, isto é, da possibilidade de nossas impressões, eventualmente, basearem-se em ilusões.

Consoante conhecimentos consolidados em neurociência - conforme pormenorizadamente abordado no capítulo "4.2.2. Experiência subjetiva de possibilidade de eleição de condutas: SCHÜNEMANN", e subcapítulos - parece frágil afirmar a existência de liberdade de vontade com base em nossa experiência subjetiva direta, nela fundando a responsabilidade penal. A autoconsciência, ou a sensação de um "self" que controla todos os processos mentais, é, certamente, um requisito para que se cuide de culpabilidade - ao menos do ponto de vista da imputabilidade -, mas se revela insuficiente como meio de fundamentar tal elemento do delito enquanto fenômeno social e jurídico. Se, por um lado, o livre-arbítrio é fenômeno ainda não demonstrado e comprovado empiricamente, por outro, a compreensão neurocientífica de que a impressão de liberdade de vontade parece se tratar, de um modo geral - assim como efetivamente se trata, em casos específicos -, de percepção ilusória, já é razão suficiente para inviabilizar a tese da experiência subjetiva direta de liberdade como fundamento do "poder agir de modo diverso", o qual SCHÜNEMANN reafirma como conteúdo material de seu conceito de culpabilidade.

Ademais, a ideia de prevenção geral intimidatória, contrariamente ao entendimento do penalista, também é compreensível em um sistema determinista - ou compatibilista, ainda que com limitado âmbito de liberdade de vontade. É que nos dois cenários que 
apresenta como possíveis quando o indivíduo age sem livre-arbítrio, as missões tradicionalmente atribuídas ao direito penal são alcançadas. De um lado, se o sujeito foi forçosamente impedido de praticar o delito mediante a ameaça de sanção penal - contexto em que "não haveria fundamento alguma para a aplicação da pena" -, o bem jurídico penalmente relevante protegido pela norma restou eficazmente livre de lesão ou perigo de lesão. De outro, se os motivos para o cometimento do crime são de tal maneira intensos que a ameaça não provoca qualquer efeito, com a imposição de pena como resposta estatal à transgressão à norma penal, de uma perspectiva retribucionista haverá uma compensação pelo mal causado e, portanto, uma reafirmação do Direito que havia sido negada pelo delito; e, desde um ponto de vista preventivo especial, buscar-se-á uma reabilitação do condenado para que, no futuro, prevaleçam em seu processo de formação da vontade os motivos para o cumprimento da lei. Ambas as hipóteses, destarte, estão em consonância com as funções do direito penal - no segundo caso (de eventual cometimento do delito), desde que a prevenção geral negativa não seja considerada isoladamente, isto é, como finalidade única da pena.

Verifica-se, em conclusão, que embora não haja uma incompatibilidade manifesta entre a proposta teórica de SCHÜNEMANN e os postulados neurocientíficos, tampouco se pode afirmar que há conformidade daquela a esses. A crise da concepção normativa da culpabilidade na moderna ciência do direito penal já demonstrou de forma eloquente que modelos de responsabilização penal baseados no livre-arbítrio e preenchidos de sentido pelo "poder agir de outro modo" são sobremaneira insatisfatórios. Insatisfatoriedade essa que se acentua, na formulação do professor de Munique, por se lastrear em um fundamento - a experiência subjetiva de liberdade de vontade - de nenhum respaldo empírico e, mais grave, que ignora o modo como opera o cérebro, notadamente seu funcionamento parte acessível, parte inacessível, à consciência humana, o qual gera, em diversas situações, falsas percepções e ilusões de sentido. Ademais disso, o argumento do penalista alemão de que o conceito de prevenção geral intimidatória só teria sentido em um sistema indeterminista, se revela, a nosso ver, incorreto, na medida em que, como exposto no parágrafo anterior, mesmo se as condutas humanas forem integralmente determinadas aquela finalidade da pena produziria os efeitos desejados, desde uma análise do atingimento das funções do direito penal. Com essas observações em vista, é possível concluir que a concepção indeterminista da culpabilidade em um Direito como realidade 
socialmente criada, proposta por SCHÜNEMANN, se revela pouco adequada aos postulados da neurociência.

\subsubsection{A proposta de Claus RoXIN}

Claus RoXIN (1981,pp. 70 a 72; 1997,pp. 792 a 812) elabora sua proposta teórica acerca da culpabilidade com o intuito de contornar os dois problemas fulcrais da crise da culpabilidade finalista: a indemonstrabilidade do livre-arbítrio e a vinculação da reprovabilidade a valores ético-sociais. Nesse sentido, busca proporcionar uma guinada de enfoque a esse elemento do delito, voltando-o à pergunta de se do ponto de vista penal uma sanção contra um indivíduo concreto é ou não necessária, em vez do questionamento de se outro comportamento do autor era possível nas dadas circunstâncias. Assim, promove o desenvolvimento da culpabilidade normativa até um conceito de responsabilidade, no qual aquela funciona como um dos componentes dessa, em conjunto com elementos de política criminal relacionados à função da pena. Nesse modelo, o injusto - tipicidade e antijuridicidade - relaciona-se à problemática da adequação de determinado comportamento ao direito penal, enquanto que a responsabilidade é atrelada à questão da necessidade de sanção penal em cada caso individual, desde parâmetros político-criminais.

Concretamente, o aperfeiçoamento da responsabilidade roxiniana depende da presença de dois fatores: a culpabilidade do sujeito e a necessidade preventiva da pena, que deve ser deduzida da lei. Nessa formulação, a culpabilidade se perfaz com a realização do injusto, apesar da capacidade de reação normativa e da faculdade de conduzir-se, dela derivada, de maneira que o sujeito atua culpavelmente quando realiza um injusto jurídicopenal, não obstante lhe fosse acessível, na situação concreta, o conteúdo da norma e tivesse capacidade suficiente de autocontrole para adotar uma alternativa de conduta conforme ao Direito. Na construção do professor de Munique, portanto, a culpabilidade segue sendo o pressuposto decisivo - apesar de não mais o único - da responsabilidade penal. Aprimorada em seu conteúdo, tem reforçada, com o estreitamento de sua relação com a punibilidade, a finalidade de impor um limite ao poder punitivo do Estado - especificamente, às necessidades públicas de prevenção.

Na compreensão de Roxin, a culpabilidade deve ser entendida, desde o ponto de vista material, como a atuação injusta apesar da existência de acessibilidade normativa. Em outros termos, isso significa que a culpabilidade se caracteriza quando: (i) um sujeito 
estava disponível, mental e animicamente, no momento do fato para a chamada da norma; (ii) lhe eram psiquicamente acessíveis possibilidades de decisão por uma conduta orientada conforme à norma; e (iii) existia no caso concreto a possibilidade psíquica de controle seja ela livre ou determinada - que há no adulto são na maioria das situações. Para o professor de Munique, diferentemente da "possibilidade de outra conduta pelo autor na situação de cometimento do injusto", os parâmetros apresentados não se consubstanciam em hipótese indemonstrável, mas sim em fenômenos científicos empíricos, mensuráveis pela psicologia e pela psiquiatria, as quais disporiam de conhecimentos para constatar eventuais restrições à capacidade de autocontrole do sujeito, bem como medir sua intensidade.

A existência da acessibilidade normativa, tal qual proposta pelo penalista alemão, pressupõe a ideia de que o sujeito possui capacidade de comportar-se conforme a norma, convertendo-se em culpável ao não adotar nenhuma das alternativas de conduta que em princípio lhe eram psiquicamente alcançáveis. Essa tese, conquanto possa ser interpretada à luz do indeterminismo, não dependeria da existência de liberdade de vontade, sendo também compatível, na compreensão de RoxIN, com o determinismo e com o agnosticismo dos que se declaram desconhecedores da existência ou não do livre-arbítrio. Isso porque, de acordo com essa concepção da culpabilidade, não se afirma que o sujeito pôde efetivamente atuar de outro modo - o que, indiscutivelmente, é impossível de se saber -, mas somente que havendo uma capacidade de autocontrole intacta - e com ela a acessibilidade normativa -, aquele deve ser tratado como livre.

A despeito de Roxin sustentar que um indivíduo com suas faculdades cognitivas regulares (especialmente no que diz respeito à compreensão do conteúdo da norma) e com capacidade de autocontrole intacta deve ser tratado como dotado de liberdade de vontade e de ação - em coerência com sua experiência subjetiva e diante da impossibilidade de uma ordenação razoável da vida humana em sociedade sem a concessão recíproca desse atributo -, sua proposta, de fato, não está ancorada no livre-arbítrio e tampouco depende da comprovação de sua existência - ou de sua demonstração empírica. Por meio de uma análise dos três critérios referidos dois parágrafos acima, que compõem a acessibilidade normativa e, logo, são necessários para a caracterização da culpabilidade roxiniana, nota-se que dizem respeito a condições físicas e mentais as quais se apresentam como pressuposto para que o indivíduo, no momento do fato, receba e compreenda o conteúdo da norma e possa ter seu comportamento influenciado por ela - circunstâncias conciliáveis tanto com 
um universo determinista, quanto com um em que há espaço para a liberdade de vontade humana.

Do exame procedido, verifica-se que há um grau acentuado de compatibilidade entre a concepção de culpabilidade de ROXIN e os postulados neurocientíficos. Em primeiro lugar, porque afastando-se do problema em torno da existência do livre-arbítrio, sua teoria fica menos suscetível de ser desconstruída (ou mitigada) por eventuais descobertas da neurociência que possam comprometer aquela noção - hipótese que não deve ser desconsiderada, já que há uma série de pesquisas, com ampla ressonância na comunidade científica, propondo que o comportamento humano não é originado da vontade livre do indivíduo, mas formado por uma larga gama de fatores que operam deterministicamente. E, em segundo lugar, porquanto, em harmonia com os estudos em neurociência que atestam a (significativa) influência do ambiente nas condutas humanas, o professor de Munique reserva papel especial à finalidade preventiva da pena (enquanto juízo de necessidade da sanção penal desde parâmetros político-criminais) em seu modelo de imputação, compondo, com a culpabilidade, o conceito de responsabilidade.

A única ressalva que se pode fazer à proposta do doutrinador alemão é a de que seu conceito de acessibilidade normativa está permanentemente suscetível de alterações de conteúdo em face do desenvolvimento da neurociência, já que desse certamente derivará a descoberta de novas disfunções cerebrais relacionadas a funções cognitivas e de autocontrole, tornando inculpáveis sujeitos que, anteriormente, seriam considerados culpáveis. Todavia, desse mesmo problema já padecem o conceito normativo de culpabilidade e, aparentemente, todas as propostas alternativas a essa concepção, de maneira que parece se tratar de questão sem resolução a curto e médio prazo. Assim, não obstante essa reserva, conclui-se que a posição integradora de RoxIN, em que a culpabilidade enquanto acessibilidade normativa forma, ao lado da necessidade preventiva da pena (desde parâmetros político-criminais), o conceito de responsabilidade, se mostra bastante adequada aos postulados da neurociência.

\subsubsection{A proposta de Günther JAKOBS}

Assim como RoXIN, Günther JAKOBS (1997, pp. 584 a 586; 2012, pp. 210 a 214; 1992, pp. 1081 a 1083) busca se afastar da problemática do livre-arbítrio. Formula, então, um modelo de responsabilização penal não calcado na ideia de reprovabilidade, mas 
fundado na manutenção da ordem social - logo, não fundamentado na liberdade de vontade do agente. Na compreensão do doutrinador, sendo a culpabilidade a atribuição de responsabilidade em razão da lesão da vigência da norma, não faz sentido introduzir o questionamento acerca da existência de livre-arbítrio, pois o único pressuposto desse elemento do delito é que o sujeito possa ser, desde parâmetros cognitivos, motivado pela norma, e nada além disso.

Conforme essa orientação, em que a culpabilidade não é o mesmo que reprovabilidade, mas que consiste em um déficit de fidelidade ao ordenamento jurídico cuja consequência é a pena, concebida com a finalidade de reforçar a validade da norma, assegurando a manutenção da ordem social -, não importa se a vontade do sujeito que praticou o injusto era livre, mas apenas se ela foi formada em condições de normalidade cognitiva. Somente nas hipóteses de erro caracterizado em razão de defeitos cognitivos, a culpabilidade pode ser excluída ou diminuída. JAKOBS define o que são os defeitos cognitivos diferenciando-os dos defeitos volitivos. Para chegar a essa especificação, parte da ideia de que as condições psíquicas que devem estar cumpridas para que uma norma seja respeitada, são, de um lado, a motivação para obedecê-la e, de outro, a capacidade mental de reconhecê-la e acatá-la, constituindo-se o comportamento, pois, de uma prestação volitiva (querer) e de uma prestação cognitiva (conhecer e compreender), respectivamente. Enquanto a ocorrência de um defeito volitivo, via de regra, agrava a responsabilidade, essa é exonerada - ou minorada - na hipótese de um defeito cognitivo.

Assim, de acordo com o autor, quanto menor for a vontade do sujeito de respeitar a norma - ou, do ponto de vista inverso, quanto maior e mais obstinada for a infidelidade à norma da atitude do sujeito -, mais grave será sua culpabilidade, a qual será menor, contrariamente, se tal déficit de fidelidade ao direito aparecer com um passo em falso eventual, atípico. Com relação aos aspectos cognitivos do agente, quanto maior for a distância que o separar dos conhecimentos necessários - definidos normativamente -, menor será sua culpabilidade, ao passo que essa terá intensidade superior na medida do quanto maior for a possibilidade de superar o desconhecimento. Defende o professor de Bonn, ainda, ser certo que a culpabilidade está relacionada com a liberdade, mas não com a liberdade de vontade, com o livre-arbítrio, e sim, tão somente, com o que denomina de liberdade de autoadministração própria, ligada à possibilidade de o sujeito agir sem a presença de obstáculos juridicamente relevantes para seus atos de organização. 
Ao substituir no conteúdo material da culpabilidade o "poder agir de outro modo" pela "motivabilidade normal do agente", JAKOBS se afasta da problemática da ausência de comprovação científica do livre-arbítrio, uma das responsáveis pela crise da concepção normativa da culpabilidade. Contudo, sua proposta não se apresenta mais satisfatória do que aquele conceito consolidado na doutrina penal tradicional, uma vez que padece de um defeito praticamente idêntico, vale dizer: a capacidade normal, em um indivíduo, de ser motivado pela norma se trata de atributo de difícil demonstração empírica. Como abordado detalhadamente no item "4.3.2. Comportamento criminoso, normalidade cognitiva e motivação pela norma: JAKOBS", e subitens, no estágio atual de evolução científica e tecnológica, ainda não é possível estabelecer um paradigma definitivo de cérebro normal (ou saudável) para fins de atribuição de responsabilidade penal, uma vez que o conhecimento que há atualmente acerca do funcionamento sistema nervoso central não permite que se mapeie, com precisão, o processo de formação da vontade em um organismo saudável e se identifique, com segurança, as disfunções que repercutem na motivação da ação pela norma. Isso significa que, ao menos em grande parte dos autores de injustos penais, não é possível comprovar empiricamente se foram (ou não) normalmente motivados pela norma.

Em face disso, é possível concluir que a motivação normal do agente pela norma somente será um critério seguro de determinação da culpabilidade se deixar de ser uma assunção normativa - dependente do conhecimento científico da época a respeito do funcionamento do cérebro humano, e de interpretações àquele subjacentes voltadas a formulação de padrões físicos e mentais - e passar a apresentar uma abordagem de carga ontológica, o que só deve ocorrer no futuro, quando tivermos uma compreensão mais completa de como opera a formação da vontade no ser humano. No que diz respeito à culpabilidade, portanto, considerando as questões acima colocadas, a formulação teórica de JAKOBS não está integralmente em conformidade com os conhecimentos atualmente disponíveis em neurociência. Por outro lado, sua orientação funcionalista segundo a qual o sistema jurídico-penal deve se orientar pela missão do direito penal (de proteção da validade das normas), cuja expressão mais patente é a finalidade preventivo-geral da pena, encontra-se em consonância com os postulados neurocientíficos que afirmam a influência dos fatores ambientais (valores culturais, morais, jurídicos) no comportamento humano. Considerando-se ambas as perspectivas acima retratadas, conclui-se que a culpabilidade 
como um déficit de fidelidade ao ordenamento jurídico, formulada por JAKOBS, se mostra relativamente adequada aos postulados da neurociência.

\subsubsection{A proposta de Winfried HASSEMER}

Winfried HASSEMER (1999, pp. 51 a 62), partindo da constatação de que o princípio da culpabilidade encontra-se ameaçado no direito penal atual - tanto na teoria (em razão das inconsistências da concepção normativa), quanto na práxis (pelos interesses de uma política criminal eficaz) -, constrói um modelo que renuncia à ideia de reprovação, a qual considera insustentável do ponto de vista teórico (por conta da vinculação à noção de livrearbítrio) e prejudicial de uma perspectiva prática (devido à carga ética envolvida), mas que conserva o que considera serem as missões irrenunciáveis da culpabilidade: possibilidade de imputação subjetiva, exclusão da responsabilidade pelo azar, diferenciação e valoração da participação interna no acontecimento externo e garantia da proporcionalidade das consequências jurídico-penais.

Para o professor de Frankfurt, ainda que não se possa conceber o direito penal e a vida cotidiana sem a ideia de liberdade de vontade, nem se possa compreender as relações humanas em geral desde um panorama determinista, revela-se um acerto a desvinculação, pela dogmática da culpabilidade, da polêmica acerca do livre-arbítrio. Isso porque, em sua compreensão, a ideia da liberdade como condição, ainda que transcendental, da possibilidade de comunicação humana - como defendido, por exemplo, por SCHÜNEMANN não é apta a servir de base a uma reprovação penal frente ao delinquente. De acordo com o autor, as circunstâncias em que uma condenação pode fundamentar-se devem estar reunidas, como um todo, dentro do processo penal, submetido ao método da observação. Nesse contexto, a questão do livre-arbítrio restaria subtraída a priori, antes mesmo do início da observação, voltando-se o processo penal, por meio de seu instrumental, para a verificação de eventuais limitações materiais da liberdade de vontade, vale dizer, de indicadores de déficit de liberdade no caso concreto, a partir dos conhecimentos científicos, inclusive - disponíveis.

Nesse sentido, HASSEMER (2011, pp. 1 a 15) sustenta que as causas de exclusão da culpabilidade são a porta pela qual os conhecimentos consolidados das ciências empíricas do ser humano alcançam a aferição jurídico-penal da culpabilidade. Em outros termos, as categorias de exclusão da culpabilidade seriam as constelações nas quais o direito penal e 
as ciências empíricas - dentre elas, a neurociência - entram em contato, penetrando-se mutuamente. Seu estado atual, afirma o autor, é o resultado de evoluções de longo prazo nas ciências empíricas, mas também da decisão jurídico-penal sobre a relevância de tal aporte do desenvolvimento científico no modelo de atribuição de responsabilidade penal e, especificamente, na culpabilidade. Assim, segundo o professor de Frankfurt, mostra-se acertada a previsão, na lei penal, de situações nas quais a exculpação está justificada - vale dizer, de graves anomalias, de erro, de inexigibilidade de comportamento conforme ao Direito. Isso porque o caráter histórico dessas hipóteses, enriquecidas de significado pelas discussões realizadas na teoria e na práxis, demonstraria que tais condições não são indícios negativos de liberdade de ação e de reprovação, mas sim limites de criminalização próprios de um direito penal humano. Assim, atento o juiz penal a esse programa, estaria assegurado que a ninguém viesse a ser imposta uma consequência jurídico-penal por haver cometido um fato pelo qual não é responsável.

A respeito das sanções penais, HASSEMER (2004, pp. 45 a 82) entende que seus limites devem ser deduzidos dos critérios de proporcionalidade e sua intensidade deve considerar parâmetros como a gravidade do fato e a sensibilidade e a receptividade do condenado à pena. No que tange às finalidades da pena, seu posicionamento com relação à prevenção geral é dúplice. Com a ressalva de que os fins preventivo-gerais da sanção penal têm sido utilizados de maneira indiscriminada e descriteriosa na práxis forense, o professor de Frankfurt sustenta que a aplicação da pena orientada pela finalidade de prevenção geral positiva - isto é, voltada à estabilização da consciência social de respeito à norma e de confiança no ordenamento jurídico - é legítima na medida em que seja possível uma valoração precisa de sua eficácia, baseada em conhecimentos empíricos seguros. Por outro lado, no que se refere à prevenção geral negativa, direcionada à intimidação, o doutrinador alemão julga padecer de insolúveis problemas empíricos e metodológicos, o que, em sua análise, a tornaria ilegítima para fundamentar a imposição (e o agravamento) de uma sanção penal: haveria, quanto a essa finalidade da pena, uma carga "simbólica" da intervenção penal (por meio de penas severas, em uma situação normativa ameaçante, o sistema de direito penal simbolizaria que pode responder à situação de transgressão, que nela está presente e que a domina), a qual, ao repercutir em um caso concreto, individual, por meio da exarcebação da punição, defrontar-se-ia com uma série de objeções de índole constitucional, além daquelas de natureza ética. 
À parte as reservas apresentadas, o pensamento de HASSEMER coaduna-se com os conhecimentos disponíveis em neurociência, na medida em que reconhece que o objeto da prevenção geral positiva - vale dizer, a influência que se exerce no comportamento dos membros de uma sociedade ao se reforçar a confiança na norma por meio da punição àquele que a transgrediu - é passível de ter sua eficácia comprovada pelas ciências empíricas. A despeito da ausência de uma literatura específica com dados definitivos nesse sentido, a neurociência tem demonstrado que o ambiente - com destaque para a cultura, os valores morais e as regras jurídicas vigentes -, juntamente com a biologia, exerce papel fundamental na formação da conduta humana. Diante dessa verificação, e considerando ainda que o autor estrutura um modelo de responsabilização penal não fundamentado no livre-arbítrio, é possível concluir que a culpabilidade sem reprovação de HASSEMER é bastante adequada aos postulados da neurociência.

\subsection{Considerações finais: conhecimentos consolidados da neurociência no presente e perspectivas teóricas para o futuro da culpabilidade}

Do exposto no presente capítulo, aliado a toda a discussão desenvolvida no presente trabalho, pode-se concluir que, à parte todas as possíveis (e promissoras) contribuições que as pesquisas neurocientíficas podem oferecer ao sistema de justiça criminal a médio e longo prazo, dois são os aportes da neurociência que, a nosso ver, já podem impactar, de forma imediata, o direito penal: $(i)$ os relacionados à identificação de disfunções cerebrais que repercutem diretamente no comportamento humano, acarretando ações ou omissões em que a vontade do indivíduo certamente não é livre ou, ao menos, não é formada dentro de padrões de normalidade cognitiva - ampliando, assim, o espectro da inimputabilidade e conferindo, ainda, maior embasamento teórico às propostas de prevenção especial, como, por exemplo, o tratamento terapêutico enquanto modalidade de sanção penal; e (ii) aqueles relacionados à demonstração da influência do ambiente - especialmente, fatores culturais, morais e jurídicos - na formação da personalidade e na realização das condutas humanas corroborando as teses de prevenção geral negativa e positiva.

Levando em consideração a verificação acima, e tomando por referência as análises de Eduardo Demétrio Crespo, Diego-Manuel Luzón PeÑA, Winfried Hassemer e Günther JAKOBS (cf., a respeito, o item “5.3.1. O fim da culpabilidade?”), é possível assentar que a neurociência não representa um risco à permanência da culpabilidade na 
estrutura do delito, notadamente porque a parcela da doutrina penal que de alguma forma tem reservas quanto ao impacto dessa disciplina no direito penal não a rejeita absolutamente, mas tão somente critica o neurodeterminismo, isto é, a visão determinista retomada a partir das pesquisas de investigação do cérebro. Assim, a despeito da (não tão recente) crise da concepção normativa da culpabilidade e do amplo e irresolvido debate em torno de sua função no âmbito da imputação jurídico-penal, a doutrina recusa, quase que unanimemente, a supressão daquele elemento do modelo de responsabilização penal. De maneira também quase consensual, os penalistas vêm admitindo o influxo das biociências em determinados campos da teoria do crime, como, por exemplo, nas causas de exclusão da culpabilidade, especialmente na aferição da imputabilidade do autor de um injusto penal.

No atual estágio de desenvolvimento da neurociência, portanto, pode-se assentar com tranquilidade que o advento do estudo do cérebro não representa o fim da culpabilidade. O que permanece em aberto, carente de definição, todavia, é qual natureza de seu conteúdo material prevalecerá na doutrina penal: a retribucionista - baseada na possibilidade de se agir de modo diverso; ou a preventiva - ancorada na acessibilidade à norma ou na capacidade de motivação por essa. Nessa linha, desde uma perspectiva puramente científica - excluindo-se, portanto, considerações de caráter valorativo -, parecenos que a neurociência do passado e do presente já tem aportado conhecimentos suficientes a enaltecer uma visão preventiva do direito penal.

No que atine à prevenção geral, os robustos resultados de pesquisas envolvendo os processos de formação da vontade no cérebro humano, que demonstram que fatores ambientais - isto é, estímulos externos ao indivíduo - têm influência fundamental em nossos comportamentos, reforçam sobremaneira as teses de que a proibição penal tem o condão de infundir temor a possíveis delinquentes - sendo apta a afastá-los da prática delitiva (prevenção geral negativa) - e reforça a consciência jurídica de cumprimento da norma - com efeitos de aprendizagem, confiança e pacificação social (prevenção geral positiva). Com relação à prevenção especial, a neurociência, por meio de suas técnicas, ao possibilitar uma compreensão mais apurada dos mecanismos cerebrais relacionados à determinados tipos de comportamento antissocial - como o agressivo ou violento -, tem logrado, paulatinamente, e de forma promissora, associar certas disfunções neuronais a algumas práticas definidas como crime, possibilitando, nesses casos, identificar as causas 
da atividade delituosa e, assim, atuar sobre o autor do injusto penal para evitar que volte a delinquir no futuro.

Não obstante esse quadro, se essa contribuição da neurociência às teses preventivas do direito penal implica a emergência de um modelo de responsabilização calcado exclusivamente naquelas finalidades da pena, trata-se de outra questão. Em outras palavras, tem-se o seguinte cenário: parece improvável que a doutrina penal ignore que os aportes da neurociência têm reforçado as noções que fundamentam as finalidades preventivas da pena, de maneira que as teorias absolutas (fundamentadas unicamente no delito praticado; pena enquanto retribuição, apenas) parecem estar em vias de superação; todavia, se como consequência disso prevalecerão no direito penal as teorias relativas (fundamentadas na necessidade de evitar a prática futura de delitos; pena enquanto prevenção, somente) ou as teorias unitárias (ou ecléticas, ou mistas; que buscam conciliar a exigência de retribuição jurídica com as necessidades preventivas), ainda é problema irresolvido pelos penalistas, não só por conta das incertezas envolvendo questões filosóficas como a existência (ou não) de livre-arbítrio, mas também em razão de outros fatores, como, por exemplo, a carga moral (indesejável?) que seria ínsita à ideia de compensação pelo mal causado (retribuição) e a instrumentalização (deletéria?) do indivíduo ligada à noção utilitária da pena enquanto mecanismo de evitação da prática futura de delitos (prevenção).

Questionamentos como esses extrapolam o objeto da presente pesquisa, razão pela qual não foram aqui abordados com a profundidade que a matéria exigiria para a formulação de propostas satisfatórias de resolução. Com efeito, o exame que ora se realizou voltou-se a investigar se há consonância entre os aportes da neurociência ao estudo do comportamento humano e as mais relevantes propostas teóricas de fundamentação da culpabilidade, de modo que o recorte metodológico selecionado excluiu considerações de cunho valorativo ou que envolvam juízos de conformidade entre a concepção apresentada e princípios penais ou garantias constitucionais.

Dessa análise, verificou-se, preliminarmente, a insatisfatoriedade da concepção normativa da culpabilidade - insatisfatoriedade já bastante enunciada desde quando o conceito entrou em crise na moderna ciência do direito penal, mas reforçada pelas contribuições da neurociência. De um lado, porque a culpabilidade normativa está fundamentada no livre-arbítrio e tem por conteúdo material o "poder agir de outro modo", noções as quais, em razão de sua indemonstrabilidade empírica, caracterizam-se como critérios sobremaneira inseguros para a responsabilização penal, e que, conquanto não 
sejam infirmadas peremptoriamente pelos conhecimentos neurocientíficos, tornaram-se ainda mais frágeis com as descobertas alcançadas em pesquisas nessa área. De outro lado, porque a culpabilidade enquanto reprovação está intimamente ligada à ideia de pena como retribuição jurídica, vale dizer, como compensação proporcional ao injusto culpável (o qual opera como fundamento e limite da sanção penal), concepção essa que, além de se apoiar em base ética, desconsidera as finalidades preventivas da pena (caras à um direito penal que tem por função precípua a proteção de bens jurídicos fundamentais), cuja eficácia é ratificada pela neurociência.

Importante ressaltar que não se afirma aqui que o conceito normativo de culpabilidade é incompatível com os conhecimentos atuais em neurociência, pois, para tanto, seria necessário que as pesquisas acerca do funcionamento do cérebro comprovassem que o livre-arbítrio não existe - tratando-se a experiência subjetiva de liberdade de vontade de mera ilusão dos sentidos -, ou que, de alguma outra maneira, seus resultados não se coadunassem com as noções de reprovação e de retribuição. Todavia, ainda não há conclusões definitivas - ou sequer seguras - da neurociência nesse sentido. Dessa maneira, o juízo que ora se apresenta é o de que, considerados os argumentos retomados e sintetizados no parágrafo anterior, a culpabilidade normativa, repousando sobre fundamentos frágeis, se revela insuficiente - e, portanto, inadequada - para ancorar um modelo teórico de consequências práticas tão drásticas como o é o da responsabilização penal.

Considerando-se essa realidade é que se revela a necessidade de buscar alternativas teóricas à culpabilidade normativa, em estruturas não fundamentadas na liberdade de vontade. Da análise da compatibilidade entre as principais formulações alternativas à culpabilidade finalista existentes atualmente (candidatas a substituir aquela concepção na teoria do delito, e a influenciar as legislações penais) e os postulados neurocientíficos, algumas conclusões foram alcançadas. A primeira delas, de que as propostas teóricas mais adequadas aos conhecimentos em neurociência são as de Claus RoxIN e Winfried HASSEMER, na medida em que ambos não fundamentam seu conceito de culpabilidade no livre-arbítrio (ou no "poder agir de outro modo"), bem ainda reconhecem a eficácia das finalidades preventivo-gerais da pena - sendo que o professor de Munique vai além, conferindo-lhes posição de destaque em seu modelo de responsabilização penal. Günther JAKOBS, por sua vez, a despeito de reconhecer a importância da prevenção geral para o direito penal, e apesar de também buscar desvincular a estrutura de imputação da ideia de 
liberdade de vontade, assenta a culpabilidade na "motivabilidade normal do agente pela norma", noção que apresenta um déficit de demonstrabilidade empírica próximo àquele atributo, de maneira que o conceito que delineia acaba por se revelar apenas relativamente adequado aos postulados da neurociência. Dos autores estudados, aquele cuja proposta tem a menor adequação aos conhecimentos neurocientíficos é Bernd SCHÜNEMANN, uma vez que, além de baseada no livre-arbítrio e preenchida de sentido pelo "poder agir de outro modo", é justificada a partir da experiência subjetiva de liberdade de vontade, fundamento sem respaldo empírico e alheio ao modo como opera o cérebro, notadamente seu funcionamento parte acessível, parte inacessível, à consciência humana, o qual gera, em diversas situações, falsas percepções e ilusões de sentido.

Realizado o escrutínio proposto - e alcançadas as conclusões expostas -, pode-se apontar como perspectiva teórica para o futuro da culpabilidade a emergência (e prevalência) de modelos de responsabilização próximos aos formulados por RoxIN e HASSEMER, ao menos no que diz respeito às seguintes características: não fundamentação da punição no "poder agir de outro modo" ou, de maneira mediata, no livre-arbítrio; e presença de critérios de imposição e dosimetria da pena que levem em consideração suas finalidades preventivas. 


\section{EPÍlOGO: O ESTUDO DO CÉREBRO E O FUTURO DO DIREITO PENAL}

Além das questões que envolvem o processo de tomada de decisão no cérebro humano - e que, como visto, repercutem diretamente na responsabilização criminal -, o desenvolvimento da neurociência ainda reserva outros desafios ao direito penal em um futuro não muito distante, relacionados, principalmente, aos seguintes temas: "enhancement" cerebral; interface cérebro-máquina; e inteligência artificial. Com relação ao primeiro deles, trata-se de questão já abordada neste trabalho, no item "5.2. A hipótese da transgressão penal enquanto indício de anormalidade cerebral (...)", em virtude de sua aventada aplicação como pena, voltada à prevenção especial - isto é, à recuperação do condenado -, de maneira que um panorama geral do assunto, com a abordagem de seus principais pontos, já está ali elaborado. No que diz respeito aos dois outros temas, contudo, convém aqui traçar linhas breves, de maneira a delinear algumas perspectivas de influência das pesquisas neurocientíficas no direito penal do porvir.

A interface cérebro-máquina - ou interface cérebro-computador ("brain-machine interface"; ou "brain-computer interface") - consiste em um caminho comunicativo direto entre o cérebro e um dispositivo artificial (externo ou interno). Trata-se, na explicação dos neurocientistas Parag G. PATIL e Dennis A. TURner (2008, pp. 137 a 146) de um campo de estudo voltado a compreender a comunicação entre as diversas estruturas neurais para, em caso de falha em seu funcionamento - devido a doenças ou lesões, verbi gratia -, a transmissão biológica de sinais cerebrais possa ser substituída por outra de natureza tecnológica, vale dizer, por um dispositivo neuroprotético. Um exemplo de possível aplicação desse conhecimento é o de indivíduos com defeito na comunicação entre o cérebro e as extremidades corporais em virtude de lesões medulares. Em casos como esse, os pacientes podem ser equipados com dispositivos neuroprotéticos que promovem a interação entre cérebro e computador, possibilitado a leitura e a interpretação dos sinais emitidos diretamente do córtex motor, de modo a controlar a atividade de uma prótese exterior e retornar apropriadamente os estímulos externos ao córtex sensorial, permitindo o controle de circuito fechado de um braço robótico, devolvendo àquelas pessoas movimentos que haviam perdido.

De acordo com PATIL e TURNER, a evolução no campo da interface cérebromáquina tem se apresentado como o futuro da neuroprotética, sendo que muitas das 
tecnologias que serão necessárias à tradução clínica dos sinais neurais para computadores já estão em desenvolvimento, incluindo uma nova geração de eletrodos de registro. Além disso, são cada vez maiores as informações disponíveis acerca da decodificação e da interpretação de sinais subjacentes à vontade e ao planejamento, do "feedback" somatosensorial direto ao sistema nervoso (voltado a refinar ações), e do estímulo à plasticidade dos circuitos neurais por meio de treinamentos específicos. Não obstante esse quadro promissor - que inclui pesquisas pré-clínicas em primatas não humanos, as quais demonstram alta eficácia de registros do córtex motor em tarefas que exijam movimento (cf. NiCOlELis, 2001, pp. 403 a 407; CARMENA et al., 2003, pp. 193 a 208) -, os autores ressaltam que ainda há muitos desafios relacionados à tradução de sinais. Nesse sentido, o primeiro deles é o desenvolvimento de eletrodos biocompatíveis capazes de registrar a atividade cerebral de modo estável e a longo prazo, bem como de amplificadores implantáveis e de processadores de sinal suficientemente resistentes ao barulho, além de dispositivos aptos a transmitir fielmente os estímulos recebidos do ambiente externo.

De todo modo, observam os pesquisadores, devido a sua aparente viabilidade comercial, a tecnologia neuroprotética de interface cérebro-máquina tende a progredir em ritmo acelerado, com o objetivo maior de desenvolver um dispositivo que permita a tradução perfeita de pensamentos em ações de uma maneira completamente natural e transparente para seu usuário. Assim, apesar dos consideráveis desafios pela frente, como a compreensão dos códigos neurais por trás da vontade e da ação, a produção de eletrodos biocompatíveis com capacidade para entregar sinais duradouros e silenciosos partindo de relevantes regiões do cérebro, e o desenvolvimento de técnicas de implantação de microdispositivos em seres humanos de forma confiável e segura, as perspectivas são positivas, uma vez que, nos últimos quarenta anos, a interface cérebro-máquina passou da esfera da ficção científica para a realidade, já apresentado uma tecnologia que, conquanto ainda rudimentar, revela-se promissora no cenário clínico.

Nesse contexto de consolidação dos conhecimentos acerca da interface cérebromáquina, surgem algumas potenciais ameaças a bens jurídicos de índole penal, atinentes, principalmente, às questões de segurança da informação e privacidade e de integridade tanto física e mental de seres humanos, quanto a de sistemas informáticos. Nessa linha, Stephen S. Wu e Marc Goodman (2013, pp. 68 a 71), considerando já haver registros criminais nos Estados Unidos da América de invasão de sistemas informatizados ("hacking") de natureza médica, como marcapassos, demonstram preocupação quanto a 
esse tipo de conduta ser realizada também em detrimento de dispositivos implantados no corpo humano, notadamente os que operam por meio de transmissão de informação sem fio ("wireless"), tais como os controladores de membros protéticos e os estimuladores cerebrais profundos.

$\mathrm{Na}$ visão dos penalistas, a ameaça aos dispositivos neuroprotéticos se revela muito mais grave do que aos computadores ou à internet, na medida em que, no caso desses, apenas bens materiais e dados são afetados - ao menos em um primeiro momento. Com relação àqueles, por outro lado, sua invasão e manipulação indevida representa sério risco de lesão à integridade física e mental, e até mesmo à vida, do potencial ofendido. Assim, tal conduta pode não somente causar danos irreversíveis a funções cognitivas, como o aprendizado e a memória, mas também levar à morte do paciente, a depender da área cerebral que vier a sofrer intervenção.

Além dos perigos citados, Wu e GOODMAN mencionam outro, relacionado à proteção da privacidade. Argumentam os autores que as organizações empresariais que venderem e fornecerem serviços de manutenção de dispositivos neuroprotéticos podem vir a ter acesso irrestrito à informação privada armazenada no cérebro humano, condição que demanda regulamentação absolutamente criteriosa de tais atividades, de modo a estabelecer um controle técnico minucioso acerca da produção de tais equipamentos, a fim de assegurar um resguardo eficaz dos dados ali constantes. A proteção da intimidade dos dados conservados em bases neurofisiológicas - como as que compõem, principalmente, a memória - é imprescindível porque, assim como, em certa medida, a informação constante do material genético, permitem que se leia o "livro da vida" de um indivíduo, possibilitando a utilização de tais conhecimentos para fins eticamente condenáveis discriminatórios, particularmente -, especialmente em searas nas quais estão presentes interesses econômicos mais diretos, como relações laborais e contratos securitários (RoDRÍGUEZ, 2008, pp. 177 a 222).

Diante desse quadro, parece, pelo menos à primeira vista, que o direito penal já conta com alguns instrumentos aptos a proteger os bens jurídicos potencialmente ameaçados em face do desenvolvimento da tecnologia de interface cérebro-máquina - v. $g$., tipificação penal das condutas de ofender a integridade corporal ou a saúde de outrem (Código Penal, art. 129) e de invadir dispositivo informático alheio (CP, art. 154-A). Todavia, por tal advento trazer à realidade social riscos à vida, à integridade física e mental e à privacidade dos seres humanos em níveis completamente novos, um debate amplo e 
profundo sobre as questões ora abordadas, tanto no plano político, quanto no plano científico se revela necessário, com vistas a, entre outras coisas, oferecer subsídios firmes e coerentes acerca do papel do sistema jurídico-penal nesse processo. Até lá, antes de uma discussão séria sobre o assunto, qualquer intervenção penal que leve a uma maior criminalização de condutas, em detrimento de princípios penais como os da subsidiariedade e da fragmentariedade, se revelará açodada.

Desde outro panorama, a inteligência artificial é, basicamente, a capacidade de sistemas computacionais pensarem (no sentido de elaborar raciocínios) e agirem racionalmente. Trata-se de um campo de estudo amplo, mas voltado, de um modo geral, à compreensão e à construção de agentes inteligentes, isto é, de mecanismos informáticos como os robôs - que percebem os estímulos provenientes do ambiente a sua volta e fazem escolhas (e realizam ações) que maximizam suas chances de sucesso (RUSSEL; NoRviG, 1995, pp. VIII e 4 a 8). A despeito de sua feição futurista, a inteligência artificial já faz parte do mundo atual, estando presente desde dentro das nossas casas (com mecanismos de busca via internet por meio de microcomputadores), até os campos de batalha (em veículos aéreos não tripulados, por exemplo), de maneira que constitui uma realidade cotidiana na vida da maioria das pessoas.

Todavia, apesar de a inteligência artificial se tratar de algo de certa forma trivial na sociedade hodierna, suas perspectivas de desenvolvimento - como, por exemplo, a fabricação de robôs que possam funcionar como cuidadores de idosos, tecnologia em projeto no Japão - têm preocupado alguns pesquisadores da área. Nesse sentido, segundo o bioeticista Wendell WALLACH (2011, pp. 185 a 207), com a crescente complexidade dos sistemas robóticos, projetistas e engenheiros não poderão prever sempre como tais máquinas agirão quando confrontadas com novas situações e estímulos não antevistos. Em sua visão, a operação completa de cada componente físico de um sistema somente será compreendida pelos responsáveis por seu desenho e fabricação, e até mesmo esses possivelmente terão pouco ou nenhum entendimento de como aquele componente interagirá com os demais em um dispositivo totalmente novo, o que certamente prejudicará o conhecimento dos potenciais riscos que tal equipamento pode trazer. Além disso, acrescenta o autor, os perigos inerentes ao desenvolvimento da inteligência artificial não derivam apenas de eventuais erros de projeto ou de fabricação dos agentes inteligentes, 
mas de sua própria natureza de entes capazes de acumular conhecimentos e aperfeiçoar seu funcionamento de acordo com a experiência.

Enquanto sistemas capazes de compreender o ambiente ao seu redor e de realizar as escolhas mais adequadas de acordo com os estímulos percebidos, os agentes inteligentes são capazes, em teoria (idealmente), de acumular e integrar conhecimentos, adquirindo experiência a partir de situações passadas e com elas aprendendo. Tal aptidão torna possível, em tese, que robôs, por exemplo, passem a realizar ações pautadas em fatores de índole pragmática ou utilitária, em uma análise isenta de considerações éticas ou morais. A questão do desenvolvimento de máquinas morais ("moral machines"), sensíveis a ponderações de caráter ético ou moral em suas escolhas e ações, que limitem a possibilidade de realização de atividades deletérias à sociedade, desafia os pesquisadores da área. Entretanto, é difícil, com os conhecimentos disponíveis atualmente, conceber dispositivos inteligentes que adequadamente se conformem aos valores humanos - até porque pouco se sabe, na neurociência, a respeito de suas bases físicas (cerebrais). Além disso, tampouco há consenso acerca de quais princípios integrariam uma moral ideal, de maneira que a constituição do que seria um modo de agir correto pode variar nos mais diversos grupos sociais, a tornar mais difícil a tarefa de transpor tais fatores imateriais de influência do comportamento humano aos agentes inteligentes artificiais.

Diante desse contexto, nota-se que a responsabilidade legal por danos (ou perigos de dano) causados por agentes inteligentes em razão de erros de projeto ou de fabricação pode ser tranquilamente atribuída, a partir dos instrumentos dogmáticos atualmente disponíveis, às pessoas (físicas e jurídicas) encarregadas, incumbidas ou de algum modo vinculadas juridicamente a tais tarefas, desde que preenchidos os requisitos estipulados para tanto. Contudo, no que atine às máquinas inteligentes desenvolvidas conforme os protocolos estabelecidos, mas que, em razão de sua elevada tecnologia são capazes de melhorar progressivamente sua capacidade de aprendizado, acumulando novos conhecimentos e desenvolvendo padrões de ação em níveis de tal maneira complexos que seriam inviáveis de se antever, as possibilidades de intervenção jurídica se mostram mais incertas.

Quem responsabilizar, se for o caso de se responsabilizar, civil e penalmente na hipótese - atualmente, ainda com aparência de ficção científica - de um robô construído para cuidar e proteger uma criança pequena (em atividade autorizada pelo poder público, suponhamos) que, percebendo equivocadamente estímulos do ambiente, interpreta uma 
situação de brincadeira como de agressão e, por isso, provoca lesões corporais em terceira pessoa? A evolução da inteligência artificial, orientada a aproximar cada vez mais as atividades de agentes inteligentes àquelas que os seres humanos podem realizar, traz desafios em tal medida vastos e inusitados que se inicia uma discussão, no âmbito da filosofia e do Direito, em torno da possível atribuição de personalidade às máquinas inteligentes - inclusive com o fim de lhes garantir certas proteções constitucionais, de maneira análoga aos direitos individuais assegurados às pessoas (CHOPRA; WHITE, 2014, pp. 701 a 709).

Observa-se, portanto, que o tratamento da questão da inteligência artificial se mostra sobremaneira desafiador, a exigir de filósofos e juristas - penalistas, inclusive - um acompanhamento próximo do desenvolvimento de suas tecnologias, para que se possa delinear as consequências, em nível ontológico e deontológico, dos adventos dessa área em seus respectivos campos de estudo.

Os questionamentos aqui apresentados em relação à interface cérebro-máquina, à inteligência artificial e, em alguma medida, ao "enhancement" cerebral extrapolam o objeto deste trabalho. Todavia, são aqui expostos de modo a demonstrar a ampla gama de possibilidades de interação entre Direito - direito penal, especialmente - e neurociências. A ligação entre esses campos do saber, como já visto no desenvolvimento da monografia, deu origem a um novo ramo do conhecimento, o neurodireito ("neurolaw"), o qual continuará a demandar, em virtude das novas descobertas proporcionadas pelo vertiginoso progresso científico e tecnológico do estudo do cérebro humano, intensa e permanente atividade de pesquisa, de natureza interdisciplinar, por parte daqueles envolvidos nas áreas afins. $\mathrm{O}$ enfrentamento dessa tarefa, destarte, se apresenta como perspectiva de futuro para o direito penal. 


\section{Conclusões}

1. A relação entre responsabilidade penal e livre-arbítrio tem origem no direito canônico, a partir do qual a avaliação sobre as intenções do agente - aqui, desde uma perspectiva moral - passou a preponderar sobre o resultado por ele produzido. Assim, a ideia de que o pecado é a falta querida e imputável ao seu autor suscitou, no direito, um questionamento já comum a outras áreas do saber, especialmente a filosofia, vale dizer: existe liberdade de vontade?

2. A problemática acerca da existência (e da possibilidade de comprovação empírica) do livre-arbítrio ganhou relevo na ciência penal com a consolidação da concepção normativa, com os aportes finalistas, da culpabilidade. Concebido como a reprovação ao autor de um fato antijurídico por haver, volitivamente (com dolo) ou sem o cuidado exigido (com culpa), praticado uma conduta contrária ao Direito, quando podia ter agido de outra forma, tal conceito tem como pressuposto existencial a possibilidade de autodeterminação (liberdade de vontade) do agente.

3. A inviabilidade da comprovação empírica da liberdade de vontade do ser humano e a indemonstrabilidade da possibilidade de o agente ter agido de outro modo, em conformidade com a norma, na situação concreta em que se encontrava, revelaram a insuficiência teórica da concepção finalista da culpabilidade. Somadas à crítica de que o juízo de reprovação carregaria consigo uma indesejável carga moral, as dúvidas em torno da existência de livre-arbítrio conduziram a uma crise no conceito normativo de culpabilidade.

4. A crise da culpabilidade normativa suscitou na doutrina penal uma série de proposições com vistas a elaborar uma estrutura de responsabilização penal de caráter pessoal que solucionasse os problemas identificados a partir das críticas formuladas. No que diz respeito à posição do livre-arbítrio no modelo de imputação, tais propostas podem ser classificadas em duas grades linhas teóricas: $(i)$ a linha baseada na afirmação do livrearbítrio, que o encara como uma realidade concreta, sustenta sua existência e formula modelos de culpabilidade nele assentados; e (ii) a linha não baseada na afirmação do livrearbítrio, que elabora estruturas de responsabilização penal indiferentes à demonstrabilidade empírica do fenômeno, seja por considerá-lo uma presunção necessária para o direito penal, seja por assentar a punição em outros fundamentos. 
5. Os debates contemporâneos acerca do livre-arbítrio são orientados não por um, mas por dois questionamentos: o "questionamento determinista"; e o "questionamento compatibilista". O "questionamento determinista" busca revelar se é verdadeira a tese de que em qualquer tempo - pelo menos até o "momento derradeiro" - o universo tem um único e exclusivo futuro fisicamente possível. O "questionamento compatibilista", por sua vez, procura desvendar se é possível haver liberdade de vontade em um universo determinista.

6. As pesquisas em neurociência, em seu atual estágio de desenvolvimento, não impactam significativamente o debate filosófico em torno da liberdade de vontade, por não contribuírem na solução tanto do "questionamento determinista", quanto do "questionamento compatibilista" - a neurociência, para começar, não é capaz de indicar que vivemos em um universo determinista. $\mathrm{O}$ estado da arte da discussão filosófica sobre o livre-arbítrio, assim, continua no mesmo nível de anteriormente ao advento da neurociência, vale dizer: nossa noção intuitiva de que, de alguma forma, estamos no comando de nossas próprias ações permanece em uma encruzilhada científica, onde, em um flanco, estão os partidários da física clássica e, de outro, ficam os defensores da física quântica de escala atômica - sendo que nenhum deles é capaz de apresentar uma resposta satisfatória acerca da liberdade de vontade.

7. O quadro que a neurociência até o momento pôde produzir, com relação aos processos de formação da vontade, é um de mecanismos infundidos com processos indeterminísticos ou estocásticos (aleatórios ou probabilísticos): se um neurônio irá disparar ou não, que padrão de potenciais de ação ele gerará, ou quantas vesículas sinápticas serão liberadas, tudo isso tem sido caracterizado como fenômenos estocásticos nos melhores modelos disponíveis atualmente. Contudo, se a imprevisibilidade que se constata nos experimentos é realmente devida a processos indeterminísticos, ou se é causada por processos determinísticos complexos que estão além de nossa atual compreensão, são questões que a neurociência não é capaz resolver - pelo menos por enquanto.

8. Os resultados das pesquisas neurocientíficas acerca do livre-arbítrio, apesar de pouco terem impactado o cerne do problema, produziram ao menos um aporte significativo à questão: ao compreender os processos mentais não como entes abstratos, mas como decorrentes dos processos cerebrais, a neurociência, valendo-se do intenso desenvolvimento das técnicas de leitura da atividade cerebral, passou a identificar, de 
maneira sem precedentes, disfunções cerebrais com repercussão direta no comportamento humano, que até então não podiam ser identificadas. Essa contribuição impacta diretamente as áreas do conhecimento para as quais o livre-arbítrio é objeto de estudo, porque, apesar de não poder resolver o problema de se temos ou não, efetivamente, tal aptidão, permite que se identifique situações em que, certamente, a vontade não era livre ou, ao menos, não fora formada normalmente, seja por conta de desequilíbrios neurofisiológicos, seja em razão desajustes na anatomia cerebral etc.

9. A neurociência já se revela como uma realidade em diversos tribunais, notadamente em países estrangeiros, como os Estados Unidos da América, o Reino Unido e a Índia, onde a leitura da atividade cerebral (especificamente, o "neuroimageamento") tem sido utilizada como prova técnica no processo penal para várias finalidades, dentre as quais: $(i)$ demonstrar que o réu tinha uma condição mental que o tornava inapto para ser interrogado perante o Juízo; (ii) indicar que o acusado tinha conhecimento experimental (ou memória) da perpetração do crime; e, especialmente, para (iii) arguir a mitigação da culpabilidade do autor do injusto penal, seja em razão de anormalidades cerebrais, seja por conta do desenvolvimento incompleto do sistema nervoso central, no caso de adolescentes. Contudo, apesar da utilização cada vez mais frequente de exames neurológicos como prova técnica - muitas vezes aliada ao depoimento de neurocientistas, na condição de peritos ou assistentes técnicos -, ainda não está claro, no atual estágio de desenvolvimento científico, qual o nível de confiabilidade dessa espécie de elemento de informação na consecução daquelas finalidades.

10. A proposta teórica de um grupo de neurocientistas estadunidenses de extinção da inimputabilidade da estrutura de responsabilização criminal e consequente edificação de um modelo de punição voltado à reabilitação do infrator por meio da intervenção cerebral direta e indireta ainda não está suficientemente estruturada a ponto de ser detidamente debatida pela doutrina penal, pois fundamenta-se em pressuposto extremamente inseguro, carente de mínima base empírica, a saber: a consideração de que toda conduta criminosa é causada por disfunções cerebrais. Além disso, a aplicação, na prática forense, de técnicas de "enhancement" - melhora, aperfeiçoamento ou fortalecimento - das funções mentais e intelectuais enquanto pena, voltada a reabilitação do infrator, se mostra, no presente, absolutamente temerária, em razão da parca análise doutrinária e da ainda limitada discussão social a respeito. 
11. Conquanto sejam fascinantes as projeções da neurociência cognitiva - vale dizer, demonstrar objetivamente, por meio de leitura da atividade cerebral em tempo real, como a vontade foi formada, conduzindo o processo da tomada de decisão e resultando na realização da ação -, os resultados de suas pesquisas ainda são muito incipientes, seja porque as técnicas utilizadas são relativamente rudimentares, seja porquanto muitas das experiências levadas a efeito são direcionadas, pretendendo substituir uma situação real de resposta livre por conjunturas construídas em um ambiente controlado. Assim, no atual estágio de seu desenvolvimento, a neurociência não representa o fim da culpabilidade na estrutura de responsabilização penal.

12. A neurociência do presente já tem aportado conhecimentos suficientes a enaltecer uma visão preventiva do direito penal. Com relação à prevenção geral, os robustos resultados de pesquisas envolvendo os processos de formação da vontade no cérebro humano, que demonstram que fatores ambientais - isto é, estímulos externos ao indivíduo - têm influência fundamental em nossos comportamentos, reforçam sobremaneira as teses de que a proibição penal: (i) tem o condão de infundir temor a possíveis delinquentes, sendo apta a afastá-los da prática delitiva (prevenção geral negativa); e (ii) reforça a consciência jurídica de cumprimento da norma, com efeitos de aprendizagem, confiança e pacificação social (prevenção geral positiva). No que se refere à prevenção especial, a neurociência, por meio de suas técnicas, ao possibilitar uma compreensão mais apurada dos mecanismos cerebrais relacionados a determinados tipos de comportamento antissocial - como o agressivo ou violento -, tem logrado, pouco a pouco, mas de forma promissora, associar certas disfunções neuronais a algumas práticas definidas como crime, possibilitando, nesses casos, identificar as causas da atividade delituosa e, assim, atuar sobre o autor do injusto penal para evitar que volte a delinquir no futuro.

13. Em suma, à parte todas as possíveis (e promissoras) contribuições que as pesquisas neurocientíficas podem oferecer ao sistema de justiça criminal a médio e longo prazo, dois são os aportes da neurociência que já podem impactar, de forma imediata, o direito penal: $(i)$ os relacionados à identificação de disfunções cerebrais que repercutem diretamente no comportamento humano, acarretando ações ou omissões em que a vontade do indivíduo certamente não é livre ou, ao menos, não é formada dentro de padrões de normalidade cognitiva - ampliando, assim, o espectro da inimputabilidade e conferindo, 
ainda, maior embasamento teórico às propostas de prevenção especial, como, por exemplo, o tratamento terapêutico enquanto modalidade de sanção penal; e (ii) aqueles relacionados à demonstração da influência do ambiente - especialmente, fatores culturais, morais e jurídicos - na formação da personalidade e na realização das condutas humanas corroborando as teses de prevenção geral negativa e positiva.

14. Por fim, da análise da compatibilidade entre as principais formulações alternativas à culpabilidade finalista existentes atualmente e os postulados neurocientíficos, conclui-se que as propostas teóricas mais adequadas aos conhecimentos em neurociência são as de Claus RoXIN e Winfried HASSEMER, na medida em que ambos não fundamentam seu conceito de culpabilidade no livre-arbítrio (ou no "poder agir de outro modo"), bem ainda reconhecem a eficácia das finalidades preventivo-gerais da pena. Assim, pode-se apontar como perspectiva teórica para o futuro da culpabilidade a emergência (e prevalência) de modelos de responsabilização próximos aos formulados por esses autores, ao menos no que diz respeito às seguintes características: não fundamentação da punição no "poder agir de outro modo" ou, de maneira mediata, no livre-arbítrio; e presença de critérios de imposição e dosimetria da pena que levem em consideração suas finalidades preventivas. 


\section{Bibliografia}

Agostinho, Santo. Os pensadores, v. 6. São Paulo: Abril Cultural, 1980.

Alemanha. Código Penal Alemán - del 15 de mayo de 1871, con la última reforma del 31 de enero de 1998. Trad.: Claudia López Diaz. Bogotá: Universidad Externado de Colombia, 1999.

ALLER, Germán. Estudio preliminar. In: BINDING, Karl. La culpabilidad en derecho penal. Montevidéu e Buenos Aires: Editorial B de F, 2009.

Amaral, Cláudio do Prado. Bases teóricas da ciência penal contemporânea: dogmática, missão do direito penal e política criminal na sociedade de risco. São Paulo: IBCCRIM, 2007.

ARISTÓTELES. Ética à Nicômaco. $3^{\mathrm{a}}$ edição. São Paulo: Editora Martin Claret, 2001.

BAtista, Nilo. Cem anos de reprovação. In: Passagens - Revista Internacional de História Política e Cultura Jurídica, v. 1, nº 1, janeiro-junho de 2009. Disponível em: http://www.historia.uff.br/revistapassagens/artigos/v1n1a1.pdf. Acesso em: 06/06/2014.

BATTS, Shelley. Brain lesions and their implications in criminal responsability. In:

Behavioral Sciences \& the Law (special issue: The Neuroscience and Psychology of Moral Decision Making and the Law), v. 27, n. 2, março e abril de 2009, pp. 261 a 272.

BAUMEISTER, Roy F. Evil: Inside human violence and cruelty. Nova Iorque: Freeman, 1997.

. HeAtherton, Todd F. Tice, Dianne M. Losing control: how and why people fail at self-regulation. San Diego: Academic Press, 1994.

Masicampo, E. J. DeWall, C. Nathan. Prosocial benefits of feeling free: disbelief in free will increases aggression and reduces helpfulness. In: Personality and Social Psychology Bulletin, v. 35, n. 2, pp. 260 a 268, fevereiro de 2009.

BINDING, Karl. La culpabilidad en derecho penal. Montevidéu e Buenos Aires: Editorial B de F, 2009. 
BRANDÃo, Cláudio. Culpabilidade: sua análise na dogmática e no direito penal brasileiro. In: Revista da Associação Brasileira de Professores de Ciências Penais, $\mathrm{n}^{\circ}$ 1, julhodezembro de 2004. São Paulo: Editora Revista dos Tribunais, 2004.

Brasil. Código Penal (Decreto-lei $n^{\circ} 2.848$ de 7 de dezembro de 1940). Rio de Janeiro, 7 de dezembro de 1940. Disponível em:

http://www6.senado.gov.br/legislacao/ListaPublicacoes.action?id=102343 (texto original), http://www.diariodasleis.com.br/busca/exibelink.php?numlink=1-96-15-1940-12-07-2848CP (exposição de motivos) e http://www.planalto.gov.br/ccivil_03/decretolei/Del2848compilado.htm (texto atual). Acessado em: 05/03/2.015.

Brunoni, Nivaldo. Princípio da culpabilidade: considerações - fundamento, teoria e consequências. Curitiba: Juruá Editora, 2010.

Buckholtz, Joshua W. Treadway, Michael T. Cowan, Ronald L. Woodward, Neil D. et al. Mesolimbic dopamine reward system hypersensitivity in individuals with psychopathic traits. In: Nature Neuroscience, v. 13, março de 2010, pp. 419 a 421.

BURNS, Jeffrey M. SWERDLOw, Russell H. Right orbitofrontal tumor with pedophilia symptom and constructional apraxia sign. In: Archives of Neurology, v. 60, n. 3, março de 2003, pp. 437 a 440.

Busato, Paulo César. Apontamentos sobre o dilema da culpabilidade penal. In: Revista Liberdades, n. 8, setembro-dezembro de 2011, pp. 45 a 87.

Bustos RamíreZ, Juan. Introducción al derecho penal. $3^{\mathrm{a}}$ ed. Bogotá: Editorial Temis S. A., 2005.

Hermozabal MalaréE, Hernán. Lecciones de derecho penal, volumen II. Madri: Editorial Trotta, 1999.

CAmargo, Antonio Luís Chaves. Culpabilidade e reprovação penal. Tese para o concurso de titularidade. São Paulo: Faculdade de Direito da Universidade de São Paulo, 1993.

Sistema de penas, dogmática jurídico-penal e política criminal. Tese para o concurso de titularidade. São Paulo: Faculdade de Direito da Universidade de São Paulo, 2001. 
CAMPBEll, Colin. EASTMAn, Nigel. The neurobiology of violence: science and law. In: Richmond, Sarah D. REES, Geraint. EDWARdS, Sarah J. L. I Know What You're Thinking: Brain imaging and mental privacy. Nova Iorque: Oxford University Press, 2012. Pp. 139 a 152.

CANARIS, Claus-Wilhelm. Pensamento sistemático e conceito de sistema na ciência do direito. Lisboa: Fundação Calouste Gulbenkian, 1989.

CAnCIO Meliá, Manuel. Psicopatía y derecho penal: algunas consideraciones introductorias. In: DEMETRIO CRESPO, Eduardo (dir.). Neurociencias y derecho penal nuevas perspectivas en el ámbito de la culpabilidad y tratamiento jurídico-penal de la peligrosidad. Montevidéu e Buenos Aires: Editorial B de F, 2013. Pp. 529 a 545.

CARbonell Mateu, Juan Carlos. Derecho penal: concepto y principios constitucionales. $3^{\text {a }}$ ed. Valência: Tirant lo Blanch, 1999.

Carmena, Jose M. Lebedev, Mikhail A. Crist, Roy E. O'Doherty, Joseph E. SAntucci, David M. Dimitrov, Dragan F. PATIL, Parag G. Henriquez, Craig S. NiColelis, Miguel A. L. Learning to control a brain-machine interface for reaching and grasping by primates. In: PLoS Biology, v. 1, n. 2, novembro de 2003, pp. 193 a 208.

CARVER, C. S. SCHEIER, M. F. Attention and self-regulation: a control-therapy approach to human behavior. Berlim: Springer-Verlag, 1981.

Caspi, A. McClay, J. Moffitt, T. E. Mill, J. Martin, J. Craig, I. W. Taylor, A. Poulton, R. Role of genotype in the cycle of violence in maltreated children. In: Science Magazine, v. 297, n. 5.582, 2 de agosto de 2002, pp. 851 a 854.

. Sugden, K. Moffitt, T. E. TAylor, A. Craig, I. W. McClay, J. Mill, J.

Martin, J. Braithwaite, A. Poulton, R. Influence of life stress on depression: moderation by a polymorphism in the 5-HTT gene. In: Science Magazine, v. 301, n. 5.631, 18 de julho de 2003, pp. 386 a 389.

Moffitt, T. E. Cannon, M. McClay, J. Murray, R. Harrington, H. Taylor, A. Arseneault, L. Willians, B. Braithwaite, A. Poulton, R. Craig, I. W. Moderation of the effect of adolescent-onset cannabis use on adult psychosis by a functional polymorphism in the catechol-O-methyltransferase gene: longitudinal evidence 
of a gene X environment interaction. In: Biological Psychiatry, v. 57, n. 10, 15 de maio de 2005, pp. 1.117 a 1.127.

CEREZO MIR, José. Derecho penal: parte general. São Paulo: Editora Revista dos Tribunais; Lima (Peru): ARA Editores, 2007.

Ontologismo e normativismo na teoria finalista. In: Revista da Associação Brasileira de Professores de Ciências Penais, $n^{\circ}$ 0, pp. 9 a 23, janeiro-julho de 2004. São Paulo: Editora Revista dos Tribunais, 2004.

Chiu, P. King-Casas, B. Cinciripini, P. Versace, F. Eagleman, D. Lisinski, J. LINDSEY, L. LACONTE, S. Real-time fMRI modulation of craving and control brain states in chronic smokers. In: Resumo apresentado em "39th Annual Meeting of Society for Neuroscience (SfN)", Chicago, 2009.

CHOPRA, Samir. White, Laurence. Artificial agents - personhood in law and philosophy. In: JONES, Owen D. ScHALl, Jeffrey D. SHEN, Francis X. Law and neuroscience. Frederick: Wolters Kluwer Law \& Busines, 2014. Pp. 701 a 709.

CHURCH, Dominique J. Neuroscience in the Courtroom: An International Concern. In: William \& Mary Law Review, v. 53, n. 5, 2012, pp. 1.824 a 1.854. Disponível em: http://scholarship.law.wm.edu/wmlr/vol53/iss5/8. Acesso em: 02/03/2.015.

CÓRDOBA, Fernando Jorge. La capacidad de motivación y la imputación de culpabilidad. In: Cuadernos de doctrina y jurisprudencia penal, v. 9, n. 15, 2003, pp. 459 a 476.

DeISSEROTH, Karl. Optogenetics. In: Nature Methods - Advance Online Publication, publicado em 20 de dezembro de 2010, pp. 1 a 4. Disponível em: http://web.stanford.edu/group/dlab/media/papers/deisserothnature2010.pdf. Acesso em: $11 / 03 / 2.015$.

DEMETRIO CRESPO, Eduardo. "Compatibilismo humanista": una propuesta de conciliación entre neurociencias y derecho penal. In: DEMETRIO CRESPO, Eduardo (dir.). Neurociencias y derecho penal - nuevas perspectivas en el ámbito de la culpabilidad y tratamiento jurídico-penal de la peligrosidad. Montevidéu e Buenos Aires: Editorial B de F, 2013 [1]. Pp. 17 a 42. 
Presentación. In: DEMETRIO CRESPO, Eduardo (dir.). Neurociencias y derecho penal - nuevas perspectivas en el ámbito de la culpabilidad y tratamiento jurídico-penal de la peligrosidad. Montevidéu e Buenos Aires: Editorial B de F, 2013 [2]. Pp. XV a XVIII.

DILMAN, Ilham. Free will: an historical and philosophical introduction. Londres e Nova Iorque: Routledge, 2001.

Dodd, M. Leann. Klos, Kevin J. Bower, James H. GedA, Yonas E. JosePhS, Keith A. AHLSKOG, J. Eric. Pathological gambling caused by drugs used to treat Parkinson disease. In: Archives of neurology, v. 62, n. 9, setembro de 2005, pp. 1.377 a 1.381.

Dreher, Jean-Claude. Kohn, Philip. Kolachana, Bhaskar. Weinberger, Daniel R. BERMAN, Karen Faith. Variation in dopamine genes influences responsivity of the human reward system. In: Proceedings of the National Academy of Sciences of the United States of America, v. 106, n. 2, janeiro de 2009, pp. 617 a 622.

Dworkin, Gerald. The Theory and Practice of Autonomy. Cambridge: Cambridge University Press, 1988.

EAGLEMAN, David. Incógnito - as vidas secretas do cérebro. Trad.: Ryta Vinagre. Rio de Janeiro: Rocco, 2012.

ENGISCH, Karl. La teoría de la libertad de la voluntad en la actual doctrina filosófica del derecho penal. Trad.: José Luis Guzman Dalbora. Montevidéu e Buenos Aires: Editorial B de F, 2008.

FEIJOO SÁNCHEZ, Bernardo. Culpabilidad jurídico-penal y neurociencias. In: DEMETRIO CRESPO, Eduardo (dir.). Neurociencias y derecho penal - nuevas perspectivas en el ámbito de la culpabilidad y tratamiento jurídico-penal de la peligrosidad. Montevidéu e Buenos Aires: Editorial B de F, 2013. Pp. 269 a 297.

FERRI, Enrico. Principios de derecho criminal. Madri: Editorial Reus, 1933.

Fischer, John Martin. Kane, Robert. Pereboom, Derk. VARgAS, Manuel. Four views on free will. Malden, MA (EUA): Blackwell Publishing, 2010.

FRANK, Reinhard. Sobre la estructura del concepto de culpabilidad. Montevidéu e Buenos Aires: Editorial B de F, 2002. 
FREUDENTHAL, Berthold. Culpabilidad y reproche en el derecho penal. Montevidéu e Buenos Aires: Editorial B de F, 2003.

FUNDER, David C. BLOCK, Jack. The role of ego-control, ego-resiliency, and IQ in delay of gratification in adolescence. In: Journal of Personality and Social Psychology, v. 57, n. 6, dezembro de 1989, pp. 1.041 a 1.050.

Funder, David C. Block, Jeanne H. Block, Jack. Delay of gratification: Some longitudinal personality correlates. In: Journal of Personality and Social Psychology, v. 44, n. 6, junho de 1983, pp. 1.198 a 1.213.

Gailliot, Matthew T. Baumeister, Roy F. DeWall, C. Nathan. Maner, Jon K. Plant, E. Ashby. Tice, Diane M. Brewer, Lauren E. SchmeICHEL, Brandon J. Self-control relies on glucose as a limited energy source: willpower is more than a metaphor. In: Journal of Personality and Social Psychology, v. 92, n. 2, pp. 325 a 336, 2007.

GaZZANigA, Michael S. Who's in charge? Free will and the science of the brain. Nova Iorque: Ecco (HarperCollins Publishers), 2011.

GILISSEN, John. Introdução histórica ao direito. $5^{\mathrm{a}}$ ed. Lisboa: Fundação Calouste Gulbenkian, 2007.

GimbernAt OrdeIG, Enrique. ¿Tiene un futuro la dogmática juridicopenal? In: Gimbernat Ordeig, Enrique. Estudios de derecho penal. $3^{a}$ ed. Madri: Tecnos, 1990.

GOLDSCHMIDT, James. La concepción normativa de la culpabilidad. Montevidéu e Buenos Aires: Editorial B de F, 2002.

GotTFREDSON, M. R. HiRsCHI, T. A general theory of crime. Stanford: Stanford University Press, 1990.

GRECO, Luís. Introdução à dogmática funcionalista do delito. In: Notícia do Direito Brasileiro, n. 7, pp. 307 a 362. Brasília: Editora UnB, 2000.

GreEne, Joshua. COHEN, Jonathan. For the law, neuroscience changes nothing and everything. In: Philosophical Transactions of the Royal Society of London, Series B, Biological Sciences, v. 359, n. 1.546, novembro de 2004, pp. 1.775 a 1.785. 
HANSON, R. Karl. MORTON-BOURGON, Kelly E. The characteristics of persistent sexual offenders: a meta-analysis of recidivism studies. In: Journal of Consulting and Clinical Psychology, v. 73, n. 6, dezembro de 2005, pp. 1.154 a 1.163.

Hare, Todd A. CAMerer, Colin F. RAngel, Antonio. Self-control in decision-making involves modulation of the vmPFC valuation system. In: Science Magazine, v. 324, n. $5.927,1^{\circ}$ de maio de 2009, pp. 646 a 648.

HARTMANN, Nicolai. Ética. Madri: Ediciones Encuentro, 2011.

HASSEMER, Winfried. Neurociencias y culpabilidad en derecho penal. In: InDret - Revista para el análisis del derecho, n. 2/2011, Barcelona, abril de 2011.

Persona, mundo e responsabilidad: bases para una teoría de la imputación en derecho penal. Trad.: Francisco Muñoz Conde e María del Mar Díaz Pita. Bogotá: Editorial Temis, 1999.

Prevención general y aplicación de la pena. In: NAUCKE, Wolfgang. HASSEMER, Winfried. LÜDERSSEN, Klaus. Principales problemas de la prevención general. Montevidéu e Buenos Aires: Editorial B de F, 2004. Pp. 45 a 82.

Herman, C. Peter. Polivy, Janet. Anxiety, restraint and eating behavior. In: Journal of Abnormal Psychology, v. 84, n. 6, dezembro de 1975, pp. 666 a 672.

HIRSCH, Hans Joachim. Acerca de los errores y extravíos en la teoría contemporánea de la culpabilidad. In: Anuario de derecho penal y ciencias penales, v. 60, janeiro-dezembro de 2007, pp. 11 a 38. Madri: Boletín Oficial del Estado, 2007.

HOYER, Andreas. Ciencia del derecho penal y nacionalsocialismo. In: Revista de Derecho Penal, Buenos Aires, n. 1, pp. 517 a 540, 2009.

JAKOBS, Günther. Culpabilidad jurídico-penal y "libre albedrío". In: FEIJOO SÁNCHEZ, Bernardo José (coord.). Derecho penal de la culpabilidad y neurociencias. Navarra: Civitas, 2012.

Derecho penal - parte general: fundamentos y teoría de la imputación. $2^{\mathrm{a}} \mathrm{ed}$. Madri: Marcial Pons, 1997. 
El principio de culpabilidad. In: Anuario de derecho penal y ciencias

penales, Madri, v. 45, n. 3, pp. 1051 a 1083, setembro-dezembro de 1992.

Indivíduo e pessoa: imputação jurídico-penal e os resultados da moderna neurociência. Trad.: Eduardo Saad-Diniz. In: SAAD-DINIZ, Eduardo. POLAINO-ORTS, Miguel (orgs.). Teoria da pena, bem jurídico e imputação. São Paulo: LiberArs, 2012. Pp. 23 a 40.

JESCHECK, Hans-Heinrich. Evolición del concepto jurídico penal de culpabilidad en Alemania y Austria. Trad.: Patrícia Esquinas Valverde. In: Revista Electrónica de Ciencia Penal y Criminologia, $\mathrm{n}^{\circ}$ 5, 2003. Disponível em: http://criminet.ugr.es/recpc/05/recpc0501.pdf. Acesso em: 22/05/ 2014.

Tratado de derecho penal - parte general. Granada: Editorial Comares, 2002.

JiMÉNEZ SEGADO, Carmelo. Carl Schmitt y las ideas penales de la Escuela de Kiel. In: Anuario de derecho penal y ciencias penales, Madri, v. 62, pp. 451 a 482, janeirodezembro de 2009.

JuCKel, Georg. Schlagenhauf, Florian. Kosowski, Michael. WÜstenberg, Torsten et al. Dysfunction of ventral striatal reward prediction in schizophrenia. In: NeuroImage, v. 29, n. 2, janeiro de 2006, pp. 409 a 416.

KANE, Robert. Introduction: the contours of contemporary free will. In: KANE, Robert (ed.). The Oxford handbook of free will. Nova Iorque: Oxford University Press, 2002.

Kelly, E. L. Conley, J. J. Personality and compatibility: A prospective analysis of marital stability and marital satisfaction. In: Journal of Personality and Social Psychology, v. 52, janeiro de 1987, pp. 27 a 40.

KenNeDy, Harry G. GRUBIN, Donald H. Hot-headed or impulsive? In: British Journal of Addiction, v. 85, n. 5, maio de 1990, pp. 639 a 643.

KINDHÄUSER, Urs. Culpabilidad jurídico-penal en el Estado Democrático de Derecho. In: KINDHÄUSER, Urs. MAÑALICH, Juan Pablo. Pena y culpabilidad en el Estado democrático de derecho. Montevidéu e Buenos Aires: Editorial B de F, 2011 [1]. 
La fidelidad al derecho como categoría de la culpabilidad. In: KINDHÄUSER, Urs.

MaÑAliCH, Juan Pablo. Pena y culpabilidad en el Estado democrático de derecho.

Montevidéu e Buenos Aires: Editorial B de F, 2011 [2].

KuHN, Thomas S. A estrutura das revoluções científicas. $2^{\mathrm{a}}$ ed. São Paulo: Editora Perspectiva, 1978.

LALANDE, André. Vocabulário técnico e crítico da filosofia. São Paulo: Martins Fontes, 1993.

LARENZ, Karl. Metodologia da ciência do direito. Trad.: José Lamego. $3^{\text {a }}$ ed. Lisboa:

Fundação Calouste Gulbenkian, 1991.

LENT, Roberto. Cem bilhões de neurônios? Conceitos fundamentais de neurociência. $2^{\mathrm{a}}$ ed. São Paulo: Atheneu, 2010.

LESSA, Pedro. O determinismo psychico e a imputabilidade e a responsabilidade criminaes

- Memoria apresentada ao Congresso Scientífico latino-americano. São Paulo:

Typographia Duprat, 1905.

LiBET, Benjamin. Do we have free will?. In: Journal of Consciousness Studies, v. 6, n. 8-9, 1999, pp. 47 a 57.

LiszT, Franz von. Tratado de direito penal allemão, tomo I. Trad.: José Higino Duarte Pereira. Rio de Janeiro: F. Briguiet \& C. Editores, 1899.

Lombroso, Cesare. O homem delinquente. Trad.: Sebastião José Roque. São Paulo, Ícone Editora, 2007.

LUZÓN PEÑA, Diego-Manuel. Libertad, culpabilidad y neurociencias. In: DEMETRIO

CRESPO, Eduardo (dir.). Neurociencias y derecho penal - nuevas perspectivas en el ámbito de la culpabilidad y tratamiento jurídico-penal de la peligrosidad. Montevidéu e Buenos Aires: Editorial B de F, 2013. Pp. 341 a 401.

Libertad, culpabilidad y neurociencias. In: InDret - Revista para el análisis del derecho, no 3/2012. Barcelona: julho de 2012. 
Machado, Fábio Guedes de Paula. Culpabilidade no direito penal. São Paulo: Editora Quartier Latin, 2010.

MaÑALICH, Juan Pablo. Determinismo, autonomía y responsabilidad penal. In: KINDHÄUSER, Urs. MAÑALICH, Juan Pablo. Pena y culpabilidad en el Estado democrático de derecho. Montevidéu e Buenos Aires: Editorial B de F, 2011. Pp. 181 a 210.

MARTIN, Leonard L. TESSER, Abraham. Towards a motivational and structural theory of ruminative thought. In: UlEMAN, James S. BARGH, John A. (eds.). Unintended thought. Nova Iorque: Guilford Press, 1989.

MARTIN-SOELCH, Chantal. Is depression associated with dysfunction of the central reward system? In: Biochemical Society Transactions, v. 37, 2009, pp. 313 a 317.

MeLE, Alfred R. Autonomy, self-control, and weakness of will. In: KANE, Robert (ed.). The Oxford handbook of free will. Nova Iorque: Oxford University Press, 2002.

Mendez, Mario F. Chen, Andrew K. Shapira, Jill S. Miller, Bruce L. Acquired sociopathy and frontotemporal dementia. In: Dementia and geriatric cognitive disorders, v. 20, n. 2-3, agosto de 2005, pp. 99 a 104.

MERKEL, Reinhard. Novedosas intervenciones del cerebro: mejora de la condición humana mental y límites en el Derecho Penal. In: Revista de Derecho Penal, Buenos Aires, n. 1, pp. 41 a $78,2011$.

MeZGER, Edmund. Derecho penal: parte general. Buenos Aires: Editorial Bibliografica Argentina, 1958.

La culpabilidad en el moderno derecho penal. Trad.: José Maria Navarrete.

Valladolid: Publicaciones de los seminarios de la Facultad de Derecho de la Universidad de Valladolid, v. 14, 1956.

Tratado de derecho penal, tomo II. Madri: Editorial Revista de Derecho Privado, 1957.

MiR PuIG, Santiago. Introducción a las bases del derecho penal. $2^{\mathrm{a}}$ ed. Montevidéu e Buenos Aires: Editorial B de F, 2003. 
Mommsen, Theodoro. Derecho penal romano, tomo I. Madri: La España Moderna, 1905.

MonYer, Hannah. RÖSLER, Frank. Roth, Gerhard. SCHEICH, Henning. SINGER, Wolf.

Elger, Christian E. Friederici, Angela D. Koch, Christof. Luhmann, Heiko.

Malsburg, Christoph von der. Menzel, Randolf. Das Manifest - Elfführende

Neurowissenschaftler über Gegenwart und Zukunft der Hirnforschung. In: Gehirn \& Geist, v. 6 , ano 2004 , pp. 30 a 37.

Morse, Stephen J. Newsome, Willian T. Criminal responsibility, criminal competence, and prediction of criminal behavior. In: Morse, Stephen J. RoskIES, Adina L. A primer on criminal law and neuroscience: a contribution of the Law and Neuroscience Project, supported by the MacArthur Foundation. Nova Iorque: Oxford University Press, 2013.

MuÑoz CONDE, Francisco. Introducción al derecho penal. Montevidéu e Buenos Aires: Editorial B de F, 2001.

Teoría general del delito. $4^{\mathrm{a}}$ ed. Valência: Tirant lo Blanch, 2007.

Muraven, Mark. Tice, Dianne M. BAuMEISTER, Roy F. Self-control as limited resource: regulatory depletion patterns. In: Journal of personality and social psychology, v. 74, n. 3, março de 1998, pp. 774 a 789.

NiCOLELIS, Miguel Angelo Laporta. Actions from thoughts. In: Nature, v. 409, 18 de janeiro de 2001, pp. 403 a 407.

Novoa Monreal, Eduardo. Causalismo y finalismo en derecho penal. $2^{\mathrm{a}}$ ed. Bogotá: Editorial Temis Librería, 1982.

PAtiL, Parag G. TURnER, Dennis A. The development of brain-machine interface neuroprosthetic devices. In: Neurotherapeutics: The Journal of the American Society for Experimental NeuroTherapeutics, v. 5, janeiro de 2008, pp. 137 a 146.

PÉREZ MANZANO, Mercedes. Culpabilidad y prevención: las teorías de la prevención general positiva en la fundamentación de la imputación subjetiva y de la pena. Madri: Ediciones de la Universidad Autónoma de Madrid, 1986.

El tiempo de la conciencia y la libertad de decisión: bases para una reflexión sobre neurociencia y responsabilidad penal. In: DEMETRIO CRESPO, Eduardo (dir.). 
Neurociencias y derecho penal - nuevas perspectivas en el ámbito de la culpabilidad y tratamiento jurídico-penal de la peligrosidad. Montevidéu e Buenos Aires: Editorial B de F, 2013. Pp. 105 a 135.

. Fundamento y fines del Derecho penal. Una revisión a la luz de las aportaciones de la neurociencia. In: InDret - Revista para el análisis del derecho, n. 2/2011, Barcelona, abril de 2011.

PINTO, José Marcelino de Rezende. A teoria da ação comunicativa de Jürgen

Habermas: conceitos básicos e possibilidades de aplicação à administração escolar. In: Paidéia (Ribeirão Preto), n. 8-9, pp. 77 a 96, fevereiro-agosto de 1995. Disponível em: http://www.scielo.br/pdf/paideia/n8-9/07.pdf. Acesso em: 13/07/2014.

Poli, Roberto. Nicolai Hartmann. In: ZALTA, Edward N. (ed.). The Stanford Encyclopedia of Philosophy, winter 2014 edition. Disponível em: http://plato.stanford.edu/archives/win2014/entries/nicolai-hartmann/. Acesso em: 07/01/ 2015.

PRADO, Luiz Regis. Curso de direito penal brasileiro, volume 1: parte geral. $10^{\mathrm{a}}$ ed. São Paulo: Editora Revista dos Tribunais, 2010.

RoBinson, Howard. Dualism. In: ZaLta, Edward N. (ed.). The Stanford Encyclopedia of Philosophy, winter 2012 edition. Disponível em:

http://plato.stanford.edu/archives/win2012/entries/dualism/. Acesso em: 16/01/ 2015.

RodríGUEZ, Víctor Gabriel. Fundamentos de direito penal brasileiro. São Paulo: Atlas, 2010.

Livre-arbítrio e direito penal: revisão frente aos aportes da neurociência e à evolução dogmática. Tese para o concurso de livre-docência. Ribeirão Preto: Faculdade de Direito de Ribeirão Preto da Universidade de São Paulo, 2014.

Tutela penal da intimidade: perspectivas da atuação penal na sociedade da informação. São Paulo: Atlas, 2008.

Romeo CASABOna, Carlos Maria. Consideraciones jurídicas sobre los procedimientos experimentales de mejora (enhancement) en neurociencias. In: DEMETRIO CRESPO, 
Eduardo (dir.). Neurociencias y derecho penal - nuevas perspectivas en el ámbito de la culpabilidad y tratamiento jurídico-penal de la peligrosidad. Montevidéu e Buenos Aires: Editorial B de F, 2013. Pp.161 a 183.

RosKIES, Adina. Neuroscientific challenges to free will and responsibility. In: Trends in Cognitive Sciences, v. 10, n. 9, agosto de 2006, pp. 419 a 423.

Why Libet's studies don't pose a threat to free will. In: SinNOTT-ARMSTRONG, Walter. NADEL, Lynn (eds.). Conscious will and responsibility - a tribute to Benjamin Libet. Nova Iorque: Oxford University Press, 2011 [1]. Pp. 11 a 22. . SINNOTT-ARMSTRONG, Walter. Brain images as evidence in the criminal law. In: FREEMAN, Michael (ed.). Law and neuroscience: current legal issues volume 13. Nova Iorque: Oxford University Press, 2011 [2]. Pp. 97 a 114.

Rотн, Gerhard. Delincuentes violentos: ¿seres malvados o enfermos mentales? In: DEMETRIO CRESPO, Eduardo (dir.). Neurociencias y derecho penal - nuevas perspectivas en el ámbito de la culpabilidad y tratamiento jurídico-penal de la peligrosidad. Montevidéu e Buenos Aires: Editorial B de F, 2013. Pp. 669 a 690.

. Fühlen, Denken, Handeln: Wie das Gehirn unser Verhalten steuert. Berlim: Suhrkamp Verlag, 2003.

RoXIN, Claus. "Culpabilidad" y "responsabilidad" como categorías sistemáticas jurídicopenales. In: RoxIN, Claus. Culpabilidad y prevención en derecho penal. Madri: Editorial Reus, 1981.

. Derecho penal: parte general, tomo I. Madri: Civitas, 1997. - ¿Que queda de la culpabilidad en derecho penal? In: Cuadernos de política criminal, no 30, pp. 671 a 692. Madri: Edersa, 1986.

RubIA, Francisco J. Neurociencia y libertad. In: DEMETRIO CRESPO, Eduardo (dir.). Neurociencias y derecho penal - nuevas perspectivas en el ámbito de la culpabilidad y tratamiento jurídico-penal de la peligrosidad. Montevidéu e Buenos Aires: Editorial B de F, 2013. Pp. 185 a 190. 
RuSSELl, M. A. H. Cigarette smoking: natural history of a dependence disorder. In: British Journal of Medical Psychology, v. 44, março de 1971, pp. 1 a 16.

RuSSELL, Stuart. NORVIG, Peter. Artificial intelligence - a modern approach. Englewood Cliffs: Prentice Hall, 1995.

SCARPA, Angela. RAINE, Adrian. The psychophysiology of antisocial behavior: interactions with environmental experiences. In: WALSH, A. ELLIS, L. (org.). Biosocial criminology: challenging environmentalism's supremacy. Nova Iorque: Nova Science, 2003.

SCHÜNEMANN, Bernd. Introducción al razonamiento sistemático en Derecho Penal. In: SCHÜNEMANN, Bernd (org.). El sistema moderno de derecho penal: cuestiones fundamentales. Madri: Tecnos, 1991 [1].

La culpabilidad: estado de la cuestión. In: RoXIN, Claus. JAKOBS, Günther. SCHÜNEMANN, Bernd et al. (org.). Sobre el estado de la teoría del delito. Madri: Civitas, 2000.

. La función del principio de culpabilidad en el derecho penal preventivo. In:

SCHÜNEMANN, Bernd (org.). El sistema moderno de derecho penal: cuestiones fundamentales. Madri: Tecnos, 1991 [2].

La significación del principio penal de culpabilidad en la época de la globalización. In: SCHÜNEMANN, Bernd. Obras. Buenos Aires: Rubinzal-Culzoni, 2009.

Libertad de voluntad y culpabilidad en derecho penal. In: SCHÜNEMANN, Bernd. Temas actuales y permanentes del derecho penal después del milenio. Madri: Tecnos, 2002 [1]. Pp. 24 a 48.

. Nuevas tendencias en el concepto jurídico-penal de culpabilidad. In:

SCHÜNEMANN, Bernd. Temas actuales y permanentes del derecho penal después del milenio. Madri: Tecnos, 2002 [2]. Pp. 113 a 128.

SILVA, Magali Milene. A saúde mental e a fabricação da normalidade: uma crítica aos excessos do ideal normalizador a partir das obras de Foucault e Canguilhem. In: Revista Interação em Psicologia, v. 12, n. 1, janeiro a junho de 2008, pp. 141 a 150. 
SINGER, Wolf. Keiner kann anders, als er ist. In: Frankfurter Allgemeine Zeitung, 8 de janeiro de 2004.

SMITH, Kerri. Taking aim at free will. In: Nature Magazine, v. 477, setembro de 2011, pp. 23 a 25.

SoOn, Chun Siong. Brass, Marcel. HeInZE, Hans-Jochen. HAYNES, John-Dylan.

Unconscious determinants of free decisions in the human brain. In: Nature Neuroscience, v. 11, n. 5, maio de 2008 .

STANFORD, Matthew S. BARRATT, Ernerst S. Impulsivity and the multi-impulsive personality disorder. In: Personality and Individual Differences, v. 13, n. 7, julho de 1992, pp. 831 a 834 .

Tangerino, Davi de Paiva Costa. Culpabilidade. Rio de Janeiro: Campus Elsevier, 2011.

TAVARES, Juarez. Culpabilidade: incongruência dos métodos. In: Revista Brasileira de Ciências Criminais, v. 6, n 25, outubro-dezembro de 1998. São Paulo: Editora Revista dos Tribunais, 1998.

Teorias do delito (variações e tendências). São Paulo: Editora Revista dos Tribunais, 1980.

THE Royal SocIETY. Neuroscience and the law. In: Brain waves, module 4, dezembro de 2011, pp. 01 a 35. Disponível em:

https://royalsociety.org/ /media/royal_society_content/policy/projects/brain-waves/brainwaves-4.pdf. Acesso em: 02/03/2.015.

Toledo, Francisco de Assis. Princípios básicos de direito penal. $5^{\text {a }}$ edição. São Paulo: Saraiva, 2008.

TomÁs De AQuino, São. Suma de teología, parte I. $4^{\mathrm{a}}$ ed. Madri: Biblioteca de Autores Cristianos, 2001.

TREVENA, Judy. MILLER, Jeff. Brain preparation before a voluntary action: evidence against unconscious movement initiation. In: Consciousness and cognition, v. 19, n. 1, março de 2010, pp. 447 a 456. 
Turk, David J. Heatherton, Todd F. Macrae, C. Neil. Kelley, Willian M.

GAZZANIGA, Michael S. Out of contact, out of mind: the distributed nature of the self. In: Annals of the New York Academy of Sciences, outubro de 2003, pp. 65 a 78.

VAN Gulick, Robert. Consciousness. In: Zalta, Edward N. (ed.). The Stanford Encyclopedia of Philosophy, spring 2014 edition. Disponível em: http://plato.stanford.edu/archives/spr2014/entries/consciousness/. Acesso em: 16/01/ 2015. VIVES ANTÓN, Tomás Salvador. El principio de culpabilidad. In: DíEZ RIPOLLÉS, José Luis. Romeo Casabona, Carlos María. Gracia Martín, Luis. Higuera Guimerá, Juan Felipe (eds.). La ciencia del derecho penal ante el nuevo siglo: libro homenaje al profesor doctor Don José Cerezo Mir. Madri: Tecnos, 2003. Pp. 211 a 234.

O princípio da culpabilidade. In: Revista justiça e sistema criminal: modernas tendências do sistema criminal, v. 2, nº 2, pp. 35 a 64, janeiro-junho de 2010. Curitiba: FAE Centro Universitário, 2010.

VOHS, Kathleen D. SCHOOLER, Jonathan W. The value of believing in free will: encouraging a belief in determinism increases cheating. In: Psychological Science, v. 19, n. 1, pp. 49 a 54, janeiro de 2008.

WALLACH, Wendell. From robots to techno sapiens: ethics, law and public policy in the development of robotics and neurotechnologies. In: Law, Innovation and Technology, v. 3, n. 2, dezembro de 2011, pp. 185 a 207.

WALTER, Henrik. Neurophilosophy of free will - from libertarian illusions to a concept of natural autonomy. Cambridge: MIT Press, 2009.

WEGNER, Daniel M. Precis of The illusion of conscious will. In: Behavioral and Brain Sciences, v. 27, pp. 649 a 692, outubro de 2004.

Wegner, Daniel M. PennebaKeR, James W. Handbook of mental control. Englewood Cliffs: Prentice Hall, 1993.

Welzel, Hans. A dogmática no direito penal. In: Revista de Direito Penal, Rio de Janeiro, $n^{\circ} 13$ e 14, pp. 7 a 12, janeiro-junho de 1974. São Paulo: Editora Revista dos Tribunais, 1974. 
Derecho penal - parte general. Buenos Aires: Roque Depalma Editor, 1956.

El nuevo sistema del derecho penal: una introducción a la doctrina de la acción finalista. Montevidéu e Buenos Aires: Editorial B de F, 2004.

Teoría de la acción finalista. Buenos Aires: Astrea, 1951.

Wenzlaff, Richard M. Wegner, Daniel M. RoPer, David W. Depression and mental control: the resurgence of unwanted negative thoughts. In: Journal of Personality and Social Psychology, v. 55, n. 6, dezembro de 1988, pp. 882 a 892.

Wu, Stephen S. Goodman, Marc. Neural implants and their legal implications. In: GPSolo Magazine, v. 30, n. 1, janeiro-fevereiro de 2013, pp. 68 a 71.

ZAFFARONI, Eugenio Raúl. En busca de las penas perdidas: deslegitimacion y dogmatica juridico-penal. Buenos Aires: Ediar, 1998.

SloKar, Alejandro. Alagia, Alejandro. Manual de derecho penal - parte general. Buenos Aires: Ediar, 2006. 